UNIVERSIDADE DE BRASÍLIA - UnB

INSTITUTO DE GEOCIÊNCIAS - IG

PROGRAMA DE PÓS GRADUAÇÃO EM GEOLOGIA

O SISTEMA MAGMÁTICO DO DEPÓSITO Cu-Mo TIPO PÓRFIRO PANCHO ÁRIAS, CORDILHEIRA ORIENTAL, ARGENTINA

DISSERTAÇÃO DE MESTRADO N 374

RAFAEL BELLOZUPKO STREMEL

BRASÍLIA - DF

2016 


\section{O SISTEMA MAGMÁTICO DO DEPÓSITO Cu-Mo TIPO PÓRFIRO PANCHO ÁRIAS, CORDILHEIRA ORIENTAL, ARGENTINA}

\section{RAFAEL BELLOZUPKO STREMEL}

Dissertação apresentada ao Programa de PósGraduação em Geologia do Instituto de Geociências, Universidade de Brasília, como requisito básico para obtenção do título de Mestre em Geociências, área de concentração Geologia Econômica.

\section{Orientador}

Prof. Dr. Valmir da Silva Souza

$$
\text { Co - Orientador }
$$

Prof. Dr. José Marcelo Arnósio

Banca Examinadora

Prof. Dr. Valmir da Silva Souza (IG-UnB)

Prof. Dr. Caetano Juliani (IGC-USP)

Prof. Dr. Claudinei Gouveia de Oliveira (IG-UnB)

Brasília - DF, 2016 
"There are no facts, only interpretations."

Friedrich Nietzsche 


\section{Agradecimentos}

Primeiramente agradeço a Deus por me dar a saúde e força necessárias para realizar as conquistas que obtive e que ainda obterei nessa vida. Obrigado Senhor!

Agradeço aos meus pais, Aluizio Stremel Filho e Marcilia Bellozupko Stremel, e ao meu irmão, Felipe Bellozupko Stremel, pelo amor incondicional e por todo suporte que me deram até o dia de hoje, sem vocês nada disso seria possível. Prometo dar o meu melhor para um dia poder recompensá-los da melhor maneira possível. Eu amo muito cada um de vocês!

Agradeço ao meu orientador, Prof. Dr. Valmir da Silva Souza, pela sua excelente orientação, pela incansável ajuda em diversas áreas, pela paciência nos momentos difíceis, e por ter confiado no meu trabalho ao me convidar para fazer parte deste projeto. Após quatro anos trabalhando juntos, posso afirmar que mais que um orientador, eu ganhei um grande amigo.

Agradeço ao meu co-orientador, Prof. Dr. José Marcelo Arnósio, por todo o suporte fornecido durante minha estadia na Argentina e por ter me acompanhado durante o trabalho de campo. ¡Gracias Chino!

Agradeço ao Alejandro, técnico da UNSa, por todo suporte laboratorial e por sua imensa ajuda. ¡Gracias Ale!

Agradeço as instituições Universidade de Brasília e Universidad Nacional de Salta por todo o suporte financeiro e técnico-científico. Agradeço ao CNPq pelo apoio financeiro durante a pesquisa e a CAPES pela bolsa de estudos.

Agradeço aos meus amigos geólogos Caio, Emilce, Roberto, Giuliano, Leonardo, Marco, Marina, Mara e Gabriel por toda a ajuda e apoio. Agradeço especialmente a minha amiga Jéssica Maia, por cada palavra de incentivo e por cada minuto em que gastou para me ajudar, sua presença diária foi fundamental para o resultado final obtido.

Agradeço aos meus demais parentes por sempre se preocuparem comigo e por me amarem incondicionalmente, sou abençoado por ter uma família tão grande e participativa.

Por fim, um agradecimento especial ao meu querido tio Antônio Wilson Zulai, que infelizmente nos deixou no dia 14/08/2016. Obrigado por ter sido um verdadeiro pai para mim durante esses anos, sua trajetória de vida foi linda e sua missão foi totalmente realizada. Sei que você continuará olhando por mim de um lugar muito melhor. Descanse em paz! 


\section{RESUMO}

O depósito Cu-Mo Pancho Árias localiza-se na Cordilheira Oriental dos Andes Centrais argentinos, é o membro mais antigo do complexo magmático Las Burras-Almagro-El Toro, que constituí um dos corpos ígneos terciários localizados no lineamento Calama-Olacapato-El Toro. A área hospeda quatro membros magmáticos intrusivos em um embasamento metassedimentar neoproterozoico. Esses membros são dois pórfiros andesíticos, um stock de composição quartzomonzodiorito e um sistema de diques e sills riodacíticos a traqui-andesíticos. Ocorrem corpos de brechas ligados aos pórfiros andesíticos, e ao stock. A localização no depósito, bem como as texturas e composições nos permitiram individualizar seis corpos de brechas, as quais são dos tipos polimíticas e monomíticas, em arranjo que podem ser tanto matriz como fragmento suportado. Em geral, as brechas do setor centro-nordeste hospedam a parte da mineralização em $\mathrm{Cu}$, a qual é formada por cristais de calcopirita parcialmente substituídos por covelita. Porém, a mineralização também se estende às rochas encaixantes aprisionada em vênulas e estruturas stockwork. Nessa situação, o predomínio da mineralização é em Mo e ocorre sob a forma de cristais de molibdenita associados aos veios de quartzo. A alteração hidrotermal registrada é do tipo zonal concêntrica, com o núcleo potássico migrando progressivamente para uma zona distal propilítica. A alteração fílica ocorre associada a falha NW-SE. Essas fases magmáticas são álcali-cálcicas a calcialcalinas, peraluminosas a metaluminosas, com assinatura de magmatismo do tipo I cordilheiriano, alojados em ambiente tectônico de arco vulcânico. Exibem leve fracionamento nos ETR leves em relação aos ETR pesados $\left([\mathrm{La} / \mathrm{Yb}]_{\mathrm{N}}=6-12\right)$ e discreta anomalia em $\mathrm{Eu}(\mathrm{Eu} / \mathrm{Eu} *=0,2-0,9)$. O padrão multielementar assemelha-se ao padrão de rochas da crosta superior, com anomalias negativas em $\mathrm{Nb}-\mathrm{P}-\mathrm{Ti}$ e anomalias positivas em Rb-Sm-Tb. As razões ${ }^{147} \mathrm{Sm} /{ }^{144} \mathrm{Nd}$ das fases magmáticas indicam valor entre 0,0985 e 0,1115 . As razões ${ }^{143} \mathrm{Nd} /{ }^{144} \mathrm{Nd}$ estão entre 0,512665 e 0,512738 , valores que geram $\mathrm{e}_{\mathrm{Nd}(0)}$ entre 0,52-1,95 e $\mathrm{e}_{\mathrm{Nd}(\mathrm{T})}$ 0,65-2,12, indicando fonte mantélica com algum grau de contaminação crustal. Os valores de $\mathrm{T}_{\mathrm{DM}}(\mathrm{Ga})$ variam de $0,47-0,53$. As razões ${ }^{87} \mathrm{Sr} /{ }^{86} \mathrm{Sr}$ estão entre 0,70475-0,70627, indicando que a fonte dos magmas é o manto litosférico depletado. Dados ${ }^{40} \mathrm{Ar}$ -

${ }^{39} \mathrm{Ar}$ sobre biotitas hidrotermais indicam idades entre 11-14 Ma. O sistema de falhas strike-slip N-S foi o mecanismo responsável pela ascensão do magma de composição granodiorítica, o qual era enriquecido em voláteis. Durante o Mioceno, as fases finais de resfriamento, cristalização e liberação dos voláteis foram responsáveis pela formação das zonas de alteração hidrotermal e pela mineralização, que é associada ao topo dos pórfiros, além de se estenderem para a encaixante e brechas, as quais foram formadas pelo alívio de tensão e pela liberação violenta dos voláteis.

PALAVRAS-CHAVE: Cu-Mo Pórfiro, Cordilheira Oriental, Andes Centrais. 


\section{ABSTRACT}

The Pancho Árias Cu-Mo deposit, located in the eastern cordillera of the argentine Central Andes, is the oldest member of the Las Burras-Almagro-El Toro magmatic complex that constitute one of the main Tertiary igneous bodies located in the Calama-Olacapato-El Toro lineament. The area hosts four magmatic intrusive members in a Neoproterozoic metasedimentary basement. These members are two porphyritic andesites, one quartz-monzodioritic stock and a rhyodacitic to trachyandesitic dike and sill system. Breccia bodies occur related to the porphyry members, and to the stock. The deposit location, as well as the textural and compositional variations, allowed us to individualize six breccia bodies, which vary from polymitic to monomitic types, and matrix suported to fragment suported. In general, the B.n breccias host the part of the $\mathrm{Cu}$ mineralization, in which it is formed of chalcopyrite crystals, that occasionally exhibit alteration to covellite. However, the mineralization also extends to the country rocks trapped in venules and stockwork structures. In this situation the Mo mineralization predominate and occurs as molybdenite crystals associated to quartz veins. The registered hydrothermal alteration is of the concentric zonal type, with the potassic core gradually moving to a propylitic distal zone. The phyllic alteration occurs associated to the NW-SE fault. The magmatic phases are alkali-calcic to calc-alkaline and are peraluminous to metaluminous, and the magmatism were classified as cordillerian I-type, formed in a volcanic arc. They exhibit a slighly LREE fractionation in relation to HREE $\left([\mathrm{La} / \mathrm{Yb}]_{\mathrm{N}}=6-12\right)$ and discreet Eu anomalies $\left(\mathrm{Eu} / \mathrm{Eu}^{*}=0.2-0.9\right)$. The multielementar patern is similar to upper crust rocks, with Nb-P-Ti negative anomalies and $\mathrm{Rb}-\mathrm{Sm}-\mathrm{Tb}$ positive anomalies. The ${ }^{147} \mathrm{Sm} /{ }^{144} \mathrm{Nd}$ ratios of the magmatic phases indicate values of $0.0985-0.1115$. The ${ }^{143} \mathrm{Nd} /{ }^{144} \mathrm{Nd}$ ratios vary between $0.512665-0.512738$, values that generate $\mathrm{e}_{\mathrm{Nd}(0)}$ between $0.52-1.95$ and $\mathrm{e}_{\mathrm{Nd}(\mathrm{T})}$ of $0.65-2.12$, indicating a mantle source with some degree of crustal contamination. The $\mathrm{T}_{\mathrm{DM}}(\mathrm{Ga})$ values vary between $0.47-0.53$. The ${ }^{87} \mathrm{Sr} /{ }^{86} \mathrm{Sr}$ ratios ranging between $0,70475-0,70627$, that indicated depleted lithospheric mantle source from magmas. ${ }^{40} \mathrm{Ar}-{ }^{39} \mathrm{Ar}$ data of hydrothermal biotite indicate ages of 11-14 Ma. The data show that the strike-slip fault system is the responsible mechanism by the rise of granodiorite volatile-rich magma. During the Miocene, the final phases of cooling, crystalization, and release of volatiles processes generated the zoned hydrothermal alteration and the $\mathrm{Cu}-\mathrm{Mo}$ mineralization, it is associated to the apix part of porphyry bodies, also extending to the country rocks and breccia bodies, which are were formed by stress relief and violent release of volatiles.

KEYWORDS: Cu-Mo porphyry, Eastern Cordillera, Central Andes. 


\section{Sumário}

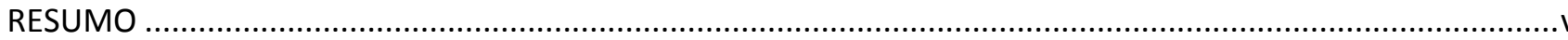

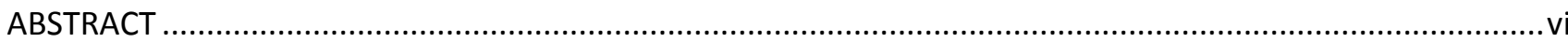

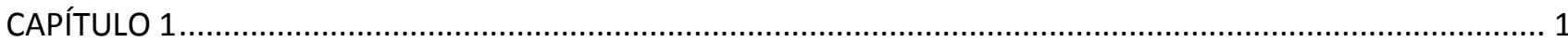

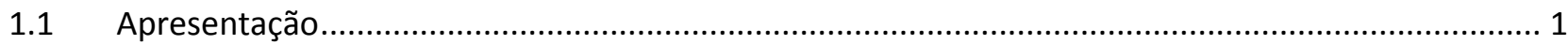

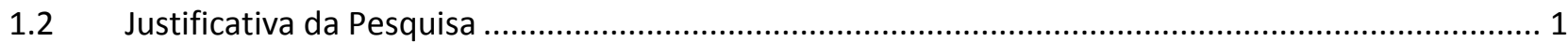

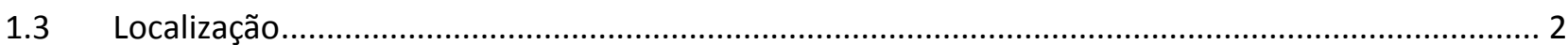

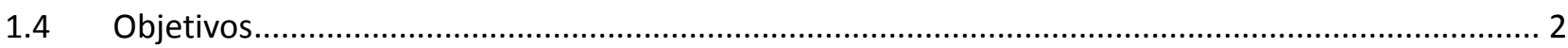

1.5 Métodos Analíticos Aplicados .......................................................................................... 3

1.6 Síntese do Conhecimento Geológico Regional..................................................................

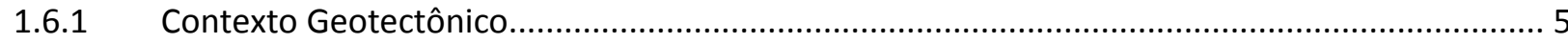

1.6.2 Litoestratigrafia da Cordilheira Oriental.............................................................. 7

1.6.3 Geologia do Complexo Magmático Las Burras-Almagro-El Toro .............................................. 10

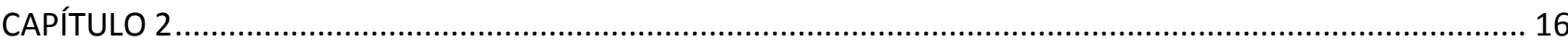

2.1 Geologia do Depósito Cu-Mo Tipo Pórfiro Pancho Árias............................................................. 16

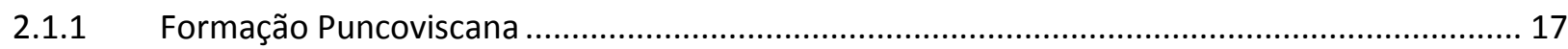

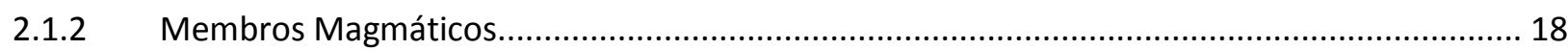

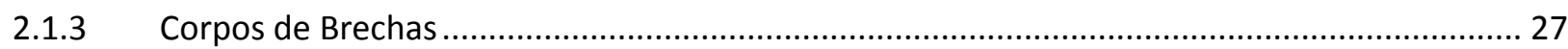

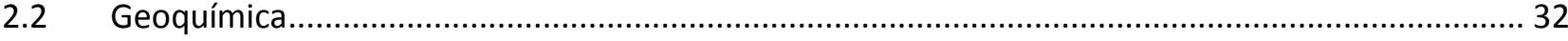

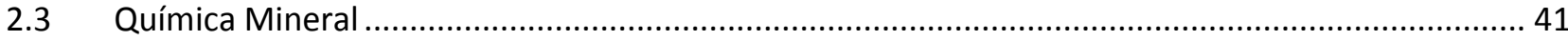

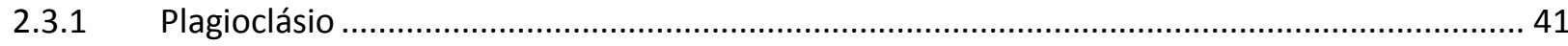

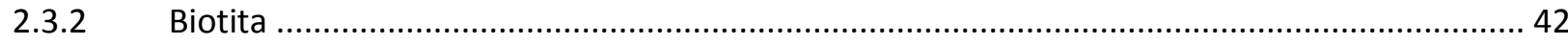

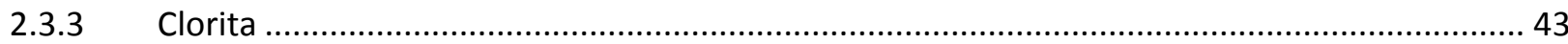

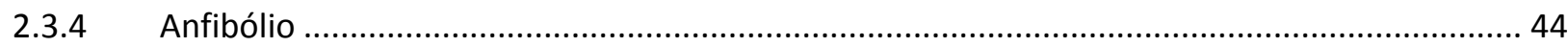

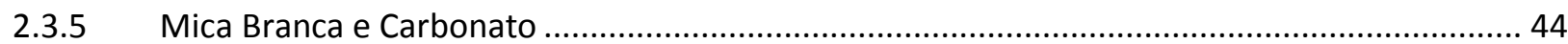

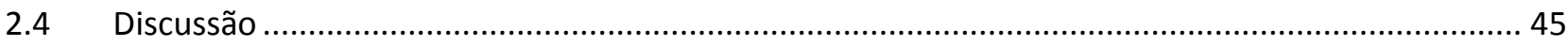

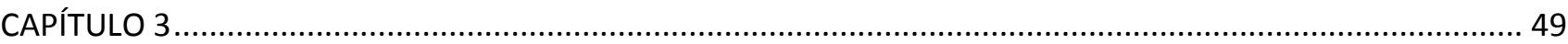

3.1 Sistema de Alteração Hidrotermal ........................................................................ 49

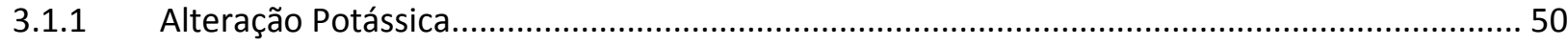

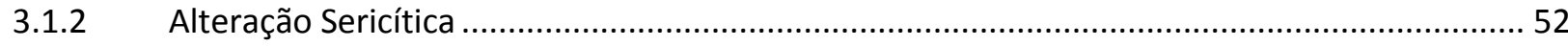

Alteração Propilítica ....................................................................................... 53

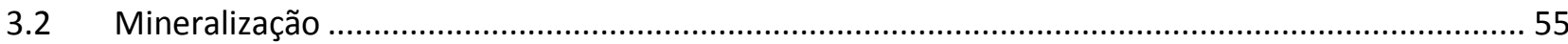

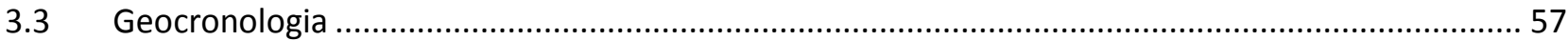




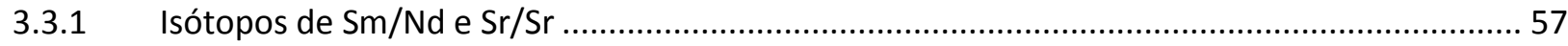

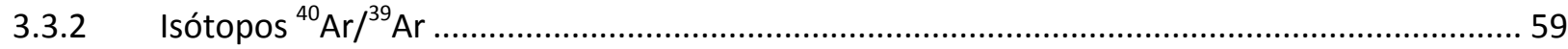

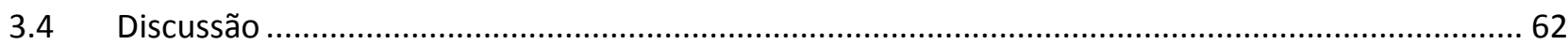

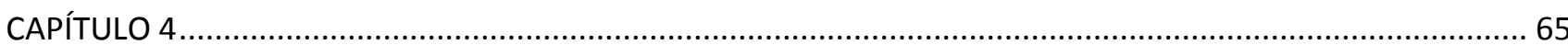

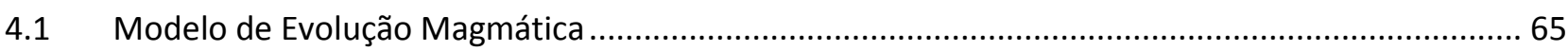

4.1.1 Estágio I - Geração e Alojamento dos Magmas ..................................................................... 65

4.1.2 Estágio II - Alteração hidrotermal dos tipos potássica e propilítica com zonação do tipo

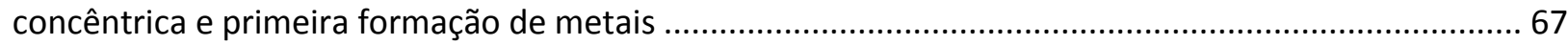

4.1.3 Estágio III - Geração dos Veios de Quartzo em Estruturas Stockwork ..................................... 68

4.1.4 Estágio IV - Resfriamento, Deposição de Metais e Primeira Formação de Brechas .................. 69

4.1.5 Estágio V - Alojamento do Stock Monzodiorítico e Segunda Formação de Brechas.................. 71

4.1.6 Estágio VI - Alteração fílica sobreposta e formação dos diques................................................ 71

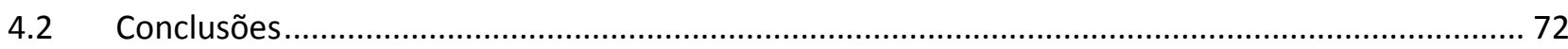

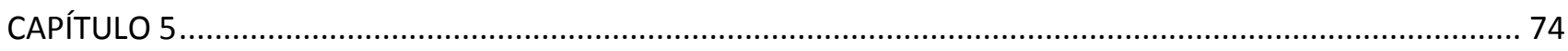

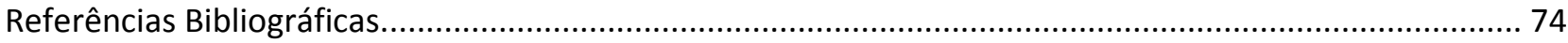

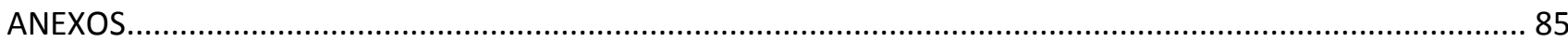




\section{LISTA DE FIGURAS}

Figura 1.1- Localização da área de estudo, ressaltando as vias de acesso utilizadas para o trabalho de campo, assim como as localidades próximas ao local e a delimitação da área do projeto.

Figura 1.2 - Representação esquemática das províncias geotectônicas dos Andes Centrais (Adaptado de Gioncada et al., 2010)

Figura 1.3 - Contexto geológico do complexo magmático Las Burras-Almagro-El Toro e bacia El Toro, localizando as datações já realizadas na área e suas seções estratigráficas (Adaptado de Mazzuoli, et al., 2008)

Figura 1.4 - Seções estratigráficas na região do complexo Las Burras-Almagro-El Toro, exibindo correlação dos membros vulcânicos Almagro e da bacia El Toro (Adaptado de Mazzuoli et al., 2008)...... 15

Figura 2.1- Imagem aérea do depósito Pancho Árias, ressaltando os principais setores do depósito. 16

Figura 2.2 a) relações e contatos entre os membros magmáticos, brechas e rocha encaixante da área. b) detalhe do denso stockwork que afeta as rochas metassedimentares da Formação Puncoviscana. c) detalhe das relações de intrusão entre os pórfiros andesíticos e as rochas metassedimentares da rocha encaixante. d) sill na Formação Puncoviscana.

Figura 2.3- Mapa e perfil geológico do depósito Pancho Árias....................................................................... 18

Figura 2.4 - Micrografias ressaltando o arranjo microtextural do pórfiro andesítico com biotita................... 20

Figura 2.5- Micrografias do pórfiro andesítico com anfibólio..................................................................... 22

Figura 2.6- Diagrama QAFP de classificação de rochas plutônicas, proposto por Streckeisen, 1976............... 23

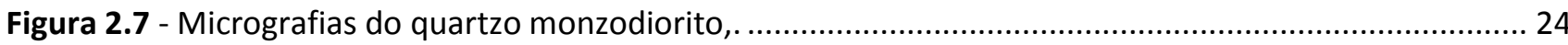

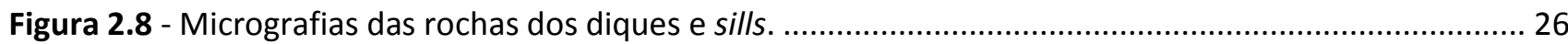

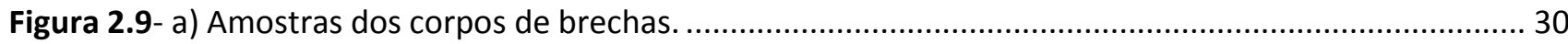

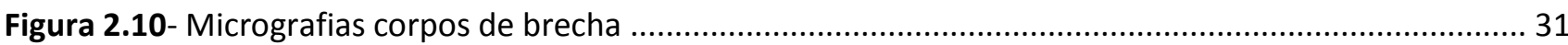

Figura 2.11 Diagrama de classificação de rochas vulcânicas $\left(\mathrm{Zr} / \mathrm{TiO}_{2} \times \mathrm{Nb} / \mathrm{Y}\right)$, proposto por Winchester \& Floyd, 1977.

Figura 2.12- a) Diagrama $\mathrm{Na}_{2} \mathrm{O}+\mathrm{K}_{2} \mathrm{O}-\mathrm{CaO} \times \mathrm{SiO}_{2}$ de classificação de alcalinidade para rochas graníticas proposto por Frost et al. (2001). b) Diagrama A/NK x ASI de classificação de aluminosidade para rochas graníticas proposto por Frost et al. (2001). c) Diagrama A/NK x A/CNK de classificação de aluminosidade para rochas graníticas proposto por Shand (1943).

Figura 2.13- Diagrama FeOt/(FeOt + $\mathrm{MgO}) \times \mathrm{SiO}_{2}$ para classificação de granitos, proposto por Frost et al. (2001).

Figura 2.14- a) Diagrama de classificação geotectônica para rochas graníticas ( $R b \times \mathrm{Y})+\mathrm{Nb}$. b) Diagrama de classificação geotectônica para rochas graníticas ( $\mathrm{Nb} \times \mathrm{Y})$. c) Diagrama de classificação geotectônica para rochas graníticas $\mathrm{Rb} \times \mathrm{Ta}+\mathrm{Yb}$. d) Diagrama de classificação geotectônica para rochas graníticas Ta $\times$ Yb. Todos propostos por Pearce et al. (1984).

Figura 2.15 - Diagrama $\mathrm{Ba} / \mathrm{Nb}$ x Nb de elementos traço para as rochas do prospecto Pancho Árias. 38 
Figura 2.16- Diagramas de padrão dos ETR normalizados à condrito, proposto por Boynton (1984). Diagrama de padrão multielementar proposto por Thompson (1982). Em cinza padrões das amostras, em preto padrões da crosta superior e em verde, padrão da crosta média.

Figura 2.17- a) Diagrama ternário de classificação de plagioclásio (Albita-Anortita-Ortoclásio) para as diferentes amostras analisadas. b) Diagrama ternário de classificação de plagioclásio (Albita-AnortitaOrtoclásio) para os diferentes setores analisados nos grãos

Figura 2.18 - a) Diagrama $\mathrm{Mg}^{2+}$ x Fe para os grãos de biotita analisados, exibindo três campos bem definidos.

b) Diagrama Mg/Fe+Mg x Al total para classificação de biotitas, proposto por Hey's (1954)...... 43

Figura 2.19 - Diagrama Si(afpu) x Fe/Fe+Mg para classificação de cloritas. Proposto por Hey's, 1954. 43

Figura 2.20- Diagrama Si(apfu) $\times \mathrm{Mg} / \mathrm{Mg}+\mathrm{Fe}^{2+}$ para a classificação de anfibólios cálcicos, proposto por Leake et al., 1997.

Figura 2.21 - a, b e c) Mecanismos que exemplificam processo de difusão responsável pela zonação oscilatória dos plagioclásios do depósito Pancho Árias. d) Conteúdo de $\mathrm{Fe}^{3+}$ vs An(\%) nos plagioclásios zonados. Símbolos iguais da figura 2.19 ...

Figura 2.22 - Diagramas de classificação das biotitas analisadas. a, b e c) Classificação em relação as séries magmáticas e ambientes de formação ( Nachit et al., 1985; Abdel-Rahman's, 1994. d) Classificação em relação as séries e condições de oxidação.

Figura 3.1- Mapa de alteração hidrotermal do depósito Cu-Mo Pancho Árias, ressaltando as três zonas e as litologias presentes.

Figura 3.2- Micrografias da alteração hidrotermal potássica.

Figura 3.3- Diagrama triangular ( $\left.\mathrm{MnO}+\mathrm{FeO} \times 10 \times \mathrm{TiO}_{2} \times \mathrm{MgO}\right)$ para classificação de biotitas primárias, reequilibradas e neoformadas, proposto por Nachit et al. (2005).

Figura 3.4- Micrografias da alteração hidrotermal sericítica. 53

Figura 3.5- Micrografias da alteração hidrotermal propilíitica.

Figura 3.6- a) Diagrama $\mathrm{Al}^{\mathrm{iv}} \mathrm{x} \mathrm{Fe} / \mathrm{Fe}+\mathrm{Mg}$ que exibe enriquecimento em Fe das cloritas durante a alteração hidrotermal propilítica. b) Diagrama $\mathrm{Mg} \times \mathrm{Fe}^{3+}+\mathrm{Fe}^{2+}$ que exibe enriquecimento em Fe das cloritas durante a alteração hidrotermal propilítica.

Figura 3.7- a) Textura disseminada e/ou incrustado dos sulfetos no pórfiro andesítico. b) Textura disseminada dos sulfetos no corpo de brecha B.n-01, sulfetos estão tanto na matriz como nos fragmentos. c) Mineralização venulada em arranjo stockwork das rochas encaixantes metassedimentares. 55

Figura 3.8- Micrografias da mineralização 56

Figura 3.9- Diagrama ${ }^{87} \mathrm{Sr} /{ }^{86} \mathrm{Sr} x \mathrm{\varepsilon Nd}(\mathrm{t})$ Diagrama $\mathrm{Sr} x \mathrm{Nd}$ comparando os dados deste estudo com as curvas de evolução isotópica de Sm e Nd para os reservatórios modelos com os campos contendo sua provável composição média atual. Pontos ao longo de cada curva indica incremento de tempo de 0,1 Ga. (Zartman \& Haines, 1988).

Figura 3.10 - Evolução isotópica Sm-Nd (idades e $\varepsilon N d$ ) para as rochas analisadas. 59

Figura 3. 11- Resultados da análise da biotita da amostra PA 102 a) Idades platô ${ }^{40} \mathrm{Ar} /{ }^{39} \mathrm{Ar}$; B) relações $\mathrm{Ca} / \mathrm{K}$ aplicadas ao cálculo da Idade Ar-Ar. c) relações $\mathrm{Cl} / \mathrm{K}$ aplicadas ao cálculo da Idade $\mathrm{Ar}-\mathrm{Ar}$. 
Figura 3. 12- Resultados da análise da biotita da amostra PA 103 a) Idades platô $\left.{ }^{40} \mathrm{Ar} /{ }^{39} \mathrm{Ar} ; \mathrm{B}\right)$ relações Ca/K aplicadas ao cálculo da Idade Ar-Ar. c) relações Cl/K aplicadas ao cálculo da Idade Ar-Ar.

Figura 3.13- Modelos de zonas de alteração hidrotermal e zonas de mineralização em depósitos de Cu do tipo pórfiro destaca-se colocação do depósito Pancho Árias. Proposto por Lowell \& Guilbert (1970). 63

Figura 4.1- Evolução geológica do depósito Pancho Árias. 66

Figura 4.2- Associação mineral desenvolvida ao longo da evolução geológica do depósito de Cu e Mo tipo pórfiro Pancho Árias.

\section{LISTA DE TABELAS}

Tabela 2.1 - Composição química das quatro fases magmáticas do depósito Pancho Árias 33

Tabela 3.1 - Síntese dos dados geocronológicos do complexo magmático Las Burras - Almagro - El Toro ..... 57

Tabela 3.2 - Resultados das análises Sm-Nd e Rb-Sr........................................................................ 58

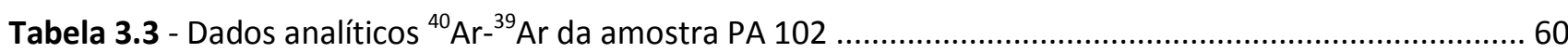

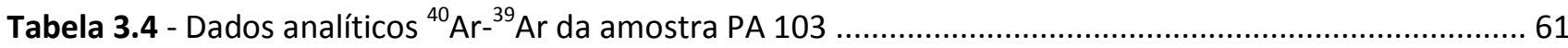




\section{CAPÍTULO 1}

\subsection{Apresentação}

A presente pesquisa, apresentada sob a forma de uma dissertação, faz parte do requisito básico para obtenção do título de Mestre em Geologia, na subárea de Prospecção Geologia Econômica, junto ao Programa de Pós-graduação em Geologia da Universidade de Brasília.

$\mathrm{O}$ objetivo dessa pesquisa é apresentar o contexto geológico da área do depósito de $\mathrm{Cu}-\mathrm{Mo}$ pórfiro Pancho Arias (Argentina), detalhando as características petrográficas, geoquímicas, de química dos minerais e geocronológicas dos diferentes tipos de rochas. Tais dados formam o suporte básico para a proposta de um modelo geológico de evolução magmática e metalogenética para o depósito acima citado.

Para tal, foi desenvolvida uma parceria técnico-científica entre professores de programas de pósgraduação de instituições do Brasil e da Argentina, aqui representadas pela Universidade de Brasília (UnB) e pela Universidad Nacional de Salta (UNSa). Parceria essa que permitiu, por parte da UNSa, apoio logístico para os trabalhos de campo e preparação preliminar de amostras de rochas coletadas, enquanto que por parte da UnB, coube as análises laboratoriais mais específicas.

\subsection{Justificativa da Pesquisa}

O depósito de Cu-Mo pórfiro de Pancho Árias é interpretado como corpo magmático do membro Las Burras, unidade mais antiga do complexo magmático Las Burras-Almagro-El Toro, que localiza-se na borda oeste da província morfoestrutural Cordilheira Oriental, mais precisamente ao longo do lineamento Calama-Olacapato-El Toro. Vários trabalhos já foram feitos neste complexo magmático, porém poucos deles realizaram estudos no corpo intrusivo gerador do depósito mineral estudado nesta dissertação.

As informações apresentadas neste trabalho servirão para avançar na compreensão da evolução magmática do depósito de Cu-Mo pórfiro de Pancho Árias, bem como nos processos metalogenéticos envolvidos na mineralização. 
"O Sistema Magmático do Depósito de Cu-Mo Tipo Pórfiro Pancho Árias, Cordilheira Oriental, Argentina" Rafael Bellozupko Stremel

\subsection{Localização}

O depósito Pancho Árias localiza-se $30 \mathrm{~km}$ ao nordeste da localidade Santa Rosa de Tastíl, no distrito de Rosário de Lerma, província de Salta (Figura 1.1). A área do projeto é delimitada pelas coordenadas $24^{\circ} 15^{\prime} 15^{\prime \prime} \mathrm{S}$ ao norte, $24^{\circ} 16^{\prime} 30^{\prime \prime} \mathrm{S}$ ao sul, $65^{\circ} 50^{\prime} 05^{\prime \prime} \mathrm{W}$ a leste e $65^{\circ} 51^{\prime} 80^{\prime \prime} \mathrm{W}$ a oeste, pelo sistema de coordenadas geográficas e possui aproximadamente $11 \mathrm{~km}^{2}$ de área total e elevação média de $3600 \mathrm{~m}$ acima do nível do mar.

A partir da cidade de Salta, segue-se pela rota nacional No51 até a localidade de Las Cuevas, perto deste povoado percorre-se por $40 \mathrm{~km}$ ao nordeste por estradas não pavimentadas até a localidade de Finca El Toro, a partir deste ponto percorre-se mais $10 \mathrm{~km}$ ao sul, até chegar a região de Pancho Árias (Figura ).
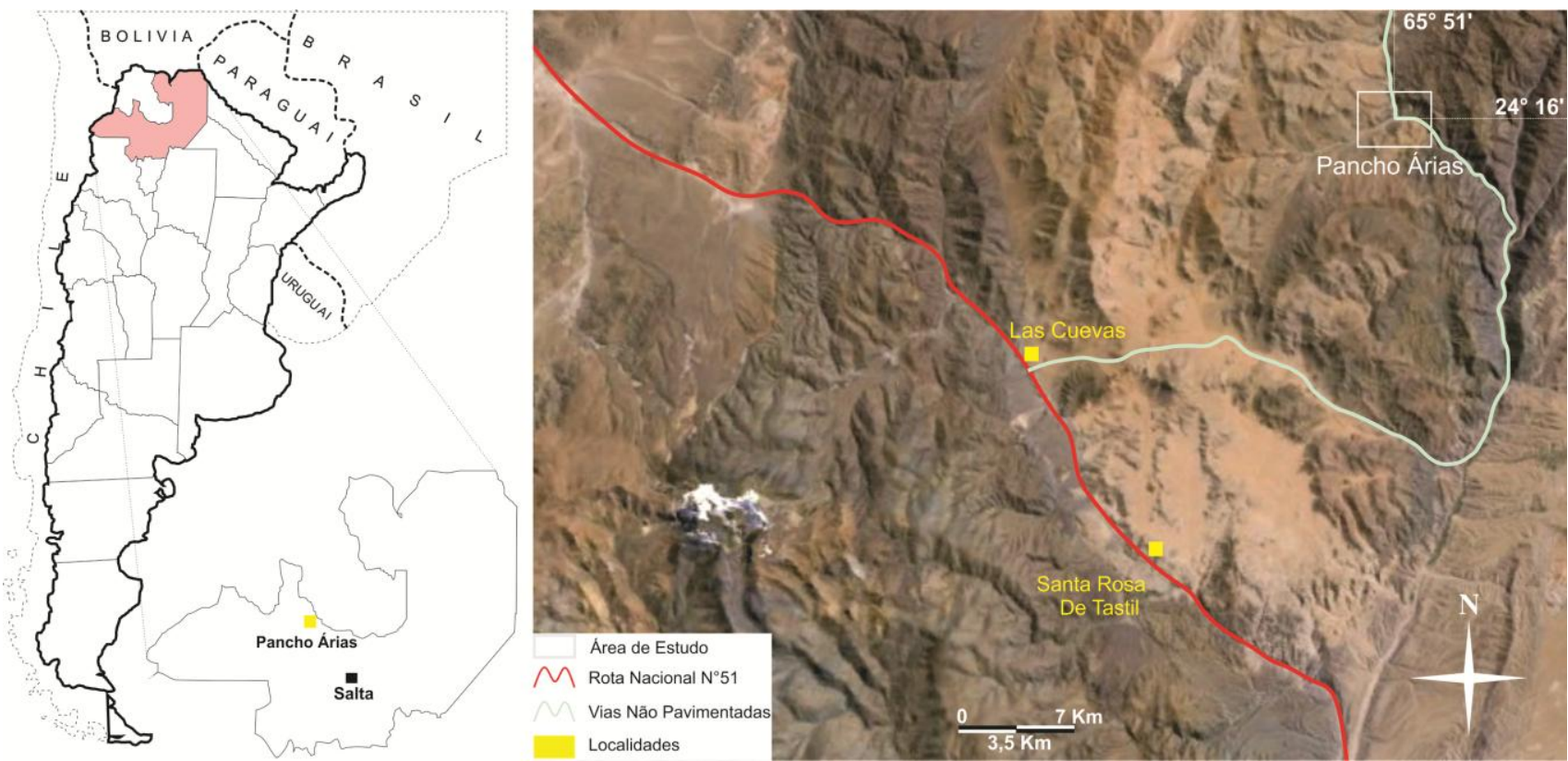

Figura 1.1- Localização da área de estudo, ressaltando as vias de acesso utilizadas para o trabalho de campo, assim como as localidades próximas ao local e a delimitação da área do projeto.

\subsection{Objetivos}

- Caracterização petrográfica e geoquímica das principais fases magmáticas na área do depósito de $\mathrm{Cu}-\mathrm{Mo}$ do tipo pórfiro Pancho Árias.

- Identificar a paragênese mineral associada a esse tipo de mineralização, aplicando estudo de química mineral e microscopia eletrônica de varredura; 
- Obtenção de dados de geologia isotópica (Sm-Nd, Sr-Sr \& Ar-Ar) das diferentes fases magmáticas;

- Propor um modelo geológico que busque explicar os processos magmáticos e metalogenéticos envolvidos na gênese do deposito de $\mathrm{Cu}$-Mo Pancho Árias.

\subsection{Métodos Analíticos Aplicados}

A pesquisa foi desenvolvida em quatro etapas básicas, assim denominadas: pré-campo, campo, laboratório e escritório.

Pré-campo - envolveu pesquisa bibliográfica sobre o estágio de conhecimento geológico dos sistemas andinos, com ênfase na evolução da Cordilheira Oriental argentina, bem como os recursos minerais associados. Buscou-se ainda, bibliografias específicas sobre a evolução magmática e metalogenética dos sistemas magmáticos do tipo pórfiro conhecidos no mundo.

Campo - desenvolvida no período de 28 de outubro a 1 de novembro de 2014. Envolveu reconhecimento geológico da área do depósito de $\mathrm{Cu}$-Mo pórfiro Pancho Arias, acompanhado de coleta de rochas, elaboração de seções e confecção de mapa geológico, aliados a um trabalho preliminar de preparação de amostras para as subsequentes análises laboratoriais.

Laboratório - Essa etapa exigiu maior carga de tempo, pois envolveu catalogação de amostras, preparação criteriosa de amostras de rochas, separação de fases minerais e análises laboratoriais.

- Descrição petrográfica de 40 lâminas delgadas polidas de rochas coletadas em afloramentos, ressaltando os arranjos microtexturais e as associações minerais, cujas análises foram realizadas no Laboratório de Microscopia do Instituto de Geociências da Universidade de Brasília (IG-UnB). Nesse estudo utilizou-se microscópio da marca Olympus equipado com objetivas de até 100x e ocular de 10x.

- Análise química em 11 amostras de rocha total, as quais foram britadas e posteriormente pulverizadas através de panela de tungstênio, produzindo cerca de $20 \mathrm{~g}$ de material. Alíquotas de cerca de $10 \mathrm{~g}$ de amostras foram então encaminhadas ao laboratório ACME - Analytical Laboratories lda (Vancouver-Canadá). O pacote de análise escolhido foi o LF 200, o qual abrange elementos maiores, menores, alguns elementos traços e todos os elementos terras raras, aplicados a análises por ICP-AES e ICP-MS. Amostra é preparada em uma mistura com fluxo de $\mathrm{LiB}_{\mathrm{O} 2} / \mathrm{L}_{\mathrm{i} 2 \mathrm{~B} 407}$. Os cadinhos são fundidos num forno. A gota arrefecida é dissolvida em ácido nítrico ACS grau e analisadas por ICP e / ou ICP-MS. Perda por combustão (LOI) por meio 
da combustão da amostra é determinada uma divisão, medindo a perda de peso. Carbono e enxofre total podem ser incluídos e são determinados pelo método Leco (TC003).

- Análises em microssonda eletrônica da composição química das diversas fases minerais foram feitas em 13 lâminas polidas. As análises foram realizadas no laboratório de microssonda eletrônica do Instituto de Geociências da Universidade de Brasília (IG-UnB). Utilizou-se o equipamento da marca JEOL, modelo Superprobe JXA-8230, acoplado com 5 espectrômetros e detector EDS (Energy Dispersive spectrometer). Para a obtenção de imagens por elétrons retroespalhados (backscattered electrons ou BSE) utilizou-se aceleração de voltagem variando de 15 $\mathrm{kV}$, para óxidos e silicatos a $20 \mathrm{kV}$, para sulfetos. Para cada canal analizado condições específicas foram utilizadas.

- As análises isotópicas de Ar-Ar sob cristais de biotita hidrotermal foram realizadas na Queens University. E as análises de $\mathrm{Sm}-\mathrm{Nd}$ e $\mathrm{Sr}-\mathrm{Sr}$ em rocha rocha total das diferentes fases magmáticas foram realizadas no Laboratório de Geocronologia e Geologia Isotópica da UnB, utilizando o seguinte procedimento analítico:

- Sm-Nd: 3 amostras de rochas foram analisadas (rocha-total) segundo os procedimentos descritos por Gioia \& Pimentel (2000). Cerca de $50 \mathrm{mg}$ de rocha foram pulverizadas em panela de ágata, misturadas com solução de spike ${ }^{149} \mathrm{Sm}^{150} \mathrm{Nd}$ e dissolvidas em cápsulas de Savillex. A extração de Sm e Nd seguiu a técnica convencional com colunas de Teflon contendo LNSpecresin (HDEHP - diethylhexil phosphoric acid supported on PTFE powder). As amostras de $\mathrm{Sm}$ e $\mathrm{Nd}$ foram alojadas em filamentos de reevaporação em conjuntos de filamentos duplos e as medidas isotópicas foram feitas em espectrômetro de massa do tipo multicoletor Finnigan MAT 262. O grau de incertezas para as razões ${ }^{149} \mathrm{Sm} /{ }^{150} \mathrm{Nd} \mathrm{e}{ }^{143} \mathrm{Nd} /{ }^{144} \mathrm{Nd}$ é menor que $\pm 0,4 \%(1 \sigma)$ e $\pm 0,005 \%(1 \sigma)$, respectivamente, de acordo com análises do padrão internacional BHVO-1 e BCR-1. As razões ${ }^{143} \mathrm{Nd} /{ }^{144} \mathrm{Nd}$ foram normalizadas para ${ }^{146} \mathrm{Nd} /{ }^{144} \mathrm{Nd}$ de 0,7219 , e a constante de decaimento usada foi $6,54 \times 10^{-12}$ a $10^{-1}$. Valores TDM foram calculados segundo método de DePaolo (1981).

- Sr/Sr: Para análises da razão ${ }^{87} \mathrm{Sr} /{ }^{86} \mathrm{Sr}$ das três amostras analisadas foram utilizados os procedimentos químicos descritos por Asmeron et al. (1991), e 
Kaufman et al. (1993). A razão ${ }^{87} \mathrm{Sr} /{ }^{86} \mathrm{Sr}$ foi determinada usando a espectrômetro de massa Finningan MAT 262 por ionização termal no Laboratório de Geocronologia e Geologia Isotópica da Universidade de

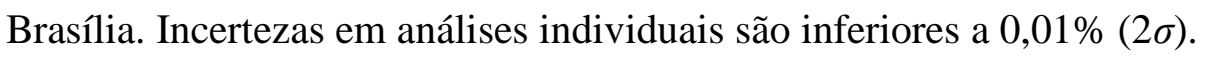

- Ar/Ar: A análise geocronológica ${ }^{40} \mathrm{Ar} /{ }^{39} \mathrm{Ar}$ foi realizada no laboratório de geologia isotópica da Queen's University, Department of the Geological Sciences \& Geological Engineering (Ontário-Canadá), sob a supervisão do Prof. D.A. Archibald. Foi aplicada em 2 amostras de biotita das fases magmáticas P1 e P2. As quais foram irradiadas por cerca de 40 horas em um reator nuclear do tipo McMaster. As determinações foram feitas através de um laser de íon Ar de $8 \mathrm{~W}$ do tipo Lexel 3500, e com espectrômetro de massa do tipo MAP 216, com fonte Signer Baur e um multicoletor de elétrons. As medidas dos isótopos de argônio foram normalizadas à razão atmosférica ${ }^{40} \mathrm{Ar} /{ }^{36} \mathrm{Ar}$ segundo preposição de Roddick (1983). As idades e os erros foram corrigidos usando as fórmulas propostas por Steiger \& Jäger (1977) e Dalrymple et al. (1981). As idades e os erros apresentados possuem uma precisão analítica de $2 \sigma$ ou $0,5 \%$, adequados ao espectro de variação para forma de platô McDougall \& Harrison (1988). As idades obtidas foram referenciadas para o padrão Hb3Gr (hornblenda) em $1072 \mathrm{Ma}$ de Roddick (1983).

- O imageamento de fases minerais em seis lâminas delgadas polidas feitas no Laboratório de Geocronologia e Geologia Isotópica da UnB com Microscópio Eletrônico de Varredura (MEV) marca FEI QUANTA 450, realizando uma análise preliminar de EDS (Energy Dispersive Spectrometer) e a principal de EDAX, o aumento utilizado foi de 100 a 1000X. As amostras foram metalizadas com carbono e analisadas em alto vácuo. Para a obtenção das imagens por elétrons retroespalhados (backscattered electrons ou BSE) utilizou-se a aceleração de voltagem de $20 \mathrm{kV}$, distância de trabalho de 15 mm e tempo de contagem de 30".

\subsection{Síntese do Conhecimento Geológico Regional}

\subsubsection{Contexto Geotectônico}

A Cordilheira dos Andes e o arco magmático associado possuem idade cenozoica e são resultados da convergência moderadamente obliqua entre as placas de Nazca e Sul Americana sob 
"O Sistema Magmático do Depósito de Cu-Mo Tipo Pórfiro Pancho Árias, Cordilheira Oriental, Argentina" Rafael Bellozupko Stremel

um ângulo de aproximadamente $20^{\circ}$ entre o vetor de movimento da placa e do limite de placa normal (Dewey \& Lamb, 1992; Scheuber \& Reutter, 1992). Diversas atividades geológicas associadas à evolução do arco magmático vêm acompanhando a edificação dos Andes desde o Mesozoico. Nos Andes centrais o arco vulcânico jurássico foi alojado na atual Cordilheira Costeira e Pré cordilheira Chilena. Durante o Mioceno e o Quaternário, o arco migrou progressivamente para o leste até a atual Cordilheira Oriental (Marrett et al., 1994; Drozdzewski \& Mon, 1999; Giese et al., 1999; Scheuber \& Giese, 1999; Reynolds et al., 2000; Riller et al., 2001). Ao leste, em aproximadamente $24^{\circ} \mathrm{S}$, a Cordilheira Frontal é representada pelo sistema de falhas thick-skinned Santa Bárbara e a bacia de foreland Chaco Plain, ambos desenvolvidos sobre o escudo brasileiro (Omarini \& Götze, 1991; Horton \& DeCelles, 1997; Babeyko \& Sobolev, 2005).

Os Andes Centrais são cortados por um sistema de falhas com trend NW-SE, que se estende da costa do pacífico até $600 \mathrm{~km}$ dentro do continente, o principal destes sistemas é denominado como Calama-Olacapato-El Toro (Figura 1.2). Embora as informações sobre a geometria e a cinemática destas falhas transversais sejam limitadas, elas foram interpretadas com idades paleozoicas e com reativação devido à convergência oblíqua entre as placas de Nazca e Sul Americana. Um intenso magmatismo Mioceno-Quarternário se desenvolveu ao longo destes sistemas de falhas em ambientes de arco e retroarco, formando complexos vulcânicos transversais. O magmatismo associado ao sistema Calama-Olacapato-El Toro ocorreu entre $17 \mathrm{Ma}$ e o quaternário, com atividade máxima entre 10 e 5 Ma (Kay et al., 1999; Petrinovic et al., 1999; Matteini et al., 2002a, 2002b; Hongn et al., 2002; Haschke \& Ben-Avraham, 2005). Este magmatismo ocorreu concomitantemente ao soerguimento e deformação da Puna norte e Cordilheira Oriental, e coincide com uma mudança de vergência para leste da compressão do platô sobre o foreland (Gubbels et al., 1993). O cinturão vulcânico ao longo do sistema Calama-Olacapato-El Toro compreende estrato vulcões e grandes caldeiras com lâminas de ignibritos e diversos eventos intrusivos. Os produtos magmáticos têm variadas idades e assinatura geoquímica de arco vulcânico. A variação reflete diferentes fontes de magma e espessamento crustal (Matteini et al., 2002a, b). Os centros basálticoandesito monogenéticos de idade plioceno-quarternária, alojados no platô altiplano-puna são relacionados à delaminação litosférica em regime extensional, ativo desde 3-4 Ma (Cabrera et al., 1987; Marrett \& Emerman, 1992; Marrett et al., 1994; Kay et al., 1994). 
"O Sistema Magmático do Depósito de Cu-Mo Tipo Pórfiro Pancho Árias, Cordilheira Oriental, Argentina" Rafael Bellozupko Stremel

\subsubsection{Litoestratigrafia da Cordilheira Oriental}

A província morfoestrutural da Cordilheira Oriental é limitada a leste e oeste pelas províncias geológicas de Puna e Serras Subandinas respectivamente, e diferencia-se dessas unidades por sua estratigrafia, que engloba rochas do Neoproterozoico até o Neogeno (Figura 1.3).

A Formação Puncoviscana, de idade neoproterozoica, é o embasamento da província. Esta Formação é composta por uma sequência de rochas metassedimentares representadas por pelitos, arenitos, grauvacas e quartzitos de baixo grau metamórfico, as quais foram depositadas em ambiente marinho em sequências turbidíticas e deformada por efeito da fase tilcárica. $\mathrm{O}$ ambiente de deposição corresponde a uma bacia marinha intracontinental do tipo rift, seguido de margem passiva (Mon, 1999; Omarini et al.,1999). Os principais traços estruturais são falhas submeridionais terciárias e o grande lineamento Calama-Olacapato-El Toro.

Sobre a Formação Puncoviscana, em discordância angular, foram depositadas as rochas do Grupo Mesón, de idade cambriana superior. A base do grupo é a Formação Lizoite, caracterizada por uma sequência granodecrescente, representada por um conglomerado basal que passa a níveis superiores de quartzito com laminação paralela e cruzada, esta variação é correspondente à sequência transgressiva inicial depositada sobre o embasamento. A bacia do Grupo Mesón é do tipo intracratônica, formada ao longo de uma linha de sutura que conectava o cráton de ArequipaAntofalla, ao oeste, e o cráton Rio de La Plata, ao leste (Sanchez, 1999). Acima na estratigrafia, há a Formação Campanario, que se inicia sob a sequência de transgressão e tem sua base composta por um quartzito de granulação média a fina de coloração verde e estratificação paralela. $\mathrm{O}$ topo da Formação é caracterizado pela alternância de quartzitos finos e pelitos, caracterizados por sinais de bioturbação (Sánchez \& Salfity, 1990). O topo do grupo é formado pela Formação Chalhualmayoc, caracterizada por uma unidade granocrescente de quartzitos com estratificação cruzada, a qual comumente é dividida em três unidades: uma basal de quartzitos com laminação cruzada, uma intermediária de quartzitos com laminação paralela e uma superior de quartzitos maciços (Sánchez, 1999). 


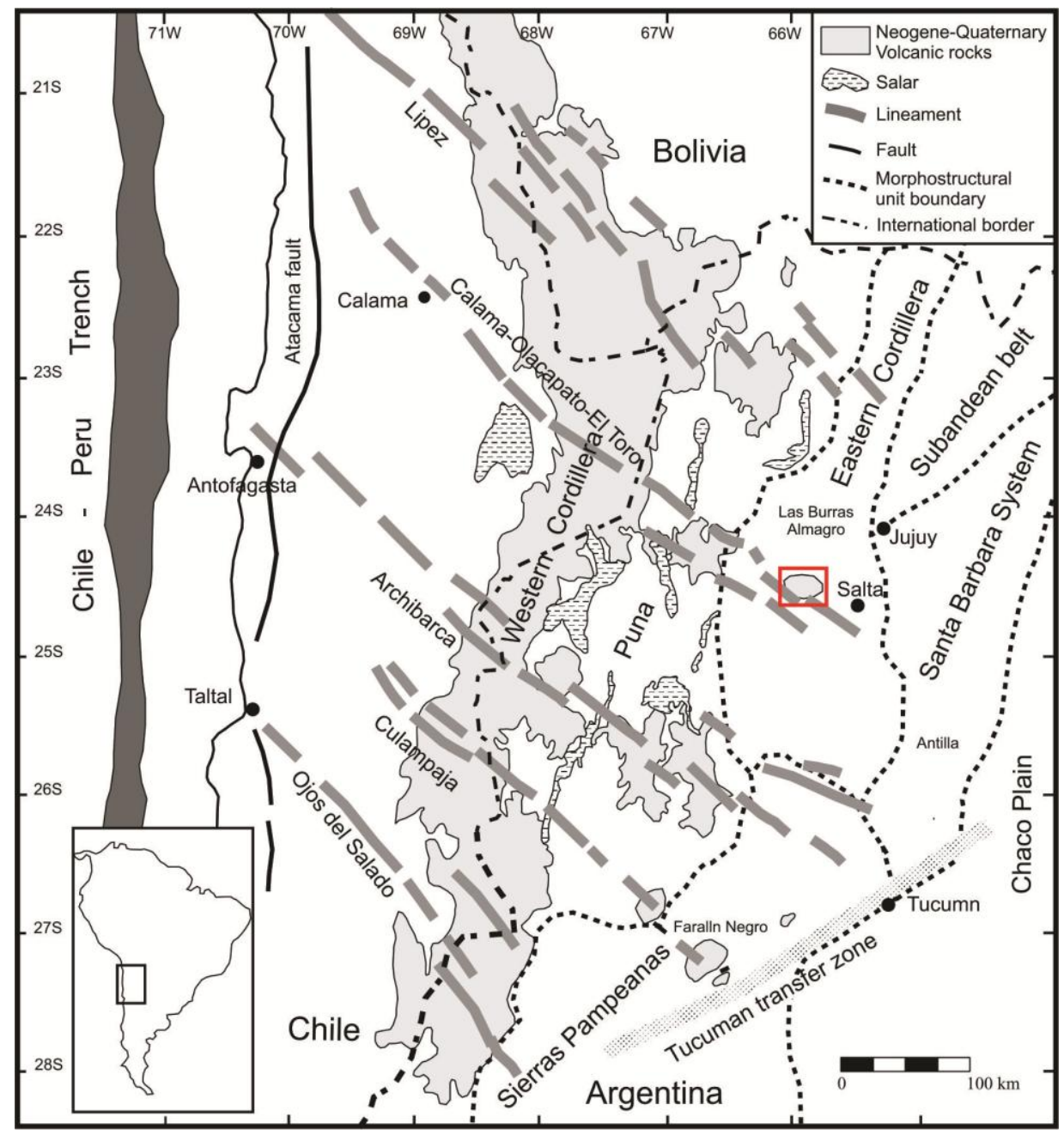

Figura 1.2 - Representação esquemática das províncias geotectônicas dos Andes Centrais representando as principais unidades morfoestrututrais, a localização dos sistemas estruturais transversais e os sistemas vulcânicos do arco principal e do retroarco. Em vermelho localiza-se o depósito Pancho Árias (Adaptado de Gioncada et al., 2010).

Em aproximadamente $536 \mathrm{Ma}$, uma série de granitoides ocorrem intrusivos nas rochas metassedimentares da Formação Puncoviscana, a primeira rocha intrusiva é um monzogranito de coloração cinza. Em $526 \mathrm{Ma}$, um corpo de composição dacítica, associado a um granito vermelho, também é alojado no mesmo local. Por fim, em 517 Ma, uma série de granitos de coloração avermelhada é formada (Figura 1.3). Todos estes corpos formam o batólito Santa Rosa de Tástil, localizados ao oeste da Cordilheira Oriental (Killmurray \& Igarzábal, 1971; Bachmann et al., 1987; Hongn et al., 2003).

No Ordoviciano outro ciclo sedimentar se inicia, marcado pela deposição das rochas sedimentares do Grupo Santa Victoria, composto pelas formações Santa Rosita e Acoite, as quais formam uma megassequência de nove corpos alternados que variam de arenitos a pelitos (Moya et al., 1998 e Moya, 1999). Essa megassequência é limitada em sua porção inferior e superior por uma discordância erosiva atribuída a Fase Irúyica, que corresponderia em nível mundial a um evento 
"O Sistema Magmático do Depósito de Cu-Mo Tipo Pórfiro Pancho Árias, Cordilheira Oriental, Argentina" Rafael Bellozupko Stremel

regressivo glaci-eustático e por uma discordância atribuída a Fase Oclóyica, respectivamente (Moya et al., 1999). A sedimentação na bacia ordoviciana se estende até o Llandeiliano, até que a orogenia oclóyica gere processos de deformação que soerguem a proto-Cordilheira Oriental (Salfity et al., 1984).

A evolução da bacia distensiva cretácica é registrada em três etapas, uma inicial de pré-rift (130 Ma) com doming, responsável pelos red beds basais, além da intrusão de corpos anorogênicos alcalinos e subalcalinos, com razão $S^{87 / 86}=0,735$, indicando derivação mantélica. Seguindo de uma etapa sin-rift com depósitos que correspondem ao subgrupo Pirgua, ao qual se associa atividade vulcânica, representado por traquitos e basanitos (Viramonte \& Escayola, 1999). A última etapa da evolução desta bacia é de pós-rift, que compreende as sequências lacustres dos subgrupos Balbuena, constituído por arenitos, calcários e pelitos (80-70 Ma), e Santa Bárbara, constituído por pelitos de variadas cores, calcários e arenitos, de 60 Ma (Moreno, 1970; Hernández et al., 1999).

No Eoceno inicia-se um importante hiato referente à orogenia Incaica (49 Ma), onde se reconheceram importantes depósitos sedimentares que relatam a transição do Eoceno, caracterizado pela Formação Lumbrera, topo do Grupo Salta, para o Oligoceno, caracterizado pela Formação Anta, base do Grupo Oram. Os depósitos de calcários e pelitos da Formação Anta foram gerados devido uma ingressão marinha do Atlântico, ocorrida durante o Oligoceno-Mioceno (Russo \& Serraiotto, 1979; Bossi et al., 1999).

A Cordilheira Oriental, no período Mioceno, é formada pelas bacias Calchaquí, Lerma e Vale de Santa Maria (Bossi et al., 1999). As bacias San Pedro e Metán, formam uma única bacia de antepaís (Hernandez et al., 1999). Na bacia Calchaquí se acumularam os depósitos sinorogênicos de maior energia, enquanto na bacia de Metán depositaram-se sedimentos distais de menor energia. No Mioceno se estabeleceram os limites de Lerma e Los Gallos que separariam as bacias de Calchaquí, Lerma e Metán (Salfity et al., 1993; Galli, 1995).

No cenozoico, os Andes Centrais registram quatro períodos de formação de rochas magmáticas, as quais são separadas por três fases distróficas. A primeira ocorreu no Oligoceno Superior/ Mioceno Inferior (26-15 Ma), os representantes destes pulsos vulcânicos localizam-se preferencialmente na borda ocidental do Chile, na zona de subducção subhorizontal $\left(28^{\circ}-33^{\circ} \mathrm{S}\right)$ (Viramonte \& Coira, 1999).

O segundo período, no Mioceno Médio (15-10 Ma), é caracterizado por uma atividade vulcânica dominada pela geração de caldeiras de colapso com emissão de ignibritos, particularmente na borda oriental do Altiplano e na Cordilheira Oriental do norte do Chile e sudoeste da Bolívia (De Silva et al., 2006). Na Puna austral, há a formação de domos e rochas subvulcânicas dacíticas intrusivas no embasamento paleozoico. Os stocks Inca Viejo e Pancho Arias são algumas das mais 
"O Sistema Magmático do Depósito de Cu-Mo Tipo Pórfiro Pancho Árias, Cordilheira Oriental, Argentina" Rafael Bellozupko Stremel

importantes mineralizações metálicas deste período, e formaram-se no Mioceno Médio (Viramonte \& Coira, 1999; Sillitoe, 1977).

O terceiro período, no Mioceno Superior/Plioceno (10-3 Ma), é caracterizado por um intenso vulcanismo ignibrítico a partir de grandes caldeiras (Cerro Guacha, Pastos Grandes, Panizos, Coranzulí, Vilama, Aguas Calientes, La Pacana, Galán), as quais emitiram milhares de $\mathrm{km}^{3}$ de ignibritos (Viramonte \& Coira, 1999). O auge deste magmatismo coincide com a finalização da fase distrófica Quechua, em 10 Ma.

O quarto período magmático ocorreu a partir do Plioceno Superior e teve início na fase distrófica Diaguita (2-3 Ma), resultando em uma importante mudança no padrão tectônicomagmático. O padrão de esforços de encurtamento sofre alteração de NW-SE para E-W e de extensão de vertical para horizontal (Allmendinger, 1986). Foram geradas falhas transcorrentes e normais subparalelas na direção do eixo principal dos Andes. Esta variação gerou a emissão de basaltos e andesitos a partir de numerosos cones monogenéticos (Alonso et al., 1984). Três grupos geoquimicamente distintos foram reconhecidos: intraplaca tipo OIB, cacialcalinos ricos em potássio e shoshoníticos (Kay et al., 1984).

\subsubsection{Geologia do Complexo Magmático Las Burras-Almagro-El Toro}

O complexo magmático Las Burras-Almagro-El Toro compreende uma área de aproximadamente $800 \mathrm{~km}^{2}$, no extremo leste do sistema Calama-Olacapato-El Toro, dentro da Cordilheira Oriental (Figura 1.3). O complexo é caracterizado por sete membros litoestratigráficos, os quais são representados pela intrusão Las Burras e outros seis membros vulcânicos da Formação Almagro, subdivididos nos membros Puerta Tastil, Las Cuevas, Lampazar e Almagro A, B e C. No empilhamento Las Burras-Almagro, os produtos vulcânicos da Formação Almagro recobrem de forma discordante o embasamento representado pela Formação Puncoviscana e também a intrusão Las Burras. Os membros da Formação Almagro incluem as unidades vulcânicas primárias e os depósitos vulcanoclásticos ressedimentados, intercalados na sequência terciária clástica continental da bacia El Toro. Para a sequência da bacia El Toro, a nomenclatura utilizada foi proposta por Marrett et al. (1994), Marrett \& Strecker (2000), e Hilley \& Strecker (2005). Estes autores propuseram idades restritas para os arenitos Barres e o conglomerado Agujas (>8Ma) e para o conglomerado basal Alfarcito (8-4,17 Ma), baseados em datações radiométricas dos tufos intercalados nas sequências sedimentares. 
"O Sistema Magmático do Depósito de Cu-Mo Tipo Pórfiro Pancho Árias, Cordilheira Oriental, Argentina" Rafael Bellozupko Stremel

Membro Las Burras: As rochas intrusivas do membro Las Burras foram estudadas primeiramente por Hongn et al. (2002), que identificaram três diferentes corpos: os plútons Las Burras, Pancho Arias e La Lagunilla. Posteriormente o corpo La Lagunilla foi associado ao batólito Santa Rosa de Tastil (Mazzuoli et al. 2008). Sillitoe, 1977 em análise K/Ar indicou uma idade de 15,4 \pm 0,3 Ma para o stock Pancho Arias, porém a pervasiva alteração hidrotermal registrada na área impediu mais interpretações.

A intrusão Las Burras possui forma elíptica alongada na direção NE-SW com aproximadamente 3,5 x $7 \mathrm{~km}$ de extensão. A primeira idade obtida foi pelo método U-Pb (14,4 Ma; Hongn et al., 2002) e foi corroborada pela isócrona de três pontos Rb-Sr 14,20 $\pm 0.04 \mathrm{Ma}$ (topo da intrusão) e 14,27 $\pm 0.04 \mathrm{Ma}$ (parte intermediária da intrusão). No contato entre a intrusão e a encaixante formam-se auréolas termometamórficas de hornfels pelíticos. O corpo principal da intrusão Las Burras possui foliação magmática dada pela anisotropia mecânica, com estratificação magmática de pequena escala ressaltada pelo teor de cristais de feldspato. $\mathrm{O}$ espaçamento da foliação varia de escala centimétrica a métrica e é concordante com a direção de elongação NE do corpo.

A deformação em torno da intrusão é representada por falhas, fraturas extensionais, diques e dobras. As principais estruturas são falhas do tipo strike-slip com direção N-S e NW-SE. As falhas N-S são dextrais e localizam-se ao longo do Rio Toro Valley, entre Finca El Toro e Pancho Arias. Estas falhas dextrais estão associadas às falhas sinistrais NE-SW e as dobras concêntricas com orientadas segundo NW-SE. A maioria destas falhas são encontradas também nas rochas metassedimentares da Formação Puncoviscana. A deformação relacionada à estas falhas concentramse em discretas zonas que não possuem mais de $10 \mathrm{~m}$. As falhas NW-SE são sinistrais e encontramse preferencialmente na Formação Puncoviscana, ao longo da quebrada Laguinilla, porém observamse também no stock Las Burras ao longo do vale Rio Toro. Os dois conjuntos de falhas (N-S dextral e NW-SE sinistral) estão relacionados ao contexto de cisalhamento simples decorrente de uma compressão ENE-WSW, Sylvester (1988).

A evidencia de reativação das estruturas N-S e principalmente das NW-SE com cinemáticas extensionais, formam falhas normais e transtensionais, sendo que o conjunto de fraturas extensionais NW-SE estão associadas a uma discreta mineralização.

Em relação a sua composição as rochas da intrusão Las Burras possuem teor em sílica que varia de 54-65\% e composições que variam de monzogabro a monzogranito, segundo a classificação normativa proposta por Streckeisen \& Le Maitre (1979). A maioria das rochas máficas apresenta caráter transicional e abrangem a curva de Irvine \& Baragar (1981), enquanto amostras intermediárias e ricas em sílica caem no campo de sub-alcalinas e classificam-se como granitoides metaluminosos calcialcalinos. 
"O Sistema Magmático do Depósito de Cu-Mo Tipo Pórfiro Pancho Árias, Cordilheira Oriental, Argentina" Rafael Bellozupko Stremel

Em $70 \%$ da área total aflorante, a rocha é um monzodiorito composto por plagioclásio, augita, e magnésio-hornblenda marrom-verde que ocorre como produto da substituição do piroxênio. As variedades do monzogranito apresentam feldspato alcalino e quartzo em conjunto com plagioclásio, anfibólio e biotita. Minerais acessórios comuns são esfeno, titano-magnetita, zircão e apatita. Dispersos na intrusão, particularmente nas estruturas SW, há enclaves angulares e arredondados dos metassedimentos encaixantes, sua assembleia mineral é composta de K-feldspato, clinopiroxênio, anfibólio, biotita e em menores proporções quartzo, zircão, apatita e óxidos de ferro e titânio.

Em diagramas ${ }^{87} \mathrm{Sr} /{ }^{86} \mathrm{Sr} v s{ }^{143} \mathrm{Nd} /{ }^{144} \mathrm{Nd}$, as rochas do corpo Las Burras apresentaram baixa razão isotópica de $\mathrm{Sr}$ e elevada de $\mathrm{Nd}$, definindo um trend negativo. As amostras dos afloramentos do sul do campo definem um grupo com relativo baixa razão isotópica de $\mathrm{Nd}$ e elevada de $\mathrm{Sr}$ $\left({ }^{87} \mathrm{Sr} /{ }^{86} \mathrm{Sr} \sim 0,705 ;{ }^{143} \mathrm{Nd} /{ }^{144} \mathrm{Nd} \sim 0,5126\right)$. Essas razões são distintas em relação as amostras do centronorte do corpo que possuem razões de ${ }^{87} \mathrm{Sr} /{ }^{86} \mathrm{Sr} \sim 0,705$ e ${ }^{143} \mathrm{Nd} /{ }^{144} \mathrm{Nd} \sim 0,5127$. Essas rochas possuem fraca relação isotópica positiva entre sílica e Sr e correlação negativa entre sílica e $\mathrm{Nd}$.

A intrusão Las Burras possui foliação subparalela, interpretada como expressão mecânica de uma descontinuidade no fluxo. (Marre, 1986; Paterson \& Vermon, 1995; Hrouda et al., 1999; Dietl \& Koyi, 2002). Portanto a direção e o mergulho da foliação indicam a direção do fluxo de magma dentro do corpo. A foliação subparalela ao contato com a rocha hospedeira sugere fluxo lateral no topo da intrusão. As foliações NE-SW subverticais no núcleo da parte mais ao sul sugere fluxo vertical. Estas direções de fluxo, juntamente com a forma tabular do corpo, sugerem que a intrusão é um lacólito, elongado na direção NE-SW. As diferenças na composição isotópica de Sr e Nd entre os afloramentos do sul e os centrais podem indicar distintas quantidades de magmas alimentando o lacólito, com o primeiro magma possuindo elevado $\mathrm{Nd}$ e baixo $\mathrm{Sr}$, enquanto os demais magmas (evoluídos e contaminados) formaram a porção inferior. O trend NE-SW do corpo está cinematicamente relacionado com as falhas dextrais N-S ativas no Mioceno. Estas falhas criaram uma zona extensional localizada, favorecendo a ascensão NE-SW destes magmas, que primeiramente formaram um sill, porém a prolongada injeção de magma gerou um lacólito. A tectônica strike-slip da área pode ser interpretada com um desvio da convergência E-W que controlou o desenvolvimento das zonas de tensão nas margens da bacia El Toro. (Cladouhos et al., 1994; Marrett et al., 1994; Marrett \& Strecker, 2000; Acocella et al., 2007).

Membros Almagro-El Toro: A unidade vulcânica mais velha, membro Puerta Tastil $(12,78 \pm 0,19$ Ma) consiste em fluxo de lavas interdigitados com arenitos avermelhados e siltitos (Marrett \& 
Strecker, 2000; Hilley \& Strecker, 2005). O membro Las Cuevas (11,12 \pm 0,17 Ma) é representado por brechas vulcânicas intercaladas com argilas estratificadas e brecha de púmice, este membro sobrepõe em não conformidade o granodiorito cinza Santa Rosa de Tastil é coberto discordantemente por arenitos e conglomerados não vulcânicos Alfarcito (Marrett \& Strecker, 2000; Hilley \& Strecker, 2005, Figura ).

O membro Lampazar $(7,87 \pm 0,17 \mathrm{Ma})$ consiste em uma camada sinvulcânica de andesito intrusiva em brecha vulcanoclástica, conglomerado e arenitos. O membro Almagro A $(7,20 \pm 0,11$ Ma) consiste em brechas vulcânicas monomíticas, intercaladas em arenitos e conglomerados vulcanoclásticos polimíticos. O membro Almagro B alojou-se em um espaço curto de tempo, com idade $\operatorname{K} / \operatorname{Ar} 7,37 \pm 0,11 \mathrm{Ma}, 7,35 \pm 0,11 \mathrm{Ma}, 7,33 \pm 0,11 \mathrm{Ma}$, e 6,95 \pm 0,10 Ma e consiste em fluxos de lavas andesíticas, domos de lavas, brechas vulcanoclásticas e conglomerados. A unidade vulcânica mais jovem é representada pelo membro Almagro C $(6,70 \pm 0,10$ a 6,39 $\pm 0,10$ Ma) e é caracterizada por domos de lavas andesíticas, traquidacíticas e dacíticas, além de fluxos de lava e criptodomos com diques alimentadores com direções N-S e WNW-ESE. 
"O Sistema Magmático do Depósito de Cu-Mo Tipo Pórfiro Pancho Árias, Cordilheira Oriental, Argentina" Rafael Bellozupko Stremel

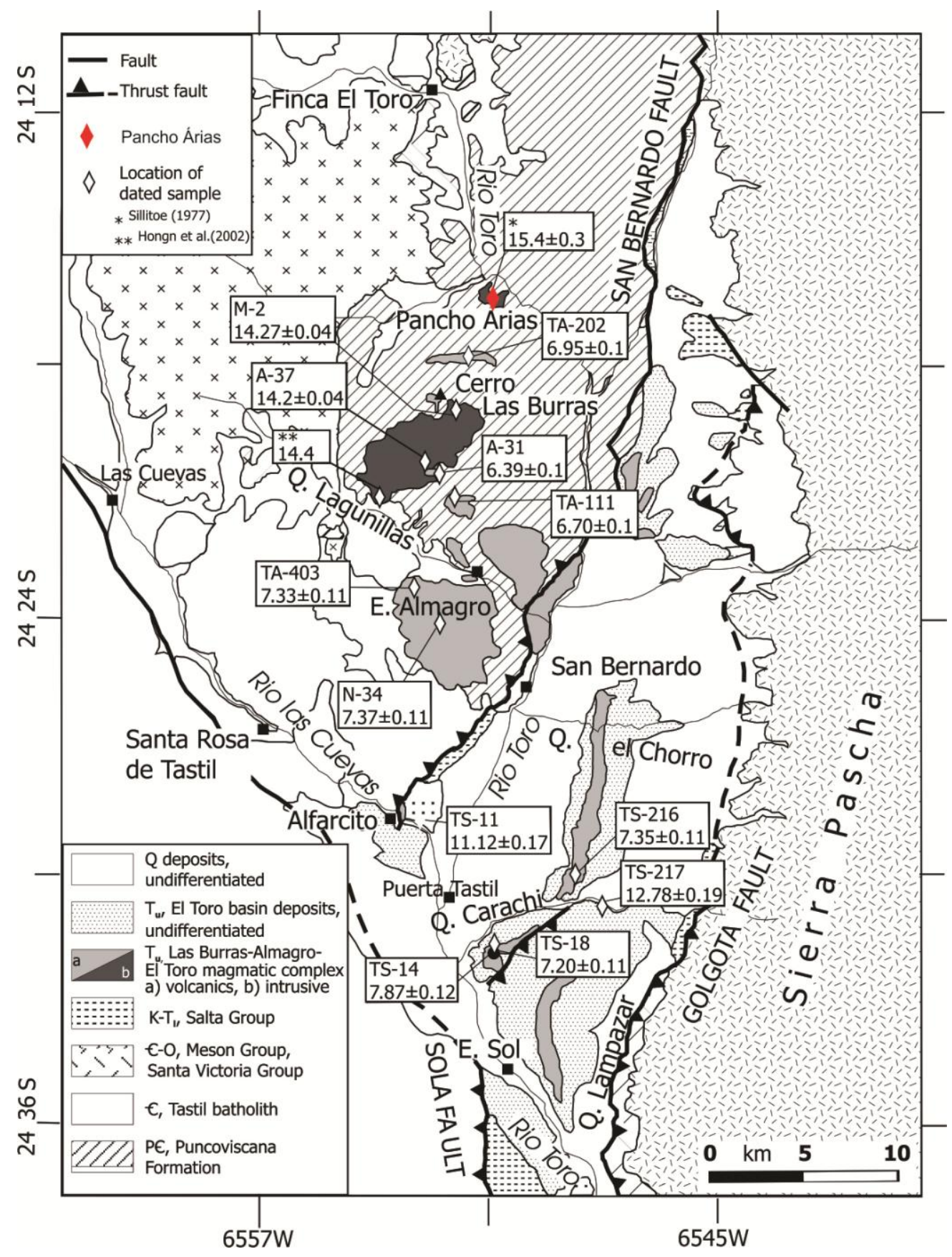

Figura 1.3 - Contexto geológico do complexo magmático Las Burras-Almagro-El Toro e bacia El Toro, localizando as datações já realizadas na área e suas seções estratigráficas (Adaptado de Mazzuoli, et al., 2008).

As rochas do membro Almagro são subalcalinas, com teor em sílica que varia de 53 a $66 \%$ definindo um trend calcialcalino de basalto andesito a dacito. As rochas dos membros Puerta Tastil, Las Cuevas, Lampazar e Almagro A e B são andesitos porfiríticos, com fenocristais de plagioclásio e anfibólio. Em algumas lavas (Lampazar, Almagro A e B) o clinopiroxênio é o fenocristal máfico dominante. Apatita e óxidos de Fe e Ti são os minerais acessórios mais comuns.

Feições de desequilíbrio ocorrem nas rochas vulcânicas do membro Almagro, como enclaves de magmas máficos que contém fenocristais de olivina e clinopiroxênio nos magmas andesíticos de 
"O Sistema Magmático do Depósito de Cu-Mo Tipo Pórfiro Pancho Árias, Cordilheira Oriental, Argentina" Rafael Bellozupko Stremel

Puerta Tastil e Almagro B, gerando feições de microlitos, indicando processo de mingling (Bacon, 1986; Snyder, 2000; Perugini \& Poli, 2000).

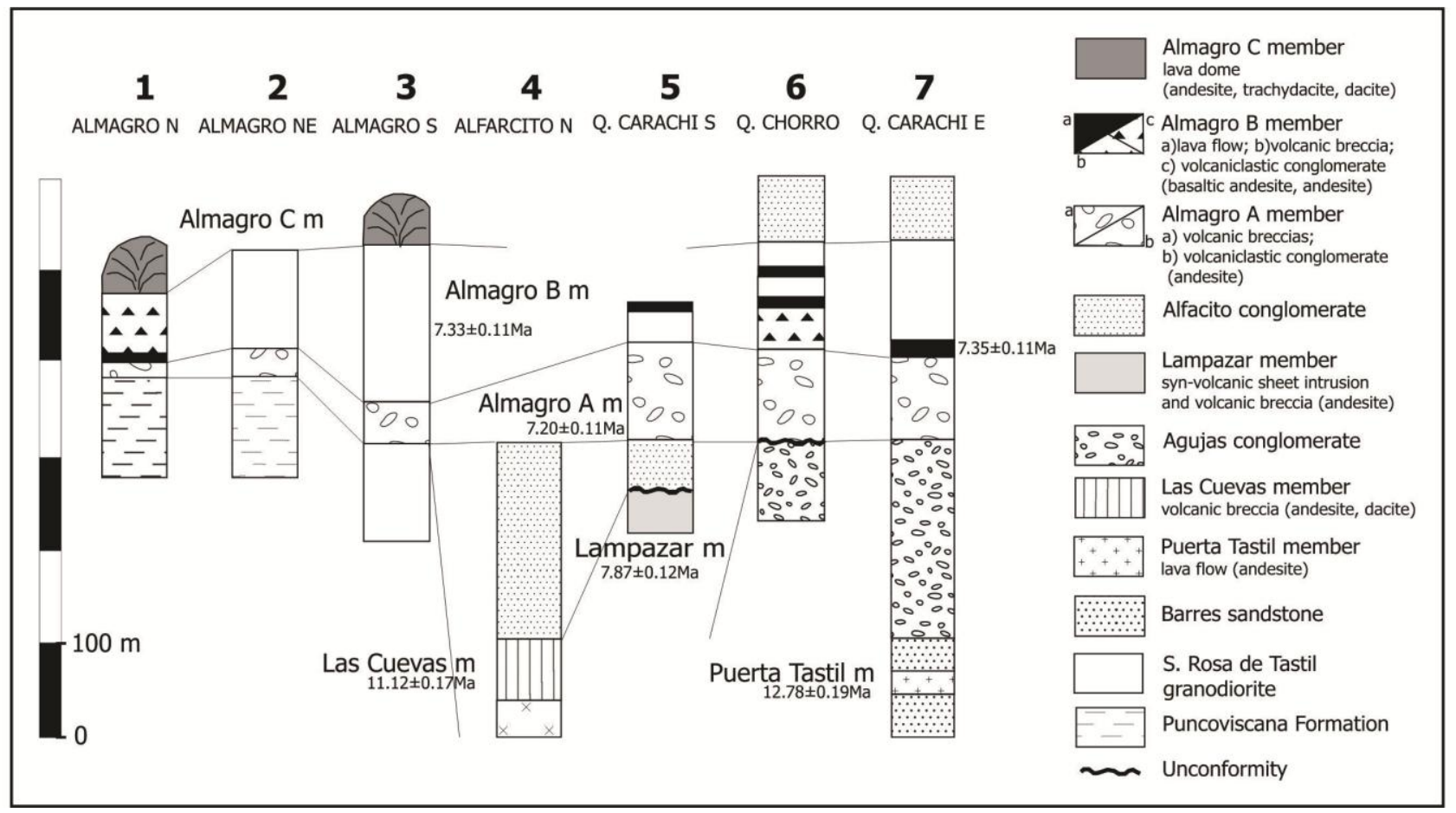

Figura 1.4 - Seções estratigráficas na região do complexo Las Burras-Almagro-El Toro, exibindo correlação dos membros vulcânicos Almagro e da bacia El Toro (Adaptado de Mazzuoli et al., 2008).

A geoquímica das rochas do complexo possuem elevado conteúdo $\mathrm{K}_{2} \mathrm{O}$ e baixo $\mathrm{MgO}$ em relação as vulcânicas. $\mathrm{Al}_{2} \mathrm{O}_{3}$ e $\mathrm{Na}_{2} \mathrm{O}$ exibem correlação positiva com $\mathrm{SiO}_{2}$ para as rochas do membro Almagro, enquanto as rochas do Las Burras apresentam padrão bem definido. $\mathrm{CaO}$ e $\mathrm{TiO}_{2}$ possuem comportamento compatível e diminuem com a sílica. Os dois grupos de rochas apresentam diferentes trends com o aumento de sílica nos diagramas com elementos traço, os membros Las Burras e Puerta Tastil possuem o maior conteúdo de $\mathrm{Rb}$, o menor e constante em $\mathrm{Ba}$ e semelhante e disperso em $\mathrm{Sr}$, quando comparado as unidades mais jovens do membro Almagro. $\mathrm{O} \mathrm{Nb}$ mostra comportamento nas rochas do Las Burras e Puerta Tastil e trend oposto nas mais novas. As razões ${ }^{87} \mathrm{Sr} /{ }^{86} \mathrm{Sr}$ das rochas vulcânicas variam de 0,70674 a 0,70873 e ${ }^{143} \mathrm{Nd} /{ }^{144} \mathrm{Nd}$ de 0,5124 a 0,51234 , com a unidade Almagro B apresentando a menor razão de Sr e maior de Nd (Mazzuolli et al., 2008). 
"O Sistema Magmático do Depósito de Cu-Mo Tipo Pórfiro Pancho Árias, Cordilheira Oriental, Argentina" Rafael Bellozupko Stremel

\section{CAPÍTULO 2}

\subsection{Geologia do Depósito Cu-Mo Tipo Pórfiro Pancho Árias}

A geologia do depósito Pancho Árias é caracterizada pela presença de quatro membros magmáticos intrusivos em um embasamento composto por rochas metassedimentares, neoproterozoicas da Formação Puncoviscana.

As rochas encaixantes estão afetadas por intensa silicificação, resultando na geração de densa venulação e estruturas do tipo stockwork. Os membros magmáticos são compostos por dois pórfiros andesíticos, um a biotita (PAB) e outro a anfibólio (PAA), os quais são acompanhados por diversos corpos de brechas distribuídos por todo o âmbito do prospecto. Os demais membros magmáticos são representados por um stock de composição quartzo monzodiorítico e um sistema de diques e sills riodacíticos a traqui-andesíticos.

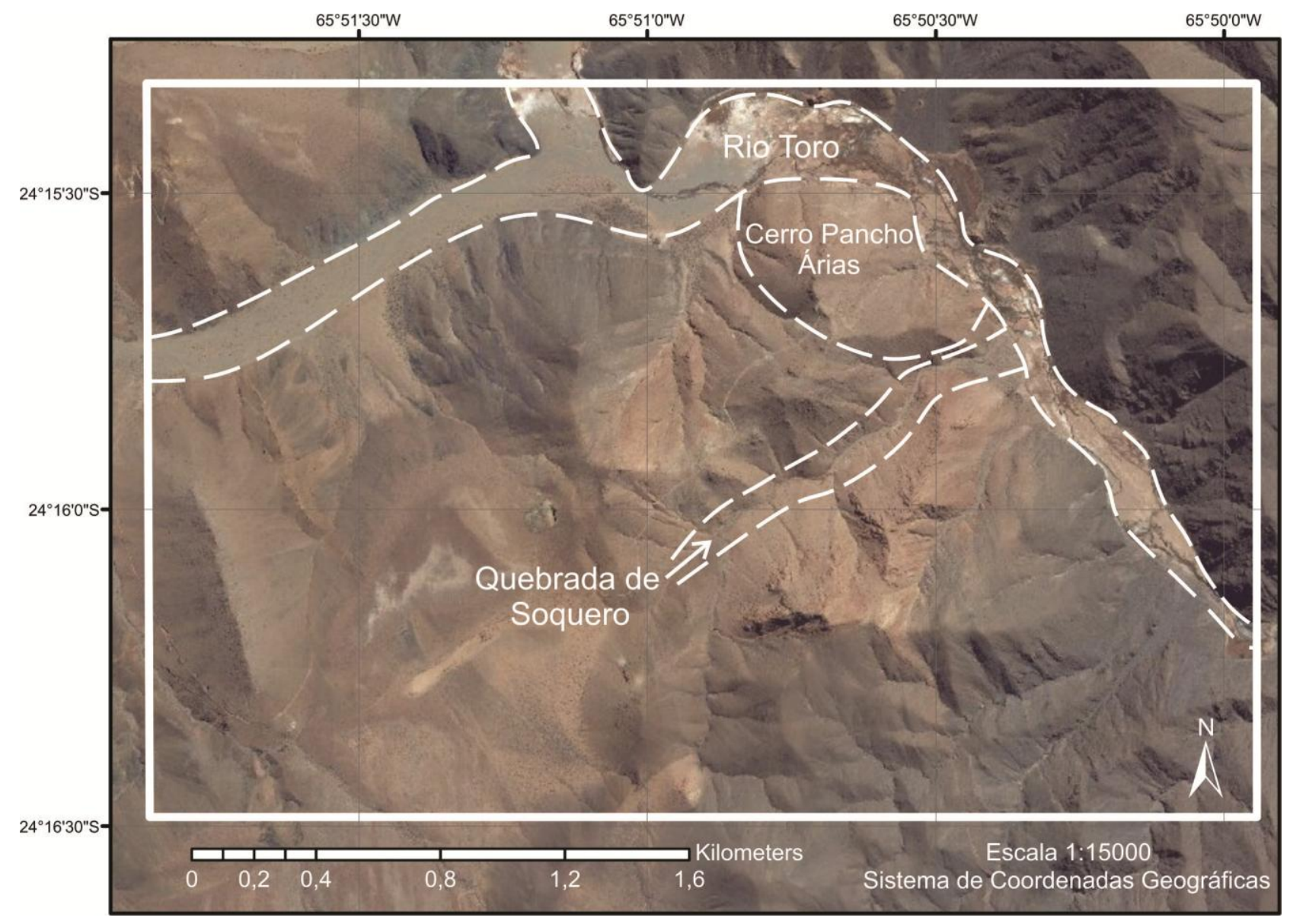

Figura 2.1- Imagem aérea do depósito Pancho Árias, ressaltando os principais setores do depósito. 
"O Sistema Magmático do Depósito de Cu-Mo Tipo Pórfiro Pancho Árias, Cordilheira Oriental, Argentina" Rafael Bellozupko Stremel

\subsubsection{Formação Puncoviscana}

As rochas desta unidade são caracterizadas por um conjunto de rochas metassedimentares (pelíticas a areníticas) de granulação fina a média e cor cinza-escuro. Estas rochas mostram-se intercaladas em pacotes centimétricos a métricos, basculados a levemente dobrados, distribuídos em torno dos pórfiros andesíticos e do stock quartzo- monzodiorito, sendo atravessado pelo sistema de diques e sills riodacíticos a traqui-andesíticos (Figuras 2.2d e 2.3). São ainda marcadas por zonas de alteração hidrotermal dos tipos propilítica e potássica, as quais hospedam vênulas contendo mineralizações (Figura 2.2b).
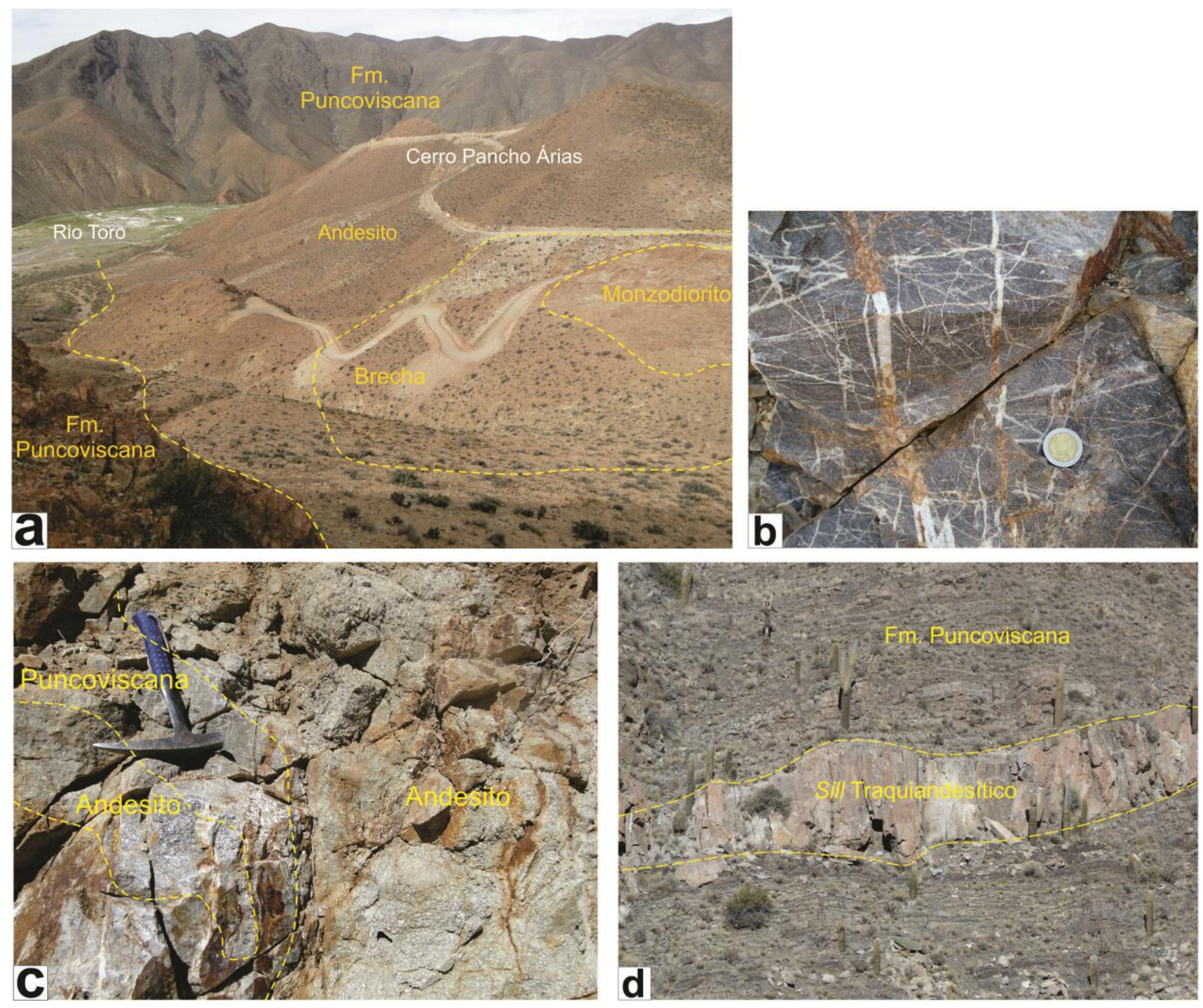

Figura 2.2 a) relações e contatos entre os membros magmáticos, brechas e rocha encaixante da área. b) detalhe do denso stockwork que afeta as rochas metassedimentares da Formação Puncoviscana. c) detalhe das relações de intrusão entre os pórfiros andesíticos e as rochas metassedimentares da rocha encaixante. d) sill na Formação Puncoviscana. 

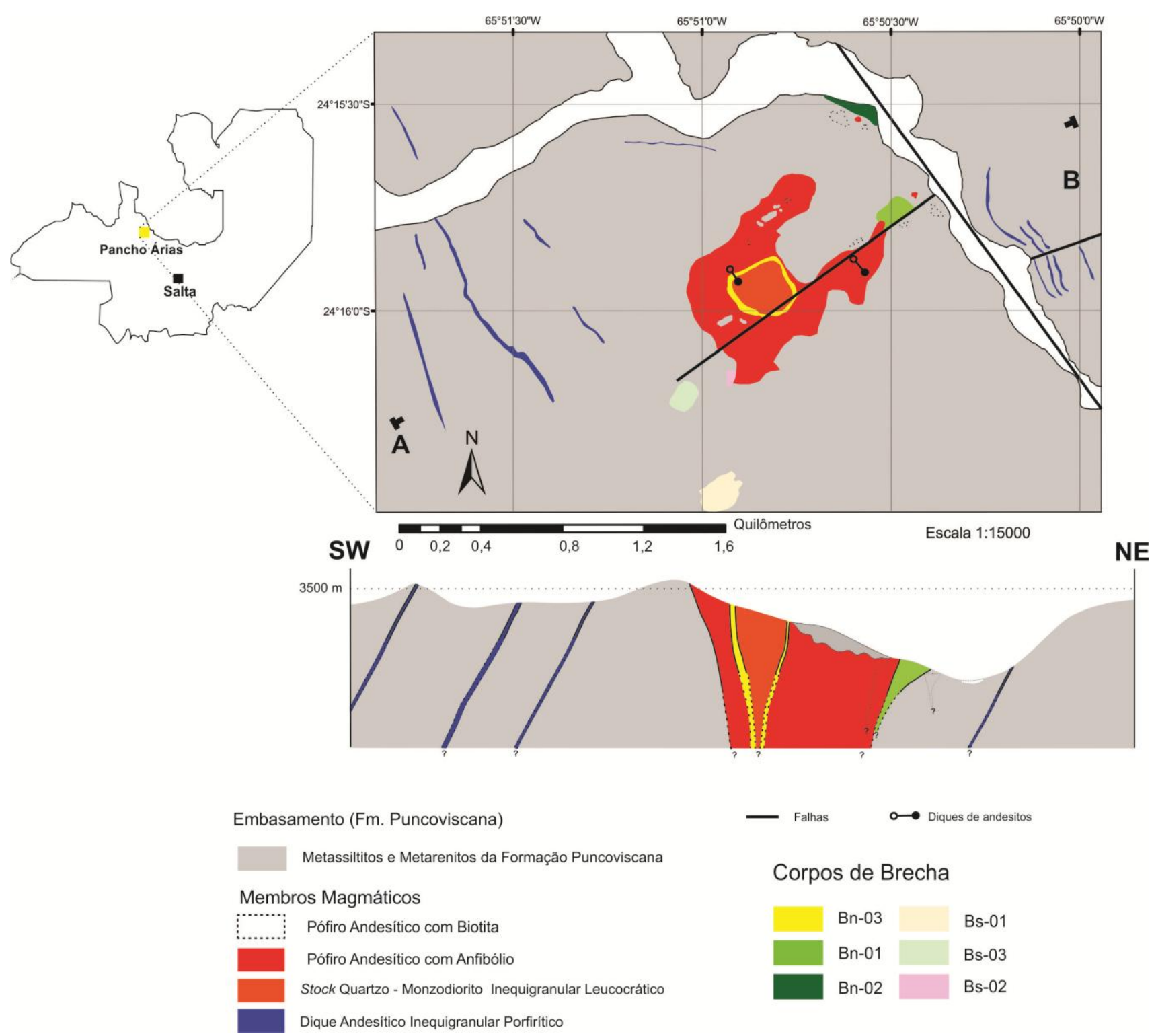

Figura 2.3- Mapa e perfil geológico do depósito Pancho Árias.

\subsubsection{Membros Magmáticos}

Pórfiros Andesíticos - essas rochas hospedam parte da mineralização Cu-Mo no depósito Pancho Árias, localizadas no setor central da área de estudo (Figura 2.3).

O pórfiro andesítico biotítico apresenta arranjo textural porfirítico ressaltado por fenocristais de plagioclásio, biotita e quartzo imersos em uma matriz de cor cinza-escura e de granulação fina a afanítica. Ocorre sob a forma de plugs e diques no setor norte da área, próximo ao rio Toro, atravessando as rochas metassedimentares do embasamento. Entretanto, no setor central da área, esse pórfiro ocorre sob a forma interdigitada entre o embasamento e o outro pórfiro andesítico, bem como 
"O Sistema Magmático do Depósito de Cu-Mo Tipo Pórfiro Pancho Árias, Cordilheira Oriental, Argentina" Rafael Bellozupko Stremel

sob a forma de blocos irregulares centimétricos inclusos no pórfiro com anfibólio (Figuras 2.2a 2.2c e 2.3).

O arranjo microtextural porfirítico desse membro magmático é ressaltado por fenocristais de plagioclásio, quartzo e biotita dispersos em matriz microcristalina composta predominantemente por agregados de quartzo, plagioclásio e biotita, além de titanita, zircão, pirita, calcopirita, ilmenita e magnetita como acessórios (Figura 2.2a).

Quanto aos fenocristais, o plagioclásio $\left(\mathrm{An}_{42-53}\right)$ é a fase mineral dominante, com 20 a 30\% da composição modal das amostras, ocorrendo sob a forma de fenocristais euédricos a subédricos, com tamanho entre 1 e 4 mm, moderadamente fraturados, exibindo marcante zonação interna oscilatória e característico maclamento polissintético, além de discreta descalcificação, principalmente nas zonas ricas em Ca, marcada pela geração de agregados microcristalinos de mica branca (Figuras 2.4b, 2.4d). O quartzo compõe entre $2 \%$ e $5 \%$ das amostras, são subedrais, exibem tamanho entre 0,7 e 3 mm, extinção ondulante, bordas parcialmente corroídas e com feições de golfo de corrosão (Figura 2.4c), diagnóstico reabsorção através da reação cristal-melt. Estão moderadamente fraturados e cujas fraturas estão parcialmente preenchidas por óxi-hidróxidos de ferro. A biotita, por sua vez, representa entre 1-4\% das amostras, são subédricos a euédricos, com tamanho em torno de 1,5 mm, exibem pleocroísmo que varia de amarelo pálido a marrom-escuro (Figuras 2.4e, 2.4f).

$\mathrm{Na}$ matriz, a trama quartzo-feldspática representa a fase mineral principal, ocorrendo sob a forma de agregados microcristalinos anedrais a subedrais, com cristais menores a $1 \mathrm{~mm}$, exibindo feições de recristalização com geração de subgrãos. A biotita ocorre sob a forma de cristais subédricos e em aglomerados disseminados na trama quartzo-feldspática, com tamanho entre 0,2 e $0,5 \mathrm{~mm}$. Os minerais acessórios ocorrem disseminados na trama quartzo-feldspática, porém estão associados preferencialmente aos aglomerados de biotita, ocorrendo sob a forma de cristais subédricos a euédricos. 

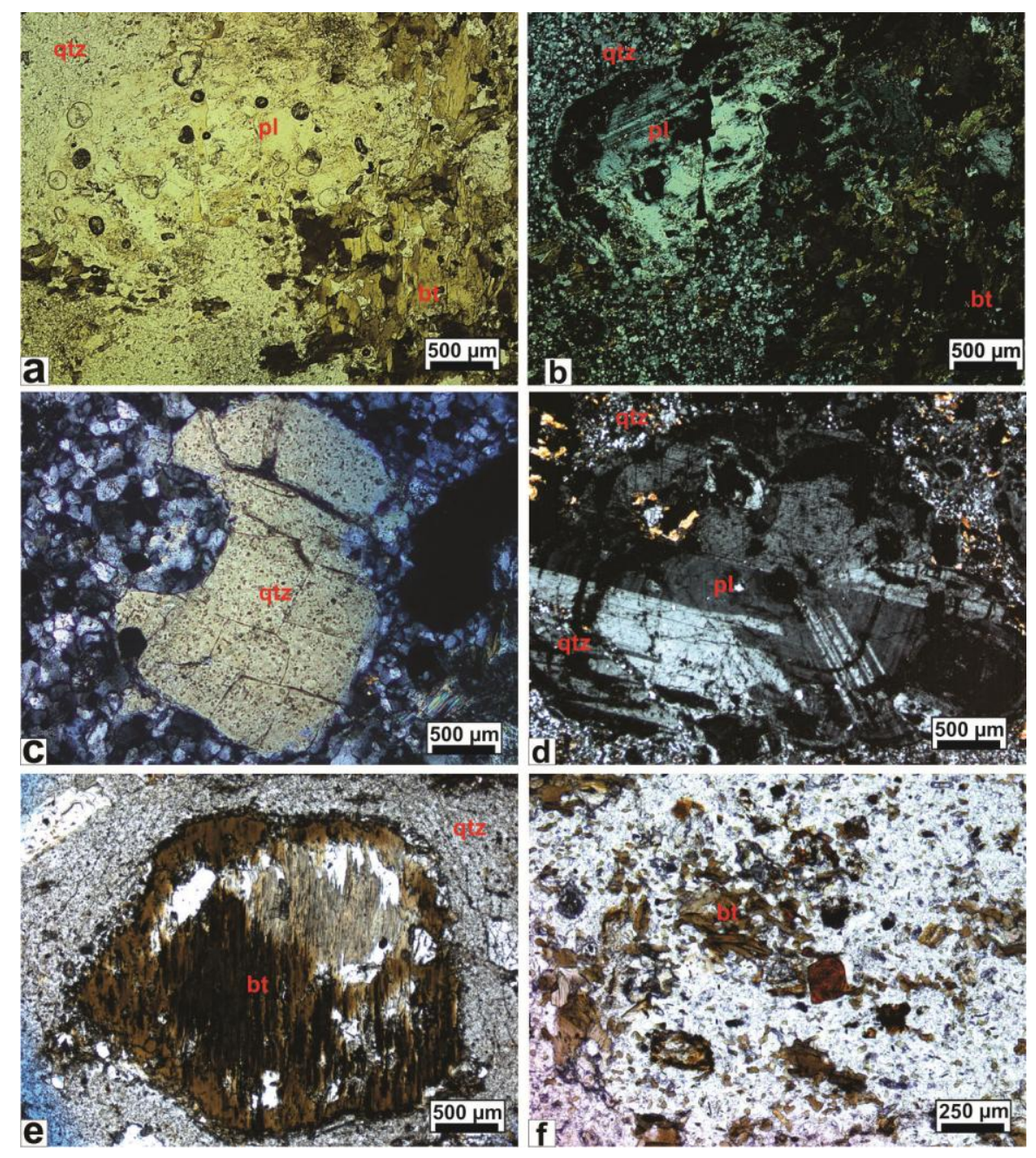

Figura 2.4 - Micrografias ressaltando o arranjo microtextural do pórfiro andesítico com biotita, nicóis paralelos: N//, nicóis cruzados: $\mathrm{NX} . \mathrm{Qtz}=$ quartzo, $\mathrm{Bt}=$ biotita, $\mathrm{Pl}=$ plagioclásio. a) $4 \mathrm{x}, \mathrm{N} / /$. Arranjo microterxtural porfirítico, ressaltando fenocristais de plagioclásio e biotita (AND 04). b) 4x, NX. Arranjo microtextural porfirítico, destacando plagioclásio com zonação composicional (AND 04). c) 4x, N//. Detalhe de fenocristal de quartzo exibindo golfo de corrosão (PA 237). d) 4x, NX. Detalhe de um fenocristal de plagioclásio zonado e com reação de borda com o melt (An${ }_{35}$ ) (PA 101). e) 4x, N//. Detalhe de fenocristal de biotita primária, exibindo reação de borda com o melt (PA 237). f) 10x, N//. Detalhe de aglomeração de grãos subedrais de biotita e da trama quartzo-feldspática que compõe a matriz (PA 101).

Já o pórfiro andesítico com anfibólio, por sua vez, apresenta arranjo textural porfirítico ressaltado por fenocristais de plagioclásio, anfibólio \pm biotita e quartzo, imersos em matriz de cor cinza claro e granulação fina a afanítica. Esse membro magmático é dominante no setor central da área, o qual corresponde aos chamados Cerro Pancho Árias e Quebrada De Soquero (Figura 2.1). Hospeda xenólitos centimétricos e blocos irregulares métricos (tipo roof pendant) das rochas metassedimentares encaixante, além de ocasionais fragmentos do outro pórfiro andesítico (Figura 2.2c). Esse membro magmático hospeda ainda halos incipientes de alteração hidrotermal do tipo sericítico que se sobrepõe a alteração potássica. 
"O Sistema Magmático do Depósito de Cu-Mo Tipo Pórfiro Pancho Árias, Cordilheira Oriental, Argentina" Rafael Bellozupko Stremel

$\mathrm{O}$ arranjo microtextural porfirítico desse pórfito andesítico se assemelha ao outro pórfiro, sendo ressaltado por fenocristais de plagioclásio, anfibólio, quartzo e biotita dispersos em matriz composta por agregados microcristalinos de quartzo, plagioclásio e biotita, além de titanita, zircão, epidoto, pirita, magnetita e ilmenita como minerais acessórios (Figura 2.5c).

Dentre aos fenocristais, o plagioclásio $\left(\mathrm{An}_{45-50}\right)$ é a fase mineral dominante, com $25-30 \%$ da composição modal, ocorre sob a forma de fenocristais subédricos a euédricos límpidos, com tamanho entre 1 e $5 \mathrm{~mm}$, exibindo marcante zonamento composicional oscilatória e em forma esponjosa, cujas zonas mais ricas em $\mathrm{Ca}$ se mostram substituídas por agregados microcristalinos de mica branca \pm argilominerais. Exibem ainda coroas de reação com o melt, as quais são marcadas pelo desenvolvimento de microcordões de quartzo (Figuras 2.5d e 2.5e). Esses fenocristais estão pouco a moderadamente fraturados, cujas fraturas estão frequentemente preenchidas por mica branca. Os fenocristais de anfibólio correspondem a 10-12\% da composição modal das amostras, são subédricos a euédricos, exibem bordas denteadas, produtos da reação com o melt, e, em sua maioria, estão parcial a totalmente substituídos por cristais anedrais de biotita (Figura 2.5f). Os fenocristais de quartzo correspondem entre $5-7 \%$ da composição das rochas, ocorrem como cristais subarredondados, com tamanho entre 0,5 a $1,5 \mathrm{~mm}$, possuem marcante extinção ondulante, com bordas corroídas e feições de reabsorção. A biotita, por sua vez, compõe entre 1-2\% das rochas, ocorre sob a forma de cristais euédricos com tamanho de 0,5 a $2 \mathrm{~mm}$, possui pleocroísmo que varia de amarelo pálido a marrom-escuro, bordas de reação e microinclusões de hábito acicular distribuídas ao longo dos planos de clivagem (Figura 2.5f).

A matriz é composta principalmente por agregados quartzo-feldspáticos, com cristais de formatos anedrais a subedrais, exibindo contatos poligonizados, cujos tamanhos variam entre $0,1 \mathrm{e}$ $0,3 \mathrm{~mm}$. Os cristais de biotita são anedrais a subedrais, ocorrem em aglomerados disseminados na trama quartzo-feldspática, cujos tamanhos variam entre 0,1 e $0,5 \mathrm{~mm}$. Os minerais acessórios ocorrem igualmente disseminados na matriz, porém preferencialmente associados aos aglomerados de biotita, ocorrendo sob a forma de cristais subédricos a euédricos. 
"O Sistema Magmático do Depósito de Cu-Mo Tipo Pórfiro Pancho Árias, Cordilheira Oriental, Argentina" Rafael Bellozupko Stremel
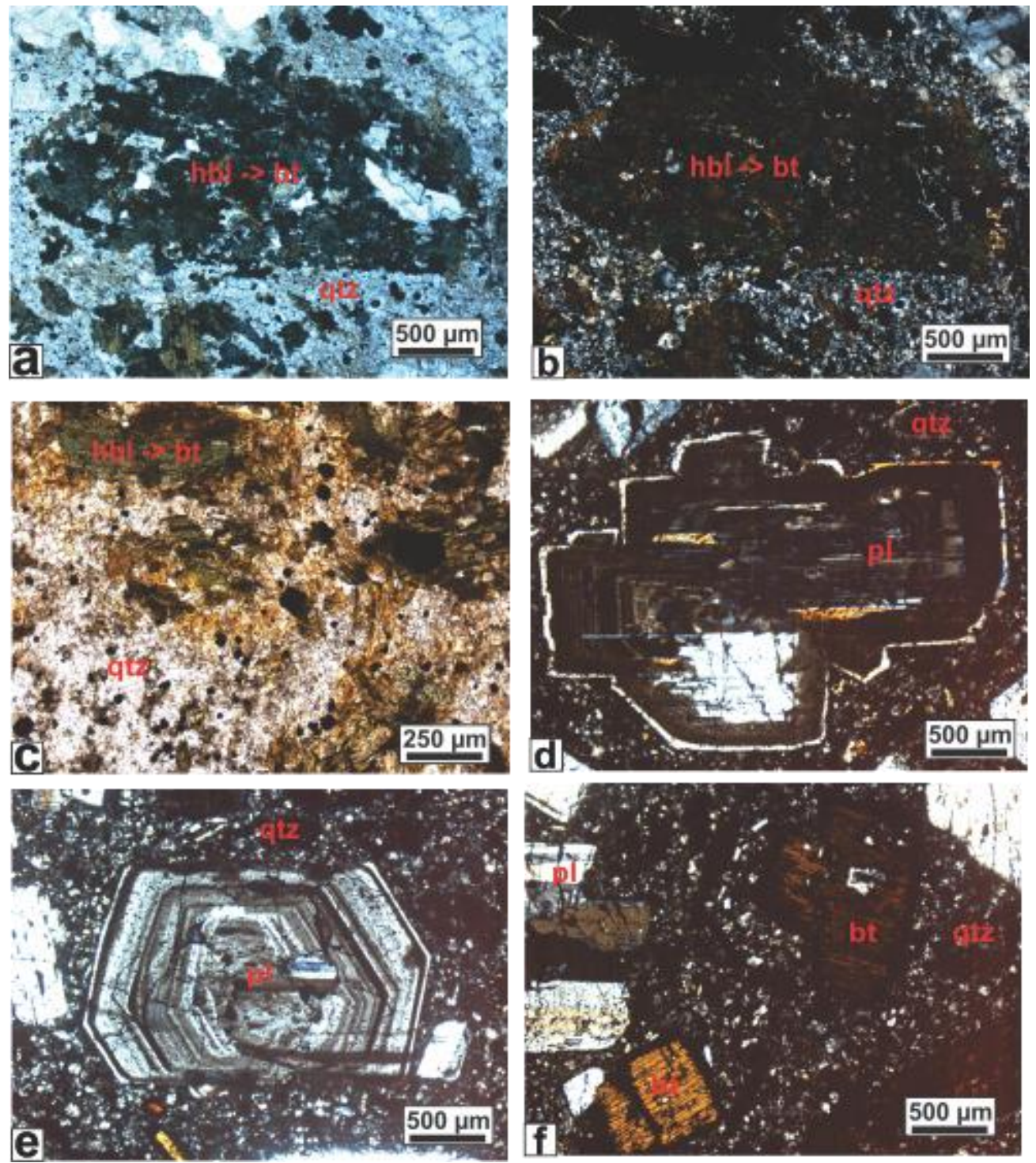

Figura 2.5- Micrografias do pórfiro andesítico com anfibólio, nicóis paralelos: N//, nicóis cruzados: NX. Qtz = quartzo, $\mathrm{Bt}=$ biotita, $\mathrm{Pl}=$ plagioclásio, $\mathrm{Hbl}=$ hornblenda. a) $4 \mathrm{x}, \mathrm{N} / /$. Detalhe de fenocristal da seção prismática de pseudomorfo de hornblenda substituído para biotita e de matriz da rocha, composta por mosaico de quartzo (MD 20). b) a) 4x, NX. Detalhe de fenocristal da seção prismática de pseudomorfo de hornblenda substituído por biotita e de matriz da rocha, composta por mosaico de quartzo (MD 20). c) 10x, N//. Textura ressaltada por hornblenda com substituição para biotita, biotita primária imersos em matriz composta predominantemente por quartzo. (MD 20). d) 4x, NX. Detalhe de fenocristal subedral de plagioclásio com zonação composicional e reação de borda com o melt, resultando na formação de cordão de quartzo (PA 102). e) 4x, NX. Detalhe de fenocristal de plagioclásio com zonação composicional (PA 102). f) 4x, NX. Textura da fase magmática P2, composta por fenocristais de plagioclásio, biotita e quartzo dispersos em matriz composta por mosaico de quartzo (PA 102).

Stock quartzo monzodiorítico - Na porção central da área, logo ao sul do Cerro Pancho Árias (Figuras 2.1, 2.2a e 2.3), aflora um stock sub-circular em planta, com rochas de cor brancoacinzentado a cinza-esbranquiçado, arranjo textural inequigranular a porfirítico de granulação média, formado por fenocristais de feldspatos, hornblenda e biotita disseminados em matriz aproximadamente equigranular e a base de quartzo, plagioclásio e biotita. 
"O Sistema Magmático do Depósito de Cu-Mo Tipo Pórfiro Pancho Árias, Cordilheira Oriental, Argentina" Rafael Bellozupko Stremel

Esse membro magmático não apresenta marcante alteração hidrotermal e sua relação de contato com os pófiros andesíticos, bem como com as rochas metassedimentares da Formação Puncoviscana, é intrusivo (Figura 2.3). Segundo Martin (2007), tal natureza intrusiva é caracterizada pela presença de xenólitos e estrutura do tipo roof pendant.

Petrograficamente, esse membro magmática exibe arranjo holocristalino inequigranular, a porfirítico, composto por fenocristais de plagioclásio, biotita e hornblenda em matriz equigranular composta por quartzo, plagioclásio, microclínio e biotita, contendo titanita, zircão e ilmenita como fases acessórias (Figuras 2.7a, 2.7b). Análise modal da fase mineral essencial permitiu classificar essa rocha, em diagrama QAP, como quartzo monzodiorito (Figura 2.6).

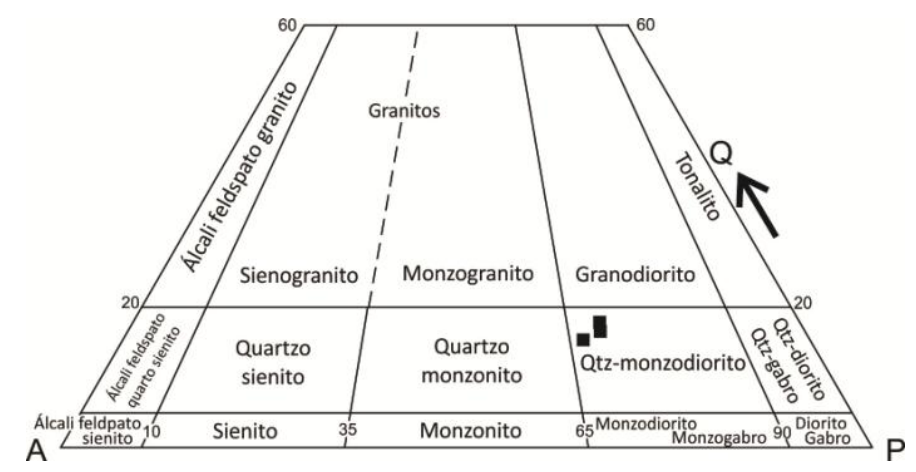

Figura 2.6- Diagrama QAFP de classificação de rochas plutônicas, proposto por Streckeisen, 1976.

Os fenocristais de plagioclásio $\left(\mathrm{An}_{35-42}\right)$ compõem 20-22\% do volume modal, são subédricos a euédricos, com tamanho entre 1 e $4 \mathrm{~mm}$, exibem marcante zonamento composicional oscilatório e geminação polissintética (Figura 2.7b), cujos planos são normalmente e descontínuos e ocasionalmente deslocados por microfraturas. Estão moderadamente fraturados e mostram ocasionais cordões de sericita nas bordas ou aglomerados serecíticos nos núcleos dos fenocristais, associados as zonas mais ricas em Ca. O anfibólio representa $12-15 \%$ da composição modal, são euédricos a subédricos, exibem pleocroísmo que varia de amarelo pálido a verde escuro, estão parcialmente desestabilizados para clorita (Figura 2.7e), principalmente ao longo de microfraturas e planos de clivagem, e apresentam sua seção basal com $1 \mathrm{~mm}$, enquanto a seção prismática mostra tamanho de até $3 \mathrm{~mm}$ (Figura 2.7d). A biotita compõe entre 1 e 5\% do volume modal, ocorre sob a forma de cristais euédricos a subédricos, com tamanho entre 0,4 e $2 \mathrm{~mm}$, exibe pleocroísmo que varia de marrom-escuro a amarelo pálido e se mostram parcialmente transformadas para clorita ao longo das clivagens, resultando em pleocroísmo que varia de verde-claro a verde-escuro (Figura 2.7d).

$\mathrm{Na}$ matriz, a associação quartzo + feldspatos representam as fases minerais principais, sendo composta por grãos subedrais, com tamanho entre 0,5 e $1 \mathrm{~mm}$, de quartzo, plagioclásio e microclínio em contatos poligonizados. O quartzo compõe cerca de $70 \%$ da trama, possuem característica 
"O Sistema Magmático do Depósito de Cu-Mo Tipo Pórfiro Pancho Árias, Cordilheira Oriental, Argentina" Rafael Bellozupko Stremel

extinção ondulante e encontram-se pouco fraturados. O plagioclásio $\operatorname{An}_{(32-42)}$ compõe entre 15-20\% da matriz. O microclínio compõe entre 5-10\% da trama, exibe maclamento do tipo tartan (albitapericlina) irregular, ocasionalmente zonado e está parcialmente desestabilizado para mica branca. Os minerais acessórios ocorrem sob a forma de cristais euédricos a subédricos disseminados na associação quartzo + feldspatos, porém com discreta preferência pela associação com anfibólio e biotita. Dentre os acessórios, destaca-se elevada quantidade de titanita, cerca de $2 \%$ das amostras, exibindo tamanho entre 0,5-3 $\mathrm{mm}$ (Figura 2.7f).

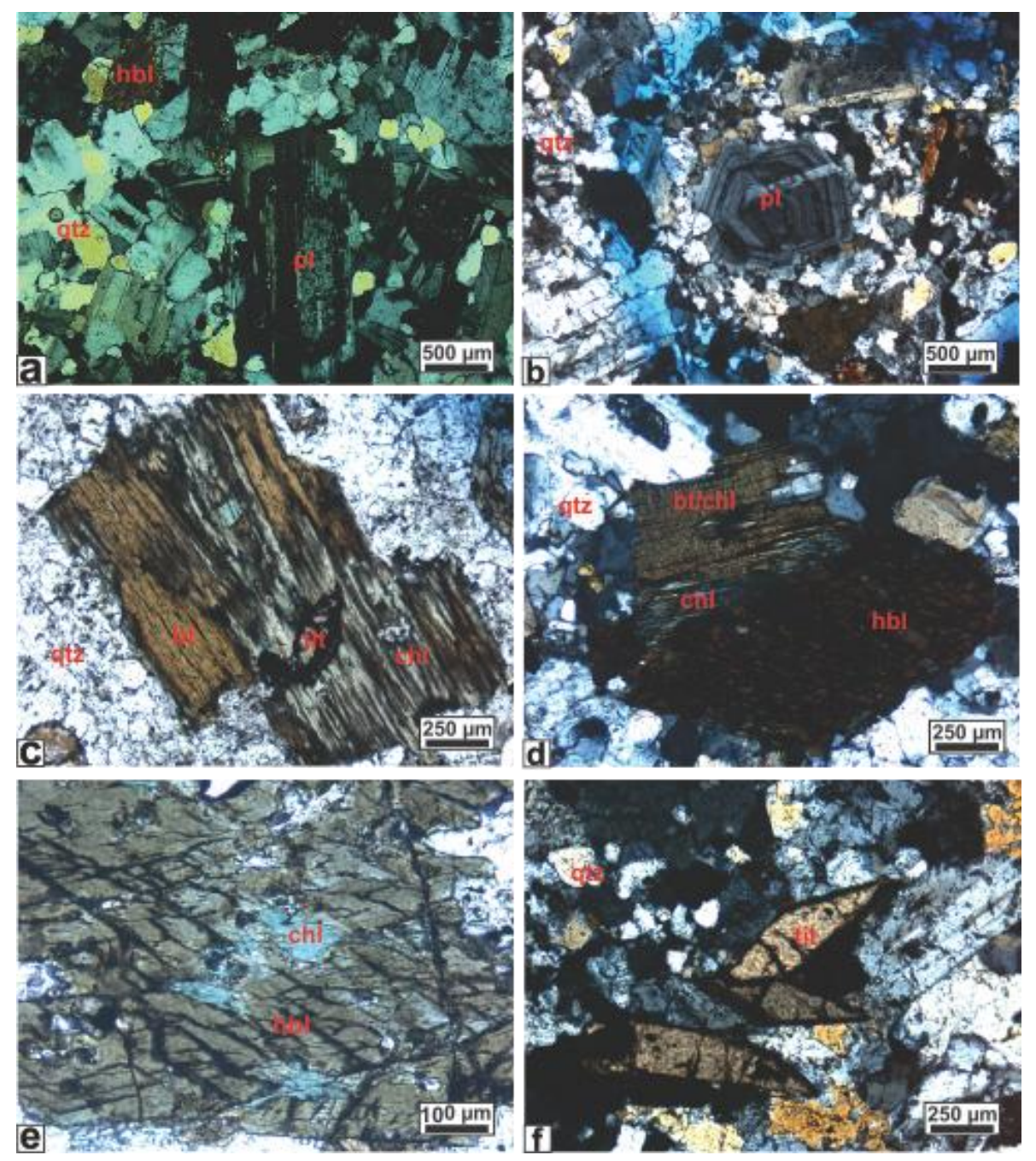

Figura 2.7 - Micrografias do quartzo monzodiorito, nicóis paralelos: N//, nicóis cruzados: NX. Qtz $=$ quartzo, Bt $=$ biotita, $\mathrm{Pl}=$ plagioclásio, $\mathrm{Chl}=$ clorita, Tit = titanita. a) $4 \mathrm{x}, \mathrm{N} / /$. Arranjo microtextural do stock de composição monzodiorito ressaltando o arranjo holocristalino inequigranular (MD 14). b) 4x, NX. Detalhe de fenocristal de plagioclásio com zonação composicional (PA 201). c) 10x, N//. Detalhe de fenocristal de biotita com parcial substituição para clorita e inclusão de grão de titanita (PA 201). d) 10x, NX. Detalhe de fenocristal da seção basal de um grão de hornblenda em contato com grão de biotita parcialmente substituído para clorita (PA 201). e) 20x, N//. Detalhe de cristal de hornblenda com parcial substituição para clorita ao longo dos planos de clivagem. (PA201). f) 10x, NX. Detalhe de grãos de titanita em sua seção losangular característica (PA 201). 
"O Sistema Magmático do Depósito de Cu-Mo Tipo Pórfiro Pancho Árias, Cordilheira Oriental, Argentina" Rafael Bellozupko Stremel

Diques e Sills Riodacíticos a Traqui-andesíticos - O quarto membro magmático identificado na área do depósito Pancho Árias é caracterizado por um sistema de diques e sills porfiríticos de composição riodacítica a traqui-andesítica, com orientação preferencial NW-SE e que atravessam tanto as rochas metassedimentares do embasamento quanto os demais membros magmáticos (Figuras 2.2d, 2.3). Esses diques e sills tem espessuras centimétricas a métricas e até centenas de metros de comprimento, exibem textura porfirítica, dada por fenocristais plagioclásio, quartzo e biotita, dispersos em matriz fina a afanítica de cor verde-escura a verde-acinzentada.

Petrograficamente, em geral, essas rochas exibem arranjo microtextural porfirítico, onde os fenocristais de plagioclásio, hornblenda, quartzo, biotita e feldspato potássico que se mostram dispersos em matriz microcristalina, composta por agregados de quartzo, plagioclásio e microclínio, além de titanita, pirita e zircão como acessórios (Figuras 2.8a, 2.8b).

Em relação aos fenocristais, o plagioclásio $\left(\mathrm{An}_{30-35}\right)$ é a fase mineral dominante, compondo 25-30\% das amostras, ocorre sob a forma de cristais subedrais a euedrais, possuem tamanho entre 1 e $5 \mathrm{~mm}$, apresentam zonamento composicional oscilatório, bordas desestabilizadas, marcadas por corrosão associada a interação cristal - líquido magmático. Preservam a geminação polissintética tipo albita (Figura 2.8b e 2.8i), porém, em sua maioria, estão parcial a totalmente substituídos por uma massa de mica branca (Figuras 2.8g, 2.8i). A hornblenda representa 5-10\% do volume modal, se apresenta sob a forma de cristais euedrais com tamanho entre 0,5 e $1 \mathrm{~mm}$, exibe pleocroísmo que varia do amarelo pálido ao verde escuro e apresenta substituição para clorita ao longo dos planos de clivagem (Figuras 2.8a, 2.8c, 2.8d). O quartzo compõe 3-6\% das amostras, ocorre sob a forma de cristais subedrais a subarredondados, com tamanho entre 0,5 e $2 \mathrm{~mm}$, exibem característica extinção ondulante e bordas corroídas com geração de cordões de subgrãos, além de golfos de corrosão e parcial reabsorção, produtos da interação com o líquido magmático. A clorita representa entre 2-5\% do volume modal, ocorre sob a forma de cristais subedrais a euedrais com tamanho entre 0,5 e $2 \mathrm{~mm}$, possui forte pleocroísmo entre verde-claro - amarelo-limão - verde, e, ocasionalmente, apresenta parcial substituição para carbonato e mica branca (Figuras 2.8e, 2.8f, 2.8j, 2.8k). A biotita compõe 1$2 \%$ do volume modal, ocorre sob a forma de cristais subedrais a euedrais, com tamanho em torno de 0,5 mm, apresentam pleocroísmo que varia do amarelo-pálido ao marrom-escuro e bordas marcadas por cordões de minerais opacos, provavelmente produtos da interação com o líquido magmático (Figura 2.8d).

Na matriz, a fase quartzo-feldspática microcristalina é dominante, cujos cristas são subédricos a anédricos e exibem contatos poligonizados. Os minerais acessórios ocorrem sob a forma de cristais 
"O Sistema Magmático do Depósito de Cu-Mo Tipo Pórfiro Pancho Árias, Cordilheira Oriental, Argentina" Rafael Bellozupko Stremel

subédricos disseminados na trama quartzo-feldspática, os quais destacam-se a titanita, zircão e pirita. Ocasionalmente, observa-se planos de microfraturas preenchidos por carbonatos.

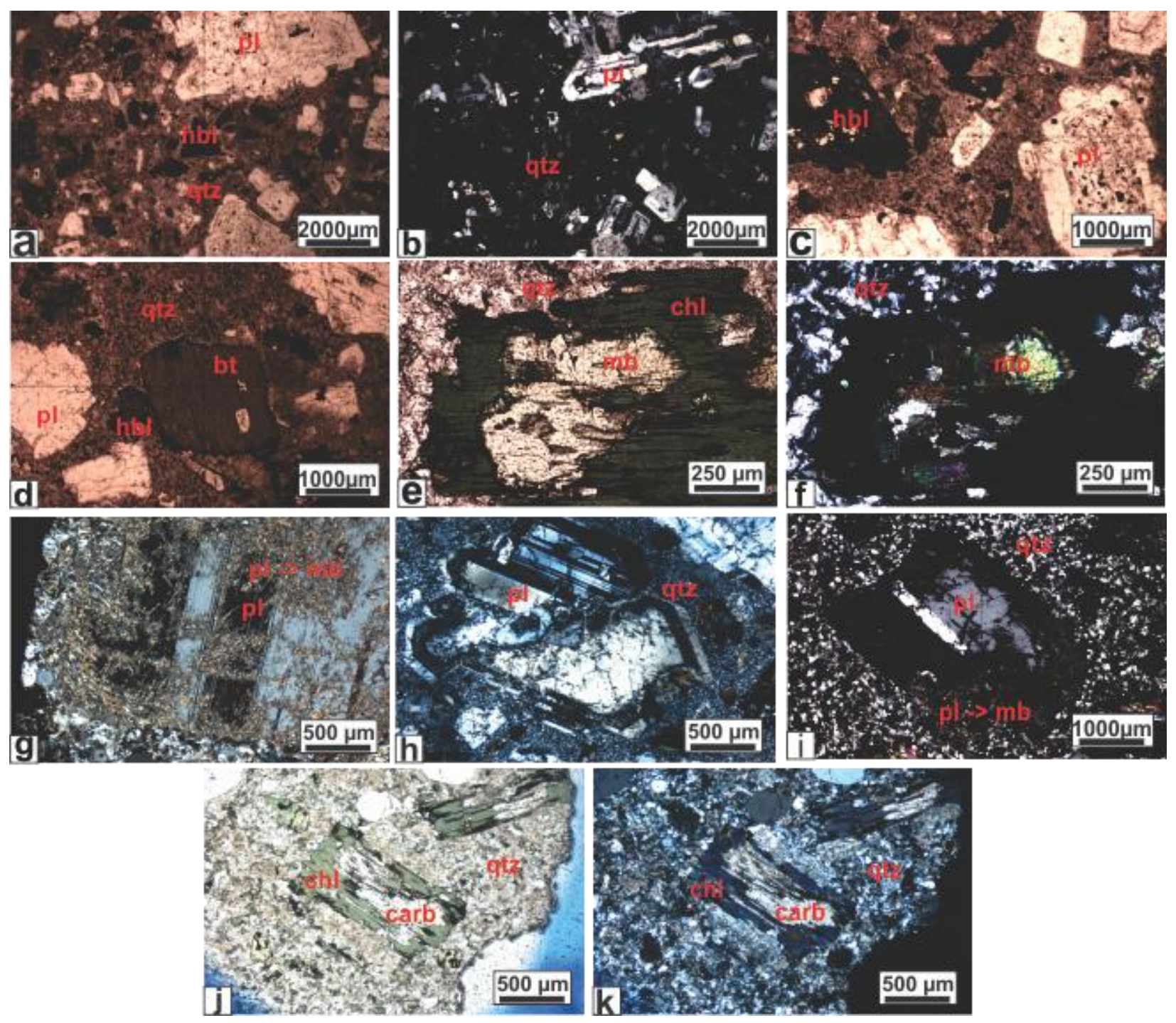

Figura 2.8 - Micrografias das rochas dos diques e sills, nicóis paralelos: N//, nicóis cruzados: NX. Qtz = quartzo, Bt = biotita, $\mathrm{Pl}=$ plagioclásio, $\mathrm{Chl}=$ clorita, $\mathrm{Mb}=$ mica branca e Carb = carbonato. a) 1,25x, N//. Arranjo microtextural dos fenocristais de plagioclásio, hornblenda, quartzo e biotita dispersos na matriz (DK12). b) 1,25x, NX. Arranjo microtextural das rochas dos diques, caracterizado por fenocristais de plagioclásio, hornblenda, quartzo e biotita. Destaca-se leve zonação composicional dos fenocristais de plagioclásio. (DK12). c) 2,5x, N//. Detalhe de fenocristais de plagioclásio zonado e hornblenda (DK12). d) 2,5x, N//. Detalhe de fenocristais de biotita (DK15). e) 10x, N//. Detalhe fenocristal fraturado de clorita com parcial desestabilização para mica branca (PA210). f) 10x, NX. Detalhe fenocristal fraturado de clorita com parcial desestabilização para mica branca (PA210). g) 4x, NX. Detalhe de fenocristal de plagioclásio com desestabilização de borda e nas fraturas para mica branca (PA220). h) 4x, NX. Detalhe de fenocristal de plagioclásio com zonação composicional (PA220). ) i) 2,5x, NX. Detalhe de fenocristal de plagioclásio com desestabilização de borda para mica branca (PA210). j) 4x, N//. Detalhe de fenocristal de clorita com parcial desestabilização para carbonato (PA220). k) 4x, N//. Detalhe de fenocristal de clorita com parcial desestabilização para carbonato (PA220). 
"O Sistema Magmático do Depósito de Cu-Mo Tipo Pórfiro Pancho Árias, Cordilheira Oriental, Argentina" Rafael Bellozupko Stremel

\subsubsection{Corpos de Brechas}

Os corpos de brechas ocorrem distribuídos por toda a área do prospecto Pancho Arias e estão intimamente ligados aos pórfiros andesíticos, e, mais localmente, ao stock monzodioritico. Possuem dimensões métricas a decamétricas e arranjo texturais e composicionais distintos, cujas características nos permitiram individualizar esses corpos de brecha em seis tipos, assim denominados conforme sua textura e distribuição na área do prospecto: 1) brechas polimíticas do setor centro-nordeste da área - Bn-01, Bn-02 e Bn-03; 2) brechas monomíticas a polimíticas do setor centro sudoeste - Bs-01, Bs-02 e Bs-03 (Figura 2.3). Em geral, esses corpos de brechas hospedam grande parte da mineralização em $\mathrm{Cu}$ identificada na área.

Bn-01- Ocorre no local denominado de Quebrada de Soquero associado aos pórfiros andesíticos (Figura 2.3). Apresenta a geometria cilíndrica de um corpo do tipo pipe de cor cinza escuro, está composto por fragmentos polimíticos angulosos a subangulosos, com tamanho que varia de 1 a $8 \mathrm{~cm}$, distribuídos num arranjo do tipo matriz suportado (Figura 2.9b). Os fragmentos são cristais (plagioclásio, quartzo, biotita), dos pórfiros andesíticos e encaixantes. A matriz é fina a afanítica, possui cor cinza escuro a preto e está fortemente silicificada e sulfetada, marcados respectivamente por intensa geração de veios e vênulas de quartzo, e disseminação de cristais de pirita e calcopirita com o tamanho que varia de 0,1 a $3 \mathrm{~mm}$.

Ao microscópio, a matriz exibe arranjo microcristalino inequigranular formado por agregados de quartzo-sericita-biotita contornando os fragmentos polimíticos (Figura 2.10a e 2.10b). Os fragmentos de cristais de plagioclásio e biotita exibem bordas corroídas e/ou contornadas por cordões de agregados microcristalinos de quartzo, se mostram total a moderadamente substituídos por sericita e clorita, respectivamente. O quartzo exibe contornos subarredondados e bordas corroídas, frequentemente marcadas por coronas de reação. Os fragmentos de rochas, por sua vez, também se mostram com contornos marcados por coronas de reação, frequentemente formadas por microagregados de quartzo-sericita-biotita. Os sulfetos (pirita e calcopirita) estão sob a forma de cristais subédricos disseminados e/ou formando agregados, distribuídos tanto na matriz como nos fragmentos de rochas.

Bn-02 - Localiza-se no setor setentrional do prospecto, às margens do rio Toro, associado aos pórfiros andesíticos. Exibe geometria elongada no sentido E-W e arranjo textural do tipo polimítico fragmento-suportado. É formada por fragmentos dos pórfiros andesíticos e da rocha metassedimentar encaixante, os quais são angulosos a sub-angulosos, com tamanho entre 1 e $10 \mathrm{~cm}$, cimentados por matriz fina a afanítica de cor cinza a cinza-escuro (Figura 2.9b). 
"O Sistema Magmático do Depósito de Cu-Mo Tipo Pórfiro Pancho Árias, Cordilheira Oriental, Argentina" Rafael Bellozupko Stremel

Em lâmina, a matriz exibe arranjo microcristalino inequigranular e é formada por agregado de quartzo-sericita. Os fragmentos de rocha apresentam coronas de reação formadas por microagregados de quartzo-sericita e sua mineralogia primária está parcial a totalmente substituída por agregados de sericita e biotita. Os sulfetos (pirita e calcopirita) estão sob a forma de cristais subédricos disseminados e/ou formando agregados distribuídos nos fragmentos de rochas e, localmente, associam-se a aglomerados de titanita (Figuras 2.10e, 2.10f).

Bn-03 - Ocorre na porção central da área, cincundando toda a fase magmática correspondente ao stock de composição quartzo-monzodiorítica. É caracterizado por um arranjo polimítico em matriz-suportada com fragmentos dos pórfiros andesíticos e quartzo monzodiorito, além de cristaloclastos de plagiocásio, quartzo e biotita (Figura 2.9d). Esses fragmentos são subangulosos a subarredondados, possuem tamanho entre 1 e $10 \mathrm{~cm}$ e são cimentados por uma matriz muito fina a afanítica de cor cinza-claro. Essa brecha é comumente afetada por processo de silificação, expressa através da formação de vênulas de quartzo, as quais estão associados a sulfuração (Figuras 2.9e e 2.9f).

O arranjo microtextural é ressaltado por matriz formada por um agregado microcristalino inequigranular de quartzo e biotita, que contorna os fragmentos polimíticos. Os cristaloclastos de plagioclásio apresentam-se com bordas corroídas e parcial a totalmente desestabilizados para sericita, por sua vez, os cristaloclastos de quartzo apresentam contornos arredondados, estão moderadamente fraturados e possuem bordas corroídas, frequentemente marcadas por coroas de reação, os cristais de biotita também possuem bordas corroídas, com formação de agregados de sericita-quartzo. Os fragmentos de rocha apresentam elevada variação de morfologia e de grau de alteração, com parcial a total substituição da mineralogia primária dos fragmentos, além de apresentarem coronas de reação marcado por formação de microagregados de quartzo e sericita (Figuras 2.10j, 2.10k). A sulfuração é marcada por cristais anedrais a subedrais de pirita com elevado grau de fraturamento.

Bs-01 - Localiza-se no extremo sul da área, possui geometria subcircular em planta e cor amarela a vermelha, provavelmente devido ao processo de oxidação supergênica. Este corpo é caracterizado por um arranjo monomítico em matriz suportada, ressaltado por fragmentos angulosos, com tamanho entre 1 e $5 \mathrm{~cm}$, da rocha metassedimentar encaixante, dispersos em matriz fina a afanítica, de coloração avermelhada (Figura 2.9g).

Em microscópio, a matriz exibe arranjo microcristalino inequigranular, formado por agregados de quartzo, sericita e oxi-hidróxidos de Fe que contornam os fragmentos das rochas metassedimentares encaixantes, cuja mineralogia é caracterizada por cristais anedrais de quartzo e 
"O Sistema Magmático do Depósito de Cu-Mo Tipo Pórfiro Pancho Árias, Cordilheira Oriental, Argentina" Rafael Bellozupko Stremel

sericita. Esses fragmentos exibem bordas corroídas marcadas por coronas de reação, frequentemente formadas por microagregados de quartzo e sericita (Figuras 2.10g, 2.10h).

Bs-02 - Localiza-se no setor austral do depósito, ao sul do local denominado como Quebrada de Soquero, e possui geometria com discreta elongação no sentido N-S. Este corpo é composto uma brecha com arranjo polimítico em matriz suportada, caracterizado por fragmentos sub-angulosos, com tamanho entre 1 e $8 \mathrm{~cm}$, imersos em matriz fina a afanítica de cor cinza-escuro a preto. Os fragmentos são compostos por cristais de quartzo, além de fragmentos de rocha compostos pelo pórfiro andesítico anfibólico e da rocha encaixante (Figura 2.9h).

Ao microscópio, a matriz exibe arranjo microcristalino inequigranular formado por agregados de magnetita-hematita-clorita-mica branca-quartzo contornando os fragmentos polimíticos. Destacase elevada quantidade de magnetita (aproximadamente $50 \%$ da matriz) e as feições radiais a concêntricas exibidas pelos cristais de clorita. Os fragmentos de cristais de quartzo exibem bordas corroídas e/ou contornadas por cordões de agregados microcristalinos de quartzo e sericita, além de se mostrarem fraturados. Os fragmentos de rocha estão com sua mineralogia primária parcial substituída, onde os fenocristais estão substituídos para mica branca, além de exibirem contornos marcados por coronas de reação, frequentemente formadas por microagregados de quartzo-sericitaclorita (Figuras 2.10i, 2.10j).

Bs-03- Também localizada na porção austral do depósito, no extremo sul da região denominada Quebrada de Soquero. Esse corpo de brecha possui geometria subarredondada com leve elongação na direção NE-SW. Possui coloração cinza escuro e é formada por um arranjo monomítico em matriz suportado, caracterizado por uma matriz fina a afanítica de coloração azul escura, onde estão dispersos fragmentos angulosos e fraturados, em textura do tipo jigsaw. O tamanho desses fragmentos variam entre 1 e $5 \mathrm{~cm}$, possuem coloração cinza-claro, e correspondem as rochas metassedimentares do embasamento (Figura 2.9i).

O arranjo microtextural é ressaltado por matriz formada por arranjo microcristalino inequigranular composta por agregados de turmalina com tamanho inferior a 0,2 $\mathrm{mm}$, clorita, óxihidróxidos de $\mathrm{Fe}$ e sericita, que contornam e preenchem as fraturas dos fragmentos monomíticos, ocasionalmente se formam aglomerados de turmalina em estruturas radiais. Os fragmentos apresentam contornos subarredondados e com reação de corrosão, frequentemente formadas por microagregados de turmalina-sericita (Figuras 2.10k, 2.101). 
"O Sistema Magmático do Depósito de Cu-Mo Tipo Pórfiro Pancho Árias, Cordilheira Oriental, Argentina" Rafael Bellozupko Stremel
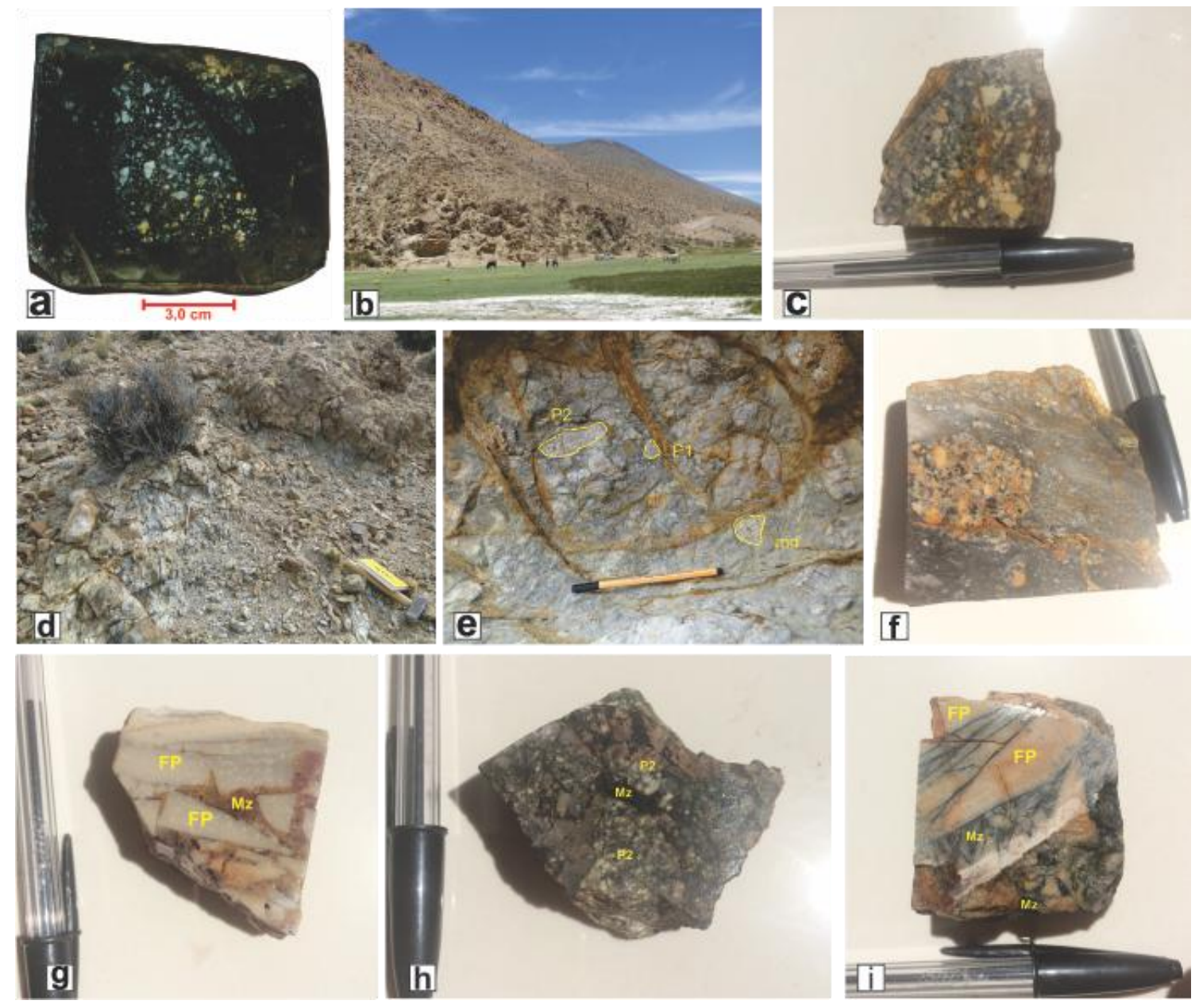

Figura 2.9- a) Amostra do corpo de brecha Bn-01, destaca-se fragmento do pórfiro andesítico biotítico e cristaloclastos de quartzo e plagioclásio, além de matriz de coloração cinza-escuro (Am. PA 217). b) Afloramento do corpo de brecha Bn-02, com elevado grau de oxidação que afeta o corpo. c) Detalhe de fragmento do pórfiro andesítico (Am. PA 237). d) Afloramento do corpo de Bn-03. e) Detalhe de fragmentos dos pórfiros andesíticos e stock quartzo monzodiorito. f) Amostra do corpo de brecha Bn-03, destacando fragmento do pórfiro andesítico anfibólico e matriz da rocha Am. PA 226). g) Amostra do corpo de brecha Bs-01, ressaltando os fragmentos da rocha encaixante (FP) e matriz da rocha (Mz, Am. PA 242). h) Amostra do corpo de brecha Bs-02. i) Amostra de corpo de breha Bs-03. 

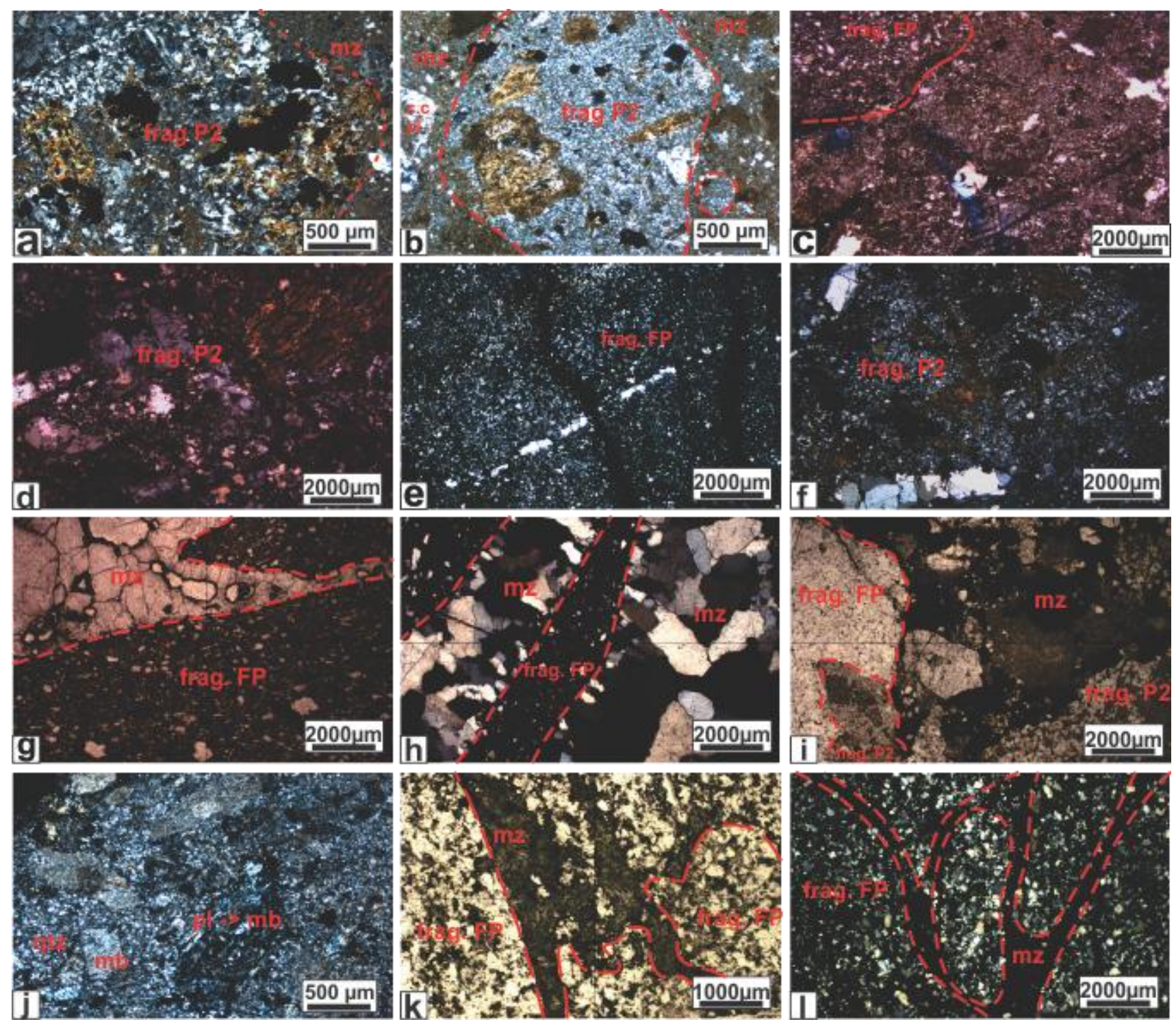

Figura 2.10- Nicóis paralelos: N//, nicóis cruzados: NX. a) 4x, NX. Textura do corpo Bn-01, ressaltando variados fragmentos e matriz composta por grãos de quartzo e sericita (PA 217D). b) 4x, NX. Detalhe fragmento de fase magmática porfirítica imerso em matriz composta por quartzo e sericita (PA 217). c) 1,25x, NX. Textura da brecha Bn02, mostrando contato entre diversos fragmentos (PA 235). d) 1,25x, NX. Detalhe de fragmento (PA 235). e) 1,25x, NX. Detalhe de fragmento da rocha encaixante no corpo de brecha Bn-03 (PA 226). f) 1,25x NX. Fragmento de algum membro magmático (PA 226). g) 1,25x, N//. Textura do corpo de brecha Bs-01, mostrando contato entre fragmento da rocha encaixante e da matriz composta por quartzo e mica branca (PA 242). h) 1,25x, N//. Textura do corpo de brecha Bs-01, mostrando contato entre fragmento da rocha encaixante e da matriz composta por quartzo e mica branca (PA 242). i) 1,25x, N//. Textura do corpo de brecha Bs-02, ressaltando fragmentos dispersos na matriz composta por óxidos (PA 241). j) 4x, NX. Detalhe de fragmento ressaltando fenocristal de plagioclásio com substituição para mica branca (PA 241). k) 2,5x, N//. Textura de corpo de brecha Bs-03, caracterizado por fragmentos arredondados e elongados da rocha encaixante e desenvolvimento de matriz composta por turmalina, quartzo e mica branca (PA 240). 1) 1,25x, NX. Tex tura de corpo Bs-03, caracterizado por fragmentos arredondados e elongados da rocha encaixante e desenvolvimento de matriz composta por turmalina, quartzo e mica branca (PA 240). 
"O Sistema Magmático do Depósito de Cu-Mo Tipo Pórfiro Pancho Árias, Cordilheira Oriental, Argentina"

Rafael Bellozupko Stremel

\subsection{Geoquímica}

Foram feitas análises multielementares em onze amostras de rocha total (pacote LF 200 da ACME). Das onze amostras analisadas, três correspondem ao pórfiro andesítico com biotita, quatro ao pórfiro andesítico com anfibólio, duas ao stock de composição quartzo monzodiorítica e duas as rochas dos diques e sills presentes na área. Neste último conjunto, uma amostra está localizada na porção externa do depósito, afetado por alteração hidrotermal do tipo propilítica e a outra está localizada na porção central e sem aparente alteração hidrotermal marcante (Tabela 2.1).

$\mathrm{O}$ pórfiro andesítico biotítico possui teores de $\mathrm{SiO}_{2}=67$ e $68 \%, \mathrm{Al}_{2} \mathrm{O}_{3}=14$ e $16 \%, \mathrm{FeOt}=3$ e $3,7 \%, \mathrm{MgO}=0,7$ e $1,4 \%, \mathrm{CaO}=0,6$ e 2,2\%, $\mathrm{Na}_{2} \mathrm{O}=1,7$ e 2,6\% e $\mathrm{K}_{2} \mathrm{O}=4,72$ e $6,84 \%$. Destacamse entre os elementos traço teores de $\mathrm{Rb}=143$ e $179 \mathrm{ppm}, \mathrm{Sr}=256$ e 483 ppm, $\mathrm{Nd}=15$ e $19 \mathrm{ppm}$, $\mathrm{Sm}=3,5$ e $5, \mathrm{Cu}=83$ e $5135 \mathrm{ppm}$ e $\mathrm{Mo}=121$ e $772 \mathrm{ppm}$, além de valores de perda ao fogo (P.F) entre 1,8 e 2,9 (Tabela 2.1).

O pórfiro andesítico com anfibólio possui teores de $\mathrm{SiO}_{2}=64,8$ e 68,2\%, $\mathrm{Al}_{2} \mathrm{O}_{3}=13,7$ e $17 \%$, $\mathrm{FeOt}=2,6$ e 4,5\%, $\mathrm{MgO}=0,7$ a $2 \%, \mathrm{CaO}=1$ e 2,3\%, $\mathrm{Na}_{2} \mathrm{O}=1,9$ e 2,6\% e $\mathrm{K}_{2} \mathrm{O}=4,5$ a $6,2 \%$. Destacam-se entre os elementos traço teores de $\mathrm{Rb}=133$ e $182 \mathrm{ppm}, \mathrm{Sr}=270$ e $485 \mathrm{ppm}, \mathrm{Nd}=14$ e 16 ppm, $\mathrm{Sm}=2,3$ a 3,3 ppm, $\mathrm{Cu}=43$ a 5345 ppm e $\mathrm{Mo}=45$ a 421 ppm, além de P.F = 2,2 e 3,3 (Tabela 2.1).

As amostras do stock quarto monzodiorítico apresentam teores de $\mathrm{SiO}_{2}=63,3 \%, \mathrm{Al}_{2} \mathrm{O}_{3}=13$ e $16,2 \%, \mathrm{FeOt}=4,8 \%, \mathrm{MgO}=1,75 \%, \mathrm{CaO}=5,2 \%, \mathrm{Na}_{2} \mathrm{O}=3,4 \%$ e $\mathrm{K}_{2} \mathrm{O}=3,4 \%$. Destacam-se entre os elementos traço teores de $\mathrm{Rb}=119$ e 128 ppm, $\mathrm{Sr}=531$ e 570 ppm, $\mathrm{Nd}=17$ e 19 ppm, $\mathrm{Sm}=3,2$ e 3,7 ppm e $\mathrm{Cu}=193$ e 204, além de P.F = 1 e 1,1 (Tabela 2.1).

As rochas dos diques e sills possuem teores de $\mathrm{SiO}_{2}=73,5 \%, \mathrm{Al}_{2} \mathrm{O}_{3}=13,5 \%$, $\mathrm{FeOt}=1,3 \mathrm{e}$ $2 \%, \mathrm{Na}_{2} \mathrm{O}=2,4$ e $2,7 \%, \mathrm{~K}_{2} \mathrm{O}=4,8$ a 5,4\%. Destacam-se entre os elementos traço teores de $\mathrm{Rb}=164$ e 211 ppm, $\mathrm{Sr}=41$ e $102 \mathrm{ppm}, \mathrm{Nd}=13$ e 33 ppm, $\mathrm{Sm}=2,5$ e 6,7 ppm e $\mathrm{Cu}=12$ e 139 ppm, além de P.F $=1,5$ e 2,2 (Tabela 2.1). 
"O Sistema Magmático do Depósito de Cu-Mo Tipo Pórfiro Pancho Árias, Cordilheira Oriental, Argentina" Rafael Bellozupko Stremel

Tabela 2.1 - Composição química das quatro fases magmáticas do depósito Pancho Árias.

\begin{tabular}{|c|c|c|c|c|c|c|c|c|c|c|c|}
\hline $\begin{array}{l}\text { Litotipo } \\
\text { Amostra }\end{array}$ & $\begin{array}{c}\text { PAB } \\
\text { PA-101 }\end{array}$ & $\begin{array}{c}\text { PAB } \\
\text { PA-101B }\end{array}$ & $\begin{array}{c}\text { PAB } \\
\text { PA-105 }\end{array}$ & $\begin{array}{c}\text { PAA } \\
\text { PA-MD20 }\end{array}$ & $\begin{array}{c}\text { PAA } \\
\text { PA-AND01 }\end{array}$ & $\begin{array}{c}\text { PAA } \\
\text { PA-AND17 }\end{array}$ & $\begin{array}{c}\text { PAA } \\
\text { PA-XX }\end{array}$ & $\begin{array}{c}\text { Qz-md } \\
\text { PA-106A }\end{array}$ & $\begin{array}{l}\text { Qz-md } \\
\text { PA-106 }\end{array}$ & $\begin{array}{c}\text { Dique } \\
\text { PA-107 }\end{array}$ & $\begin{array}{r}\text { Dique } \\
\text { PA-223 }\end{array}$ \\
\hline $\mathrm{SiO}_{2}(\%)$ & 67,36 & 67,29 & 68,25 & 68,21 & 64,84 & 66,91 & 66,31 & 63,21 & 63,48 & 74,07 & 73,27 \\
\hline $\mathrm{TiO}_{2}$ & 0,56 & 0,56 & 0,37 & 0,53 & 0,51 & 0,49 & 0,40 & 0,58 & 0,57 & 0,24 & 0,31 \\
\hline $\mathrm{Al}_{2} \mathrm{O}_{3}$ & 15,84 & 15,94 & 13,93 & 13,66 & 16,09 & 16,07 & 14,68 & 16,2 & 13,00 & 13,61 & 13,24 \\
\hline $\mathrm{Fe}_{2} \mathrm{O}_{3}$ & 3,00 & 2,99 & 3,68 & 3,82 & 3,83 & 2,57 & 4,51 & 4,86 & 4,80 & 2,03 & 1,31 \\
\hline $\mathrm{MnO}$ & 0,02 & 0,02 & 0,02 & 0,04 & 0,03 & 0,01 & 0,02 & 0,11 & 0,11 & 0,03 & 0,01 \\
\hline $\mathrm{MgO}$ & 1,39 & 1,36 & 0,70 & 1,46 & 1,96 & 1,01 & 0,74 & 1,75 & 1,76 & 0,58 & 0,55 \\
\hline $\mathrm{CaO}$ & 2,16 & 2,15 & 0,62 & 1,53 & 2,32 & 2,2 & 0,97 & 5,21 & 5,13 & 0,18 & 1 \\
\hline $\mathrm{Na}_{2} \mathrm{O}$ & 2,61 & 2,63 & 1,73 & 1,87 & 2,65 & 2,59 & 1,99 & 3,39 & 3,44 & 2,67 & 2,37 \\
\hline $\mathrm{K} 2 \mathrm{O}$ & 4,80 & 4,72 & 6,84 & 6,2 & 5,2 & 4,54 & 6,71 & 3,1 & 3,12 & 4,84 & 5,42 \\
\hline $\mathrm{P}_{2} \mathrm{O}_{5}$ & 0,13 & 0,14 & 0,07 & 0,16 & 0,15 & 0,07 & 0,06 & 0,21 & 0,20 & 0,10 & 0,07 \\
\hline P.F. & 1,80 & 1,90 & 2,90 & 2,3 & 2,2 & 3,3 & 2,70 & 1,1 & 1,00 & 1,50 & 2,2 \\
\hline TOTAL & 99,72 & 99,72 & 99,08 & 99,75 & 99,75 & 99,75 & 99,11 & 99,73 & 99,73 & 99,84 & 99,76 \\
\hline $\mathrm{Be}(\mathrm{ppm})$ & 1 & 3 & 2 & $<1$ & 2 & 3 & 2 & 1 & $<1$ & $<1$ & $<1$ \\
\hline $\mathrm{Rb}$ & 148,8 & 143,3 & 178,8 & 150,1 & 177,8 & 132,5 & 182,3 & 119 & 127,7 & 164,4 & 211,2 \\
\hline Cs & 1,1 & 1,1 & 1,4 & 1 & 2,2 & 1,3 & 1,5 & 1,4 & 1,3 & 4,1 & 3,2 \\
\hline $\mathrm{Ba}$ & 588 & 571 & 609 & 641 & 545 & 554 & 555 & 550 & 522 & 435 & 391 \\
\hline $\mathrm{Sr}$ & 483,4 & 469,0 & 256,2 & 382,8 & 485,4 & 457,5 & 270,2 & 530,5 & 570,0 & 41,3 & 101,8 \\
\hline $\mathrm{Ga}$ & 16,8 & 15,9 & 12,2 & 14,7 & 16,5 & 13,5 & 13,2 & 16,5 & 15,1 & 15,1 & 11,3 \\
\hline V & 85 & 83 & 52 & 87 & 87 & 78 & 58 & 102 & 93 & 13 & 32 \\
\hline $\mathrm{Ta}$ & 1,5 & 1,4 & 1,4 & 1,7 & 1,8 & 1,9 & 1,6 & 1,9 & 1,9 & 1,3 & 1,4 \\
\hline $\mathrm{Nb}$ & 21,0 & 20,6 & 22,5 & 26,3 & 24,7 & 26,5 & 23,7 & 22,4 & 23,0 & 14,2 & 13,2 \\
\hline Th & 7,0 & 6,5 & 6,6 & 8,4 & 7,5 & 6,6 & 6,6 & 6,9 & 7,9 & 15,3 & 9,9 \\
\hline $\mathrm{U}$ & 3,0 & 2,8 & 2,2 & 2,3 & 3,4 & 3 & 3,3 & 2,8 & 2,7 & 4,0 & 4,9 \\
\hline $\mathrm{Zr}$ & 133,8 & 129,9 & 121,5 & 117,6 & 147,7 & 155,1 & 137,9 & 134,9 & 162,2 & 166,0 & 88,6 \\
\hline $\mathrm{Hf}$ & 3,5 & 3,3 & 3,1 & 3,1 & 3,7 & 4 & 3,3 & 3,6 & 3,8 & 4,9 & 2,3 \\
\hline $\mathrm{Y}$ & 31,7 & 27,9 & 29,2 & 10,5 & 22,3 & 10,4 & 21,7 & 16,4 & 16,3 & 31,0 & 16,1 \\
\hline $\mathrm{Sc}$ & 8 & 8 & 5 & 7 & 6 & 5 & 5 & 8 & 8 & 6 & 6 \\
\hline $\mathrm{Ni}$ & 9,9 & 9,8 & 6,5 & 6,4 & 5,9 & 3,9 & 3,5 & 2,9 & 2,8 & 2,3 & 3,5 \\
\hline $\mathrm{Cu}$ & 86,6 & 83,1 & 5134,5 & 65,4 & 42,9 & 84,8 & 5344,5 & 193,2 & 204,3 & 11,9 & 139,4 \\
\hline $\mathrm{Zn}$ & 37 & 37 & 20 & 34 & 26 & 8 & 19 & 13 & 16 & 102 & 6 \\
\hline $\mathrm{Pb}$ & 0,6 & 0,6 & 3,0 & 0,6 & 0,4 & 0,7 & 2,4 & 0,9 & 1,2 & 7,9 & 0,8 \\
\hline Mo & 120,5 & 121,3 & 772,2 & 44,6 & 81 & 66,5 & 421,3 & 0,2 & 0,3 & 0,5 & 4,5 \\
\hline $\mathrm{Au}(\mathrm{ppb})$ & 14,2 & 12,8 & 23,0 & 2,6 & 1 & 7,1 & 27,2 & $<0.5$ & 0,9 & $<0.5$ & $<0.5$ \\
\hline $\mathrm{La}(\mathrm{ppm})$ & 28,3 & 29,1 & 27,0 & 16,5 & 20,1 & 23 & 25,7 & 26,6 & 29,0 & 36,4 & 19 \\
\hline $\mathrm{Ce}$ & 48,7 & 47,1 & 44,4 & 30,7 & 35,7 & 39,4 & 44,5 & 46,9 & 45,8 & 77,8 & 34,5 \\
\hline $\operatorname{Pr}$ & 5,11 & 4,86 & 4,26 & 3,52 & 3,82 & 4,08 & 4,24 & 5,02 & 4,91 & 8,77 & 3,53 \\
\hline $\mathrm{Nd}$ & 19,4 & 18,5 & 15,3 & 13,5 & 14,1 & 14 & 16,2 & 18,8 & 17,3 & 33,4 & 13 \\
\hline $\mathrm{Sm}$ & 4,86 & 4,81 & 3,47 & 2,31 & 2,99 & 2,32 & 3,27 & 3,68 & 3,23 & 6,66 & 2,52 \\
\hline $\mathrm{Eu}$ & 1,60 & 1,53 & 1,12 & 0,74 & 0,89 & 0,75 & 1,00 & 0,91 & 0,99 & 0,96 & 0,66 \\
\hline Gd & 7,22 & 6,66 & 4,80 & 2,26 & 3,67 & 2,12 & 3,61 & 3,32 & 3,20 & 6,25 & 2,67 \\
\hline $\mathrm{Tb}$ & 1,25 & 1,24 & 0,83 & 0,33 & 0,63 & 0,31 & 0,61 & 0,5 & 0,48 & 0,98 & 0,43 \\
\hline Dy & 7,29 & 7,15 & 4,73 & 2,04 & 3,58 & 1,78 & 3,47 & 3 & 2,70 & 5,56 & 2,59 \\
\hline Ho & 1,49 & 1,47 & 0,94 & 0,38 & 0,85 & 0,4 & 0,74 & 0,56 & 0,60 & 1,18 & 0,55 \\
\hline $\mathrm{Er}$ & 4,02 & 3,85 & 2,89 & 1,21 & 2,49 & 1,31 & 2,26 & 1,68 & 1,64 & 3,26 & 1,92 \\
\hline $\mathrm{Tm}$ & 0,55 & 0,52 & 0,42 & 0,16 & 0,35 & 0,16 & 0,32 & 0,26 & 0,26 & 0,47 & 0,31 \\
\hline $\mathrm{Yb}$ & 3,13 & 3,34 & 2,75 & 1,26 & 2,67 & 1,39 & 2,00 & 1,91 & 1,65 & 2,91 & 2,06 \\
\hline $\mathrm{Lu}$ & 0,44 & 0,40 & 0,45 & 0,19 & 0,37 & 0,22 & 0,32 & 0,29 & 0,26 & 0,46 & 0,34 \\
\hline
\end{tabular}


"O Sistema Magmático do Depósito de Cu-Mo Tipo Pórfiro Pancho Árias, Cordilheira Oriental, Argentina" Rafael Bellozupko Stremel

Tabela 2.1 - Continuação

\begin{tabular}{|c|c|c|c|c|c|c|c|c|c|c|c|}
\hline $\begin{array}{l}\text { Litotipo } \\
\text { Amostra }\end{array}$ & $\begin{array}{c}\text { PAB } \\
\text { PA-101 }\end{array}$ & $\begin{array}{c}\text { PAB } \\
\text { PA101B }\end{array}$ & $\begin{array}{c}\text { PAB } \\
\text { PA105 }\end{array}$ & $\begin{array}{c}\text { PAA } \\
\text { PAmd20 }\end{array}$ & $\begin{array}{c}\text { PAA } \\
\text { PAand01 }\end{array}$ & $\begin{array}{c}\text { PAA } \\
\text { PAand17 }\end{array}$ & $\begin{array}{c}\text { PAA } \\
\text { PAXX }\end{array}$ & $\begin{array}{l}\text { Qz-md } \\
\text { PA106a }\end{array}$ & $\begin{array}{r}\text { Qz-md } \\
\text { PA-106 }\end{array}$ & $\begin{array}{l}\text { Dique } \\
\text { PA107 }\end{array}$ & $\begin{array}{r}\text { Dique } \\
\text { PA223 } \\
\end{array}$ \\
\hline $\mathrm{Eu} / \mathrm{Eu}^{*}$ & 0,83 & 0,83 & 0,84 & 0,99 & 0,82 & 1,03 & 0,89 & 0,20 & 0,30 & 0,45 & 0,78 \\
\hline $\mathrm{LaN} / \mathrm{YbN}$ & 6,10 & 5,87 & 6,62 & 8,83 & 5,08 & 11,16 & 8,66 & 9,39 & 11,85 & 8,43 & 6,22 \\
\hline $\mathrm{LaN} / \mathrm{SmN}$ & 3,66 & 3,81 & 4,89 & 4,49 & 4,23 & 6,24 & 4,94 & 4,55 & 5,65 & 3,44 & 4,74 \\
\hline $\mathrm{CeN} / \mathrm{YbN}$ & 4,02 & 3,65 & 4,18 & 6,30 & 3,46 & 7,33 & 5,76 & 6,35 & 7,18 & 6,92 & 4,33 \\
\hline $\mathrm{CeN} / \mathrm{SmN}$ & 2,42 & 2,36 & 3,09 & 3,21 & 2,88 & 4,10 & 3,28 & 3,08 & 3,42 & 2,82 & 3,30 \\
\hline $\mathrm{EuN} / \mathrm{YbN}$ & 1,45 & 1,30 & 1,16 & 1,67 & 0,95 & 1,53 & 1,42 & 1,35 & 1,71 & 0,94 & 0,91 \\
\hline Sum_REE & 133,36 & 130,53 & 113,36 & 75,10 & 92,21 & 91,24 & 108,24 & 113,43 & 112,02 & 185,1 & 84,08 \\
\hline $\mathrm{Na}_{2} \mathrm{O}+\mathrm{K}_{2} \mathrm{O}-\mathrm{CaO}$ & 5,25 & 5,20 & 7,95 & 6,54 & 5,53 & 4,93 & 7,73 & 1,28 & 1,43 & 7,33 & 6,79 \\
\hline $\mathrm{Feot} /(\mathrm{FeOt}+\mathrm{MgO})$ & 0,68 & 0,69 & 0,84 & 0,72 & 0,66 & 0,72 & 0,86 & 0,74 & 0,73 & 0,78 & 0,70 \\
\hline $\mathrm{Y}+\mathrm{Nb}$ & 52,70 & 48,50 & 51,70 & 36,80 & 47,00 & 36,90 & 45,40 & 38,80 & 39,30 & 45,20 & 29,30 \\
\hline $\mathrm{Ta}+\mathrm{Yb}$ & 4,63 & 4,74 & 4,15 & 2,96 & 4,47 & 3,29 & 3,60 & 3,81 & 3,55 & 4,21 & 3,46 \\
\hline A/NK & 1,67 & 1,69 & 1,36 & 1,40 & 1,61 & 1,75 & 1,39 & 1,81 & 1,79 & 1,41 & 1,36 \\
\hline $\mathrm{A} / \mathrm{CNK}$ & 1,18 & 1,19 & 1,22 & 1,09 & 1,13 & 1,22 & 1,19 & 0,88 & 0,88 & 1,37 & 1,14 \\
\hline $\mathrm{K}_{2} \mathrm{O} / \mathrm{Na}_{2} \mathrm{O}$ & 1,84 & 1,79 & 3,95 & 3,32 & 1,96 & 1,75 & 3,37 & 0,91 & 0,91 & 1,81 & 2,29 \\
\hline $\mathrm{R} 1$ & 2344,9 & 2352,0 & 2227,2 & 2316,7 & 2049,2 & 2395,6 & 2013,9 & 2140,1 & 2137,4 & 2794 & 2728,7 \\
\hline $\mathrm{R} 2$ & 610,8 & 610,2 & 374,3 & 504,1 & 661,1 & 600,7 & 428,5 & 962,0 & 891,2 & 315 & 393,9 \\
\hline $\mathrm{La} / \mathrm{Ta}$ & 18,87 & 20,79 & 19,29 & 9,71 & 11,17 & 12,11 & 16,06 & 14,00 & 15,26 & 28,00 & 13,57 \\
\hline $\mathrm{La} / \mathrm{Yb}$ & 9,04 & 8,71 & 9,82 & 13,10 & 7,53 & 16,55 & 12,85 & 13,93 & 17,58 & 12,51 & 9,22 \\
\hline $\mathrm{Ba} / \mathrm{Nb}$ & 28,00 & 27,72 & 27,07 & 24,37 & 22,06 & 20,91 & 23,42 & 24,55 & 22,70 & 30,63 & 29,62 \\
\hline Mg\# & 47,86 & 47,40 & 27,37 & 43,09 & 50,35 & 43,78 & 24,53 & 41,64 & 42,08 & 36,15 & 45,41 \\
\hline
\end{tabular}

Os membros magmáticos sub-vulcânicos possuem assinatura geoquímica de elementos menos móveis $(\mathrm{Zr}, \mathrm{Ti}, \mathrm{Nb}$ e $\mathrm{Y})$ que variam entre os campos de riodacito a traquiandesito (Figura 2.11). 
"O Sistema Magmático do Depósito de Cu-Mo Tipo Pórfiro Pancho Árias, Cordilheira Oriental, Argentina" Rafael Bellozupko Stremel

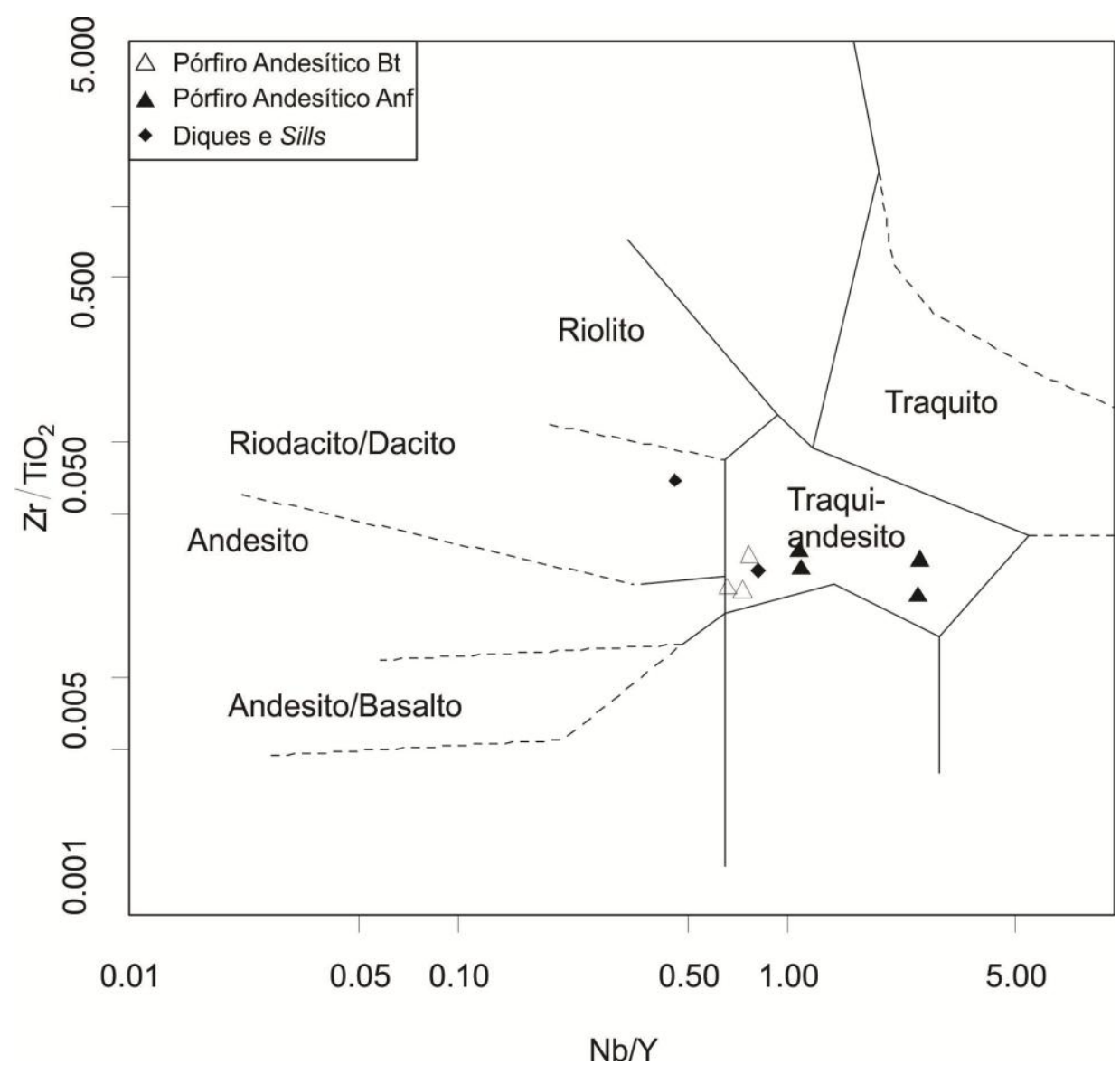

Figura 2.11 Diagrama de classificação de rochas vulcânicas $\left(\mathrm{Zr} / \mathrm{TiO}_{2} \mathrm{xNb} / \mathrm{Y}\right)$, proposto por Winchester \& Floyd, 1977 .

Para análise de características em relação a alcalinidade e aluminosidade das fases magmáticas aqui estudadas, foram aplicados os diagramas propostos por Frost et al. (2001) e Shand (1943), indicados nas figuras 2.12 a,b,c e 2.13. De acordo com esses diagramas, as rochas dos pórfiros andesíticos apresentam comportamento álcali-cálcico a alcalino e são peraluminosas. As rochas do stock quartzo monzodiorítico apresentam comportamento essencialmente cálcio-alcalino e metaluminoso, enquanto as rochas dos diques e sills apresentam comportamento intermediário entre o campo cálcio-alcalino e álcali-cálcico e são peraluminosas. 
"O Sistema Magmático do Depósito de Cu-Mo Tipo Pórfiro Pancho Árias, Cordilheira Oriental, Argentina" Rafael Bellozupko Stremel
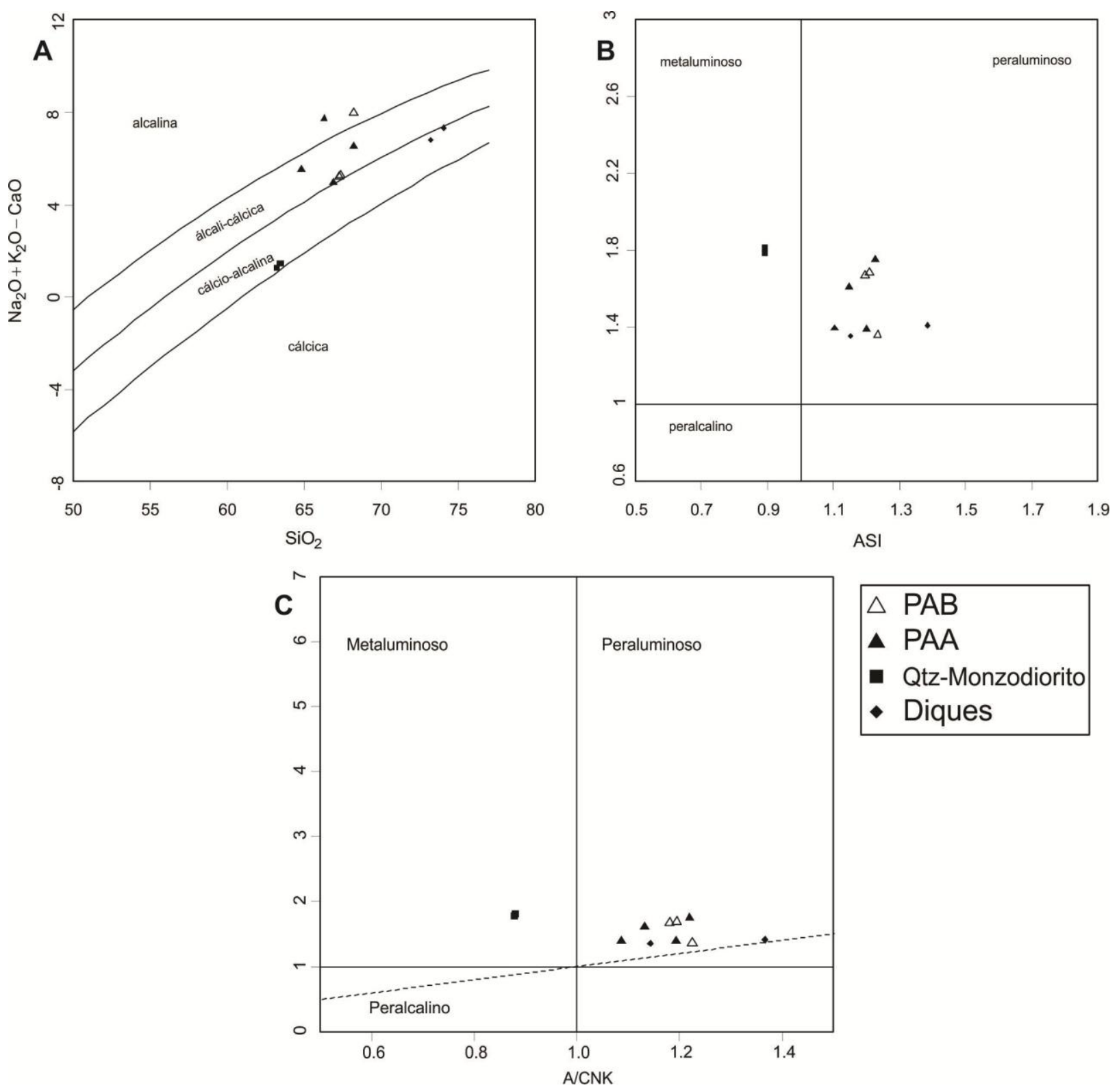

Figura 2.12- a) Diagrama $\mathrm{Na}_{2} \mathrm{O}+\mathrm{K}_{2} \mathrm{O}-\mathrm{CaO} \times \mathrm{SiO}_{2}$ de classificação de alcalinidade para rochas graníticas proposto por Frost et al. (2001). b) Diagrama A/NK x ASI de classificação de aluminosidade para rochas graníticas proposto por Frost et al. (2001). c) Diagrama A/NK x A/CNK de classificação de aluminosidade para rochas graníticas proposto por Shand (1943).

Quanto a ambiência tectônica, no diagrama $\left(\mathrm{FeOt} /[\mathrm{FeOt}+\mathrm{MgO}] \times \mathrm{SiO}_{2}\right)$ esses membros magmáticos distribuem-se preferencialmente no campo de granitos de cordilheira, enquanto apenas duas amostras, uma de cada pórfiro andesítico, estão no campo de granitos tipo A, porém próximas ao limite com o campo de granito de cordilheira e provavelmente são resultado do processo de alteração hidrotermal (Figura 2.13). 
"O Sistema Magmático do Depósito de Cu-Mo Tipo Pórfiro Pancho Árias, Cordilheira Oriental, Argentina" Rafael Bellozupko Stremel

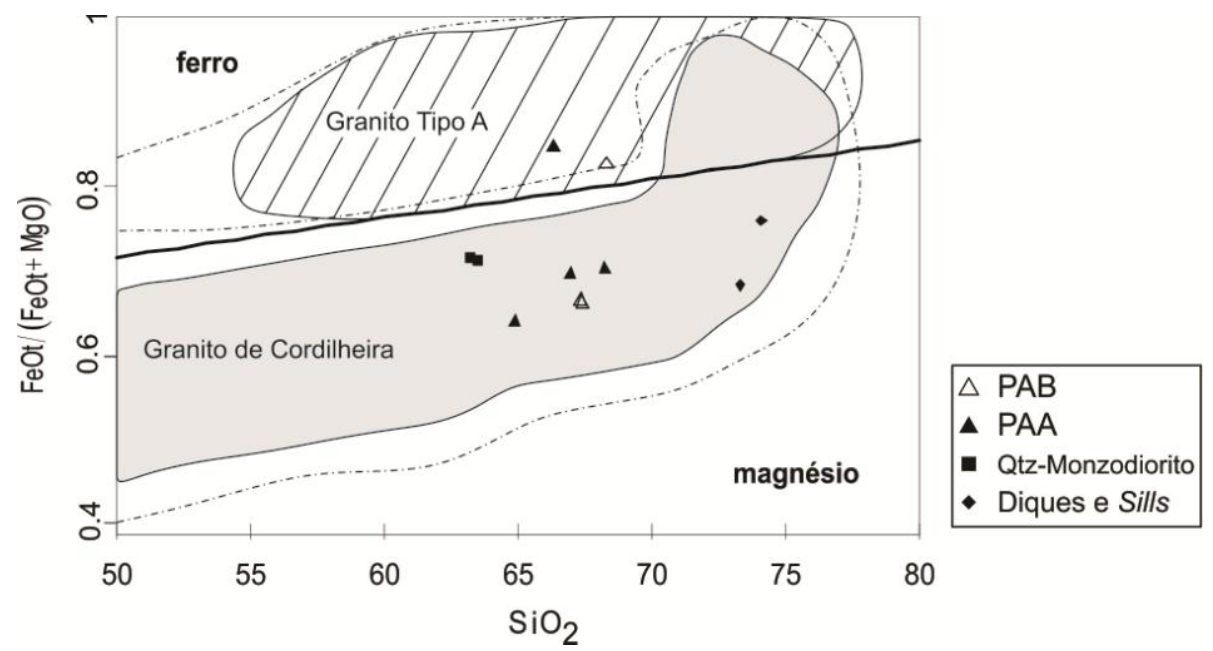

Figura 2.13- Diagrama $\mathrm{FeOt} /(\mathrm{FeOt}+\mathrm{MgO})$ x $\mathrm{SiO}_{2}$ para classificação de granitos, proposto por Frost et al. (2001).

Adicionalmente, aplicando os diagramas de classificação tectônica proposto por Pearce et al. (1984), as rochas analisadas distribuem-se entre os campos dos granitos sin-colisionais e de arco vulcânico, próximo ao limite do campo com os granitos intraplaca (Figura 2.14).
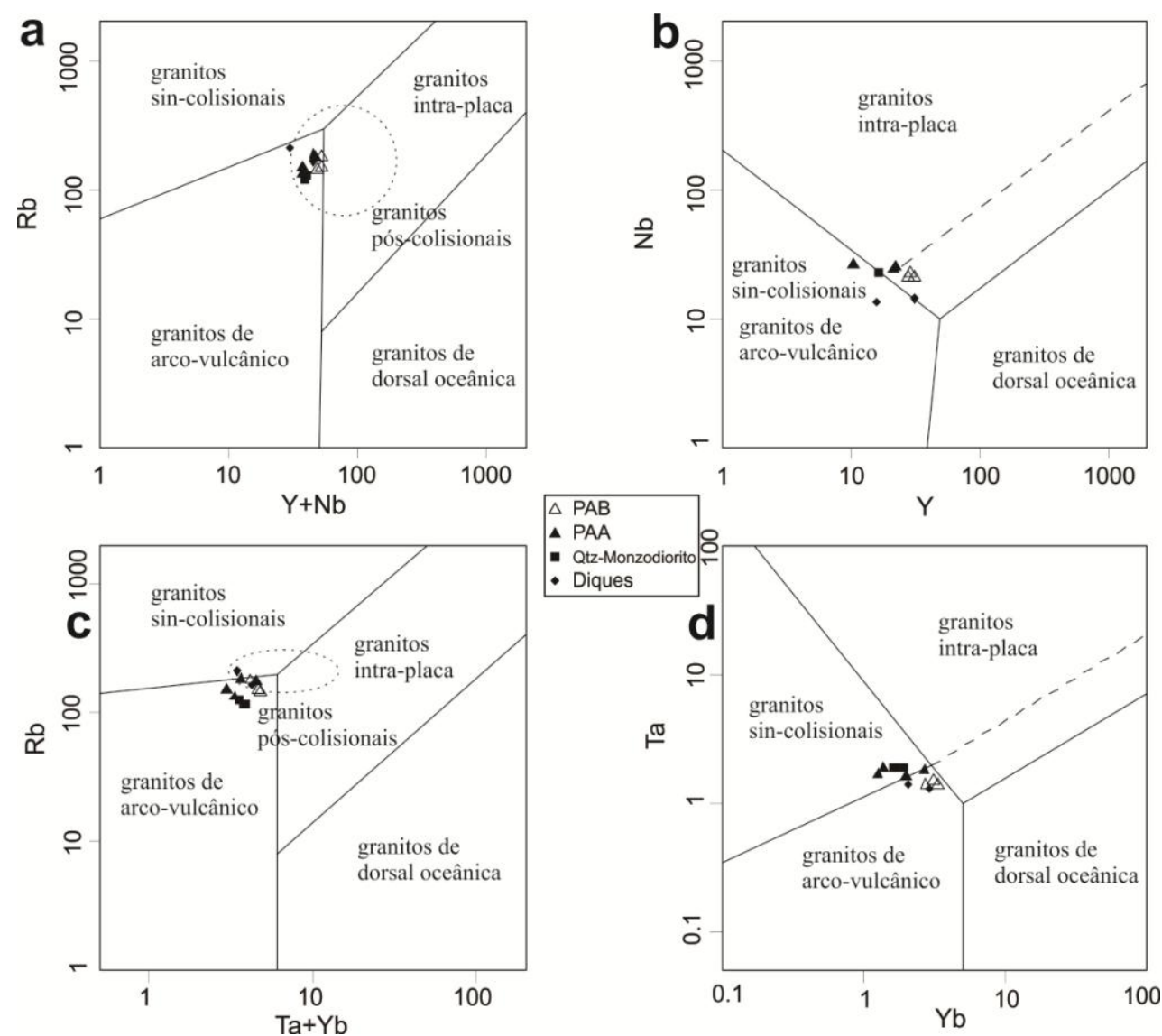

Figura 2.14- a) Diagrama de classificação geotectônica para rochas graníticas $(\mathrm{Rb} x \mathrm{Y})+\mathrm{Nb}$. b) Diagrama de classificação geotectônica para rochas graníticas $(\mathrm{Nb} \times \mathrm{Y})$. c) Diagrama de classificação geotectônica para rochas graníticas $\mathrm{Rb} \times \mathrm{Ta}+\mathrm{Yb}$. d) Diagrama de classificação geotectônica para rochas graníticas Ta x Yb. Todos propostos por Pearce et al. (1984). 
"O Sistema Magmático do Depósito de Cu-Mo Tipo Pórfiro Pancho Árias, Cordilheira Oriental, Argentina" Rafael Bellozupko Stremel

Em uma análise comparativa com dados oriundos de investigações geoquímicas realizadas na Cordilheira Oriental da Argentina, as rochas identificadas no prospecto Pancho Árias distribuem-se no campo de evolução do sistema magmático miocênico desenvolvido ao longo do lineamento Calama-Olacapato-El Toro (Figura 2.15).

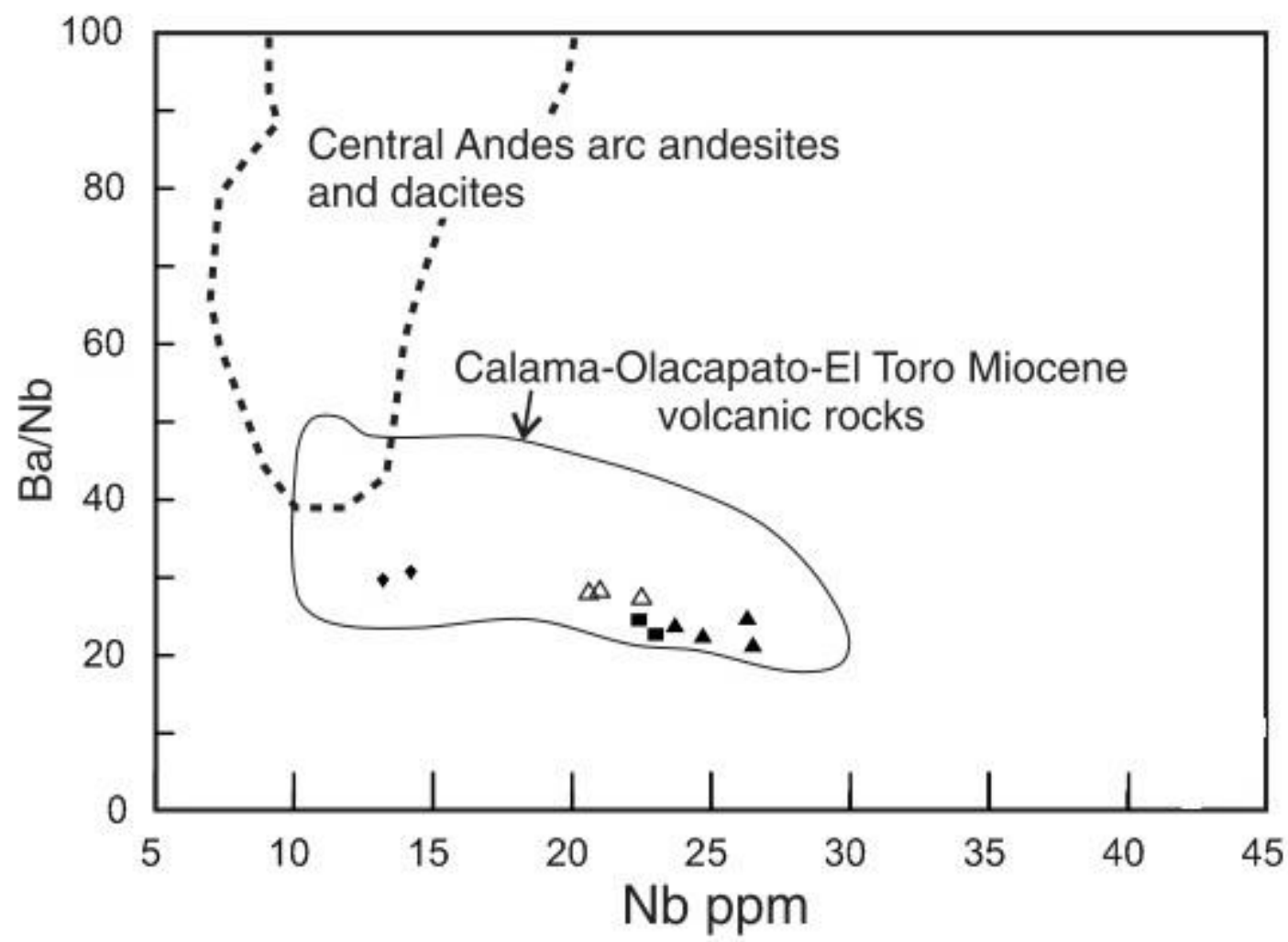

Figura 2.15 - Diagrama $\mathrm{Ba} / \mathrm{Nb}$ x Nb de elementos traço para as rochas do prospecto Pancho Árias. As rochas vulcânicas formadas ao longo da zona de falhas COT (Puntas Negras, Deruelle (1994); Rincon, Quevar, Goddard et al. (1999)); Tul Tul-Del Medio-Pocitos, Matteini et al., 2002a; Negra Muerta, Petrinovic et al. (2005)), e as rochas vulcânicas da zona de arco vulcânica central (Thorpe et al. (1984); Trumbull et al. (1999) são apresentados para comparação. CA calcialcalino. Os símbolos são os mesmos das demais figuras da geoquímica

Em relação aos elementos terras raras (ETR) as rochas do pórfiro andesítico com biotita estão enriquecidas cerca de 80 vezes no conteúdo de La-Ce em relação ao condrito e exibe leve a moderado fracionamento dos ETR leves em relação aos ETR pesados ([La/Yb $]_{\mathrm{N}}=5,9$ a 6,6), além de discreta anomalia no elemento $\mathrm{Eu}\left(\mathrm{Eu} / \mathrm{Eu}^{*}=0,83\right)$ (Figura 2.16a). As rochas do pórfiro andesítico com anfibólio estão enriquecidas de 50 a 90 vezes no conteúdo de La-Ce em relação ao condrito, apresentam moderada a alta razão $\left([\mathrm{La} / \mathrm{Yb}]_{\mathrm{N}}=5\right.$ a 11,1) e anomalia em $\mathrm{Eu}\left(\mathrm{Eu} / \mathrm{Eu}^{*}=0,8\right.$ a 1 , Figura 2.16c). As rochas do stock de composição quartzo monzodiorítica estão enriquecidas cerca de 90 vezes no conteúdo de La-Ce, apresentam razão $\left([\mathrm{La} / \mathrm{Yb}]_{\mathrm{N}}=6,2\right.$ a 8,4) e razão $(\mathrm{Eu} / \mathrm{Eu} *=0,2$ a 0,25), figura 2.16e. As rochas dos diques estão enriquecidas cerca de 80 a 105 vezes no conteúdo de La-Ce, apresentam razão $\left([\mathrm{La} / \mathrm{Yb}]_{\mathrm{N}}=9,4\right.$ a 11,8) e razão $\left(\mathrm{Eu} / \mathrm{Eu}^{*}=0,5\right.$ a 0,8) (Figura 2.16g). 
Em relação ao diagrama multielementar, normalizados ao condrito, proposto por Thompson (1982), as rochas do pórfiro andesítico com biotita apresentam anomalias positivas nos elementos $\mathrm{Rb}, \mathrm{K}$ e $\mathrm{Tb}$, anomalias negativas nos elementos $\mathrm{Th}, \mathrm{Sr}, \mathrm{Nb}, \mathrm{P}$ e Ti, além de padrão semelhante às rochas de crosta superior, exibindo enriquecimento nos elementos $\mathrm{Rb}$, K, e Sr e empobrecimento em Th, Zr e Hf (Figura 2.16b). Para as amostras do pórfiro andesítico com anfibólio, os elementos Rb e $\mathrm{K}$ apresentam anomalias positivas e os elementos $\mathrm{Th}, \mathrm{Nb}, \mathrm{P}$ e $\mathrm{Ti}$ apresentam anomalias negativas, gerando um padrão multielementar intermediário aos de crosta superior e média, com enriquecimento em nos elementos $\mathrm{Rb}$ e $\mathrm{K}$, e empobrecimento nos elementos Ta, Ce, $\mathrm{Sm}$ e $\mathrm{Zr}$ (Figura 2.16d).

As amostras do quartzo monzodiorito apresentam anomalias positivas nos elementos $\mathrm{Rb}$ e $\mathrm{K}$ e negativas nos elementos $\mathrm{Th}, \mathrm{Nb}$ e $\mathrm{Ti}$, exibindo um padrão semelhante ao de crosta superior, com enriquecimento em $\mathrm{P}$ e empobrecimento em $\mathrm{Tb}$, figura (Figura 2.16f). As rochas dos diques e sills exibem o maior número de discordâncias, onde se observam anomalias positivas nos elementos Th e Sm, enquanto na outra amostra estes elementos exibem anomalias negativas. Apesar das divergências, os elementos $\mathrm{Rb}, \mathrm{Nd}$, e $\mathrm{Tb}$ exibem anomalias positivas nas duas amostras e os elementos $\mathrm{Nb}$, Sr, P e Ti exibem anomalias negativas em ambas as amostras também. O padrão observado é semelhante ao observado nas rochas formadas na crosta superior, com enriquecimento em $\mathrm{Rb}$, Th e K e empobrecimento nos elementos Nb, Sr e Tb (Figura 2.16h). 
"O Sistema Magmático do Depósito de Cu-Mo Tipo Pórfiro Pancho Árias, Cordilheira Oriental, Argentina" Rafael Bellozupko Stremel
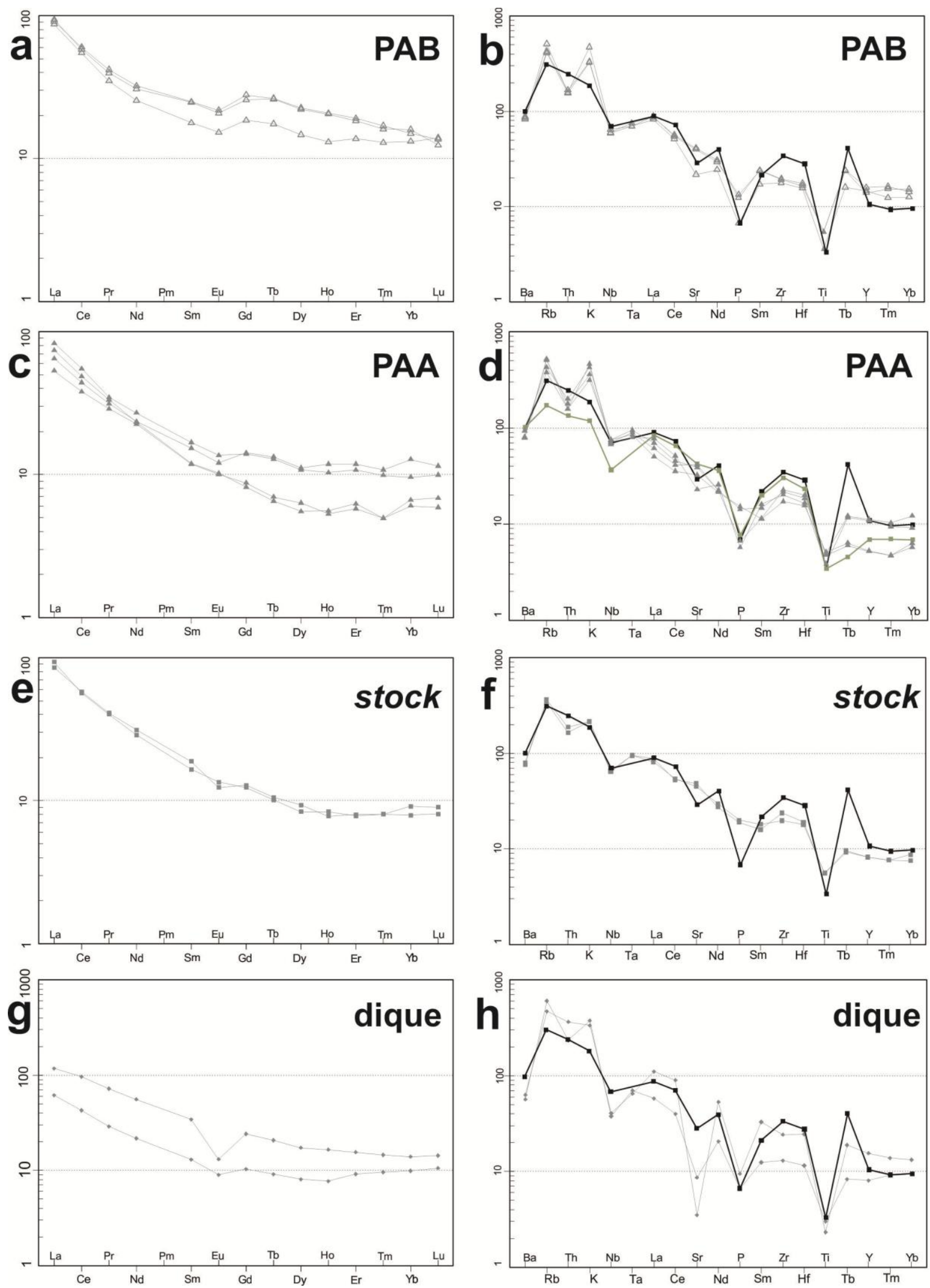

Figura 2.16- a, c, e, g) Diagramas de padrão dos ETR dos pórfiros andesíticos, quartzo monzodiorito e diques respectivamente, normalizados à condrito, proposto por Boynton (1984). b, d, f, h). Diagrama de padrão multielementar dos pórfiros andesíticos, quartzo monzodiorito e diques, respectivamente, proposto por Thompson (1982). Em cinza padrões das amostras, em preto padrões da crosta superior e em verde, padrão da crosta média. 
"O Sistema Magmático do Depósito de Cu-Mo Tipo Pórfiro Pancho Árias, Cordilheira Oriental, Argentina"

Rafael Bellozupko Stremel

\subsection{Química Mineral}

Foram realizadas investigações de microssonda em diversas fases minerais presentes nas rochas correspondentes aos membros magmáticos, as rochas encaixantes e aos corpos de brecha presentes no depósito Pancho Árias. Essa investigação gerou um espectro com 166 resultados divididos em 11 fases minerais distintas, entre estas fases há a presença de silicatos, sulfetos, óxidos e carbonatos.

\subsubsection{Plagioclásio}

Para a fase mineral correspondente ao plagioclásio foram realizadas 23 análises em seis amostras distintas. Esta investigação teve como objetivo verificar a variação composicional destes minerais entre os membros magmáticos, bem como a variação ocasionada pela zonação interna do mineral. Para auxiliar nesta interpretação foram confeccionados dois diagramas de classificação de plagioclásios, um com a variação entre as amostras analisadas (Figura 2.17a) e outro com variação entre as análises de centro e de borda dos cristais (Figura 2.17b).

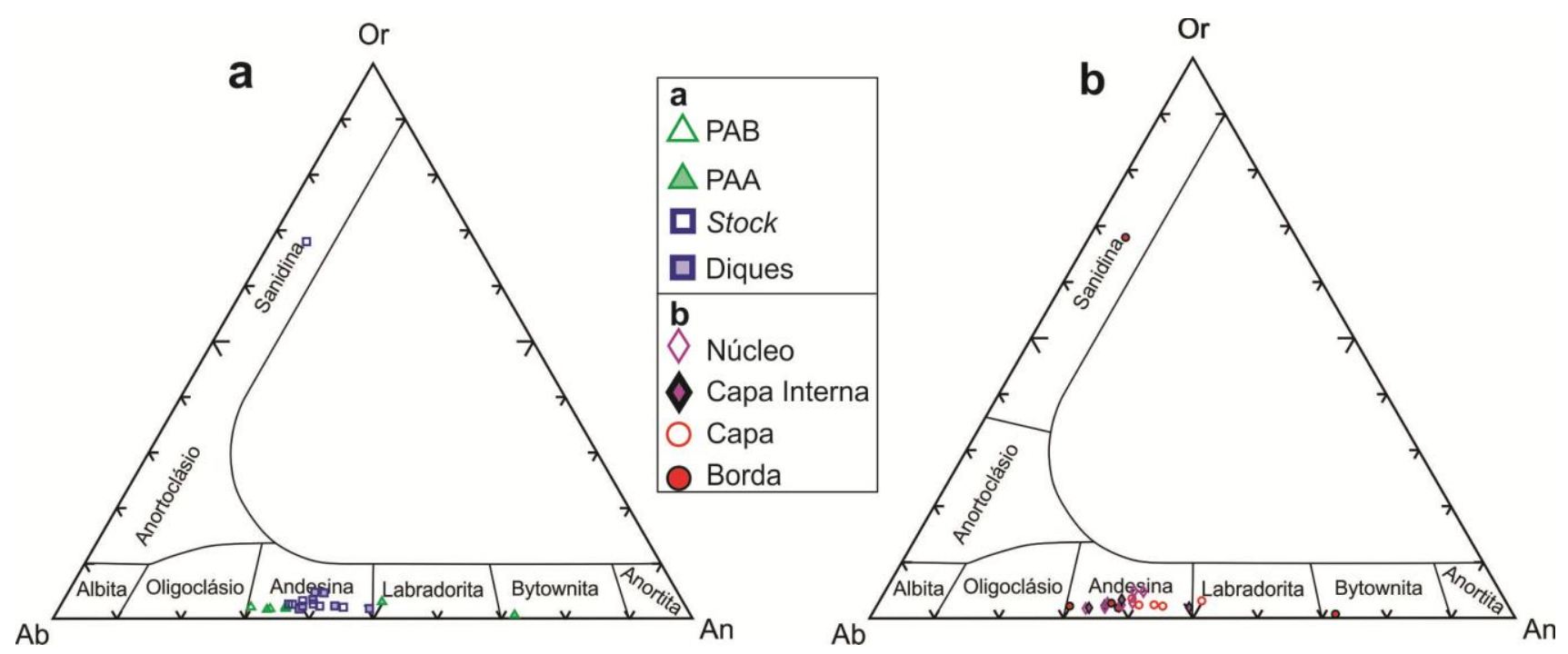

Figura 2.17- a) Diagrama ternário de classificação de plagioclásio (Albita-Anortita-Ortoclásio) para as diferentes amostras analisadas. b) Diagrama ternário de classificação de plagioclásio (Albita-Anortita-Ortoclásio) para os diferentes setores analisados nos grãos.

Das 23 análises realizadas, 6 correspondem ao pórfiro andesítico com biotita e possuem teores de $\mathrm{An}_{30-35}$ e são classificadas como andesina, 2 são de rochas do pórfiro andesítico com anfibólio e possuem teores de $\mathrm{An}_{50-72}$, sendo classificadas como labradorita e bytownita, 7 são de 
"O Sistema Magmático do Depósito de Cu-Mo Tipo Pórfiro Pancho Árias, Cordilheira Oriental, Argentina"

Rafael Bellozupko Stremel

rochas do stock e teores de $\mathrm{An}_{35-44}$ e são classificadas como andesina e 8 de rochas dos diques, com teores de $\mathrm{An}_{37-48}$, sendo classificadas como andesina.

Para análise da variação composicional pela zonação dos cristais, cada fenocristal de plagioclásio foi subdividido em quatro porções, denominados como núcleo, capa interna, capa e borda, como proposto por Pringle et al. (1974). No núcleo dos cristais o teor varia de $\mathrm{An}_{40-33}$, na capa interna de $A n_{48-35}$, na capa externa de $A n_{49-33}$ e na borda de $A n_{72-30}$ (Figura 2.17b). Nessa divisão os quatro campos dos fenocristais mostram-se geralmente homogêneos, ou seja, sem marcante mudança na composição mineral. A exceção são os fenocristais do pórfiro andesítico com anfibólio, que apresentam enriquecimento no teor de anortita da capa para a borda do cristal (An-50 para An-72).

\subsubsection{Biotita}

Foram realizadas 33 análises em cristais de biotita, as quais aos pórfiros andesíticos e stock. Essas análises tiveram como objetivo diferenciar composicionalmente as biotitas entre os membros magmáticos, diferenciar a composição das biotitas hidrotermais das magmáticas, e analisar a variação composicional causada pela alteração de borda presente em alguns fenocristais.

Para separar as biotitas entre os membros magmáticos, foi utilizado um diagrama linear $\mathrm{Mg} \mathrm{x}$ Fe que diferenciou três campos bem definidos, um para cada fase magmática analisada. No pórfiro andesítico com biotita, as biotitas analisadas possuem os menores teores em $\mathrm{Mg}^{2+}$ e $\mathrm{Fe}_{\text {tot }}(2,5$ a 3,2 apfu e 1,5 a 2,3 apfu, respectivamente. No pórfiro andesítico com anfibólio os teores de $\mathrm{Mg}$ variam entre 3 e 3,7 apfu e os teores de Fe variam entre 1,8 e 2,6 apfu, exibindo valores intermediários em relação as outras fases. Já as rochas do stock possuem teores de $\mathrm{Mg}$ variando entre 3 e 4,2 apfu e de Fe entre 2,3 e 3,2 apfu, exibindo teores mais enriquecidos nestes dois elementos (Figura 2.19a). Observa-se ainda, que nos pórfiros andesíticos os teores de $\mathrm{Fe}_{\text {tot }}$ decrescem com o aumento do teor de $\mathrm{Mg}^{2+}$, enquanto nas rochas do stock os valores de um elemento crescem junto com o aumento do outro. Para a classificação das biotitas, foi utilizado o diagrama $(\mathrm{Mg} / \mathrm{Fe}+\mathrm{Mg}$ x Al total proposto por Hey's (1954). Nesta proposta, a grande maioria dos cristais analisados foram classificados como flogopita, apenas duas análises do quartzo - monzodiorito foram classificados como eastonita, e três do P1 como annita (Figura 2.18b). 
"O Sistema Magmático do Depósito de Cu-Mo Tipo Pórfiro Pancho Árias, Cordilheira Oriental, Argentina" Rafael Bellozupko Stremel
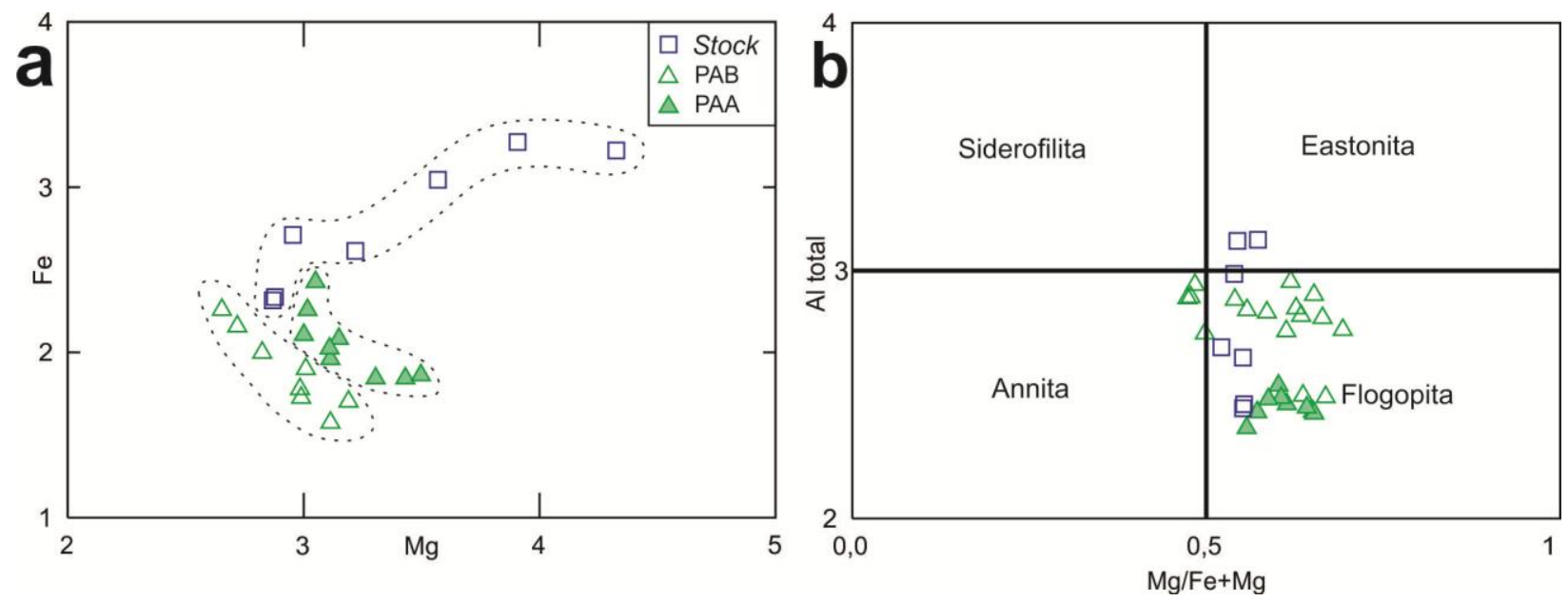

Figura 2.18 - a) Diagrama $\mathrm{Mg}^{2+}$ x Fe para os grãos de biotita analisados, exibindo três campos bem definidos. b) Diagrama $\mathrm{Mg} / \mathrm{Fe}+\mathrm{Mg}$ x Al total para classificação de biotitas, proposto por Hey's (1954).

\subsubsection{Clorita}

Para a fase mineral representada pela clorita, foram realizadas doze análises em duas amostras distintas, uma representante do stock (PA 201) e outra dos diques. Para a classificação destas cloritas foi utilizado o diagrama Si (apfu) x Fe/Fe+Mg proposto por Hey's (1954). Nesta classificação foram diferenciados dois grupos, um de ripidolita, para as amostras do stock e outro de proclorita, para as amostras dos diques (Figura 2.19).

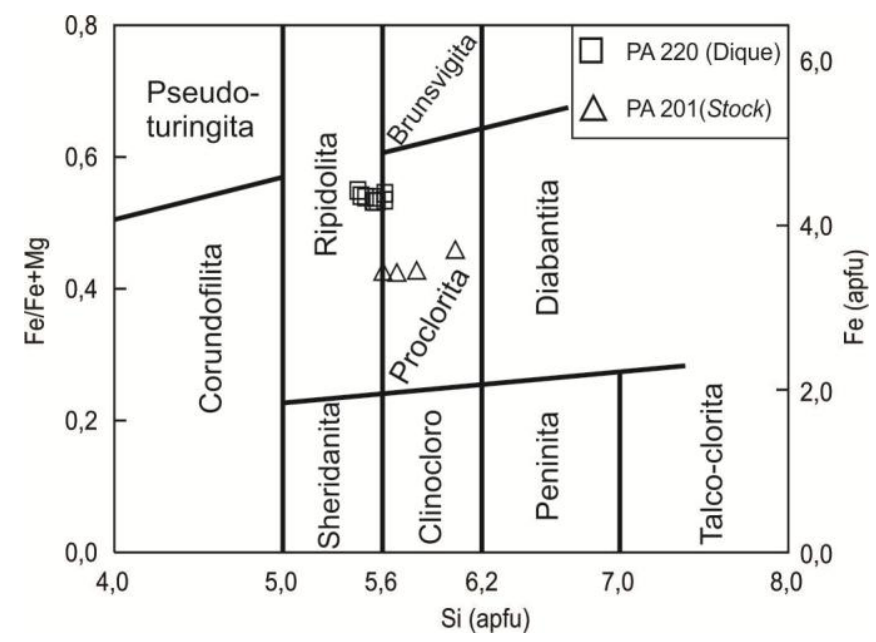

Figura 2.19 - Diagrama Si(afpu) x Fe/Fe+Mg para classificação de cloritas. Proposto por Hey's, 1954. 
"O Sistema Magmático do Depósito de Cu-Mo Tipo Pórfiro Pancho Árias, Cordilheira Oriental, Argentina" Rafael Bellozupko Stremel

\subsubsection{Anfibólio}

Foram realizadas 8 análises em grãos de anfibólio, em duas amostras distintas, PA 201 correspondente ao stock quartzo-monzodiorito e PA 221, correspondente aos diques. As análises revelaram teores de Si entre 7 e 7,3 apfu, $\mathrm{Al}^{\mathrm{IV}}$ entre 0,7 e 1 apfu, Ca entre 1,7 e 1,9 apfu, Na 0,15 e $0,27 \mathrm{apfu}, \mathrm{K}$ entre 0,06 e 0,1 apfu e razão $\mathrm{Mg} / \mathrm{Mg}+\mathrm{Fe}^{2+}$ entre 0,8 e 0,84 . Grãos de anfibólio com teores de $\mathrm{Ca}$ maiores que 1,5 e teores de $\mathrm{Na}+\mathrm{K}$ menores que 0,5 são classificados como anfibólios cálcicos e utiliza-se o diagrama ( $\mathrm{Si}$ x $\mathrm{Mg} / \mathrm{Mg}+\mathrm{Fe}^{2+}$ ) proposto por Leake et al. (1997), para classificalos (Figura 2.20). Para esta classificação, todos os grãos analisados foram classificados como Mghornblenda.

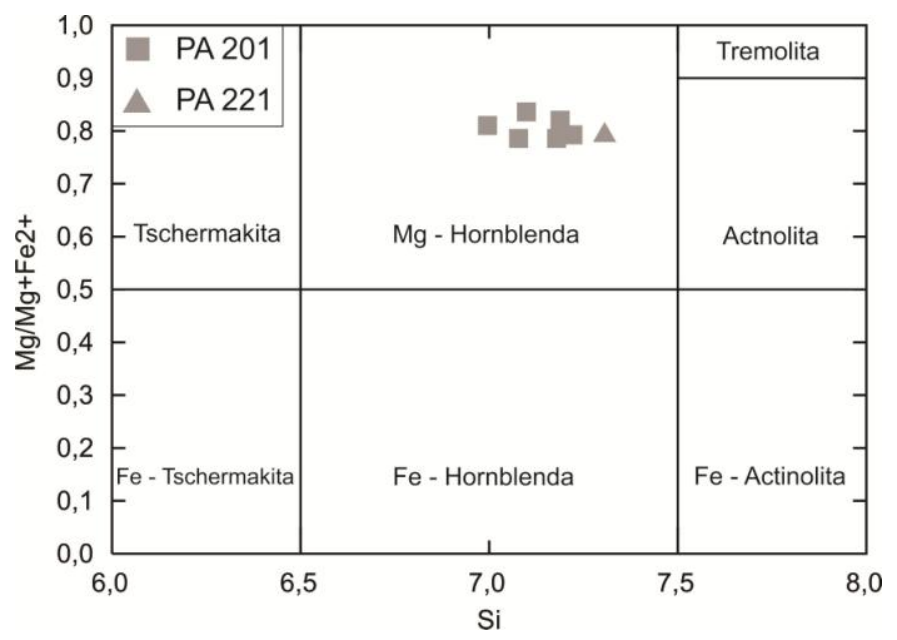

Figura 2.20- Diagrama $\mathrm{Si}(\mathrm{apfu}) \times \mathrm{Mg} / \mathrm{Mg}+\mathrm{Fe}^{2+}$ para a classificação de anfibólios cálcicos, proposto por Leake et al., 1997.

\subsubsection{Mica Branca e Carbonato}

Para estas duas fases minerais, foram realizadas nove análises em duas amostras distintas, todas correspondentes aos diques e sills com alteração hidrotermal do tipo propilítica. Ambos minerais são formados pela desestabilização de minerais primários, com o carbonato sendo produto da alteração da clorita e a mica branca sendo resultado da desestabilização do plagioclásio e também da clorita. As análises foram realizadas para simples confirmação das interpretações realizadas através da petrografia e o volume de dados não é suficiente para a utilização de diagramas binários ou de classificação (Anexos 3 e 4). 
"O Sistema Magmático do Depósito de Cu-Mo Tipo Pórfiro Pancho Árias, Cordilheira Oriental, Argentina"

Rafael Bellozupko Stremel

\subsection{Discussão}

As relações de campo e características texturais permitiram diferenciar quatro membros magmáticos distintos, três subvulcânicos e co-genéticos, representados pelos pórfiros andesíticos e sistema de diques e sills riodacíticos a traqui-andesíticos e uma fase plutônica, representada pelo stock de composição quartzo monzodiorítica.

As relações de intrusão entre os pórfiros andesíticos e as rochas metassedimentares da Formação Puncoviscana nos permite inferir que a sequência de eventos intrusivos se inicia com a intrusão de pequenos diques do pórfiro com biotita nas rochas encaixantes, este evento é seguido de um evento intrusivo de maior porte, onde a intrusão do pórfiro com anfibólio gera corpos de brecha com fragmentos das três litologias. A textura porfirítica dos dois membros, associados a estruturas do tipo roof-pendant, plugs, densa venulação, stockwork e diques permite inferir que estes eventos ocorreram em porções superiores da crosta e tiveram rápido resfriamento, condições características de teto de câmara magmática (Sillitoe, 2010). O arranjo microtextural dessas rochas é tipicamente sub-vulcânico, onde os fenocristais exibem diversas feições de reação com o melt (golfos de corrosão, bordas corroídas, alteração de borda e cordões de quartzo) e a trama quartzo feldspática que compõe a matriz comumente é afetada por alteração hidrotermal e formação de veios e vênulas de quartzo, feições características de depósitos do tipo pórfiro (Sillitoe, 2010; Sinclair; 2007).

O stock quartzo monzodiorítico se assemelha à fácies monzodiorito com anfibólio e biotita do plúton Las Burras, descrito por Cavalleri (2005). Esse corpo possui idade U-Pb de aproximadamente $14 \mathrm{Ma}$ e, portanto, é mais novo do que os pórfiros andesíticos. Assim, nós sugerimos o alojamento desse stock no depósito Pancho Árias como um provável plug associado ao magmatismo Las Burras, que aflora cerca de $7 \mathrm{~km}$ ao sul da área em estudo.

O arranjo textural e a distribuição dos corpos de brecha permitiram a separação desses seis corpos em dois grandes grupos, os corpos do centro-nordeste possuem fragmentos dos pórfiros andesíticos e clara relação com esses eventos intrusivos e sua distribuição espacial coincide com as bordas das intrusões, podendo classifica-las como brechas relacionadas a sistemas pórfiros, descritos por Sillitoe (1985). As brechas do setor centro-nordeste possuem ainda, sulfetos na matriz e nos fragmentos, podendo ser classificadas como brechas interminerais Sillitoe (1985). Já as brechas localizadas no setor centro-sudoeste tendem a ser monomíticas, são corpos sub-circulares com leve elongação, possuem óxidos e até turmalina na matriz, além de possuir textura do tipo jigsaw e podem ser descritos como brechas hidrotermais, proposto por Corbett \& Leach (1998) e Sillitoe (1985). Este tipo de corpo de brecha possui relação genética com stocks inalterados e não mineralizados, logo 
"O Sistema Magmático do Depósito de Cu-Mo Tipo Pórfiro Pancho Árias, Cordilheira Oriental, Argentina"

Rafael Bellozupko Stremel

podem estar relacionados ao stock quartzo monzodiorítico e desvinculados do sistema Cu-Mo pórfiro das brechas do centro-nordeste, Martín (2007).

A análise geoquímica referente aos pórfiros andesíticos exibem assinatura geoquímica de traquiandesito, as amostras do stock de quartzo diorito e as amostras dos diques de riodacitos a traqui-andesitos. Essas rochas são essencialmente peraluminosas, com exceção do quartzo monzodiorito que é metaluminoso, cálcio-alcalinas a álcali-cálcicas e magnesiana, que compreende os granitos de cordilheira, ou tipo I, apresentando estreita afinidade com magmas oxidantes e relativamente hidratados, comuns em ambientes convergentes, caracterizados por zonas de subducção e arco de ilha (Frost et al., 2001).

Em relação ao padrão dos elementos terras raras (ETR), as rochas estão enriquecidas de 50 a 90 vezes nos ETR pesados em relação ao condrito, exibem leve fracionamento dos ETR leves em relação aos pesados e discreta anomalia em Eu. O padrão multielementar assemelha-se ao padrão de crosta superior e as anomalias presentes (positivas em $\mathrm{U}, \mathrm{K}$ e Th e negativas em $\mathrm{Ba}, \mathrm{Nb}, \mathrm{P}$ e Ti) essa assinatura geoquímica é característica de rochas formadas em contexto de arco magmático, com moderado nível de contaminação crustal.

A química mineral do plagioclásio exibiu grande predomínio de andesina, plagioclásio mais comum em pórfiros da série cálcio-alcalina, e foi essencial para compreender o tipo de zonação que esse mineral apresenta. $\mathrm{O}$ teor de anortita é controlado pela temperatura, pressão e conteúdo em $\mathrm{H}_{2} \mathrm{O}$ do magma e pelo teor de anortita do magma parental (Hattori \& Sato, 1996; Johannes, 1978; Housh \& Luhr, 1991). A zonação oscilatória em plagioclásios é resultado da interação dos processos de cristalização e difusão quando a difusão cristal-melt ocorre do $\mathrm{Al}^{3+}$ para $\mathrm{Si}^{4+}, \mathrm{Fe}^{3+}$ para $\mathrm{Si}^{4+}$ e do $\mathrm{Ca}^{2+}$ para $\mathrm{Na}^{+}$(L'Heureux \& Fowler, 1994, Figura 2.21). Os diagramas Al vs Si e Ca vs Na, sugerem que a substituição desses elementos afeta os gradientes composicionais no melt perto dos cristais de plagioclásio, resultando na zonação oscilatória (Figura 2.21). A correlação negativa entre $\mathrm{Fe}^{3+} \mathrm{e} \mathrm{Si}^{4+}$ possivelmente indica que a substituição de Fe por Si não é abundante nos fenocristais em estudo e essa difusão foi controlada pela interação e equilíbrio entre o magma derivado do manto depletado (Capítulo 3) e a contaminação crustal. 

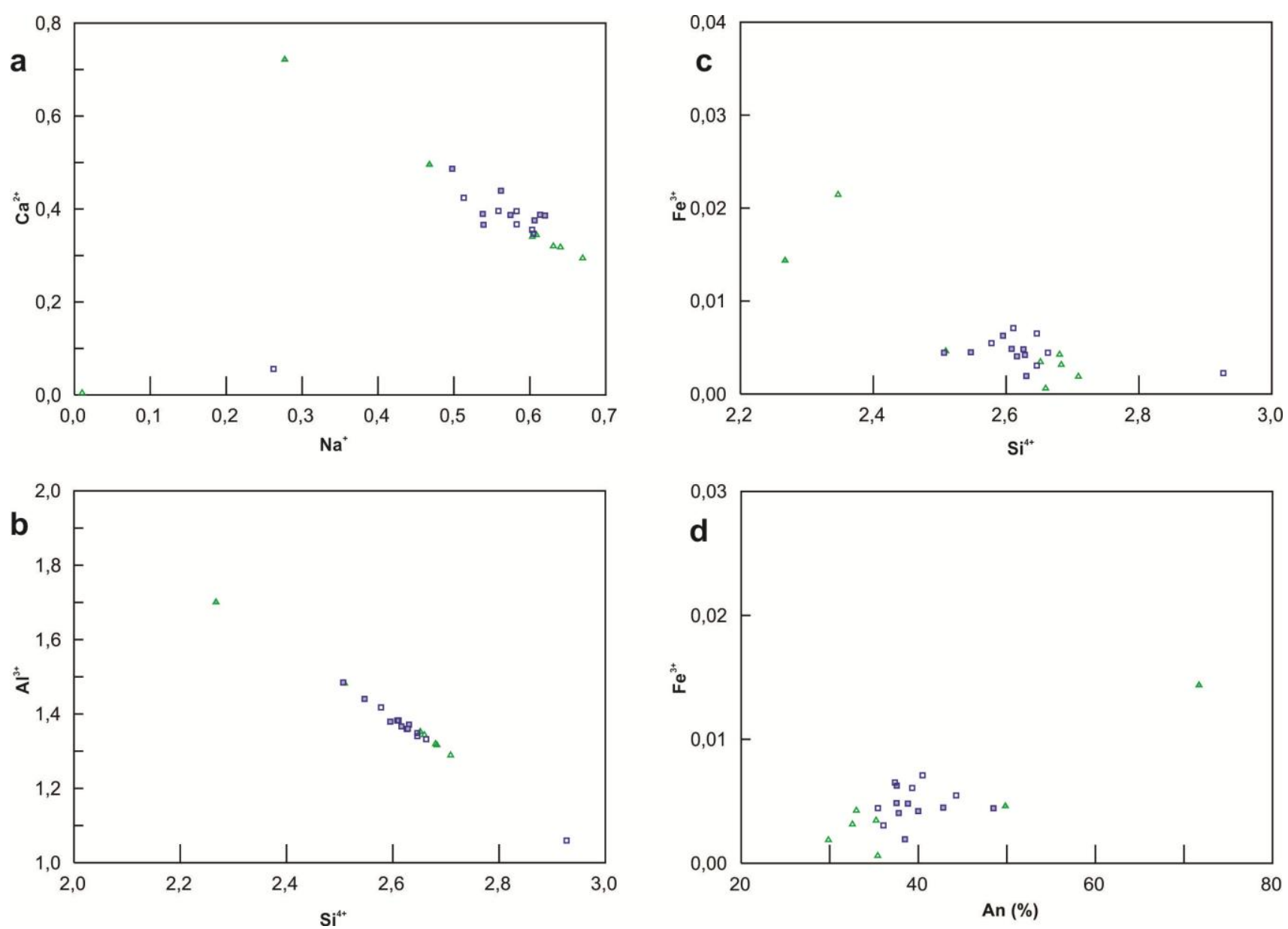

Figura 2.21 - a, b e c ) Mecanismos que exemplificam processo de difusão responsável pela zonação oscilatória dos plagioclásios do depósito Pancho Árias. d) Conteúdo de $\mathrm{Fe}^{3+}$ vs $\mathrm{An}(\%)$ nos plagioclásios zonados. Símbolos iguais da figura 2.19 .

A química mineral dos cristais de biotita magmática é uma importante ferramenta para a determinação das condições de cristalização. As biotitas magmáticas dos pórfiros andesíticos e do stock possuem razão $(\mathrm{FeO} * \mathrm{MgO}=0,95$ e composição de flogopita) e são características de suítes orogênicas cálcio-alcalinas (Figura 2.22), valores que corroboram os dados de geoquímica Haslam (1968). A composição das biotitas é muito eficaz para determinar as condições físico-química magmáticas, especialmente a $f \mathrm{O}_{2}$. A disponibilidade de oxigênio favorece a cristalização inicial de anfibólio e óxidos de Fe, que por sua vez impede a acumulação de Fe em melts cálcio-alcalinos, favorecendo a cristalização de biotita com moderado enriquecimento em $\mathrm{Mg}$. No diagrama $\mathrm{TiO}_{2}$ vs $\mathrm{Al}_{2} \mathrm{O}_{3}$ (Figura 2.22d) as rochas com anfibólio foram classificadas como pertencentes a série da magnetita (elevado $\mathrm{TiO}_{2}$ e baixo $\mathrm{Al}_{2} \mathrm{O}_{3}$ ) e as rochas que não contém anfibólio como pertencente a série da ilmenita (baixo $\mathrm{TiO}_{2}$ e elevado $\mathrm{Al}_{2} \mathrm{O}_{3}$ ).

A química dos anfibólios é característica de magnésio-hornblenda, o anfibólio mais comum formado em condições de séries cálcio-alcalinas. A clorita resultou em dois campos bem definidos, a 
"O Sistema Magmático do Depósito de Cu-Mo Tipo Pórfiro Pancho Árias, Cordilheira Oriental, Argentina" Rafael Bellozupko Stremel

proclorita possui maiores teores de $\mathrm{Mg}$ e é característica das condições de formação das rochas em estudo e a ripidolita é enriquecida em Fe, provavelmente derivado da alteração hidrotermal.
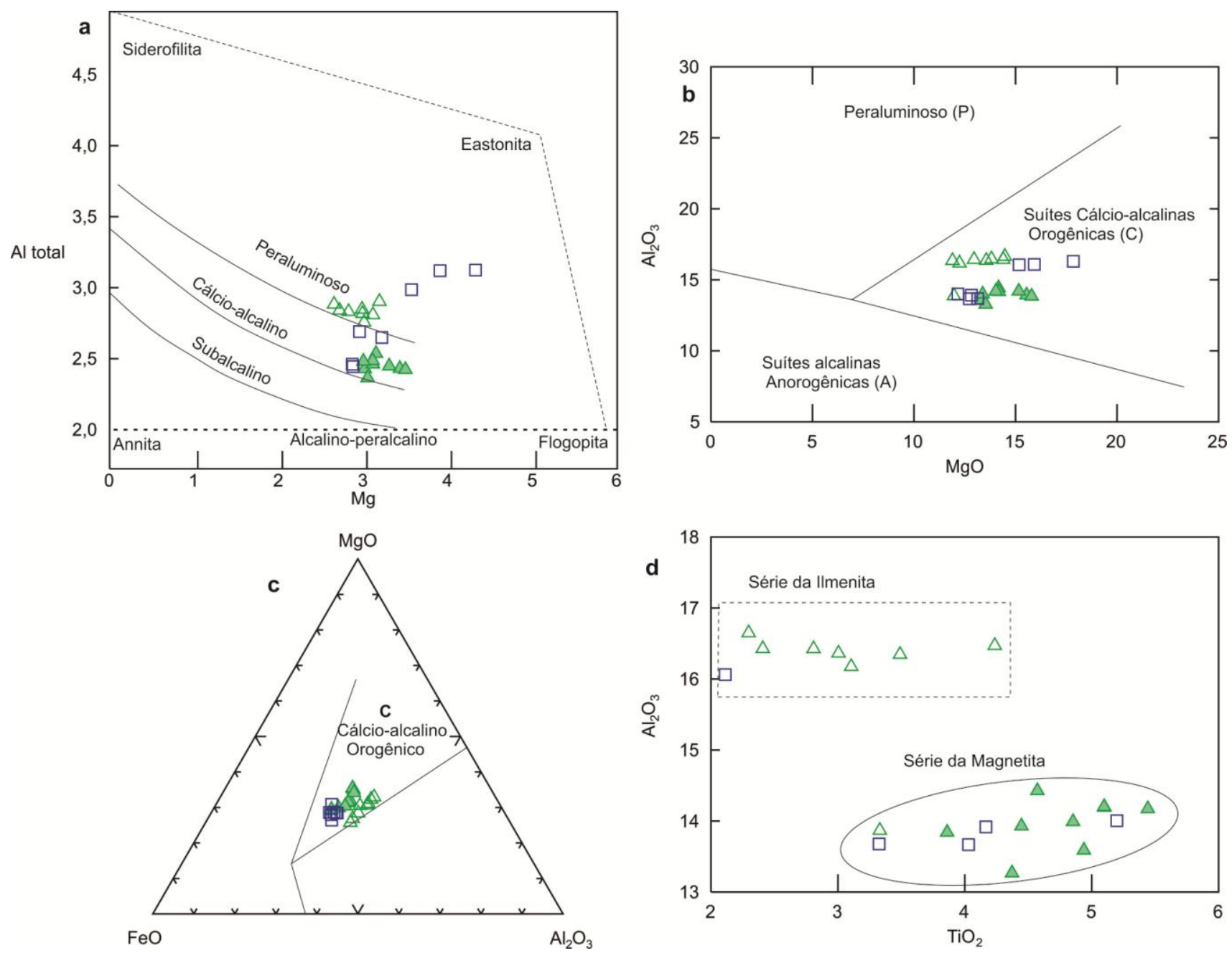

Figura 2.22 - Diagramas de classificação das biotitas analisadas. a, b e c) Classificação em relação as séries magmáticas e ambientes de formação ( Nachit et al., 1985; Abdel-Rahman's, 1994. d) Classificação em relação as séries e condições de oxidação.

Os dados expostos neste capítulo, somados aos dados de zonação hidrotermal e geologia isotópica $\mathrm{Ar}-\mathrm{Ar}, \mathrm{Sm}-\mathrm{Nd}$, que serão apresentados no próximo capítulo, servirão de embasamento teórico para o modelo magmático e metalogenético que será proposto no trabalho. 
"O Sistema Magmático do Depósito de Cu-Mo Tipo Pórfiro Pancho Árias, Cordilheira Oriental, Argentina" Rafael Bellozupko Stremel

\section{CAPÍTULO 3}

\subsection{Sistema de Alteração Hidrotermal}

O sistema de alteração hidrotermal que afeta as rochas do depósito Pancho Árias é do tipo zonal concêntrico, com contatos transicionais, irregulares e descontínuos entre as diferentes zonas identificadas. Esse sistema zonal de alteração se sobrepõe aos contatos litológicos e é marcado sobretudo por três zonas distintas: a) uma potássica ao centro; b) uma sericítica intermediária; e c) uma propilítica externa (Figura 3.1).
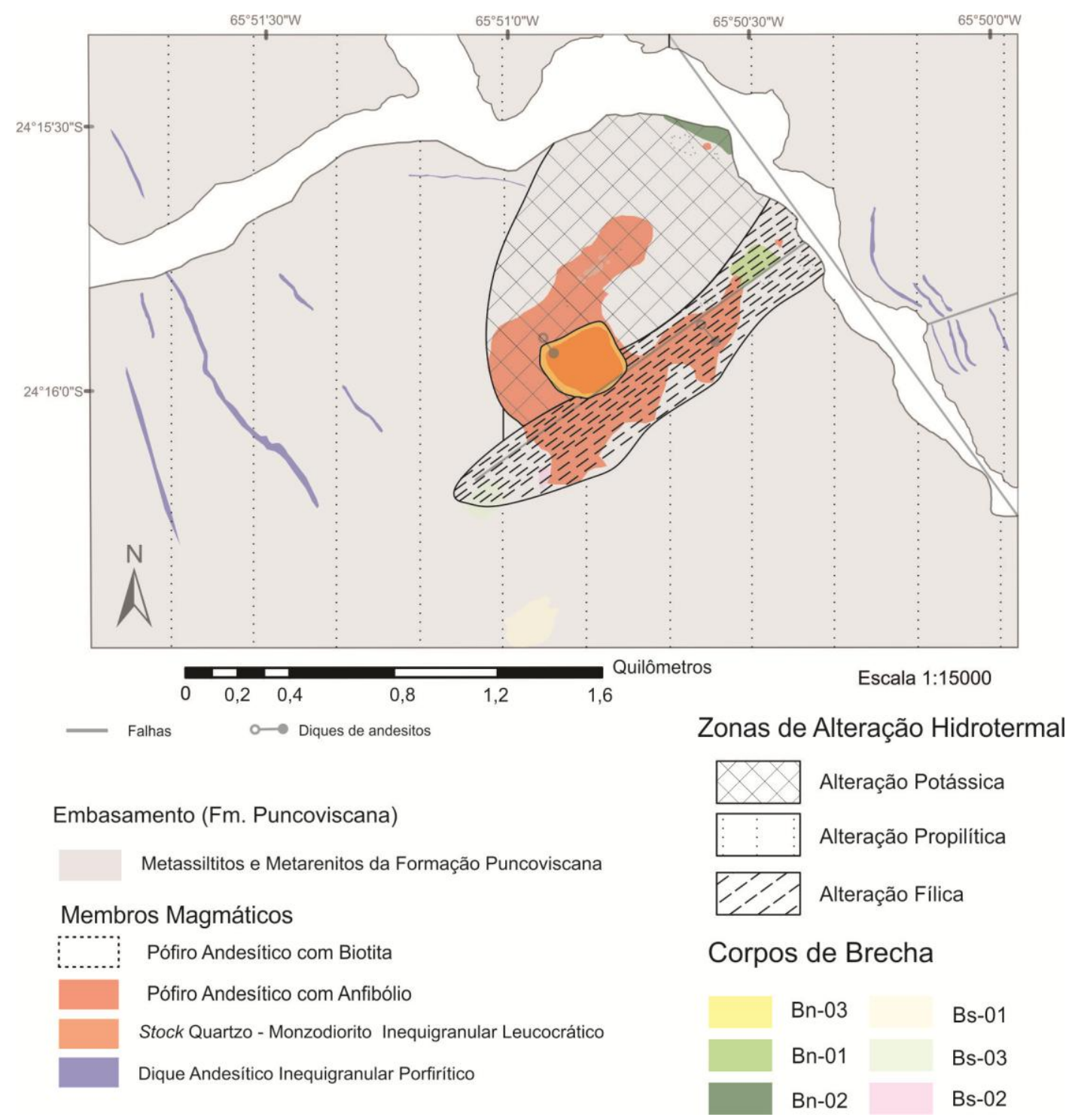

Figura 3.1- Mapa de alteração hidrotermal do depósito Cu-Mo Pancho Árias, ressaltando as três zonas e as litologias presentes. 
"O Sistema Magmático do Depósito de Cu-Mo Tipo Pórfiro Pancho Árias, Cordilheira Oriental, Argentina" Rafael Bellozupko Stremel

\subsubsection{Alteração Potássica}

A alteração hidrotermal potássica ocorre na porção centro-norte da área, associada ao local denominado de Cerro Pancho Arias (Figura 2.1) e afeta os dois pórfiros andesíticos, as rochas metassedimentares encaixantes da Formação Puncoviscana, além dos corpos de brecha localizados neste setor do depósito (Figura 3.1). Esse tipo de alteração manifesta-se no pórfiro andesítico com anfibólio principalmente sob a forma de microagregados de cristais de biotita que substituem cristais de hornblenda, segundo a reação metassomática (1), definida por Barnes (1967). Outras feições microscópicas associadas a essa alteração, é a presença de agregados microcristalinos de biotita na matriz, além da geração de fases ricas em K, representada por ortoclásio envolvendo parcialmente fenocristais de plagioclásio (Figura 3.2b). Nessa fase o teor de microclínio aumenta aproximadamente de $2 \%$ para $35 \%$, a qual é caracterizada pela expansão de volume do cristal primário (8,6\% para albita e $13,4 \%$ para anortita e quartzo) e pode ser sumarizada pelas equações metassomáticas (2) e (3) abaixo descritas (Orville, 1963; Deng, 1986; Collins, 1996).

$$
\begin{aligned}
& \mathrm{Fe}^{3+}+2 \mathrm{~K}^{+}+\mathrm{CaFe}_{5} \mathrm{Al}_{2} \mathrm{Si}_{7} \mathrm{O}_{22}(\mathrm{OH})_{2}+2 \mathrm{H}_{2} \mathrm{O}=2 \mathrm{KFe}_{3} \mathrm{AlSi}_{3} \mathrm{O}_{10}(\mathrm{OH})_{2}+\mathrm{SiO}_{2}+\mathrm{Ca}^{2+}+2 \mathrm{H}^{+}(1) \\
& \text { (Anfibólio) (Biotita) }
\end{aligned}
$$

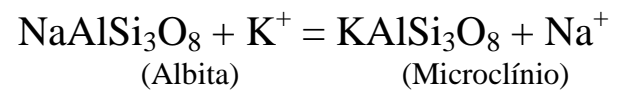

$$
\begin{aligned}
& \underset{\text { (Anortita) }}{\mathrm{CaAl}_{2} \mathrm{Si}_{2} \mathrm{O}_{8}+4 \mathrm{SiO}_{2}}+\underset{\text { (Microclínio) }}{2 \mathrm{~K}^{+}}=\underset{\mathrm{Ca}^{2+}}{2 \mathrm{KAlSi}_{3} \mathrm{O}_{8}}
\end{aligned}
$$

No pórfiro andesítico com biotita a alteração potássica apresenta-se principalmente sob a forma de agregados de microcristais de biotita disseminados na trama quartzo-feldspática da matriz da rocha (Figuras 3.2a). Na rocha encaixante e nos corpos de brecha a alteração é caracterizada pela formação de cristais anedrais de biotita disseminados na trama da rocha (Figura 3.2d). 


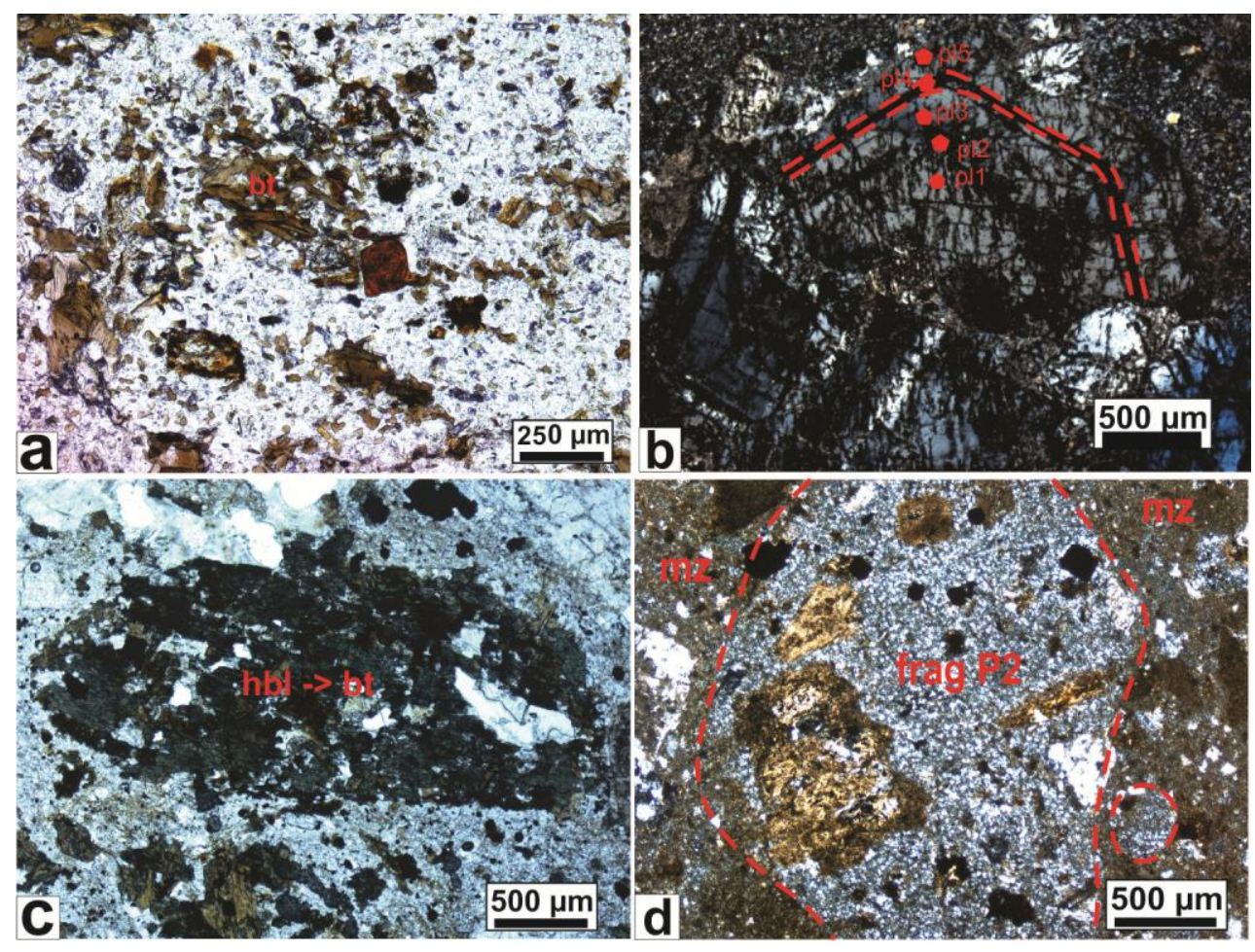

Figura 3.2- Nicóis paralelos: N//, nicóis cruzados: $\mathrm{NX}, \mathrm{Bt}=$ biotita, $\mathrm{Hbl}=$ hornblenda, $\mathrm{Mz}=$ matriz, Frag = fragmento. a) $4 \mathrm{x}, \mathrm{N} / /$. Detalhe de aglomerado de cristais anedrais de biotita formados na trama quartzo-feldspática da fase magmática P1, figura repitida da 2.4f. b) 4x, NX. Detalhe da zonação do plagioclásio, ressaltando faixa rica em K. c) Fenocristal de Mg-Hornblenda parcialmente substituído para biotita, figura repetida da 2.5a. d) Detalhe de fragmento disperso em matriz composta por quartzo, sericita e biotita, resultado da alteração hidrotermal potássica, figura repetida da $2.10 \mathrm{~d}$.

$\mathrm{O}$ diagrama ternário $\mathrm{MnO}+\mathrm{FeO} \times 10 \times \mathrm{xiO}_{2} \times \mathrm{MgO}$, proposto por Nachit et al. (2005), é subdivido em três campos principais (Figura 3.3). O campo (A) corresponde as biotitas magmáticas primárias, o campo (B) representa as biotitas reequilibradas e o campo (C) corresponde as biotitas neoformadas. As biotitas plotadas no campo (A) agruparam-se nos subcampos 3, 4 e 5 e possuem teores de $\mathrm{MnO}+\mathrm{FeO}$ entre 0,5 e 0,8, esses subcampos são característicos de biotitas magmáticas, caracterizadas por cristais euédricos, com cor marrom e forte pleocroísmo. O campo (B) de biotitas neoformadas, é caracterizado pelo decréscimo no teor de $\mathrm{TiO}_{2}$ os grãos de biotita reequilibrada possuem menor cor marrom, menor intensidade de pleocroísmo e apresentam formação de óxidos de titânio em suas bordas e planos de clivagem. Observa-se que nesse diagrama não foi possível separar claramente as micas magmáticas das hidrotermais. Tal fato, segundo Corbett \& Leach (1998), pode ser explicado devido à alteração hidrotermal nos sistemas pórfiros gerar micas (biotita) hidrotermais com composição química semelhante as das biotitas magmáticas.

Segundo Nachit et al. (2005), o campo (C) é representado por biotitas neoformadas, estes grãos são os que possuem menor teor de $\mathrm{TiO}_{2}$ e geralmente se formam em porosidades da rocha sob a forma de aglomerados de grãos anedrais. 


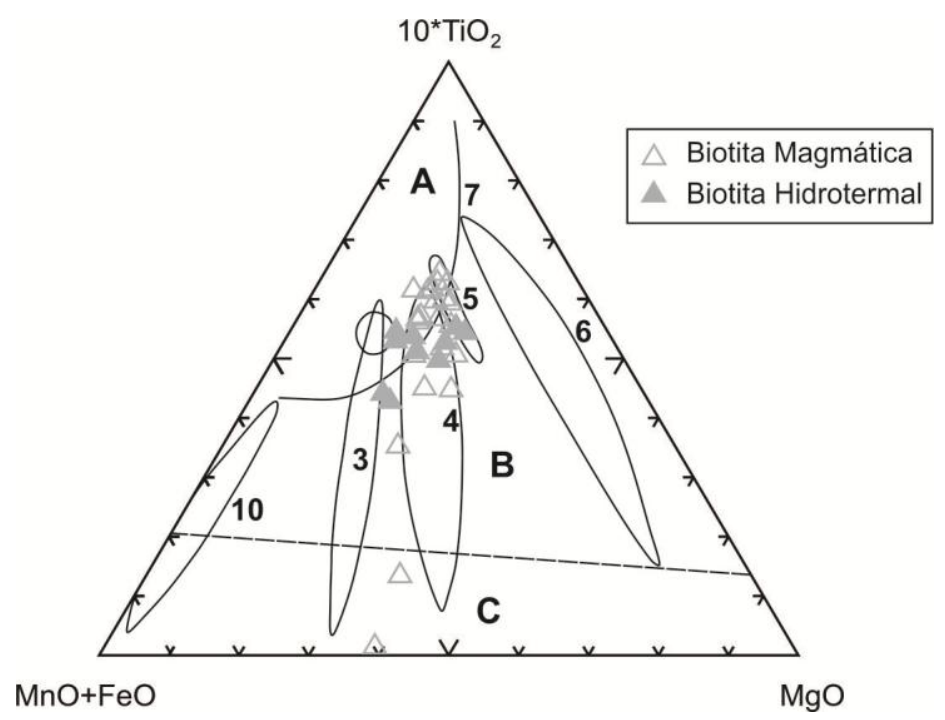

Figura 3.3- Diagrama triangular $\left(\mathrm{MnO}+\mathrm{FeO} \times 10 \times \mathrm{TiO}_{2} \times \mathrm{MgO}\right)$ para classificação de biotitas primárias, reequilibradas e neoformadas, proposto por Nachit et al. (2005).

\subsubsection{Alteração Sericítica}

A alteração hidrotermal sericítica ocorre associada ao local denominado Quebrada de Soquero, possui geometria com elongação NE-SW, localiza-se nas bordas da porção sul e leste da alteração potássica, afetando o pórfiro andesítico com anfibólio, as rochas encaixantes e corpos de brecha, além de ocorrer de forma sobreposta à alteração hidrotermal potássica. No pórfiro andesítico, se apresenta sob a forma de microgrãos anedrais de sericita que substituem parcial a totalmente os fenocristais de biotita e plagioclásio (Figura 3.4a), resultado da equação química (4), Hemley \& Jones (1964). Nas rochas encaixantes e nos corpos de brecha formam cristais subedrais de sericita que se desenvolvem de forma caótica, "manchando" de forma indiscriminada todo o arranjo microcristalino (Figura 3.4b).

$0,75 \mathrm{Na}_{2} \mathrm{CaAl}_{4} \mathrm{Si}_{8} \mathrm{O}_{24}+2 \mathrm{H}^{+}+2 \mathrm{~K}^{+}=\mathrm{KAl}_{2} \mathrm{Si}_{3} \mathrm{O}_{10}(\mathrm{OH})_{2}+1,5 \mathrm{Na}^{+}+0,75 \mathrm{Ca}^{2+}+3 \mathrm{SiO}_{2}$ 


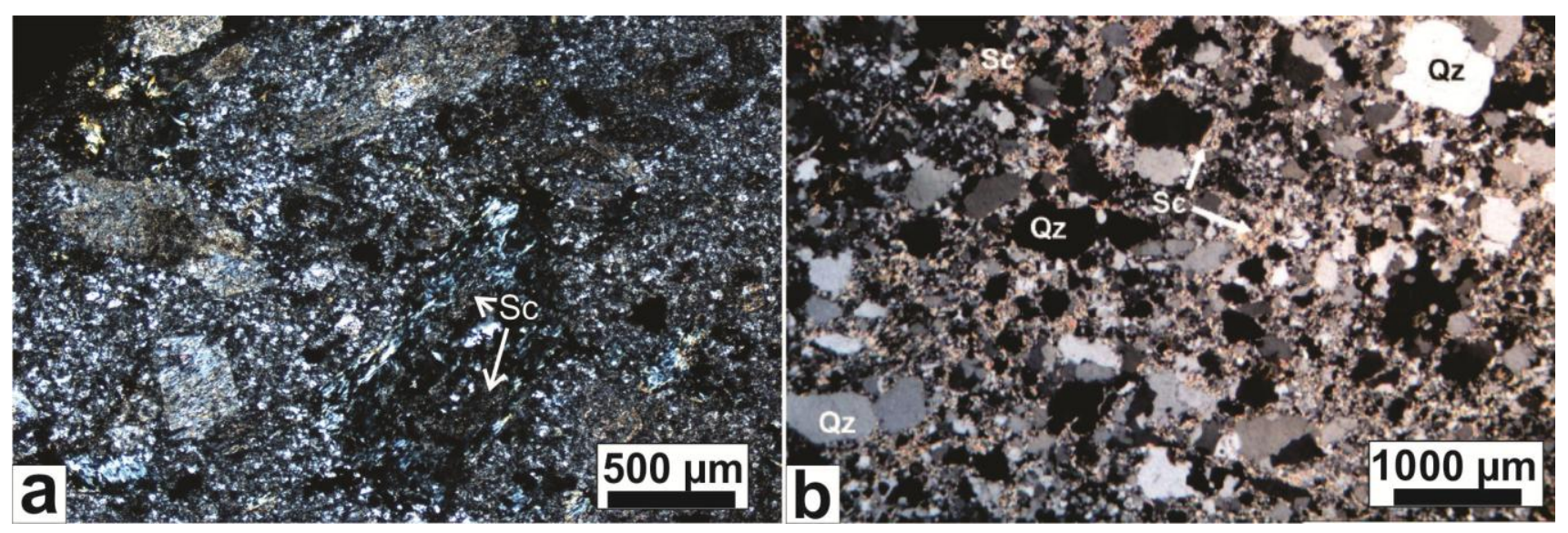

Figura 3.4- Nicóis paralelos: N//, nicóis cruzados: $\mathrm{NX}, \mathrm{Sc}=$ serecita e $\mathrm{Qz}=$ quartzo. Fotomicrografias em nicóis cruzados. a) Detalhe de fenocristal de plagioclásio totalmente substituído para sericita, resultante da alteração hidrotermal sericítica. b) Detalhe da formação de sericita na estrutura da rocha encaixante, Martín (2007).

\subsubsection{Alteração Propilítica}

A alteração hidrotermal propilítica ocorre nas porções externas da área de estudo, sendo um halo que circunda as alterações potássica e sericítica. É a maior e mais marcante zona de alteração e afeta o sistema de diques e sill, além das rochas metassedimentares da Formação Puncoviscana. Os diques são os mais afetados pela alteração propilítica, onde essa se expressa sob a forma de parcial a total cloritização dos fenocristais de biotita, segundo a equação química (5), Barnes (1967), (Figuras 3.5c, 3.5d, 3.5e). Há também a formação de cristais de epidoto nas bordas dos fenocristais e na matriz, formação de calcita secundária na matriz (Figura 3.5a) e como produto de substituição da clorita (Figura 3.5d, 3.56e), além de substituição dos fenocristais de plagioclásio para sericita. De maneira menos pervasiva, afeta também as rochas do embasamento, onde se formam microcristais de clorita e epidoto ao longo de planos de fraturas.

$$
\begin{aligned}
& 2 \mathrm{~K}(\mathrm{Mg}, \mathrm{Fe})_{3} \mathrm{AlSi}_{3} \mathrm{O}_{10}(\mathrm{OH})_{2}+4 \mathrm{H}^{+}=\mathrm{Al}(\mathrm{Mg}, \mathrm{Fe})_{5} \mathrm{AlSi}_{3} \mathrm{O}_{10}(\mathrm{OH})_{8}+2 \mathrm{~K}^{+}+(\mathrm{Mg}, \mathrm{Fe})_{2}{ }^{2+}+3 \mathrm{SiO}_{2}(5) \\
& \text { (Biotita) } \\
& \text { (Clorita) }
\end{aligned}
$$




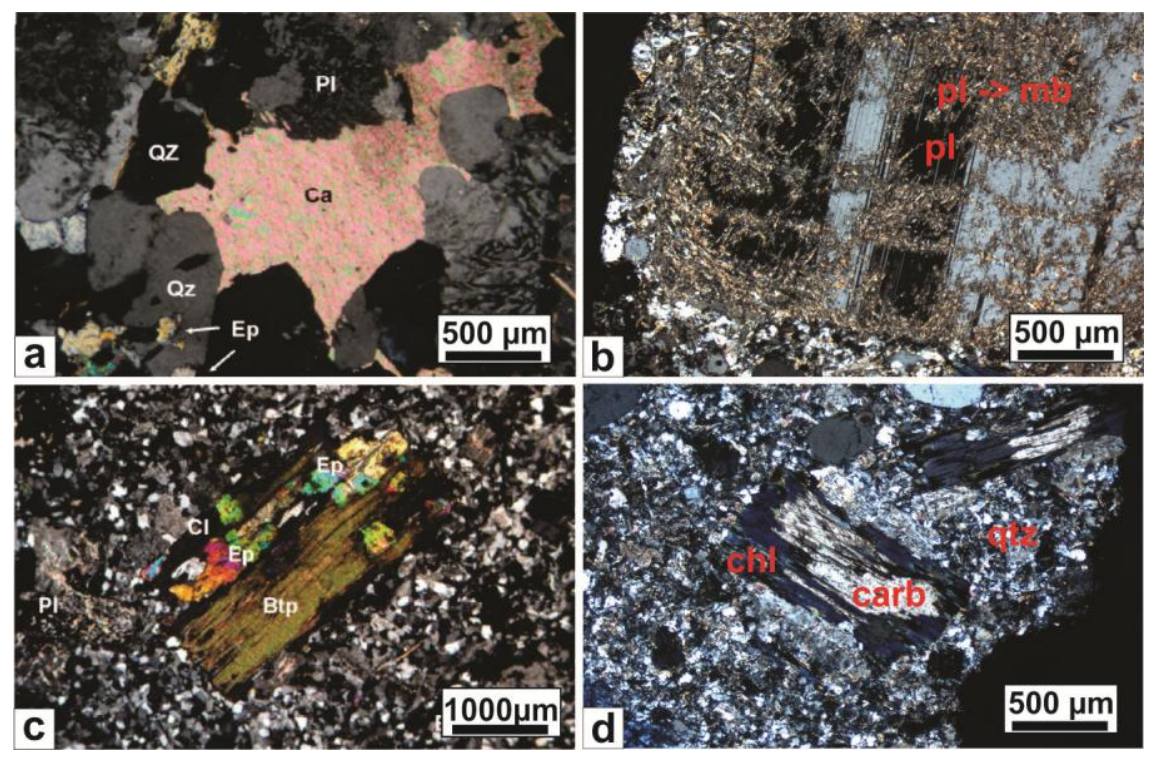

Figura 3.5- Nicóis paralelos: $\mathrm{N} / /$, nicóis cruzados: $\mathrm{NX}, \mathrm{Qz}=$ quartzo, $\mathrm{Ca}=$ carbonato, $\mathrm{Pl}=$ plagioclásio, $\mathrm{Mb}=$ mica branca, Btp = biotita primária, Ep = epidoto, Chl = clorita. a) 4x, NX. Formação de calcita e epidoto secundários na matriz dos diques afetados por alteração propilítica Martín (2007). b) 4x, NX. Parcial substituição de fenocristal de plagioclásio para mica branca nos diques afetados pela alteração propilítica, figura repetida da $2.8 \mathrm{~g}$. c) $2 \mathrm{x}$, NX. Fenocristal de biotita com parcial substituição para epidoto e clorita, característicos dos diques afetados por alteração propilítica, Martín (2007). d) 4x, NX. Detalhe de fenocristal de clorita com formação de carbonato em seu núcleo, figura repetida da $2.8 \mathrm{k}$.

Os resultados (Anexo 6) mostram que os cristais de clorita analisados possuem composição parecida, com valores de $\mathrm{Fe} /(\mathrm{Fe}+\mathrm{Mg})$ entre 0,42 e 0,54 e valores de $\mathrm{Al}^{\mathrm{IV}}$ entre 2 e 2,54 apfu, essa pequena variação sugere que houve equilíbrio entre os cristais de clorita e o fluido hidrotermal. Nos diagramas $\left(\mathrm{Al}^{\mathrm{iv}}\right.$ (apfu) $\times \mathrm{Fe} / \mathrm{Fe}+\mathrm{Mg}$ e $\mathrm{Mg}$ x $\mathrm{Fe}^{2+}+\mathrm{Fe}^{3+}$ ) observa-se que as cloritas das rochas com maior grau de alteração hidrotermal estão enriquecidas em Fe, o que pode indicar que durante o processo de alteração hidrotermal houve a troca catiônica de $\mathrm{Mg}$ por Fe (Figuras 3.6a e 3.6b).
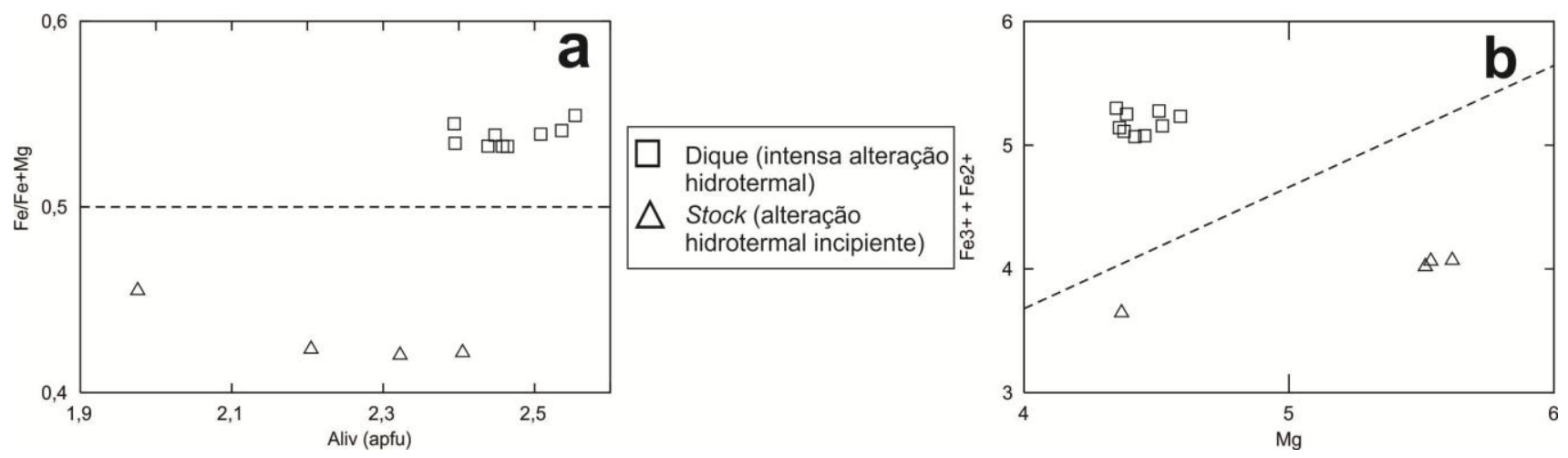

Figura 3.6- a) Diagrama $\mathrm{Al}^{\mathrm{iv}} \mathrm{x} \mathrm{Fe} / \mathrm{Fe}+\mathrm{Mg}$ que exibe enriquecimento em $\mathrm{Fe}$ das cloritas durante a alteração hidrotermal propilítica. b) Diagrama $\mathrm{Mg} \times \mathrm{Fe}^{3+}+\mathrm{Fe}^{2+}$ que exibe enriquecimento em $\mathrm{Fe}$ das cloritas durante a alteração hidrotermal propilítica. 
"O Sistema Magmático do Depósito de Cu-Mo Tipo Pórfiro Pancho Árias, Cordilheira Oriental, Argentina" Rafael Bellozupko Stremel

\subsection{Mineralização}

O sistema mineralizado do depósito Pancho Árias é do tipo disseminado ou incrustado nas rochas dos pórfiros andesíticos (Figura 3.7a), estendendo-se aos corpos de brecha (Figura 3.7b) e às rochas metassedimentares encaixantes. Porém nas encaixantes a mineralização é do tipo stockwork (Figuras 3.7c).
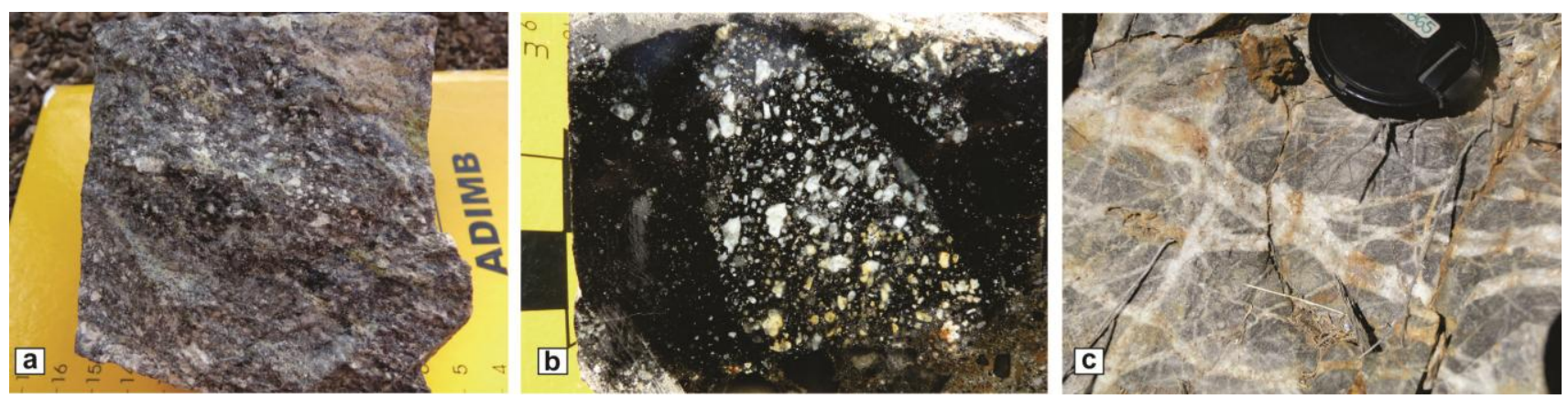

Figura 3.7- a) Textura disseminada e/ou incrustado dos sulfetos no pórfiro andesítico. b) Textura disseminada dos sulfetos no corpo de brecha B.n-01, sulfetos estão tanto na matriz como nos fragmentos. c) Mineralização venulada em arranjo stockwork das rochas encaixantes metassedimentares.

Nos pórfiros andesíticos e nos corpos de brecha, a mineralização é caracterizada por cristais anedrais a subedrais de pirita, com tamanho entre 0,5 e $2 \mathrm{~mm}$. Estes cristais possuem bordas corroídas, estão moderadamente fraturados e ocasionalmente apresentam microinclusões de calcopirita (Figura 3.8a). Além da pirita, os pórfiros possuem cristais anedrais a subedrais de calcopirita, com tamanho entre 0,2 e $0,5 \mathrm{~mm}$ com ocasionais desestabilização de borda para covelita (Figura 3.8b e 3.8d). Comumente há a formação de cristais de magnetita e ilmenita associados aos cristais de pirita. Nas rochas encaixantes a paragênese sulfetada é composta por cristais anedrais a subedrais de pirita, com tamanho entre 0,5 e $2 \mathrm{~mm}$ e por cristais anedrais de molibdenita, que ocorrem encapsulada nas venulações de quartzo desenhando arranjo stockwork (Figura 3.8e).

Em investigação por microssonda eletrônica, os cristais de calcopirita apresentam teores de $\mathrm{Cu}$ que variam entre 32 e $35 \%$ e de Fe entre $25 \%$ e $31 \%$, além de teores entre 0,03 e $0,2 \%$ de $\mathrm{Pb} . \mathrm{A}$ covelita, formada nas bordas dos grãos da calcopirita, possuí teores de $\mathrm{Cu}$ entre $68 \%$ e $76 \%$ e de $\mathrm{S}$ entre 17 e $23 \%$. Os cristais de pirita possuem teores entre 46 e $58 \%$ de Fe, além de teores entre 0,07 e $0,25 \%$ de $\mathrm{Pb}$ e teores de até $0,62 \%$ de $\mathrm{Ni}$. Os cristais de molibdenita apresentaram teores de aproximadamente 59\% em Mo, além de teor de até 0,3\% em Bi (Anexos 5, 9 e 10). Todas as fases minerais sulfetadas analisadas não possuem teores significativos em $\mathrm{Au}$ ou $\mathrm{Ag}$.

Os cristais de magnetita apresentaram teores em $\mathrm{FeO}_{\text {tot }}$ que variam entre $84 \%$ e 95\%, além de teores em F entre 0,18 e $0,35 \%, \mathrm{Al}_{2} \mathrm{O}_{3}$ entre 0,13 e 3,14\%, $\mathrm{K}_{2} \mathrm{O}$ entre 0,02 e $0,2 \%$ e $\mathrm{TiO}_{2}$ entre 0,02 e 
"O Sistema Magmático do Depósito de Cu-Mo Tipo Pórfiro Pancho Árias, Cordilheira Oriental, Argentina" Rafael Bellozupko Stremel

4,72\%. Os cristais de ilmenita revelaram teores em $\mathrm{TiO}_{2}$ que variam entre 75 e 99\%, além de teores de $\mathrm{Al}_{2} \mathrm{O}_{3}$ entre 0,01 e $0,7 \%, \mathrm{FeO}_{\text {tot }}$ entre 0,8 e $3 \%$ e $\mathrm{V}_{2} \mathrm{O}_{3}$ entre 0,4 e $1,2 \%$ (Anexo 11 ).

Em geoquímica de rocha total, as rochas do pórfiro com biotita possuem teores em $\mathrm{Cu}$ entre 83 e 5134 ppm, de Mo entre 120 e 772 ppm e de Au entre 13 e 23 ppb. As rochas pórfiro com hornblenda possuem teores de $\mathrm{Cu}$ entre 43 e 5344 ppm, Mo entre 45 e 421 ppm e Au entre 1 e 27 ppb. O stock quartzo monzodiorito e os diques possuem teores de $\mathrm{Cu}$ entre 193 e 205 ppm e 12 e 140 ppm, respectivamente. Ambas as fases não possuem teores significativos em Mo e Au.
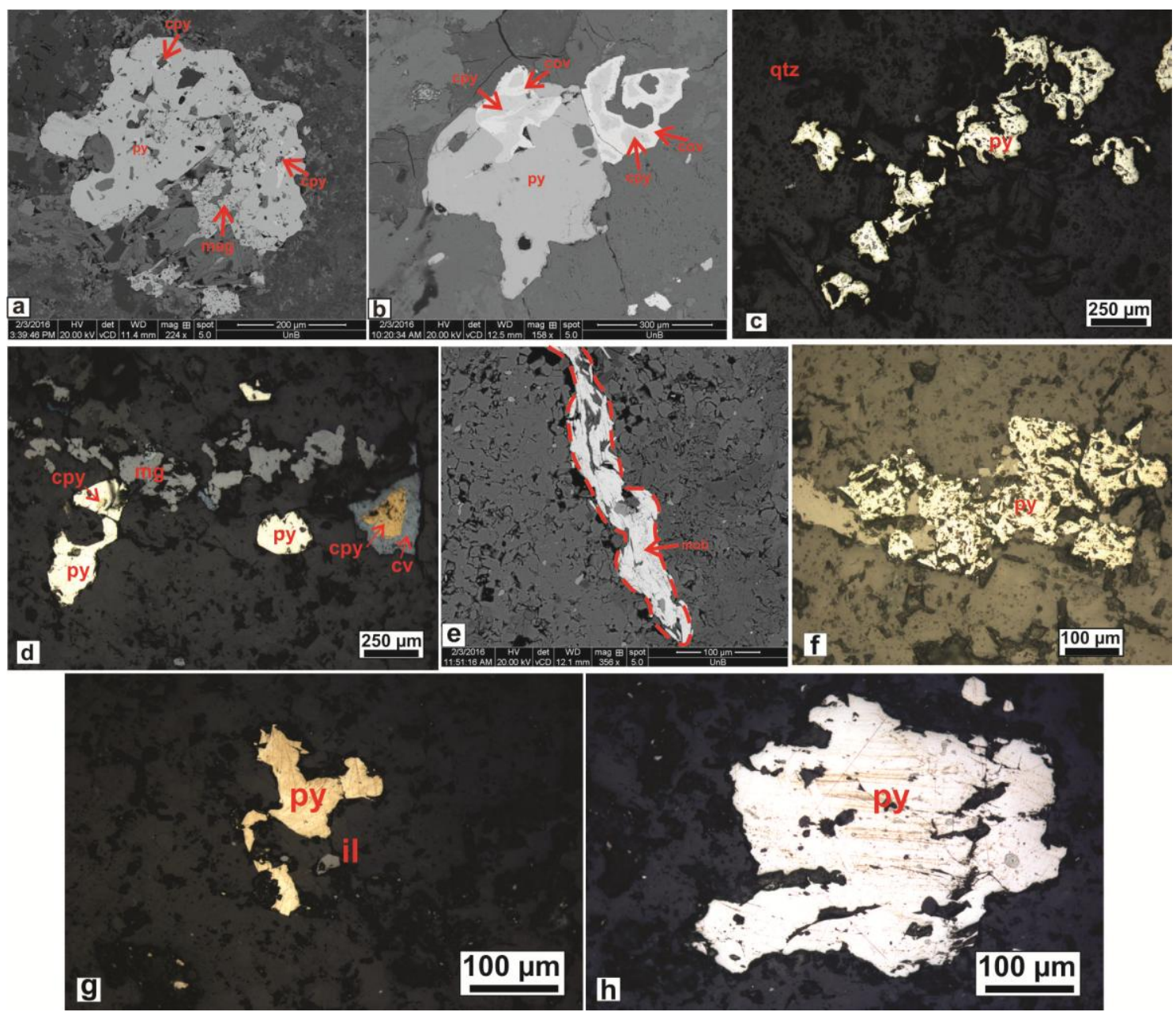

Figura 3.8- LR: luz refletida, $\mathrm{Cpy}=$ calcopirita, $\mathrm{Py}=$ pirita, $\mathrm{Mg}=$ magnetita, $\mathrm{Il}=$ ilmenita, $\mathrm{Mob}=$ molibdenita, $\mathrm{Cv}=$ covelita a) Imagem de elétrons retroespalhados em MEV de grão anedral de pirita com microinclusões de calcopirita e magnetita. b) Imagem de MEV de pirita e de calcopirita com alteração de borda para covelita. c) LR, 4X. Cristais anedrais de pirita, associados aos aglomerados de biotita hidrotermal formados na matriz da rocha. d) LR, 4X. Associação pirita/magnetita/calcopirita característica dos pórfiros andesíticos. e) Imagem de micro-vênula formada por grãos anedrais de molibdenita formado na rocha encaixante. f) LR, 2,5X. Cristal anedral de pirita presente no quartzomonzodiorito, destaca-se elevado grau de fraturamento e bordas corroídas. g) LR, 2,5X. Cristais anedrais de pirita e ilmenita presentes na matriz de dique. h) LR, 2,5X. Cristal subedral de pirita presente na matriz de dique, destaca-se moderado grau de fraturamento. 
"O Sistema Magmático do Depósito de Cu-Mo Tipo Pórfiro Pancho Árias, Cordilheira Oriental, Argentina"

Rafael Bellozupko Stremel

\subsection{Geocronologia}

Os estudos geocronológicos em isótopos radiogênicos (Ar-Ar, Sm-Nd e $\mathrm{Sr}-\mathrm{Sr}$ ) fornecem importantes informações sobre o processo de formação de rochas e minerais magmáticos, como idade de cristalização, fontes do magma e processos de fracionamento. Adicionalmente, estudos de Ar-Ar fornecem importantes informações em relação a atividade de alteração hidrotermal.

O estudo geocronológico no complexo magmático Las Burras-Almagro-El Toro sempre teve como foco principal as unidades vulcânicas Almagro e El Toro, sendo que os únicos dados obtidos no membro Las Burras são de 14,4 \0,3 Ma em datação U/Pb em zircões (Hongn et al., 2005), 13,10 $\pm 0,12$ Ma em datação Ar/Ar de Melik (1999), 14,2 \pm 0,04 (topo da intrusão) e 14,27 $\pm 0,04$ Ma (base da intrusão), ambos em isócrona de três pontos Rb-Sr, no monzodiorito Las Burras. Sillitoe (1977) obteve uma idade de $15,4 \pm 0,3 \mathrm{Ma}$ (K/Ar) em biotita hidrotermal no pórfiro do prospecto Pancho Árias (Tabela 3.1).

Tabela 3.1 - Síntese dos dados geocronológicos do complexo magmático Las Burras - Almagro - El Toro

\begin{tabular}{llllll}
\hline \hline & & & & & \\
Nome do Depósito/Membro/Formação & Rocha & Método & Mineral & Idade & Referência \\
\hline Pancho Árias & Dacito & K-Ar & Biotita Hidrotermal & $15,4 \pm 0,3$ & Sillitoe (1977) \\
Pancho Árias & Andesito & $\mathrm{Ar}-\mathrm{Ar}$ & Biotita Hidrotermal & $11,31 \pm 0,50$ & Esse estudo \\
Pancho Árias & Andesito & $\mathrm{Ar}-\mathrm{Ar}$ & Biotita Hidrotermal & $14,78 \pm 0,18$ & Esse estudo \\
Las Burras & Diorito & $\mathrm{U}-\mathrm{Pb}$ & Zircões & $14,4 \pm 0,3$ & Hongn et al. (1995) \\
Las Burras & Monzodiorito & $\mathrm{Ar}-\mathrm{Ar}$ & & $13,10 \pm 0,12$ & Melik (1999) \\
Las Burras & Monzodiorito & $\mathrm{Rb}-\mathrm{Sr}$ & Biotita/Plagioclásio & $14,2 \pm 0,04$ & Mazzuoli et al. (2005) \\
Las Burras & Monzodiorito & $\mathrm{Rb}-\mathrm{Sr}$ & Biotita/Plagioclásio & $14,27 \pm 0,04$ & Mazzuoli et al.(2006) \\
Inca Viejo & Andesito & $\mathrm{K}-\mathrm{Ar}$ & Biotita Magmática & $15,0 \pm 0,2$ & Sillitoe (1977) \\
\hline \hline
\end{tabular}

\subsubsection{Isótopos de $\mathrm{Sm} / \mathrm{Nd}$ e $\mathrm{Sr} / \mathrm{Sr}$}

Samário $(\mathrm{Sm})$ e neodímio $(\mathrm{Nd})$ são elementos terras raras leves, litófilos e formam íons com carga $3^{+}$. Cada elemento possui três isótopos, com o isótopo ${ }^{143} \mathrm{Nd}$ resultando da desintegração nuclear do isótopo ${ }^{147} \mathrm{Sm}$, através da emissão de uma partícula alfa. Suas concentrações em rochas ígneas crescem à medida que aumenta o grau de diferenciação das mesmas, pois, na maior parte dos casos, são considerados elementos incompatíveis. No entanto a razão $\mathrm{Sm} / \mathrm{Nd}$ decresce, já que o $\mathrm{Nd}$ é mais incompatível e se concentra mais no fluido magmático do que o Sm no processo de cristalização fracionada. Por terem comportamento geoquímico muito parecido, a razão $\mathrm{Sm} / \mathrm{Nd}$ permanece constante durante o processo de metamorfismo e alteração hidrotermal. 
"O Sistema Magmático do Depósito de Cu-Mo Tipo Pórfiro Pancho Árias, Cordilheira Oriental, Argentina" Rafael Bellozupko Stremel

O parâmetro $\varepsilon \mathrm{Nd}$ compara as razões ${ }^{143} \mathrm{Nd} /{ }^{144} \mathrm{Nd}$ atual ou da época da sua formação com as do CHUR. Se, à época da cristalização da rocha, o magma parental tiver razão ${ }^{143} \mathrm{Nd} /{ }^{144} \mathrm{Nd}$ mais elevada que o condrito, o $\varepsilon \mathrm{Nd}$ será positivo e a fonte seria o manto superior. Caso o magma parental tiver razão ${ }^{143} \mathrm{Nd} /{ }^{144} \mathrm{Nd}$ menor que a do condrito, o $\varepsilon \mathrm{Nd}$ será negativo e a fonte seria crustal.

Rubídio ( $\mathrm{Rb}$ ) e estrôncio ( $\mathrm{Sr}$ ) são elementos dos grupos IA e IIA respectivamente, ambos são litófilos e juntos possuem seis isótopos, dois do $\mathrm{Rb}$ e quatro do $\mathrm{Sr}$, com o isótopo ${ }^{87} \mathrm{Sr}$ sendo resultando da desintegração do ${ }^{87} \mathrm{Rb}$, através da emissão de uma partícula beta -.

Foram realizadas três análises de $\mathrm{Sm} / \mathrm{Nd}$ e $\mathrm{Sr} / \mathrm{Sr}$, duas são dos pórfiros andesíticos e outra é do stock quartzo monzodiorito, os resultados estão na Tabela 3.2.

Tabela 3.2 - Resultados das análises Sm-Nd e Rb-Sr

\begin{tabular}{|c|c|c|c|c|c|c|c|c|c|}
\hline $\begin{array}{c}\text { Fase } \\
\text { Magmática }\end{array}$ & Amostra & Sm(ppm) & Nd(ppm) & ${ }^{147} \mathrm{Sm} /{ }^{144} \mathrm{Nd}$ & $\begin{array}{c}{ }^{143} \mathrm{Nd} /{ }^{144} \mathrm{Nd} \\
\pm 2 \mathrm{SE}\end{array}$ & $\begin{array}{c}\varepsilon_{\mathrm{Nd}} \\
(0)\end{array}$ & $\begin{array}{c}\mathcal{E}_{N d} \\
(t)\end{array}$ & $\begin{array}{l}\mathbf{T}_{(\mathrm{DM})} \\
(\mathbf{G a})\end{array}$ & $\begin{array}{l}{ }^{87} \mathrm{Sr} /{ }^{86} \mathrm{Sr} \\
\pm 2 \mathrm{SE}\end{array}$ \\
\hline $\begin{array}{c}\text { Quartzo- } \\
\text { Monzodiorito }\end{array}$ & PA106 & 3,966 & 21,509 & 0,1115 & $0,512738 \pm 2$ & 1,95 & 2,11 & 0,62 & $0,70475 \pm 1$ \\
\hline PAA & $\begin{array}{c}\text { PA- } \\
\text { AND17 }\end{array}$ & 2,751 & 16,888 & 0,0985 & $0,512688 \pm 4$ & 0,97 & 1,17 & 0,61 & $0,70605 \pm 1$ \\
\hline PAB & $\begin{array}{c}\text { PA- } \\
\text { AND04 }\end{array}$ & 2,891 & 17,114 & 0,1021 & $0,512665 \pm 7$ & 0,52 & 0,71 & 0,66 & $0,70627 \pm 1$ \\
\hline
\end{tabular}

As rochas analisadas possuem valores semelhantes nos dados de Sm-Nd e Rb-Sr (Tabela 3.1). A idade modelo das três rochas é semelhante, sendo o pórfiro com biotita que possui a maior idade, de 0,66 Ga, e o outro pórfiro possui a menor idade, de 0,61 Ga. As idades-modelo $\mathrm{T}_{(\mathrm{DM})}$ e o $\varepsilon \mathrm{Nd}$ das três amostras foram calculadas com base no modelo do manto empobrecido, segundo os parâmetros estabelecidos por DePaolo (1981). Para os cálculos de $\varepsilon N d(t)$, foi utilizada a idade de 14,4 Ma para o stock quartzo-monzodiorito e de 15,4 Ma para os andesitos, e os valores são levemente positivos, variam de 0,71 a 2,12, sendo o maior valor correspondente ao quartzo-monzodiorito. As razões ${ }^{147} \mathrm{Sm} /{ }^{144} \mathrm{Nd}$ dos andesitos são 0,0985 e 0,1021 , enquanto a das rochas do stock monzodiorítico ${ }^{147} \mathrm{Sm} /{ }^{144} \mathrm{Nd}=0,1115$ e as razões ${ }^{143} \mathrm{Nd} /{ }^{144} \mathrm{Nd}$ para os andesitos e o monzodiorito são de 0,512688 , 0,512665 e 0,512738 , respectivamente. As razões ${ }^{87} \mathrm{Sr} /{ }^{86} \mathrm{Sr}$ são de 0,70627 e 0,70605 para os pórfiros, e 0,70475 para o stock. Estes valores são característicos de andesitos com alteração potássica, exibem assinatura isotópica com fracionamento dos isótopos de $\mathrm{Sm}-\mathrm{Nd}$, indicam baixo a moderado grau de contaminação crustal e exibem pequena variação no valor de $\varepsilon N d(t)$, o que pode caracterizar que o processo de contaminação crustal foi relativamente homogênio (Figura 3.9a). As razões Sr e Nd se assemelham com as razões de reservatório modelo de orógeno atual (Figura 3.9b). 
"O Sistema Magmático do Depósito de Cu-Mo Tipo Pórfiro Pancho Árias, Cordilheira Oriental, Argentina" Rafael Bellozupko Stremel
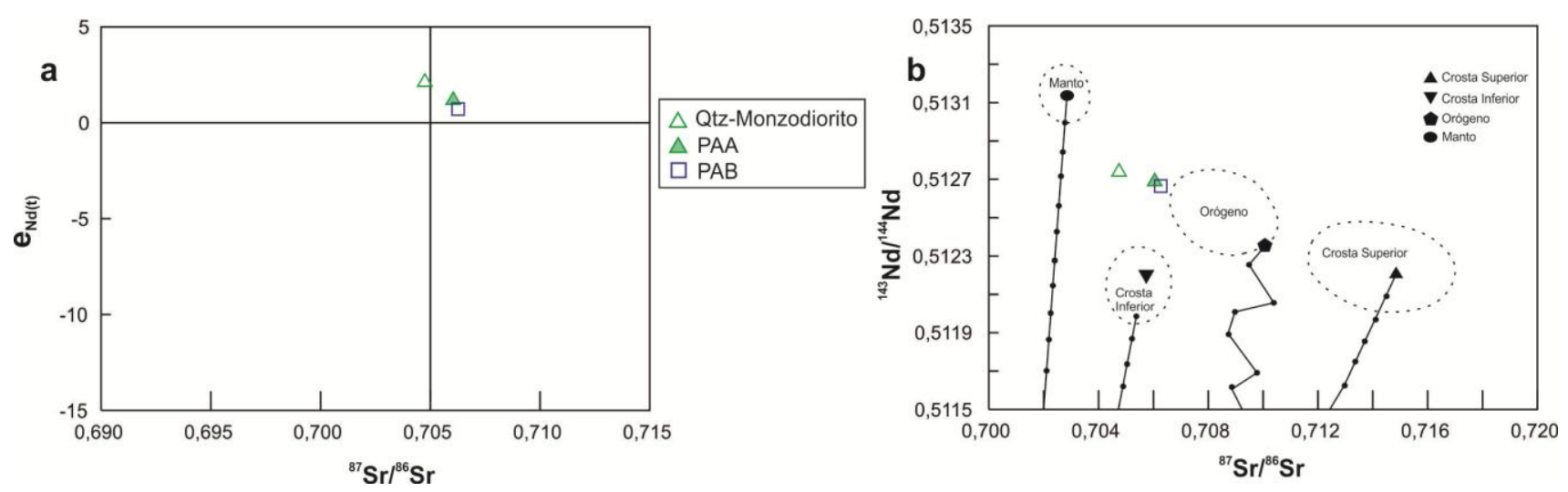

Figura 3.9- Diagrama ${ }^{87} \mathrm{Sr} /{ }^{86} \mathrm{Sr} x \in \mathrm{Nd}(\mathrm{t})$ com dados das rochas analisadas do depósitos Pancho Árias. Diagrama $\mathrm{Sr} \mathrm{x} \mathrm{Nd}$ comparando os dados deste estudo com as curvas de evolução isotópica de Sm e Nd para os reservatórios modelos com os campos contendo sua provável composição média atual. Pontos ao longo de cada curva indica incremento de tempo de 0,1 Ga. (Zartman \& Haines, 1988).

O diagrama $\varepsilon N d$ vs $\mathrm{T}(\mathrm{Ga})$ resume a evolução dos padrões de $\mathrm{Nd}$ para as rochas analisadas (Figura 3.10), indicando a existência de um único grupo de rochas e que as rochas das três fases magmáticas foram originadas a partir de fontes comuns.

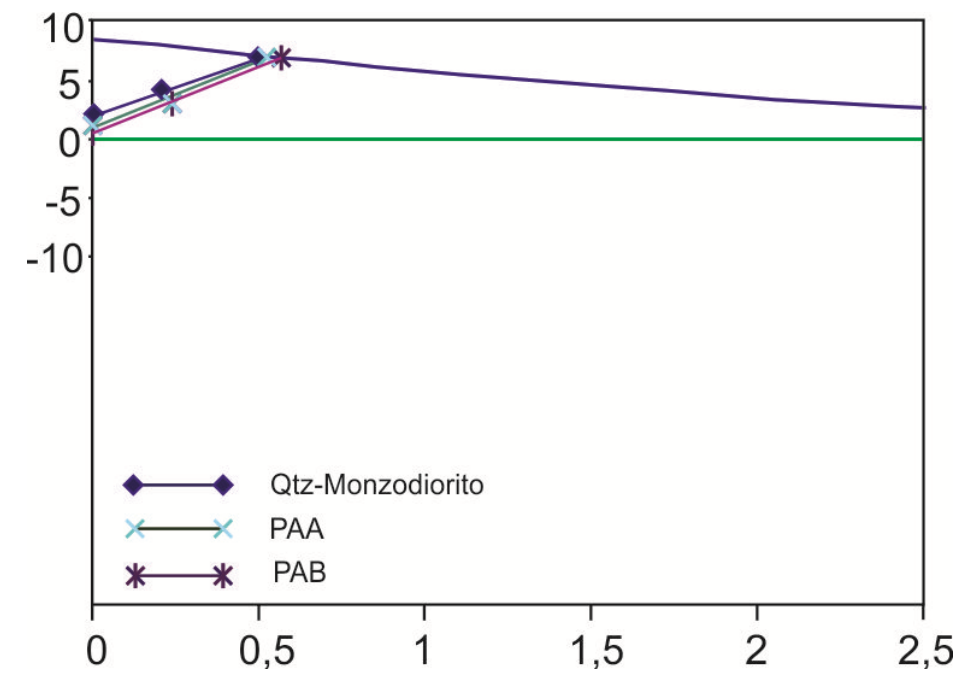

Figura 3.10 - Evolução isotópica Sm-Nd (idades e $\varepsilon N d$ ) para as rochas analisadas.

\subsubsection{Isótopos ${ }^{40} \mathrm{Ar} /{ }^{39} \mathrm{Ar}$}

Este método baseia-se na formação de ${ }^{39} \mathrm{Ar}$ pela irradiação de amostras contendo $\mathrm{K}$ em um reator nuclear de nêutrons rápidos. As determinações de ${ }^{40} \mathrm{Ar}-{ }^{39} \mathrm{Ar}$ são efetuadas dosando-se o ${ }^{40} \mathrm{Ar}$ radiogênico resultante da desintegração do ${ }^{40} \mathrm{~K}$ ao longo da vida da amostra. A determinação do ${ }^{40} \mathrm{~K}$ é obtida a partir da medida de ${ }^{39}$ Ar produzido artificialmente a partir do ${ }^{39} \mathrm{~K}$, uma vez que a relação ${ }^{40} \mathrm{~K} /{ }^{39} \mathrm{~K}$ é constante na natureza. 
"O Sistema Magmático do Depósito de Cu-Mo Tipo Pórfiro Pancho Árias, Cordilheira Oriental, Argentina" Rafael Bellozupko Stremel

As vantagens do método ${ }^{40} \mathrm{Ar}-{ }^{39} \mathrm{Ar}$ são: (1) a eliminação da necessidade de duas alíquotas para obtenção das abundâncias de ${ }^{40} \mathrm{~K}$ e de ${ }^{40} \mathrm{Ar}$ e (2) a possibilidade de se obter diversas idades em um grão de amostra a partir de frações de gás parcialmente liberadas no transcorrer da fusão por etapas. No método ${ }^{40} \mathrm{Ar}-{ }^{39} \mathrm{Ar}$ de fusão por etapas uma série de idades de uma única amostra pode ser obtida através do aumento gradual da temperatura. O Ar liberado em cada etapa é recolhido, purificado e analisado no espectômetro de massa.

$\mathrm{O}$ emprego do método ${ }^{40} \mathrm{Ar}-{ }^{39} \mathrm{Ar}$ têm se tornado uma excelente ferramenta para melhor compreensão dos processos hidrotermais tardi-magmáticos. Como os andesitos porfiríticos do depósito Pancho Árias estão inseridos no contexto da Cordilheira Oriental dos Andes Centrais, esse método se torna uma importante ferramenta para se determinar a idade de resfriamento do sistema hidrotermal e sua relação temporal com o evento magmático.

Para a obtenção da idade, pelo método ${ }^{40} \mathrm{Ar}-{ }^{39} \mathrm{Ar}$, do processo hidrotermal tardi-magmático do depósito Pancho Árias, utilizaram-se biotitas de alteração hidrotermal presentes nos andesitos. As Tabelas 3.3 e 3.4 sintetizam os dados analíticos ${ }^{40} \mathrm{Ar}-{ }^{39} \mathrm{Ar}$ para as rochas analisadas.

Tabela 3.3 - Dados analíticos ${ }^{40} \mathrm{Ar}-{ }^{39} \mathrm{Ar}$ da amostra PA 102

\begin{tabular}{|c|c|c|c|c|c|c|c|c|c|c|c|c|}
\hline $\begin{array}{c}\text { Power } \\
(\%)\end{array}$ & $36 \mathrm{Ar} / 40 \mathrm{Ar}$ & $\pm(1 \mathrm{~s})$ & 39Ar/40Ar & $\pm(1 \mathrm{~s})$ & $\mathbf{r}$ & $\mathrm{Ca} / \mathrm{K}$ & $\pm(1 \mathrm{~s})$ & $\mathrm{Cl} / \mathrm{K}$ & $\begin{array}{c}\text { 40Ar* } \\
(\%)\end{array}$ & $\begin{array}{l}\text { Fraction } \\
\text { 39Ar (\%) }\end{array}$ & 40Ar*/39Ar & $\begin{array}{l}\text { Age } \\
\text { (Ma) }\end{array}$ \\
\hline 4,5 & 0,002730 & 0,000083 & 0,061476 & 0,000437 & 0,015720 & 0,03 & 0,01 & 0,0210 & 19,3 & 18,89 & 3,142 & 6,76 \\
\hline 5,5 & 0,002533 & 0,000046 & 0,055327 & 0,000253 & 0,025199 & 0,03 & 0,01 & 0,0227 & 25,1 & 16,43 & 4,544 & 9,77 \\
\hline 6,5 & 0,002435 & 0,000047 & 0,054646 & 0,000332 & 0,018570 & 0,03 & 0,01 & 0,0235 & 28,0 & 11,04 & 5,135 & 11,04 \\
\hline 7,5 & 0,002416 & 0,000056 & 0,052474 & 0,000334 & 0,018479 & 0,03 & 0,01 & 0,0238 & 28,6 & 8,65 & 5,452 & 11,72 \\
\hline 8,5 & 0,002354 & 0,000055 & 0,053275 & 0,000345 & 0,011763 & 0,03 & 0,01 & 0,0244 & 30,4 & 8,96 & 5,715 & 12,28 \\
\hline 9,5 & 0,002460 & 0,000080 & 0,053108 & 0,000519 & 0,011101 & 0,02 & 0,02 & 0,0242 & 27,3 & 5,09 & 5,140 & 11,05 \\
\hline 11,0 & 0,002421 & 0,000105 & 0,052935 & 0,000446 & 0,011375 & 0,01 & 0,02 & 0,0231 & 28,4 & 4,06 & 5,375 & 11,55 \\
\hline 13,5 & 0,002436 & 0,000087 & 0,054130 & 0,000456 & 0,011041 & 0,03 & 0,01 & 0,0217 & 28,0 & 4,53 & 5,176 & 11,12 \\
\hline 18,0 & 0,002440 & 0,000079 & 0,054040 & 0,000441 & 0,021062 & 0,02 & 0,01 & 0,0228 & 27,8 & 5,22 & 5,161 & 11,09 \\
\hline 25,0 & 0,002478 & 0,000079 & 0,053973 & 0,000401 & 0,017443 & 0,02 & 0,02 & 0,0216 & 26,7 & 5,70 & 4,961 & 10,66 \\
\hline 45,0 & 0,002374 & 0,000049 & 0,058027 & 0,000357 & 0,014153 & 0,06 & 0,01 & 0,0239 & 29,8 & 11,42 & 5,142 & 11,05 \\
\hline
\end{tabular}


"O Sistema Magmático do Depósito de Cu-Mo Tipo Pórfiro Pancho Árias, Cordilheira Oriental, Argentina"

Rafael Bellozupko Stremel

Tabela 3.4 - Dados analíticos ${ }^{40} \mathrm{Ar}-{ }^{39} \mathrm{Ar}$ da amostra PA 103

\begin{tabular}{|c|c|c|c|c|c|c|c|c|c|c|c|}
\hline $\begin{array}{c}\text { Power } \\
(\%)\end{array}$ & 36Ar/40Ar & $\pm(1 \mathrm{~s})$ & 39Ar/40Ar & $\pm(1 \mathrm{~s})$ & $\mathbf{r}$ & $\mathrm{Cl} / \mathrm{K}$ & $\pm(1 \mathrm{~s})$ & $\begin{array}{c}\text { 40Ar* } \\
(\%)\end{array}$ & $\begin{array}{l}\text { Fraction } \\
\text { 39Ar (\%) }\end{array}$ & 40Ar*/39Ar(K) & $\begin{array}{l}\text { Age } \\
\text { (Ma) }\end{array}$ \\
\hline 2,5 & 0,003500 & 0,000623 & 0,006749 & 0,000883 & 0,006519 & 0,0481 & 0,03 & 0,0 & 0,00 & 0,000 & 0,00 \\
\hline 3,2 & 0,003175 & 0,000218 & 0,007324 & 0,000308 & 0,006862 & 0,0209 & 0,01 & 6,2 & 0,00 & 8,444 & 18,11 \\
\hline 3,9 & 0,003177 & 0,000158 & 0,012020 & 0,000354 & 0,007729 & 0,0196 & 0,00 & 6,1 & 0,00 & 5,084 & 10,93 \\
\hline 4,5 & 0,002964 & 0,000129 & 0,020600 & 0,000378 & 0,014344 & 0,0241 & 0,00 & 12,4 & 0,00 & 6,028 & 12,95 \\
\hline 5,5 & 0,002663 & 0,000109 & 0,034220 & 0,000377 & 0,011829 & 0,0243 & 0,00 & 21,3 & 0,00 & 6,224 & 13,37 \\
\hline 6,5 & 0,002244 & 0,000077 & 0,050635 & 0,000430 & 0,014448 & 0,0272 & 0,00 & 33,6 & 0,00 & 6,653 & 14,29 \\
\hline 8,0 & 0,001660 & 0,000064 & 0,073524 & 0,000433 & 0,013801 & 0,0284 & 0,00 & 50,8 & 0,00 & 6,931 & 14,88 \\
\hline 9,5 & 0,001599 & 0,000058 & 0,075735 & 0,000461 & 0,012717 & 0,0281 & 0,00 & 52,6 & 0,00 & 6,966 & 14,96 \\
\hline 11,0 & 0,001693 & 0,000080 & 0,073537 & 0,000438 & 0,008338 & 0,0276 & 0,00 & 49,9 & 0,00 & 6,797 & 14,59 \\
\hline 15,0 & 0,001458 & 0,000070 & 0,082681 & 0,000634 & 0,013168 & 0,0274 & 0,00 & 56,8 & 0,00 & 6,885 & 14,78 \\
\hline 22,0 & 0,001028 & 0,000045 & 0,101275 & 0,000490 & 0,010324 & 0,0278 & 0,00 & 69,4 & 0,00 & 6,873 & 14,76 \\
\hline 27,0 & 0,000639 & 0,000034 & 0,117668 & 0,000566 & 0,010043 & 0,0288 & 0,00 & 80,8 & 0,00 & 6,893 & 14,80 \\
\hline 33,0 & 0,000458 & 0,000031 & 0,125829 & 0,000462 & 0,006482 & 0,0290 & 0,00 & 86,1 & 0,00 & 6,872 & 14,76 \\
\hline 45,0 & 0,000428 & 0,000033 & 0,126597 & 0,000549 & 0,008106 & 0,0283 & 0,00 & 87,0 & 0,00 & 6,899 & 14,81 \\
\hline
\end{tabular}

Os resultados obtidos revelaram um espectro de idades ${ }^{40} \mathrm{Ar}-{ }^{39} \mathrm{Ar}$ marcados por idades platô de $11 \pm 0,5 \mathrm{Ma}$ (Figuras 3.10a e 3.11a) e $15 \pm 0,2 \mathrm{Ma}$, com MSWD de 0,46 e 0,12. A relação nas razões $\mathrm{Ca} / \mathrm{K}$ e $\mathrm{Cl} / \mathrm{K}\left({ }^{39} \mathrm{Ar}\right.$ ) (Figuras 3.11 b 3.11c 3.13b e 3.12c) revelam uma composição bastante homogênea, sem significativa contribuição de argônio nos produtos alterados e/ou modificados por distúrbios termais posteriores sugerindo que a idade de fechamento obtida está relacionada ao fechamento do processo hidrotermal sin a tardi magmático responsável pela formação da mineralização.
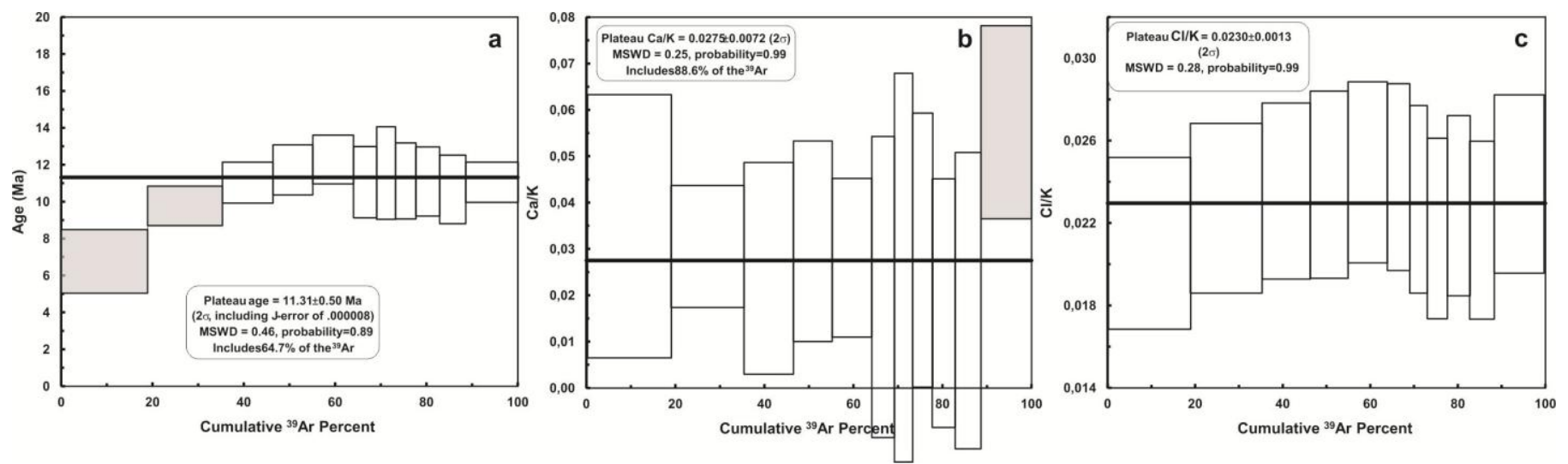

Figura 3. 11- Resultados da análise da biotita da amostra PA 102 a) Idades platô ${ }^{40} \mathrm{Ar} /{ }^{39} \mathrm{Ar}$; B) relações Ca/K aplicadas ao cálculo da Idade Ar-Ar. c) relações $\mathrm{Cl} / \mathrm{K}$ aplicadas ao cálculo da Idade Ar-Ar. 
"O Sistema Magmático do Depósito de Cu-Mo Tipo Pórfiro Pancho Árias, Cordilheira Oriental, Argentina"
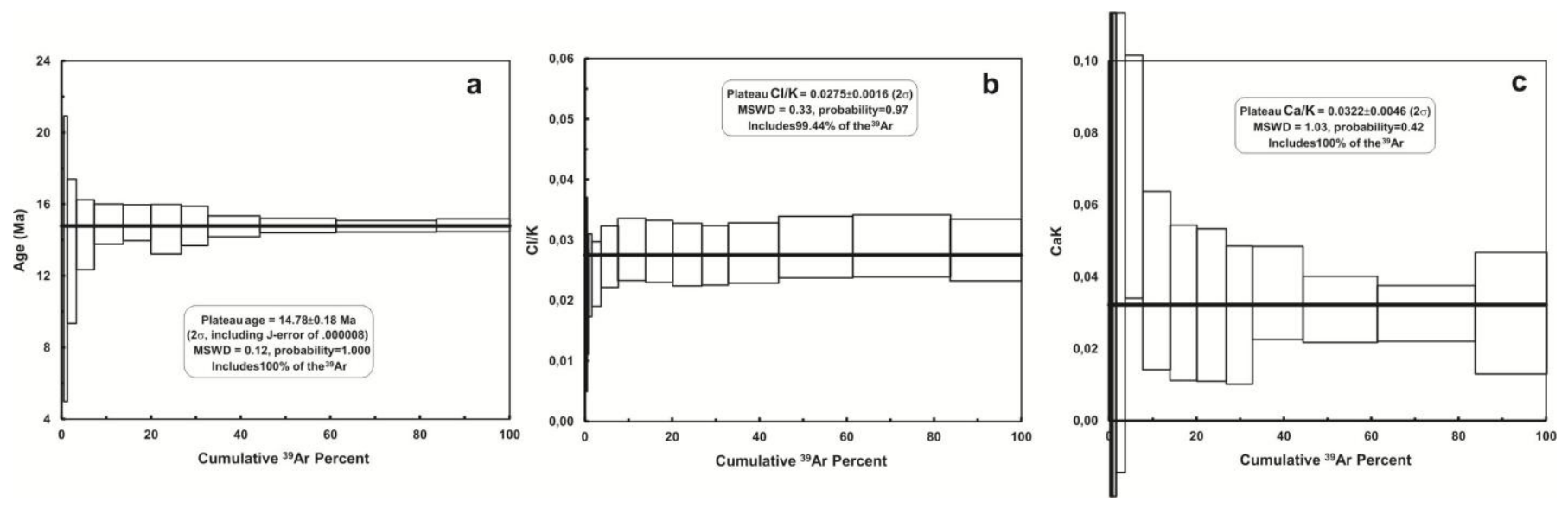

Figura 3. 12- Resultados da análise da biotita da amostra PA 103 a) Idades platô ${ }^{40} \mathrm{Ar} /{ }^{39} \mathrm{Ar}$; B) relações $\mathrm{Ca} / \mathrm{K}$ aplicadas ao cálculo da Idade Ar-Ar. c) relações $\mathrm{Cl} / \mathrm{K}$ aplicadas ao cálculo da Idade Ar-Ar.

\subsection{Discussão}

As características de campo, análises petrográficas e de dados de química mineral indicam que o sistema de alteração hidrotermal registrado na área em estudo não possui controle litológico e é essencialmente controlado pelas propriedades térmicas e químicas dos fluidos responsáveis por ela.

As zonações temporais e espaciais da alteração e mineralização associadas a depósitos de $\mathrm{Cu}$ pórfiro são atribuídas a uma mudança de um sistema hidrotermal dominado por fluídos magmáticos para um dominado por fluidos meteóricos (Gustafson \& Hunt,. 1975; Beane \& Titley, 1981; Reynolds \& Beane, 1985). A interação desses dois fluidos distintos provavelmente é a causa da mineralização em $\mathrm{Cu}-\mathrm{Mo}$, em resposta à diminuição da temperatura $\left(<350^{\circ} \mathrm{C}\right)$ e outros parametros físico-químicos (salinidade, pH, Eh e na fugacidade oxigénio e enxofre).

Lowell \& Guilbert (1970), propuseram um modelo que caracteriza a assembléia mineral do sistema de zonação da alteração hidrotermal concêntrica em sistemas de $\mathrm{Cu}$-Mo pórfiros. $\mathrm{O}$ centro é caracterizado por um núcleo com predomínio de quartzo, sericita e feldspato potássico, esse núcleo é circundado por uma zona potássica, representado por quartzo, feldspato potássico, biotita e sericita, a terceira zona é a sericítica, caracterizada por quartzo, sericita e pirita, a última zona é a propilítica, marcada por clorita, epidoto e carbonato.

A alteração potássica inicial, de média a alta temperatura $\left(350^{\circ}\right.$ a $\left.800^{\circ}\right)$ tende a ocorrer em profundidade crustal de aproximadamente $2 \mathrm{~km}$ e caracteriza-se por uma alteração altamente penetrativa que comumente geram estruturas do tipo stockwork, observada nas rochas encaixantes da Formação Puncoviscana. Esse processo é caracterizado pela geração de densa venulação em quartzo 
"O Sistema Magmático do Depósito de Cu-Mo Tipo Pórfiro Pancho Árias, Cordilheira Oriental, Argentina" Rafael Bellozupko Stremel

e pela geração de biotita de alteração com similar composição das biotitas magmáticas (exemplificados na figura 3.3). Substituição metassomática de magnésio-hornblenda e biotita primárias em condições de $\mathrm{pH}$ neutro a alcalino também são característicos da zona de alteração hidrotermal potássica, como foram descritos nos pórfiros andesíticos, através da substituição de fenocristais e formação de aglomerados de biotita na matriz (Corbett \& Leach, 1998). Somado a isso, a temperatura de homogeneização em inclusões fluidas, obtidas para a zona potássica são de 511$540^{\circ} \mathrm{C}$, com concentração de sais de $61,3-65,3 \% \mathrm{NaCl}$ eq (JICA, 2002), esse dado confirma que a associação de alteração potássica do prospecto Pancho Arias foi efetivamente efeito da circulação de fluidos altamente salinos e quentes, típicos de ambiente pórfiro (Sillitoe, 1985; Corbett \& Leach, 1998, Martín 2007).

A associação clorita-epidoto-calcita é observada nos diques e nas rochas encaixantes que localizam-se nas porções externas da área, essa associação mineral é característica das zonas de alteração propilítica proposta por Lowell \& Guilbert (1970) . Esse tipo de alteração ocorre como um halo gradacional e distal da zona de alteração potássica, o que caracteriza um gradiente termal decrescente desde o núcleo (Figura 3.13). Esse tipo de alteração se forma em condições de pH neutro a alcalino e mais baixas temperaturas, entre $150^{\circ}$ e $250^{\circ} \mathrm{C}$ (Corbett \& Leach, 1998).

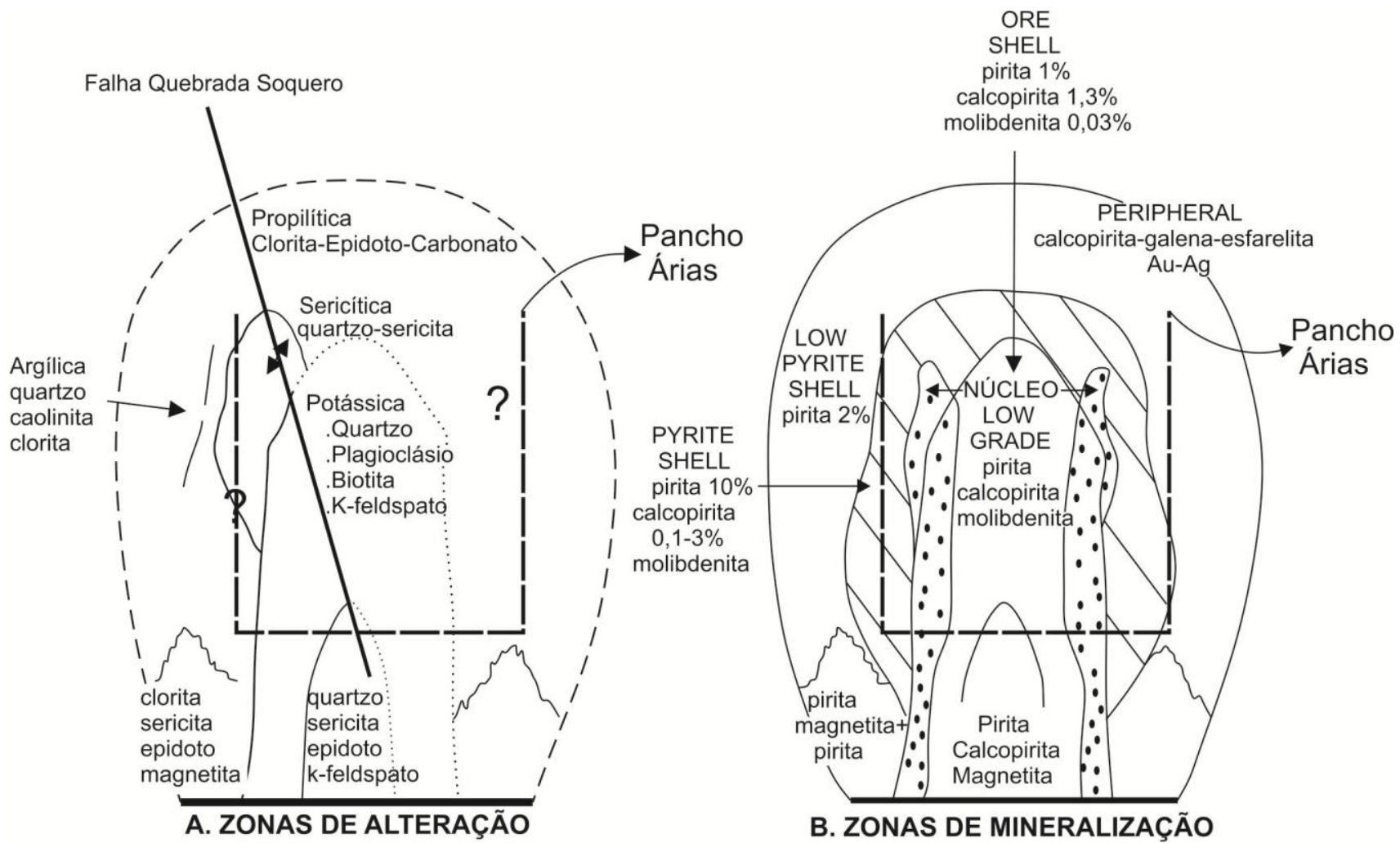

Figura 3.13- Modelos de zonas de alteração hidrotermal e zonas de mineralização em depósitos de Cu do tipo pórfiro destaca-se colocação do depósito Pancho Árias. Proposto por Lowell \& Guilbert (1970). 
"O Sistema Magmático do Depósito de Cu-Mo Tipo Pórfiro Pancho Árias, Cordilheira Oriental, Argentina" Rafael Bellozupko Stremel

A alteração sericítica comumente revela uma progressiva diminuição no $\mathrm{pH}$ dos fluidos e tende a se sobrepor a outros tipos de alteração. Esse processo ocorre nos últimos estágios do processo de alteração com participação de águas meteóricas. Na área em estudo, zona de alteração fílica que se desenvolve nas imediações da falha NW-SE, localizada no local denominado de Quebrada de Soquero, além de sobrepor a zona de alteração potássica, esses fatores caracterizam essa zona de alteração como a única com algum controle estrutural e também como um evento de alteração tardio em relação aos demais registrados na área.

Os sulfetos também possuem distribuição zonada em depósitos do tipo Cu-Mo pórfiros, com a zona do minério sendo representada por assembleia mineral composta por pirita, calcopirita, molibdenita e magnetita. Essa zona mineralizada localiza-se na zona de alteração hidrotermal potássica até perto do contato com a zona de alteração fílica. A calcopirita comumente é associada aos minerais calcissilicáticos e sua formação é diretamente ligada a formação do microclínio metassomático que se desenvolve substituindo os fenocristais de plagioclásio, visto que essa formação de feldspato potássico em plagioclásios envolve expansão volumétrica suficiente para a geração de fraturas que abrem o sistema para o fluxo de fluidos responsáveis pela deposição dos metais (Xu et al., 2004). A zona da pirita é caracterizada por grande predomínio de pirita em relação a calcopirita e tende a ocorrer associada a zona fílica. A porção externa, correspondente a zona de alteração propilítica é caracterizada por baixos teores de sulfeto, os quais são caracterizados por pirita e calcopirita.

Comparativamente aos dados de $\varepsilon \mathrm{Nd}(\mathrm{t}), \mathrm{T}_{(\mathrm{DM})},{ }^{147} \mathrm{Sm} /{ }^{144} \mathrm{Nd},{ }^{143} \mathrm{Nd} /{ }^{144} \mathrm{Nd}$ e ${ }^{87} \mathrm{Sr} /{ }^{86} \mathrm{Sr}$ obtidos por Borba et al.(2016), nota-se que as três rochas analisadas possuem semelhanças ao grupo cuja assinatura isotópica indica fracionamento dos isótopos de $\mathrm{Sm}-\mathrm{Nd}$ e com baixo a moderado grau de contaminação crustal, além de derivarem de mesma fonte magmática (Figura 3.10). Segundo Mazzuoli et al. (2008), o processo de fusão parcial do manto litosférico empobrecido gerou os magmas formadores da unidade regional Las Burras, cuja baixa razão isotópica do Sr e elevada do Nd sugerem um moderado envolvimento do embasamento Paleozoico durante a ascensão do magma, com cristalização fracionada e baixa contaminação crustal.

Os resultados obtidos pelo método ${ }^{40} \mathrm{Ar}-{ }^{39} \mathrm{Ar}$ sugerem que o processo de alteração hidrotermal potássica ocorreu de 14,8 a $11 \mathrm{Ma}$, valores concordantes com a idade de 15,4 Ma (K/Ar) de Sillitoe (1977) e que corroboram que o Pancho Árias é o corpo mais velho do membro Las

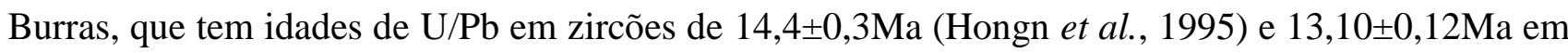
datação Ar/Ar de Melik (1999), ambos no monzodiorito Las Burras. 
"O Sistema Magmático do Depósito de Cu-Mo Tipo Pórfiro Pancho Árias, Cordilheira Oriental, Argentina"

Rafael Bellozupko Stremel

\section{CAPÍTULO 4}

\subsection{Modelo de Evolução Magmática}

A mineralização em $\mathrm{Cu}$ pórfiro nos Andes argentinos ocorreu em dois principais intervalos de tempo, sendo uma no Carbonífero - Permiano e outra no Mioceno (Sillitoe, 1977). O depósito de CuMo tipo pórfiro Pancho Árias está associado ao magmatismo do Mioceno, o qual se desenvolveu ao longo no sistema de falhas NW-SE denominado Calama - Olacapato - El toro e provavelmente foi controlado pela maior inclinação do antigo flat slab da placa continental (Isacks, 1988; Kay et al., 1999; Kay \& Mpodozis, 2001).

Através de uma análise comparativa entre os dados aqui apresentados e aqueles disponíveis na literatura, pode-se dividir a evolução magmática e metalogenética do depósito Pancho Árias em seis fases distintas, as quais são descritas a seguir.

\subsubsection{Estágio I - Geração e Alojamento dos Magmas}

Em arcos compressionais, intrusões de magmas comumente são alojadas em porções crustais rasas durante um evento de relaxamento da compressão, gerando local extensão. $\mathrm{Na}$ área de estudo, o alojamento do melt em níveis crustais foi controlado pela reativação do sistema de falhas do tipo strike-slip, com direção N-S, o qual se desenvolveu em contexto tectônico de convergência oblíqua (Acocella et al., 2007; Mazzuoli et al., 2008).

Os membros magmáticos andesíticos foram formados a partir de diferentes pulsos magmáticos gerados a partir de um melt comum, provavelmente de composição granodiorítica, gerado através da fusão parcial do manto litosférico, resultado do amalgamento da litosfera, em aproximadamente 15 Ma (Mazzuoli et al., 2008). A assinatura geoquímica e isotópica das fases magmáticas em estudo indica derivação mantélica e interação com a crosta durante o processo de ascensão e cristalização fracionada, em contexto tectônico de arco (Figura 4.1A). As relações intrusivas e texturais permitem interpretar que o pórfiro andesítico com anfibólio alojou-se posteriorimente em relação ao pórfiro andesítico com biotita, quando esta ainda estava em condições plásticas (Figura 4.1B e 4.1C).

Segundo Xu et al. (2012), a cristalização fracionada, acumulação e concentração de silicatos do melt na câmara magmática, gera um processo de enriquecimento em voláteis e metais, tais como como $\mathrm{Au}, \mathrm{Cu}$, e Mo. Elementos incompatíveis formadores de mineralizações (como o Mo), fundidos 
"O Sistema Magmático do Depósito de Cu-Mo Tipo Pórfiro Pancho Árias, Cordilheira Oriental, Argentina" Rafael Bellozupko Stremel

sulfetados, líquidos residuais e vapores são diretamente concentrados no magma durante a cristalização dos silicatos. Por outro lado, elementos compatíveis afins ao $\mathrm{Cu}$ podem ser concentrados no magma pelo particionamento de líquidos sulfetados e/ou fluidos residuais ricos em sulfatos e cloretos. Pulsos subsequentes de novos melts para dentro da câmara magmática enquanto silicatos já cristalizados são removidos do melt, podem gerar gradualmente concentrações em metais bases, produzindo pequenas concentrações de melts ricos em metais. Esses magmas pórfiros ricos em metais são alojados em níveis crustais rasos e contém alguns fenocristais e agregados glomeroporfiríticos. Tais características evolutivas são também discutidas por vários outros autores (ver, por exemplo, Candela \& Holland, 1986; Hedenquist \& Lowenstern, 1994, Richards, 2003; Mustard et al., 2006).

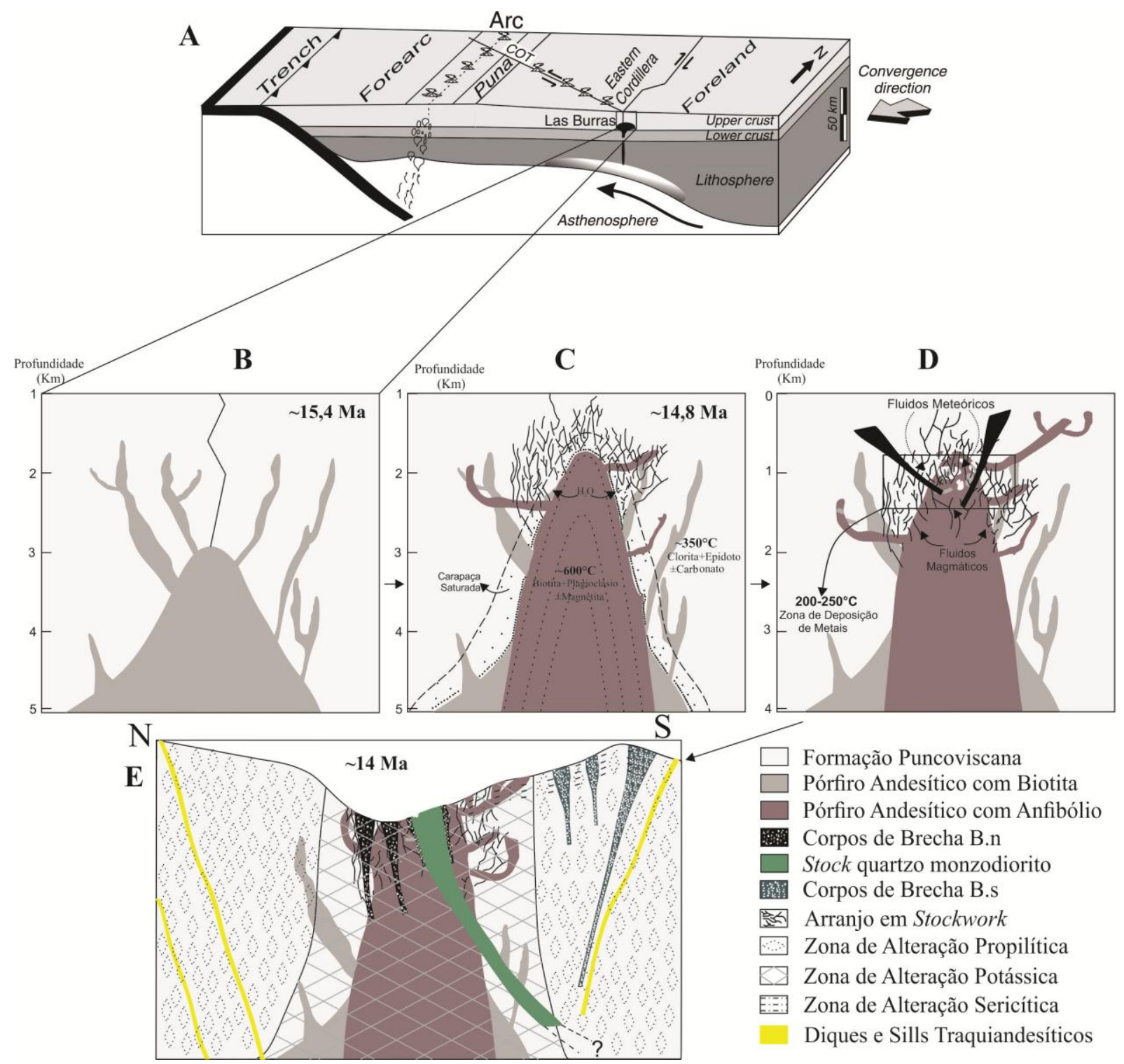

Figura 4.1- Evolução geológica do depósito Pancho Árias. 
"O Sistema Magmático do Depósito de Cu-Mo Tipo Pórfiro Pancho Árias, Cordilheira Oriental, Argentina" Rafael Bellozupko Stremel

4.1.2 Estágio II - Alteração hidrotermal dos tipos potássica e propilítica com zonação do tipo concêntrica e primeira formação de metais

A colocação dos melts em níveis crustais mais rasos gerou resfriamento e consequente processo de cristalização, os quais foram acompanhados pela formação de assembleias de alteração hidrotermal zonadas, em resposta à transferência de calor do melt para as rochas encaixantes (McMillan \& Panteleyev, 1988). No depósito Pancho Árias, essa alteração zonada varia progressivamente de uma zona de alteração potássica central, gerada a partir de 15 Ma, para uma assembleia de alteração propilítica, característica de menores temperaturas (Figura 4.1C).

As reações metassomáticas de alteração potássica, exemplificadas no capítulo 3, ocorrem em nas fases iniciais de cristalização, a temperaturas de $400-700^{\circ} \mathrm{C}$ e profundidade crustal de aproximadamente $2 \mathrm{~km}$. Essas reações metassomáticas formaram no depósito em estudo uma assembleia mineral de alteração composta predominantemente por biotita, mineral de alteração mais comum em condições cálcio-alcalinas (Burnham, 1979; Sheppard et al., 1971; Ford \& Green, 1977). A parcial substituição dos fenocristais de hornblenda para biotita ocorre a partir de fluidos magmáticos e podem ter se formado em resposta a reação entre o melt e os fenocristais primários. Subordinado à biotita, há a formação de cristais de quartzo, plagioclásio e magnetita secundários, que podem ser interpretados como reflexo de condições relativamente oxidantes, neutras a alcalinas (Corbett \& Leach, 1998). Relacionado ao processo de alteração potássica ocorre a primeira fase de deposição de metais, os quais ocorrem sob a forma de pirita e calcopirita em fissuras e cavidades.

Nas porções externas, a principal assembleia de alteração observada é composta pela associação epidoto-clorita-carbonato (Figura 3.5a), a qual caracteriza uma típica zona de alteração propilítica distal em relação ao núcleo potássico, refletindo assim condições progressivamente mais frias, resultado da troca de calor com as rochas encaixantes (temperatura entre 200 e $350^{\circ} \mathrm{C}$, segundo Corbett \& Leach ,1998). A associação clorita-epidoto em condições cálcio-alcalinas observada na área (Figura 3.5c) tende a ocorrer nas bordas da zona potássica e no interior das zonas propilíticas. Embora a magnetita seja abundante na zona propilítica, a pirita é a fase metálica dominante nessas condições de baixa temperatura, pouco oxidantes e com baixo pH (Figura 4.1C).Tais feições também foram descritas em outros depósitos (ver Sillitoe \& Gappe, 1984; Kosaka \& Wakita, 1978; MacDonald \& Arnold, 1994). 
"O Sistema Magmático do Depósito de Cu-Mo Tipo Pórfiro Pancho Árias, Cordilheira Oriental, Argentina" Rafael Bellozupko Stremel

\subsubsection{Estágio III - Geração dos Veios de Quartzo em Estruturas Stockwork}

Concomitantemente ao segundo estágio, o resfriamento, cristalização do melt e exsolução das fases voláteis foram os principais responsáveis pelo fraturamento das rochas, especialmente em torno da carapaça da intrusão. Esse fenômeno provavelmente ocorreu quando a pressão dentro do magma resfriado excedeu a pressão litostática e iniciou fraturamento nas rochas metassedimentares encaixantes (Burnham, 1979). As vênulas de quartzo em arranjo stockwork localizam-se na porção central do prospecto Pancho Árias, afetando principalmente as rochas metassedimentares encaixantes e estendendo-se aos pórfiros andesíticos. Esse processo provavelmente decorreu de uma mudança na pressão litostática para hidrostática, em uma profundidade crustal entre $1-3 \mathrm{~km}$ e uma concomitante queda de temperatura, a qual pode ter resultado na deposição de quartzo do fluido magmático nas fraturas da carapaça da intrusão (Figura 4.1C). O quartzo pode, portanto, ter sido formado dentro da trama de fraturas resultando na formação de um sistema de veios de quartzo em stockwork ao redor da carapaça da intrusão, atravessando o limite da intrusão e e se estendendo as encaixantes metassedimentares.

$\mathrm{Na}$ porção central do depósito, na zona de alteração potássica, o arranjo em stockwork compreende até $30 \%$ das encaixantes perto da intrusão, essa elevada concentração de veios implica em significativa quantidade de voláteis liberados do melt. Nesses casos, o enriquecimento em voláteis se dá durante a ascensão do melt e pode ter fornecido a flutuabilidade necessária para facilitar colocação em relativamente rasa na crosta (Corbett \& Leach, 1998, Figura 4.1C).

Os primeiros veios de quartzo formados em depósitos de $\mathrm{Cu}$ pórfiro são associados as fases tardias da cristalização. Análises em inclusões fluidas no depósito de Paguna (Eastoe, 1978) indicam que essa formação inicial de veios se desenvolvem em temperaturas de $600-800^{\circ} \mathrm{C}$, temperatura similar a cristalização de melt de composição monzodiorítica, e de fluidos com salinidade de 35-40\% $\mathrm{NaCl}$. Estudos em inclusões fluidas indicam que a maioria dos stockworks e vênulas de quartzo são tipicamente depositados de um fluido quente $\left(>300-500^{\circ} \mathrm{C}\right)$ e hipersalino $(>25-30 \% \mathrm{NaCl})$. Recentes estudos em inclusões fluidas (Eastoe, 1978; Heithersay \& Walshe, 1995) em depósitos pórfiros mostram que durante a formação dos veios de quartzo o vapor e os fluidos salinos partem separadamente do melt resfriado.

É evidente que os fluidos que formaram os arranjos em stockworks são significativamente enriquecidos em metais, com formação principal de molibdenita, pirita e calcopirita, as quais comumente ocorrem associadas aos veios de quartzo presentes nos pórfiros andesíticos e nas rochas encaixantes. 
"O Sistema Magmático do Depósito de Cu-Mo Tipo Pórfiro Pancho Árias, Cordilheira Oriental, Argentina" Rafael Bellozupko Stremel

4.1.4 Estágio IV - Resfriamento, Deposição de Metais e Primeira Formação de Brechas

O principal processo de mineralização em sistemas pórfiros é posterior aos eventos de alteração potássica/propilítica e a formação do stockwork, as quais são, em geral, consideradas muito quentes e com presença de fluidos muito salinos, inibindo a deposição de metais. Logo, a mineralização é caracterizada pela progressiva troca de um ambiente dominado por fluidos magmáticos para um dominado por fluidos mais frios e diluídos, provenientes da interação com águas meteóricas (Gustafson \& Hunt, 1975; Reynolds \& Beane, 1985).

Os fluidos magmáticos e os metais associados, responsáveis pela mineralização no depósito Pancho Árias, provavelmente foram exsolvidos do resfriamento e cristalização do melt em níveis crustais rasos, ao longo de sistemas de fraturas nas margens da intrusão e sob condições de temperatura entre $200-350^{\circ} \mathrm{C}$. A deposição de metais ocorreria ao longo das fraturas recém formadas, fraturas antigas que foram reabertas, vazios existentes nos veios de quartzo e nas porosidades das rochas, que em níveis superficiais encontravam-se saturadas com águas meteóricas (Figura 4.1D), (Gustafson \& Hunt, 1975; Reynolds \& Beane, 1985). O resfriamento desses fluidos pode ter resultado na diminuição do $\mathrm{pH}$ e Eh, em resposta a dissociação dos gases dissolvidos, refletindo na mudança dos minerais silicáticos associados a mineralização. Tal mudança é representada pela zonação inicial, característica de níveis crustais mais profundos, formada por uma assembleia composta por minerais potássicos e por clorita, a qual varia progressivamente para uma zonação característica de níveis mais rasos, formada pela assembleia sericita-argilominerais (Figura 4.2).

Nessa situação, a formação de calcopirita no depósito Pancho Árias é associada aos minerais cálciossilicáticos, os quais se formaram nas porosidades dos pórfiros andesíticos, na matriz dos corpos de brechas associados ao sistema pórfiro e nos veios das encaixantes. A molibdenita, por sua vez, está associada a formação e alteração de clorita-epidoto-carbonato, formados nos veios da encaixante (Watmuff, 1978; Sillitoe \& Gappe, 1984), e a covelita é formada através da alteração supergênica das bordas da calcopirita. 


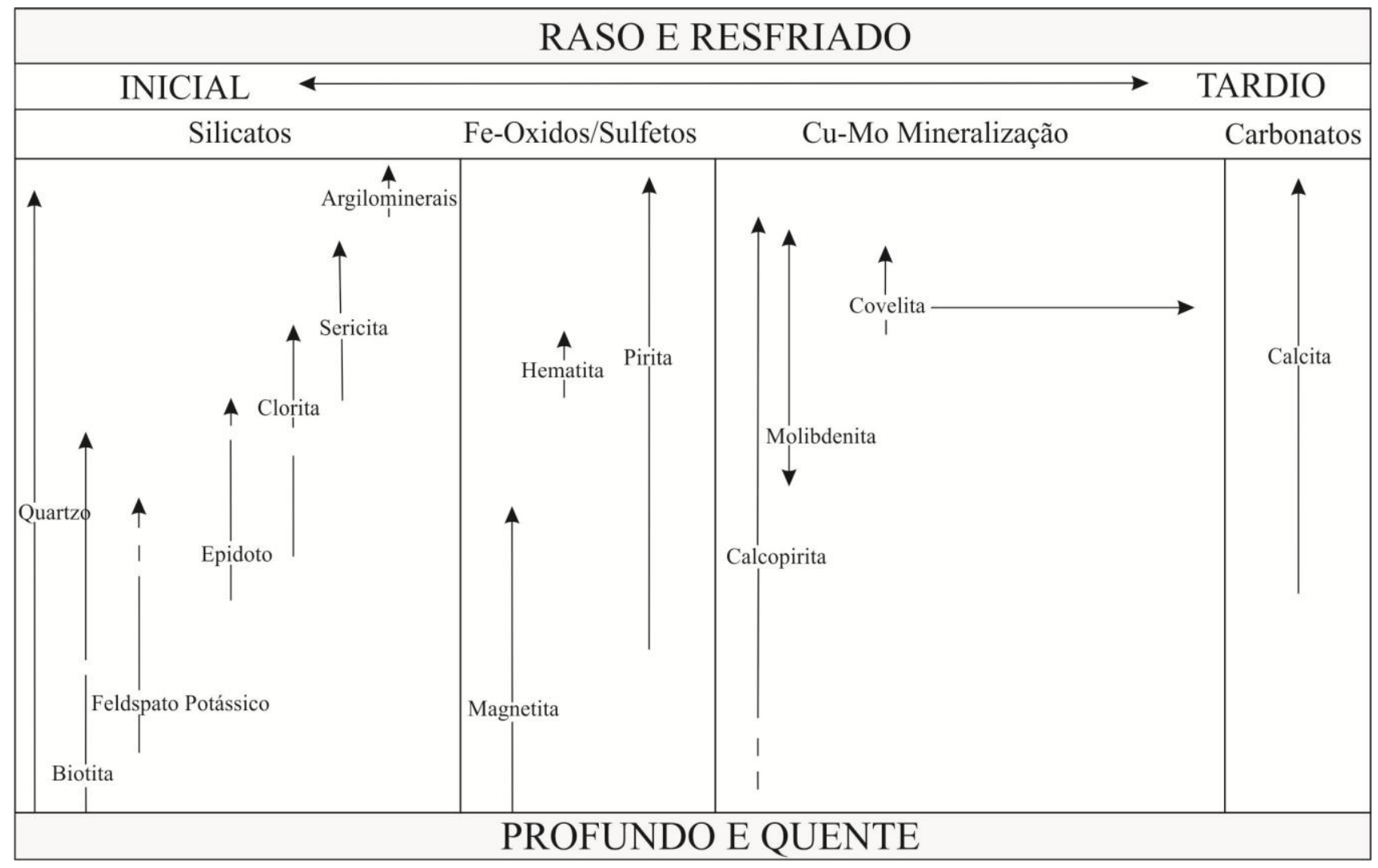

Figura 4.2- Associação mineral desenvolvida ao longo da evolução geológica do depósito de Cu e Mo tipo pórfiro Pancho Árias.

Segundo Sillitoe, 1985, o contato entre as intrusões e suas respectivas encaixantes fornece o local mais propício para a geração de corpos de brecha, as quais apresentam variação textural e mineralógica, ocasionadas por diferentes graus de alteração e de processo de brechação. A primeira formação de corpos de brecha ocorreu de forma concomitante a posterior ao processo de mineralização acima descrito, esse fato é evidenciado pela variação na textura e forma dos fragmentos, os quais variam de sub-arredondados a sub angulosos e nem sempre estão mineralizados. Brechas com essas características podem ser classificada como do tipo intermineral, as quais se formam posteriormente aos principais processos de alteração e mineralização. As evidências para essa conclusão são fornecidas pela restrição de venulações mineralizadas nos fragmentos da brecha e pelo truncamento das zonas de alteração e do arranjo em stockwork pelos corpos de brecha (Figura 4.1D e 4.1E).

Os corpos de brechas do depósito em estudo são caracterizados por conteúdos de metais maiores do que nos stockworks que os circundam, e constituem as partes do corpo de minério com maior teor de metais, o qual atinge seu maior teor com a presença de fragmentos previamente mineralizados. A introdução de $\mathrm{Cu}$ e Mo em brechas intermineral acompanha a alteração potássica, que pode ocorrer de forma ininterrupta ou passar por um processo de renovação, ou pode ser associada à alteração sericítica localizada. 
"O Sistema Magmático do Depósito de Cu-Mo Tipo Pórfiro Pancho Árias, Cordilheira Oriental, Argentina" Rafael Bellozupko Stremel

A elevada variedade de texturas nos cospor de brechas no depósito Pancho Árias pode ter derivado da liberação de fluídos durante o segundo boiling, seguido pela descompressão dos fluidos liberados. Além disso, a ampla ocorrência de fraturas e veios em estruturas de stockworks também podem ser atribuídos aos mesmos processos magmáticos tardios (Burnham, 1979; Burnham, 1985). A presença de fragmentos da rocha encaixante mostram evidência de mistura e transporte dos fragmentos, e evidenciam uma eficiente liberação dos fluidos do corpos porfiríticos (Burnham, 1985). A prolongada liberação de fluidos pode explicar a posição intermineral das brechas do depósito, a qual pode ter sido favorecida pela redução da permeabilidade da rocha, resultado da alteração potássica inicial, da precipitação de quartzo e da mineralização (Founier, 1983).

4.1.5 Estágio V - Alojamento do Stock Monzodiorítico e Segunda Formação de Brechas

O quinto estágio da evolução geológica do depósito Pancho Árias é caracterizado pela intrusão do stock quartzo monzodiorítico que possui arranjo microcristalino e mineralogia idêntico à fácies Monzodiorito com anfibólio e biotita do plúton Las Burras, descrito por Cavalleri, 2005, Hongn et al. (2002), e Mazzuoli et al. (2008). Esses trabalhos obtiveram idades em U-Pb e Rb-Sr entre 14 e 14,5 Ma para esse plúton. As relações de campo e a ausência de uma característica alteração hidrotermal no monzodiorito evidenciam que seu alojamento ocorreu posteriormente aos eventos de cristalização e alteração dos pórfiros andesíticos.

O alojamento do stock gerou um sistema de brechas totalmente desvinculado do sistema das brecha do centro-noroeste (Figura 4.1E). Esse novo sistema, pode ser correlacionado com o sistema de brechas denominado de Brechas Magmático-Hidrotermais Sillitoe (1985), e localiza-se preferencialmente associado ao stock. A formação desses corpos de brecha pode ser explicados pela local dissolução e consequente remoção de material por fluidos liberados do magma ou pela formação de zonas dilatacionais formadas através do desenvolvimento da falha associada a Quebrada de Soquero.

\subsubsection{Estágio VI - Alteração fílica sobreposta e formação dos diques}

O último evento de alteração hidrotermal associado a evolução do depósito Cu-Mo tipo Pórfiro Pancho Árias foi a zona de alteração fílica que sobrepôs a alteração potássica inicial, essa zona de alteração está vinculada a falha da Quebrada de Soquero e é caracterizada pela assembleia quartzosericita-pirita (Figura 4.1E). Dados isotópicos em vários depósitos pórfiros do sudoeste do pacifíco 
"O Sistema Magmático do Depósito de Cu-Mo Tipo Pórfiro Pancho Árias, Cordilheira Oriental, Argentina"

Rafael Bellozupko Stremel

indicam que a sericita é derivada da interação de fluidos meteóricos com fluidos magmáticos e sobrepõe outras assembleias de alteração, além de se desenvolver ao longo de veios em níveis crustais rasos e nas margens intrusivas (ex: depósito de Yandera, Watmuff, 1978; depósito de Frieda River, Britten, 1981; depósito de Batu Hijau, Meldrum et al., 1994; depósito de Goonumbla, Heithersay \& Walshe, 1996).

A ausência de relações de contato com outras fases magmáticas e a falta de dados de datação dificultaram a interpretação sobre a colocação temporal dos diques e sills riodacíticos a traquiandesíticos na evolução do depósito em estudo, porém os interpretamos como último registro magmático observado na área, os quais caracterizam uma fase magmática distal em relação aos pórfiros andesíticos (Figura 4.1E). O fato dos diques estarem afetados por alteração hidrotermal do tipo propilítica sugere a possível presença de outros corpos porfiríticos não aflorantes na região, os quais teriam gerado os fluídos hidrotermais responsáveis pela formação da assembleia de alteração cloritaepidoto-carbonato, observada nos diques. Entretanto, tal sugestão necessita de maiores investigações.

\subsection{Conclusões}

Os dados obtidos neste trabalho nos permite apresentar as seguintes conclusões:

- Os corpos ígneos identificado no depósito de $\mathrm{Cu}-\mathrm{Mo}$ Pancho Árias estão associados ao membro Las Burras, um dos principais eventos magmáticos terciários ocorridos ao longo do lineamento Calama-Olacapato-El Toro, na província morfoestrutural denominada Cordilheira Oriental;

- O depósito Cu-Mo Pancho Árias foi formado pela intrusão de dois corpos pórfiros de composição andesítica um a biotita e outro a anfibólio, cujas relações de campo indicam que PAA é posterior a PAB;

- Dois subsequentes eventos magmáticos, desvinculados da mineralização, também são registrados: a) alojamento de um stock de composição quartzo monzodiorítica, o qual gerou os corpos de brechas aqui denominadas B.s; b) alojamento de um sistema de diques e sills de composição riodacítica a traquiandesítica, representando o último pulso magmático na área;

- Em geral esses eventos magmáticos são peraluminosos a metaluminosos, desenvolvido em contexto tectônico de arco magmático, cuja assinatura isotópica (Sm-Nd e Sr-Sr) indica derivação do mantélica, com algum grau de contaminação crustal; 
- A mineralização está representada pela ocorrência de calcopirita, pirita e molibdenita disseminada e/ou preenchendo fissuras, nos dois pórfiros andesíticos, bem como nas rochas encaixantes e nos corpos de brecha associados a esses pórfiros (B.n);

- A alteração hidrotermal registrada na área é do tipo zonal concêntrica, com um núcleo potássico marcado pela formação de biotita e microclínio secundários, que migra progressivamente para um zona propilítica distal, caracterizada pela formação de clorita, epidoto e carbonato. A zona de alteração fílica ocorre ao longo da falha NESW, associada à Quebrada de Soquero, sendo caracterizada pela associação mica branca-pirita-quartzo. Dados ${ }^{40} \mathrm{Ar} /{ }^{39} \mathrm{Ar}$ sobre biotitas hidrotermais indicam que o processo de alteração hidrotermal teve processo de resfriamento em aproximadamente $15 \mathrm{Ma}$.

- A evolução magmática do depósito propõe que os pórfiros andesíticos derivam de pulsos distintos de um magma comum enriquecido em voláteis. A deposição de metais se inicia concomitantemente a alteração potássica, porém seu maior registro está vinculada à interação dos fluidos hidrotermais e meteóricos, os quais também foram responsáveis pela geração do arranjo em stockwork e pela formação dos corpos de brecha. 
"O Sistema Magmático do Depósito de Cu-Mo Tipo Pórfiro Pancho Árias, Cordilheira Oriental, Argentina"

Rafael Bellozupko Stremel

\section{CAPÍTULO 5}

\section{Referências Bibliográficas.}

Abdel-Rahman A.M., 1994. Nature of biotites from alkaline, calc-alkaline, and peraluminous magmas, Journal of Petrology 35 (2) 525- 541.

Acocella V., Vezzoli L., Omarini R., Matteini M., and Mazzuoli R., 2007, Kinematic variations across Eastern Cordillera at $24^{\circ} \mathrm{S}$ (Central Andes): Tectonic and magmatic implications: Tectonophysics, doi: 10,1016/j. tecto.2007.02.001.

Allmendinger, R., 1986. Tectonic development of the southeastern border of the Puna Plateau, northwestern Argentine Andes. Geological Society of America, Bulletin. 97: 1070-1082.

Alonso, R., Viramonte, J., and Gutiérrez, R., 1984. Puna Austral. Bases para el subprovincilismo geológico de la Puna Argentina. IX Congreso Geológico Argentino, Actas. I: 43-63. Bariloche.

Asmerom, Y., Jacobsen, S. B., Knoll, A. H., Butterfield, N. J., \& Swett, K. (1991). Strontium isotopic variations of Neoproterozoic seawater: implications for crustal evolution. Geochimica et Cosmochimica Acta, 55(10), 2883-2894.

Bachmann, G., Grauert, B., Kramm, U., Lork, A. and Miller, H., 1987. El magmatismo del Cámbrico Medio-Cámbrico Superior en el basamento del noroeste argentino: investigaciones isotópicas y geocronológicas sobre los granitoides de los complejos intrusivos Santa Rosa de Tastil y Cañani. X Congreso Geológico Argentino, 4: 125-127.

Bacon, C.R., 1986, Magmatic inclusions in silicic and intermediate volcanic rocks: Journal of Geophysical Research, v. 91, p. 6091-6112, doi: 10.1029/JB091iB06p06091.

Barnes, H. L. (ed). 1967. Geochemistry of Hydrothermal Ore Deposits. Holt, Rinehart \& Winston Inc, New York. 670.

Borba, M. L., Chemale, F., Kawashita, K., Takehara, L., Babinski, M., and Bruckman, M., 2016. The Bajo de la Alumbrera and Agua Rica $\mathrm{Cu}-\mathrm{Au}$ (Mo) porphyry deposits of Argentina: Genetic constraints on ore formation and sources based on isotope signatures. Ore Geology Reviews, 75, 116-124.

Bossi, G., Muruaga, C. and Gavriloff, I., 1999. Sierras Pampeanas, En: Gonzalez Bonorino, G., Omarini, R. y Viramonte, J. (Editores), Relatorio “Geología del Noroeste argentino", XIV Congreso Geológico Argentino, Salta. I: 329-361. 
"O Sistema Magmático do Depósito de Cu-Mo Tipo Pórfiro Pancho Árias, Cordilheira Oriental, Argentina"

Rafael Bellozupko Stremel

Boynton, W.V. 1984. Geochemistry of the rare earth elements: meteorite studies. In: Henderson, P. (ed), Rare Earth Element Geochemistry, Elsevier, 63-114.

Britten, R. M., 1981. The geology of the Frieda River copper prospect, Papua New Guinea.

Burnham, C. W., 1979. The importance of volatile constituents. The evolution of the igneous rocks, $439,82$.

Burnham, C. W., 1985. Energy release in subvolcanic environments; implications for breccia formation. Economic Geology, 80(6), 1515-1522.

Cabrera, J., Sebrier, M., and Mercier, J.L., 1987, Active normal faulting in high plateaus of Central Andes: The Cuzco region (Peru): Annales Tectonicae, v. 1, p. 116-138.

Caffe, P. and Coira, B., 1999. Complejos de domos volcánicos del Mioceno medio de Puna Norte. Un modelo geológico y metalogenético para yacimientos epitermales de metales de base ricos en plata (estaño). En: Zappettini, E.O. (Ed.) Recursos Minerales de la República Argentina. Instituto de Geología y Recursos Minerales SEGEMAR, Anales 35: 1569-1578. Buenos Aires.

Candela, P. A., and Holland, H. D., 1986. A mass transfer model for copper and molybdenum in magmatic hydrothermal systems; the origin of porphyry-type ore deposits. Economic Geology, 81(1), 1-19.

Cavalleri, P., 2005. Estudio petrográfico y geoquímico de la monzodiorita (Mioceno Medio) “Las Burras", Santa Rosa de Tastil, departamento Rosario de Lerma, provincial de Salta. Tese Profissional.

Cladouhos, T.T., Allmendinger, R.W., Coira, B., and Farrar, E., 1994, Late Cenozoic deformation in the Central Andes: Fault kinematics from the northern Puna, northwestern Argentina and southwestern Bolivia: Journal of South American Earth Sciences, v. 7, p. 209-228, doi: 10.1016/0895-9811(94)90008-6.

Coira, B. and Caffe, P., 1999. Volcanismo cenozoico de la Puna Norte. En González Bonorino, G., Omarini R. y Viramonte, J. (Eds.): Geología del Noroeste Argentino. Relatorio del XIV Congreso Geológico Argentino, Salta. Asociación Geológica Argentina y Universidad Nacional de Salta. Volumen I: 371-386.

Collins, L.G., 1996. The Metasomatic origin of the Cooma complex in southeastern Australia. Theophrastus Contributions to Advanced Studies in Geology 1, 105- 112.

Corbett, G. and Leach, T., 1998. Southwest Pacific Rim Gold-Copper Systems: Structure, Alteration, and Mineralization. Society of Economic Geologists, Especial Publication No6: 31-68. 
"O Sistema Magmático do Depósito de Cu-Mo Tipo Pórfiro Pancho Árias, Cordilheira Oriental, Argentina"

Rafael Bellozupko Stremel

Dalrymple, G. B., Alexander, E. C., Lanphere, M. A., \& Kraker, G. P., 1981. Irradiation of samples for 40Ar/39Ar dating using the Geological Survey TRIGA reactor (No. 1176). USGPO: for sale by the Supt. of Docs., GPO,.

De Silva, S., Zandt, G., Trumbull, R., Viramonte, J., Salas, G., and Jiménez, N., 2006. Large ignimbrite eruptions and volcano-tectonics depressions in the Central Andes: a thermomechanical perspectiva. Eds.: Troise, C., De Natale, G. y Kilburn, C. Mechanism of activity and unrest at large calderas. Geological Society, London, Special Publications. 269: 47-63.

Deng, J., 1986. Phase Equilibrium and Origin of Petrology. China University of Geosciences Press, Wuhan, p. 32.

DePAOLO, D. J., 1981. Trace element and isotopic effects of combined wallrock assimilation and fractional crystallization. Earth and planetary science letters, 53(2), 189-202.

Deruelle, B., 1994, Petrology of Quaternary shoshonitic lavas of Northwestern Argentina, in Harmon, R.S., and Rapela, C.W., eds., Andean magmatism and its tectonic setting: Geological Society of America Special Paper 265, p. 201-217.

Deruelle, B., 1994, Petrology of Quaternary shoshonitic lavas of Northwestern Argentina, in Harmon, R.S., and Rapela, C.W., eds., Andean magmatism and its tectonic setting: Geological Society of America Special Paper 265, p. 201-217.

Dewey, J. F., and S. H. Lamb., 1992. Active tectonics of the Andes. Tectonophysics 205.1: 79-95.

Dietl, C., and Koyi, H.A., 2002, Emplacement of nested diapirs: Result of centrifuge modelling, in Schellart, W.P., and Passchier, C., eds., Analogue Modelling of Large-Scale Tectonic Processes: Journal of the Virtual Explorer, v. 6, p. 81-88.

Drozdzewski, Günter, and R. Mon., 1999. Oppositely-verging thrusting structures in the North Argentine Andes compared with the German Variscides. Acta geológica hispánica 34.2: 185-196.

Eastoe, C. J., 1978. A fluid inclusion study of the Panguna porphyry copper deposit, Bougainville, Papua New Guinea. Economic Geology, 73(5), 721-748.

Ford, J. H., and Green, D. C., 1977. An oxygen-and hydrogen-isotope study of the Panguna porphyry-copper deposit, Bougainville. Journal of the Geological Society of Australia, 24(12), 63-80.

Fournier, R. O., 1983. A method of calculating quartz solubilities in aqueous sodium chloride solutions. Geochimica et Cosmochimica Acta, 47(3), 579-586.

Frost, B. R., Barnes, C. G., Collins, W. J., Arculus, R. J., Ellis, D. J., and Frost, C. D., 2001. A geochemical classification for granitic rocks. Journal of petrology, 42(11), 2033-2 
"O Sistema Magmático do Depósito de Cu-Mo Tipo Pórfiro Pancho Árias, Cordilheira Oriental, Argentina"

Rafael Bellozupko Stremel

Galli, C., 1995. Estratigrafía y sedimentología del Subgrupo Metán (Grupo Orán-Terciario), provincia de Salta. Argentina. Universidad Nacional de Salta, Escuela del doctorado. Tesis Doctoral, 109p.

Gioia, S. M. C. L., \& Pimentel, M. M., 2000. The Sm-Nd isotopic method in the Geochronology Laboratory of the University of Brasília. Anais da Academia Brasileira de Ciências, 72(2), 219-245.

Gioncada, A., Vezzoli, L., Mazzuoli, R., Omarini, R., Nonnotte, P., and Guillou, H., 2010. Pliocene intraplate-type volcanism in the Andean foreland at $26^{\circ} 10^{\prime} \mathrm{S}, 64^{\circ} 40^{\prime} \mathrm{W}$ (NW Argentina): Implications for magmatic and structural evolution of the Central Andes. Lithosphere, 2(3), 153-171.

Goddard, P., Willson, J.J., Couch, S., and Viramonte, J., 1999, The evolution of El Quevar volcanic complex, 1516 Geological Society of America Bulletin, November/December 2008 Salta Province, Argentina: Congreso Geológico Argentino, 14th, v. 2, p. 225-227.

Gubbels, T. L., Isacks, B. L., and Farrar, E., 1993. High-level surfaces, plateau uplift, and foreland development, Bolivian central Andes. Geology, 21(8), 695-698.

Gustafson, L. B., and Hunt, J. P., 1975. The porphyry copper deposit at El Salvador, Chile. Economic Geology, 70(5), 857-912.

Hattori, K., and Sato, H., 1996. Magma evolution recorded in plagioclase zoning in 1991 Pinatubo eruption products. American Mineralogist, 81(7-8), 982-994.

Haschke, M., and Ben-Avraham, Z., 2005. Adakites from collision-modified lithosphere. Geophysical Research Letters, 32(15).

Haslam H.W., 1968. The crystallization of intermediate and acid magmas at Ben Nevis, Scotland. J. Petrology 9 84-104.

Hedenquist, J. W., \& Lowenstern, J. B., 1994. The role of magmas in the formation of hydrothermal ore deposits. Nature, 370(6490), 519-527.

Heithersay, P. S., and Walshe, J. L., 1995. Endeavour 26 North; a porphyry copper-gold deposit in the Late Ordovician, shoshonitic Goonumbla volcanic complex, New South Wales, Australia. Economic Geology, 90(6), 1506-1532.

Hemley, J. J., and Jones, W. R., 1964. Chemical aspects of hydrothermal alteration with emphasis on hydrogen metasomatism. Economic Geology, 59(4), 538-569.

Hernández, R., Galli, C., and Reynolds, J., 1999. Estratigrafía del terciario en el noroeste argentino. In: González Bonorino, G., Omarini, R. y Viramonte, J. (Editores), Relatorio “Geología del Noroeste argentino", XIV Congreso Geológico Argentino, Salta, I, 316-328. 
"O Sistema Magmático do Depósito de Cu-Mo Tipo Pórfiro Pancho Árias, Cordilheira Oriental, Argentina"

Rafael Bellozupko Stremel

Hey, M., H., 1954. A new review of the chlorites. Mineralogical Magazine 30, 277-292.

Hilley, G.E., and Strecker, M.R., 2005, Processes of oscillatory basin filling and excavation in a tectonically active orogen: Quebrada del Toro Basin, NW Argentina: Geological Society of America Bulletin, v. 117, p. 887-901, doi: 10.1130/B25602.1.

Hongn, F.D., Tubía, J. M., Aranguren and Mon, R., 2002. La Monzodiorita Las Burras: un plutón mioceno en el batolito de Tastil, Cordillera Oriental, Argentina. XV Congreso Geológico Argentino, Acta 1, 128-133.

Hongn, F.D., Tubía, J.M., Aranguren, A., and Mon, R., 2003. The Tastil Batolith (Cordillera Oriental, Argentina): A case of Early Cambrian extension-related magmatism in the border of Gondwana. $18^{\circ}$ LAK, Terra Nostra 2: 4.

Hongn, F.D., Tubia, J.M., Aranguren, A., Mon, R., and Vegas, N., 2005, Intrusion del Granito de Tastil en Areniscas Eopaleozoicas (Angosto de la Quesera, Cordillera Oriental, Salta): Congreso Geológico Argentino, 16th, v. 1, p. 509-514.

Hooper, B., Heithersay, P. S., Mills, M. B., Lindhorst, J. W., and Freyberg, J., 1996. Shoshonite-hosted endeavour 48 porphyry copper-gold deposit, Northparkes, central New South Wales. Australian Journal of Earth Sciences, 43(3), 279-288.

Horton, B. K., and DeCelles, P. G., 1997. The modern foreland basin system adjacent to the Central Andes. Geology, 25(10), 895-898.

HousH, T. B., and Luhr, J. F., 1991. Plagioclase-melt equilibria in hydrous systems. American Mineralogist, 76(3-4), 477-492.

Hrouda, F., Táborská, Š., Schulmann, K., Ježel, J., and Dolejš, D., 1999, Magmatic fabric and rheology of comingled magmas in the Nasavrky Plutonic Complex (E Bohemia): Implications for intrusive strain regime and emplacement mechanism: Tectonophysics, v. 307, p. 93-111, doi: 10.1016/S0040-1951(99)00121-3.

Isacks, B.L., 1988, Uplift of the Central Andean plateau and bending of the Bolivian orocline: Journal of Geophysical Research, v. 93, p. 3211-3231, doi: 10.1029/ JB093iB04p03211.

Japan Internacional Cooperation Agency (JICA), 2002. Report on regional survey for mineral resources in the Northwest area, the Argentine republic. Metal Mining Agency of Japan.

Johannes, W. 1978. Melting of plagioclase in the system Ab-An- $\mathrm{H} 2 \mathrm{O}$ and Qz-Ab-An- $\mathrm{H}_{2} \mathrm{O}$ at $\mathrm{H}_{2} \mathrm{O}$ $=5 \mathrm{kbars}$, an equilibrium problem. Contributions to Mineralogy and Petrology 66, $295 Đ 303$.

Kay, M.S., and Mpodozis, C., 2001, Central Andean ore deposits linked to evolving shallow subduction systems and thickening crust: GSA Today, v. 11, no. 3, p. 4-9, doi: 10.1130/1052-5173(2001)011<0004:CAODLT>2.0.CO;2 
"O Sistema Magmático do Depósito de Cu-Mo Tipo Pórfiro Pancho Árias, Cordilheira Oriental, Argentina"

Rafael Bellozupko Stremel

Kay, S.M., Coira, B., and Viramonte, J., 1994, Young mafic back arc volcanic rocks as indicators of continental lithospheric delamination beneath Argentine Puna plateau, central Andes: Journal of Geophysical Research, v. 99, p. 24,323-24,339, doi: 10.1029/94JB00896.

Kay, S. M., Woll, B., and Manning, M., 1999. Magmatic sources and tectonic setting of Gondwana margin Ordovician magmas, northern Puna of Argentina and Chile. Laurentia- Gondwana Connections before Pangea, 336, 145.

Kilmurray, J., and Igarzábal, A., 1971. Petrografía y rasgos geomórficos del batolito granítico de Santa Rosa de Tastil, Provincia de Salta, Rep. Argentina. Revista de la Asociación Geológica Argentina, 26(4), 417-438.

Kosaka, H., and Wakita, K., 1978. Some geologic features of the Mamut porphyry copper deposit, Sabah, Malaysia. Economic Geology, 73(5), 618-627.

Leake, B.E., Woolley, A.R., Arps, C.E.S., Birch, W.D., Gilbert, M.C., Grice, J.D., Hawthorne, F.C., Kato, A., Kisch, H.J., Krivovichev, V.G., Linthout, K., Laird, J., Mandarino, J.A., Maresch, W.V., Nickel, E.H., Rock, N.M.S., Schumacher, J.C., Smith, D.C., Stephenson, N.C.N., Ungaretti, L., Whittaker, E.J.W., and Youzhi, G., 1997. Nomenclature of amphiboles: Report of the Subcommittee on Amphiboles of the International Mineralogical Association, Commission on New Minerals and Mineral Names. American Mineralogist, 82, 1019-1037.

L'Heureux, I., and Fowler, A. D., 1994. A nonlinear dynamical model of oscillatory zoning in plagioclase. American Mineralogist, 79(9-10), 885-891.

Lowell, J., and Guilbert, J., 1970, Lateral and vertical alteration zoning in porphyry ore deposits. Economic Geology, 65:373-408.

MacDonald, G. D., and Arnold, L. C., 1994. Geological and geochemical zoning of the Grasberg igneous complex, Irian Jaya, Indonesia. Journal of Geochemical Exploration, 50(1), 143-178.

Marre, J., 1986, The structural analysis of granitic rocks: London, North Oxford Academic, 123 p.

Marrett, R., and Emerman, S. H., 1992. The relations between faulting and mafic magmatism in the Altiplano-Puna plateau (central Andes). Earth and Planetary Science Letters, 112(1), 53-59.

Marrett, R., and Strecker, M.R., 2000, Response of intracontinental deformation in the central Andes to late Cenozoic reorganization of South American Plate motions: Tectonics, v. 19, p. $452-$ 467, doi: 10.1029/1999TC001102.

Marrett, R.A., Allmendinger, R.W., Alonso, R.N., and Drake, R.E., 1994, Late Cenozoic tectonic evolution of the Puna plateau and adjacent foreland, northwestern Argentine Andes: Journal of South American Earth Sciences, v. 7, p. 179-207, doi: 10.1016/0895-9811(94)90007-8. 
"O Sistema Magmático do Depósito de Cu-Mo Tipo Pórfiro Pancho Árias, Cordilheira Oriental, Argentina"

Rafael Bellozupko Stremel

Martin F.A., 2007. Estudio petrográfico del prospecto Pancho Arias Vizcacheral (Mioceno Medio), Cordillera Oriental, Provincia de Salta. TesisProfesional, Faculdade de Ciencias Naturales, Escuela de Geologia, Universidad Nacional de Salta, Argentina, 57p.

Matteini, M., Mazzuoli, R., Omarini, R., Cas, R., and Maas, R., 2002. Geodynamical evolution of Central Andes at $24 \mathrm{~S}$ as inferred by magma composition along the Calama- OlacapatoEl Toro transversal volcanic belt. Journal of Volcanology and Geothermal Research, $118(1), 205-228$.

Matteini, M., Mazzuoli, R., Omarini, R., Cas, R., and Maas, R., 2002. The geochemical variations of the upper cenozoic volcanism along the Calama-Olacapato-El Toro transversal fault system in central Andes ( $24 \mathrm{~S})$ : petrogenetic and geodynamic implications. Tectonophysics, 345(1), 211-227.

Matteini, M., Acocella, V., Vezzoli, L., Dini, A., Gioncada, A., Guillou, H., Mazzuoli, R., Omarini, R., Uttini, A. and Hauser, N., 2005.Geology and petrology of the Las Burras-Almagro Magmatic Complex, Salta, Argentina. XVI Congreso Geológico Argentino, La Plata. Acta I: 479-484.

Mazzuolli, R., Vezzoli, L., Omarini, R., Acocella, V., Gioncada, A., Matteini, M, Dini, A., Guillou, A., Hauser, N., Uttini, A., and Scaillet, S., 2008. Miocene magmatism and tectonics of the easternmost sector of the Calama-Olacapato-El Toro fault system in Central Andes at $\sim 24^{\circ} \mathrm{S}$ : Insights into the evolution of the Eastern Cordillera. GeologicalSociety of America Bulletinv. 120; no. 11/12; p. 1493- 1517; doi: 10.1130/B26109.1.

McDougall, I., \& Harrison, T. M., 1988. Geochronology and Thermochronology by the ${ }^{40} \mathrm{Ar} /{ }^{39} \mathrm{Ar}$ method. New York.

McMillan, W. J., and Panteleyev, A., 1988. Porphyry copper deposits. Geoscience Canada, Reprint Series, 3, 45-58.

Meldrum, S. J., Aquino, R. S., Gonzales, R. I., Burke, R. J., Suyadi, A., Irianto, B., \& Clarke, D. S., 1994. The Batu Hijau porphyry copper-gold deposit, Sumbawa island, Indonesia. Journal of Geochemical Exploration, 50(1), 203-220.

Melik, R., 1999. ${ }^{40} \mathrm{Ar} /{ }^{39} \mathrm{Ar}$ geochronology results form Las Burras, Cerro Samenta and from the Faja Eruptiva, Northwestern Argentina. Em http//:136.177.81.51/projects/agetitle.html (USGS).

Middlemost, E., A., K., 1994. Naming materials in magma/igneous rock system. Earth-Science Reviews, 37, 215-224.

Mon, R., 1999, Cordillera Oriental, in Gonzalez Bonorino, G.,et al., eds., Geologia del Noroeste Argentino: Relatorio Congreso Geológico Argentino, 14th, p. 426-431. 
"O Sistema Magmático do Depósito de Cu-Mo Tipo Pórfiro Pancho Árias, Cordilheira Oriental, Argentina"

Rafael Bellozupko Stremel

Moreno, J., 1970. Estratigrafía y paleogeografía del Cretácico superior de la Cuenca del Noroeste Argentino, con especial mención de los Subgrupos Balbuena y Santa Bárbara. Revista de la Asociación Geológica Argentina XXV (1): 9-44.

Moya M., 1998. El Paleozoico inferior en la Sierra de Mojotoro, Salta- Jujuy. Revista de la Asociación Geológica Argentina, 53 (2): 219-238.

Moya M., 1999. El Ordovícico en los Andes del norte argentino. XIV Congreso Geológico Argentino, Salta.

Moya M. and Monteros, J., 1999. El Ordovícico Tardío y el Silúrico en el borde occidental de la Cordillera Oriental argentina. XIV Congreso Geológico Argentino, Salta.

Mustard, R., Ulrich, T., Kamenetsky, V. S., \& Mernagh, T., 2006. Gold and metal enrichment in natural granitic melts during fractional crystallization. Geology, 34(2), 85-88.

Nachit, H., Ibhi, A., Abia, E. H., and Ohoud, M. B., 2005. Discrimination between primary magmatic biotites, reequilibrated biotites and neoformed biotites. Comptes Rendus Geoscience, 337(16), 1415-1420.

Nachit H., Razafimahefa N., Stussi J.M., Carron J.P., 1985. Composition chimique des biotites et typologie magmatique des granitoids. Comtes Rendus Hebdomadaires de l' Academie des Sciences 301 (11) (1985) 813-818.

Omarini, R. H., and Gotze, H. J., 1991. Global Geoscience Transect 6: Central Andean Transect, Nazca Plate to Chaco Plains Southwestern Pacific Ocean, Northern Chile and Northern Argentina: Am. Amer.Geophys. Union.

Omarini, R.H., Sureda, R.J., Götze, H.-J., Seilacher, A., and Pfluger, F., 1999, Puncoviscana folded belt in northwestern Argentina: Testimony of Late Proterozoic Rodinia fragmentation and pre Gondwana collisional episodes: International Journal of Earth Sciences, v. 88, p. 76-97, doi: $10.1007 / \mathrm{s} 005310050247$.

Orville, P.M., 1963. Alkali ion exchange between vapor and feldspar phase. American Journal of Sciences 261, 201-237.

Paterson, S.R., and Vermon, R.H., 1995, Bursting the bubbles of ballooning plutons; a return to nested diapirs emplacement by multiple processes: Geological Society of America Bulletin, v. 107, p. 1356-1380, doi: 10.1130/ 0016-7606(1995)107<1356:BTBOBP>2.3.CO;2.

Pearce, J. A., Harris, N. B. W. and Tindle, A. G., 1984. Trace element discrimination diagrams for the tectonic interpretation of granitic rocks. Journal of Petrology 25, 956-983.

Perugini, D., and Poli, G., 2000, Chaotic dynamics and fractals in magmatic interaction processes: A different approach to the interpretation of mafic microgranular enclaves: Earth and Planetary Science Letters, v. 175, p. 93-103, doi: 10.1016/S0012-821X(99)00282-4. 
"O Sistema Magmático do Depósito de Cu-Mo Tipo Pórfiro Pancho Árias, Cordilheira Oriental, Argentina"

Rafael Bellozupko Stremel

Petrinovic, I.A., Riller, U., and Brod, J.A., 2005, The Negra Muerta Volcanic Complex, southern Central Andes: Geochemical characteristics and magmatic evolution of an episodically active volcanic centre: Journal of Volcanology and Geothermal Research, v. 140, p. 295-320, doi: 10.1016/j.jvolgeores.2004.09.002.

Petrinovic, I. A., Riller, U., Brod, J. A., Alvarado, G., and Arnosio, M., 2006. Bimodal volcanism in a tectonic transfer zone: evidence for tectonically controlled magmatism in the southern Central Andes, NW Argentina. Journal of Volcanology and Geothermal Research, 152(3), 240-252.

Pringle, G. J., Trembath, L. T., \& Pajari, G. E. (1974). Crystallization history of a zoned plagioclase. Mineral Mag, 39, 867-877.

Reyes, F. C., and Salfity, J. A.. 1973. Consideraciones sobre la estratigrafía del Cretácico (Subgrupo Pirgua) del noroeste argentino. In 5 Congreso Geológico Argentino (Vol. 3).

Reynolds, T. J., and Beane, R. E., 1985. Evolution of hydrothermal fluid characteristics at the Santa Rita, New Mexico, porphyry copper deposit. Economic Geology, 80(5), 1328-1347.

Reynolds, J. H., Galli, C. I., Hernández, R. M., Idleman, B. D., Kotila, J. M., Hilliard, R. V., and Naeser, C. W., 2000. Middle Miocene tectonic development of the transition zone, Salta Province, Northwest Argentina: magnetic stratigraphy from the Metan Subgroup, Sierra de Gonzalez. Geological Society of America Bulletin, 112(11), 1736-1751.

Richards, J. P., 2003. Tectono-magmatic precursors for porphyry $\mathrm{Cu}$-(Mo-Au) deposit formation. Economic Geology, 98(8), 1515-1533.

Riller, U.,Petrinovic, I.A, Ramelow, J., Strecker, M. and Oncken, O. 2001. Late Cenozonic tectonism, collapse caldera and plateau formation in the Central Andes. Earth and Planetary Science Letters 188:299-311.

Riller, U., and Oncken, O., 2003. Growth of the Central Andean Plateau by tectonic segmentation is controlled by the gradient in crustal shortening. The Journal of geology 111.3 (): 367-384.

Roddick, J. C., 1983. High precision intercalibration of 40 Ar-39 Ar standards. Geochimica et Cosmochimica Acta, 47(5), 887-898.

Russo, A., and Serraiotto, A., 1979. Contribución al conocimiento de la estratigrafía delterciario en el Noroeste Argentino. VII. Congr. Geol. Argentino, (I): 715-730.

Salfity, J.A., Gorustovich, S.A., Moya, M.C., and Amengual, A., 1984, Marco tectonico de la sedimentation y efusividad Cenozoicas en la Puna Argentina: Congreso Geológico Argentino, 9th, v. 1, p. 539-554.

Salfity, J., Monaldi, C., Marquillas, R. and Gonzáles, R., 1993. La inversión tectónica del Umbral de los Gallos en la Cuenca del Grupo Salta durante la Fase incaica. XII Congreso Geológico 
"O Sistema Magmático do Depósito de Cu-Mo Tipo Pórfiro Pancho Árias, Cordilheira Oriental, Argentina"

Rafael Bellozupko Stremel

Argentino y $2^{\circ}$ Congreso de Exploración de Hidrocarburos, Actas, 3: 200-210, Mendoza, Argentina.

Sánchez, M., 1999. Sedimentología y paleogeografía Grupo Mesón (Cámbrico) Tomo I Relatorio del XIV Congreso Geológico Argentino, Salta 1999 (126-133).

Sánchez, M. and Salfity, J., 1990. Litofacies del Grupo Mesón (Cámbrico) en el oeste del Valle de Lerma (Cordillera Oriental argentina). X Congreso Geológico Argentino, Actas, 2: 129-132. San Juan.

Scheuber, E., and Klaus-J., R., 1992. Magmatic arc tectonics in the Central Andes between 21 and 25 S." Tectonophysics 205.1: 127-140.

Scheuber, E., and Giese, P., 1999. Architecture of the Central Andes_-a compilation of geoscientific data along a transect at 21 S. Journal of South American Earth Sciences, 12(2), 103-107.

Shand, S. J., 1943. Eruptive rocks: Their genesis, composition, and classification, with a chapter on meteorites. J. Wiley \& sons, Incorporated.

Sillitoe, R. H., 1977. Permo-Carboniferous, Upper Cretaceous, and Miocene porphyry Copper-type mineralization in the Argentinian Andes. Economic Geology, 72:99-109.

Sillitoe, R. H., 1985. Ore-related breccias in volcanoplutonic arcs. Economic Geology, 80(6), $1467-$ 1514.

Sillitoe, R. H., 2010. Porphyry copper systems. Economic geology, 105(1), 3-41.

Sillitoe, R. H., and Gappe, I. M., 1984. Philippine porphyry copper deposits: Geologic setting and characteristics (Vol. 14). CCOP Project Office, UNDP Technical Support for Regional Offshore Prospecting in East Asia (RAS/81/120).

Sinclair, W. D. (2007). Porphyry deposits. Mineral deposits of Canada: A synthesis of major deposittypes, district metallogeny, the evolution of geological provinces, and exploration methods: 'Geological Association of Canada, Mineral Deposits Division, Special Publication, 5, 223243.

Snyder, D., 2000, Thermal effects of the intrusion of basaltic magma into a more silicic magma chamber and implications for eruption triggering: Earth and Planetary Science Letters, v. 175, p. 257-273, doi: 10.1016/ S0012-821X(99)00301-5.

Sobolev, S. V., and Babeyko, A. Y., 2005. What drives orogeny in the Andes?. Geology, 33(8), 617620.

Steiger, R., \& Jäger, E., 1977. Subcommission on geochronology: convention on the use of decay constants in geo-and cosmochronology. Earth and planetary science letters, 36(3), 359-362.

Streckeisen, A., 1976. To each plutonic Rock its proper name. Earth Science Reiew. Vol. 12: 1-33. 
"O Sistema Magmático do Depósito de Cu-Mo Tipo Pórfiro Pancho Árias, Cordilheira Oriental, Argentina"

Rafael Bellozupko Stremel

Streckeisen, A., and Le Maitre, R.W., 1979, A chemical approximation to the modal QAPF classification of igneous rocks: Neues Jahrbuch für Mineralogie- Abhandlungen, v. 136, p. 169-206.

Sylvester, A.G., 1988, Strike-slip faults: Geological Society of America Bulletin, v. 100, p. 16661703, doi: 10.113 0/0016-7606 100<1666:SSF>2.3.CO;2.

Thompson R.N. 1982. Magmatism of the British Tertiary volcanic province. Scottish Journal of Geology, 18:49-107.

Thorpe, R.S., O'Callaghan, L.J., and Francis, P.W., 1984, Relative roles of source composition, fractional crystallization and crustal contamination in the petrogenesis of Andean volcanic rocks: Philosophical Transactions of the Royal Society of London-A, v. 310, p. 675-692, doi: 10.1098/rsta.1984.0014.

Titley, S. R., and Beane, R. E., 1981. Porphyry copper deposits. Part I, Geologic settings, petrology, and tectonogenesis: Economic Geology, 75th Anniversary Volume, 214-235.

Trumbull, R.B., Wittenbrink, R., Hahne, K., Emerman, R., Büsch, W., Gerstenberger, H., and Siebel, W., 1999, Evidence for Late Miocene to Recent contamination of arc andesites by crustal melts in the Chilean Andes $\left(25-26^{\circ} \mathrm{S}\right)$ and its geodynamic implications: Journal of South American Earth Sciences, v. 12, p. 135-155, doi: 10.1016/S0895-9811(99)00011-5.

Viramonte, J. G., Kay, S. M., Becchio, R., Escayola, M., and Novitski, I., 1999. Cretaceous rift related magmatism in central-western South America. Journal of South American Earth Sciences, 12(2), 109-121.

Watmuff, G., 1978. Geology and alteration-mineralization zoning in the central portion of the Yandera porphyry copper prospect, Papua New Guinea. Economic geology, 73(5), 829-856.

Winchester, J. A., and Floyd, P. A., 1977. Geochemical discrimination of different magma series and their differentiation products using immobile elements. Chemical geology, 20, 325-343.

Xu, X.W., Cai, X.P., Zhang, B.L., Wang, J., 2004. Explosive microfractures induced by Kmetasomatism. Journal of Asia Earth Sciences 23, 421-423.

Xu, X. W., Zhang, B. L., Liang, G. H., \& Qin, K. Z. (2012). Zoning of mineralization in hypogene porphyry copper deposits: Insight from comb microfractures within quartz-chalcopyrite veins in the Hongshan porphyry $\mathrm{Cu}$ deposit, western Yunnan, SW China. Journal of Asian Earth Sciences, 56, 218-228.

Zartman, R. E., and Haines, S. M., 1988. The plumbotectonic model for Pb isotopic systematics among major terrestrial reservoirs - a case for bi-directional transport. Geochimica et Cosmochimica Acta, 52(6), 1327-1339. 
"O Sistema Magmático do Depósito de Cu-Mo Tipo Pórfiro Pancho Árias, Cordilheira Oriental, Argentina" Rafael Bellozupko Stremel

ANEXOS 
"O Sistema Magmático do Depósito de Cu-Mo Tipo Pórfiro Pancho Árias, Cordilheira Oriental, Argentina" Rafael Bellozupko Stremel

Anexo 1 - TABELA DE PONTOS VISITADOS

\begin{tabular}{|c|c|c|}
\hline Ponto & $S$ & W \\
\hline PA 200 & $24^{\circ} 15^{\prime} 53.74^{\prime \prime S}$ & $65^{\circ} 50^{\prime} 53.09^{\prime \prime} \mathrm{O}$ \\
\hline PA 201 & $24^{\circ} 15^{\prime} 54.94^{\prime \prime S}$ & $65^{\circ} 50^{\prime} 48.61 " \mathrm{O}$ \\
\hline PA 202 & $24^{\circ} 15^{\prime} 41.20^{\prime \prime S}$ & $65^{\circ} 50^{\prime} 40.65^{\prime \prime} \mathrm{O}$ \\
\hline PA 203 & $24^{\circ} 15^{\prime} 36.64^{\prime \prime S}$ & $65^{\circ} 50^{\prime} 42.73 " \mathrm{O}$ \\
\hline PA 204 & $24^{\circ} 15^{\prime} 42.75^{\prime \prime S}$ & $65^{\circ} 50^{\prime} 41.14^{\prime \prime O}$ \\
\hline PA 205 & $24^{\circ} 15^{\prime} 46.65^{\prime \prime S}$ & $65^{\circ} 50^{\prime} 48.66 " \mathrm{O}$ \\
\hline PA 206 & $24^{\circ} 15^{\prime} 50.51^{\prime \prime S}$ & $65^{\circ} 50^{\prime} 51.26 " \mathrm{O}$ \\
\hline PA 207 & $24^{\circ} 15^{\prime} 48.68^{\prime \prime S}$ & $65^{\circ} 50^{\prime} 54.73 " \mathrm{O}$ \\
\hline PA 208 & $24^{\circ} 15^{\prime} 52.85^{\prime S}$ & $65^{\circ} 50^{\prime} 53.49^{\prime \prime} \mathrm{O}$ \\
\hline PA 209 & $24^{\circ} 15^{\prime} 52.53^{\prime \prime S}$ & $65^{\circ} 50^{\prime} 48.311^{\prime \prime O}$ \\
\hline PA 210 & $24^{\circ} 16^{\prime} 19.76^{\prime \prime S}$ & $65^{\circ} 51^{\prime} 38.02^{\prime \prime O}$ \\
\hline PA 211 & $24^{\circ} 15^{\prime} 55.49^{\prime \prime S}$ & $65^{\circ} 50^{\prime} 6.988^{\prime \prime O}$ \\
\hline PA 212 & $24^{\circ} 15^{\prime} 49.86^{\prime \prime S}$ & $65^{\circ} 50^{\prime} 32.08^{\prime \prime O}$ \\
\hline PA 213 & $24^{\circ} 15^{\prime} 52.83^{\prime \prime S}$ & $65^{\circ} 50^{\prime} 36.45^{\prime \prime O}$ \\
\hline PA 214 & $24^{\circ} 15^{\prime} 57.51^{\prime \prime S}$ & $65^{\circ} 50^{\prime} 44.77^{\prime \prime O}$ \\
\hline PA 215 & $24^{\circ} 16^{\prime} 0.79^{\prime \prime S}$ & $65^{\circ} 50^{\prime} 50.30^{\prime \prime} \mathrm{O}$ \\
\hline PA 216 & $24^{\circ} 16^{\prime} 4.05^{\prime \prime S}$ & $65^{\circ} 50^{\prime} 53.57 " \mathrm{O}$ \\
\hline PA 217 & $24^{\circ} 15^{\prime} 45.79^{\prime \prime} \mathrm{S}$ & $65^{\circ} 50^{\prime} 25.80^{\prime \prime O}$ \\
\hline PA 218 & $24^{\circ} 15^{\prime} 30.20^{\prime \prime S}$ & $65^{\circ} 50^{\prime} 45.75^{\prime \prime O}$ \\
\hline PA 219 & $24^{\circ} 15^{\prime} 48.36^{\prime \prime S}$ & $65^{\circ} 51^{\prime} 40.38^{\prime \prime O}$ \\
\hline PA 220 & $24^{\circ} 15^{\prime} 47.30^{\prime \prime S}$ & $65^{\circ} 51^{\prime} 44.44 " \mathrm{O}$ \\
\hline PA 221 & $24^{\circ} 16^{\prime} 0.02^{\prime \prime S}$ & $65^{\circ} 50^{\prime} 53.34 " \mathrm{O}$ \\
\hline PA 222 & $24^{\circ} 15^{\prime} 55.96 " \mathrm{~S}$ & $65^{\circ} 50^{\prime} 55.52 " \mathrm{O}$ \\
\hline PA 223 & $24^{\circ} 15^{\prime} 54.68^{\prime \prime S}$ & $65^{\circ} 50^{\prime} 54.96 " \mathrm{O}$ \\
\hline PA 224 & $24^{\circ} 15^{\prime} 53.55^{\prime \prime S}$ & $65^{\circ} 50^{\prime} 50.10^{\prime \prime} \mathrm{O}$ \\
\hline PA 225 & $24^{\circ} 15^{\prime} 59.40 " \mathrm{~S}$ & $65^{\circ} 50^{\prime} 57.97 " \mathrm{O}$ \\
\hline PA 226 & $24^{\circ} 15^{\prime} 56.74^{\prime \prime} \mathrm{S}$ & $65^{\circ} 50^{\prime} 56.07 " \mathrm{O}$ \\
\hline PA 227 & $24^{\circ} 15^{\prime} 55.04^{\prime \prime S}$ & $65^{\circ} 50^{\prime} 55.85^{\prime \prime O}$ \\
\hline PA 228 & $24^{\circ} 15^{\prime} 59.66^{\prime \prime S}$ & $65^{\circ} 50^{\prime} 59.00^{\prime \prime O}$ \\
\hline PA 229 & $24^{\circ} 16^{\prime} 3.85^{\prime \prime} \mathrm{S}$ & $65^{\circ} 51^{\prime} 0.88^{\prime \prime O}$ \\
\hline PA 230 & $24^{\circ} 16^{\prime} 7.45^{\prime \prime S}$ & $65^{\circ} 51^{\prime} 0.94 " \mathrm{O}$ \\
\hline PA 231 & $24^{\circ} 16^{\prime} 12.57^{\prime \prime S}$ & $65^{\circ} 50^{\prime} 56.85^{\prime \prime} \mathrm{O}$ \\
\hline PA 232 & $24^{\circ} 15^{\prime} 36.66^{\prime \prime S}$ & $65^{\circ} 50^{\prime} 57.58 \mathrm{\prime O}$ \\
\hline PA 233 & $24^{\circ} 15^{\prime} 54.98^{\prime \prime} \mathrm{S}$ & $65^{\circ} 50^{\prime} 13.45^{\prime \prime} \mathrm{O}$ \\
\hline PA 234 & $24^{\circ} 15^{\prime} 38.70^{\prime \prime} \mathrm{S}$ & $65^{\circ} 50^{\prime} 26.05^{\prime \prime O}$ \\
\hline PA 235 & $24^{\circ} 15^{\prime} 32.71^{\prime \prime} \mathrm{S}$ & $65^{\circ} 50^{\prime} 31.54 " \mathrm{O}$ \\
\hline PA 236 & $24^{\circ} 15^{\prime} 31.60^{\prime \prime S}$ & $65^{\circ} 50^{\prime} 31.79^{\prime \prime O}$ \\
\hline PA 237 & $24^{\circ} 15^{\prime} 30.58^{\prime \prime} \mathrm{S}$ & $65^{\circ} 50^{\prime} 33.32 " \mathrm{O}$ \\
\hline PA 238 & $24^{\circ} 15^{\prime} 28.92 " \mathrm{~S}$ & $65^{\circ} 50^{\prime} 40.55^{\prime \prime O}$ \\
\hline PA 239 & $24^{\circ} 15^{\prime} 39.56^{\prime \prime S}$ & $65^{\circ} 51^{\prime} 38.77^{\prime \prime O}$ \\
\hline PA 240 & $24^{\circ} 16^{\prime} 27.38^{\prime \prime S}$ & $65^{\circ} 50^{\prime} 55.22^{\prime \prime} \mathrm{O}$ \\
\hline PA 241 & $24^{\circ} 16^{\prime} 9.55^{\prime \prime S}$ & $65^{\circ} 50^{\prime} 55.43^{\prime \prime} \mathrm{O}$ \\
\hline PA 242 & $24^{\circ} 16^{\prime} 12.60^{\prime \prime S}$ & $65^{\circ} 51^{\prime} 3.19^{\prime \prime O}$ \\
\hline
\end{tabular}


"O Sistema Magmático do Depósito de Cu-Mo Tipo Pórfiro Pancho Árias, Cordilheira Oriental, Argentina" Rafael Bellozupko Stremel

Anexo 2 - TABELA DE ANÁLISE DE QUÍMICA MINERAL DOS PLAGIOCLÁSIOS

\begin{tabular}{|c|c|c|c|c|c|c|c|c|c|c|c|c|c|c|c|c|c|}
\hline Amostra & $\mathrm{Na}_{2} \mathrm{O}$ & $\mathrm{MgO}$ & $\mathrm{F}$ & $\mathrm{Al}_{2} \mathrm{O}_{3}$ & $\mathrm{SiO}_{2}$ & $\mathrm{CaO}$ & $\mathrm{K}_{2} \mathrm{O}$ & $\mathrm{Cl}$ & $\mathrm{P}_{2} \mathrm{O}_{5}$ & $\mathrm{TiO}_{2}$ & $\mathrm{Cr}_{2} \mathrm{O}_{3}$ & $\mathrm{MnO}$ & $\mathrm{NiO}$ & $\mathrm{FeO}$ & $\mathrm{V}_{2} \mathrm{O}_{3}$ & $(\mathrm{OH})$ & Total \\
\hline PA237_C1P1 1 & 7,36 & 0,00 & 0,00 & 24,88 & 59,77 & 6,60 & 0,29 & 0,01 & 0,00 & 0,10 & 0,00 & 0,00 & 0,01 & 0,13 & 0,00 & 0,85 & 100,0 \\
\hline PA237_C1Pl 2 & 6,89 & 0,00 & 0,00 & 25,39 & 58,69 & 7,03 & 0,37 & 0,00 & 0,04 & 0,00 & 0,00 & 0,03 & 0,00 & 0,15 & 0,07 & 1,34 & 100,0 \\
\hline PA237_C1P1 3 & 7,26 & 0,00 & 0,00 & 24,98 & 59,82 & 6,66 & 0,31 & 0,00 & 0,02 & 0,00 & 0,09 & 0,00 & 0,00 & 0,18 & 0,01 & 0,66 & 100,0 \\
\hline PA237_C1Pl 4 & 0,10 & 0,05 & 0,65 & 35,29 & 45,45 & 0,07 & 0,12 & 0,16 & 0,05 & 0,11 & 0,15 & 0,00 & 0,00 & 0,79 & 0,03 & 17,30 & 100,0 \\
\hline PA237_C1P1 5 & 7,66 & 0,02 & 0,00 & 24,24 & 60,06 & 6,09 & 0,37 & 0,00 & 0,00 & 0,05 & 0,00 & 0,03 & 0,00 & 0,08 & 0,00 & 1,41 & 100,0 \\
\hline PA102_C4pl b1 & 5,24 & 0,02 & 0,00 & 27,32 & 54,52 & 10,05 & 0,52 & 0,00 & 0,00 & 0,00 & 0,00 & 0,02 & 0,04 & 0,19 & 0,02 & 2,06 & 100,0 \\
\hline PA102_C4pl b2 & 3,07 & 0,02 & 0,00 & 31,01 & 48,73 & 14,47 & 0,12 & 0,01 & 0,00 & 0,23 & 0,00 & 0,02 & 0,06 & 0,59 & 0,04 & 1,64 & 100,0 \\
\hline PA101AC9 pl 1 & 6,90 & 0,00 & 0,00 & 25,06 & 58,47 & 7,06 & 0,32 & 0,02 & 0,00 & 0,00 & 0,10 & & 0,00 & 0,03 & 0,01 & 2,01 & 100,0 \\
\hline PA221_C2 pl 1 & 7,02 & 0,00 & 0,00 & 25,68 & 56,95 & 7,90 & 0,37 & 0,01 & & & & & & 0,26 & 0,02 & 1,48 & 100,0 \\
\hline PA221_C2 pl 2 & 6,34 & 0,01 & 0,00 & 26,71 & 55,66 & 8,96 & 0,42 & 0,02 & 0,00 & 0,00 & 0,03 & 0,00 & 0,02 & 0,19 & 0,02 & 1,64 & 100,0 \\
\hline PA221_C1 pl 1 & 6,92 & 0,02 & 0,00 & 25,97 & 57,75 & 7,76 & 0,32 & 0,00 & 0,06 & 0,06 & 0,00 & 0,02 & 0,00 & 0,20 & 0,00 & 0,90 & 100,0 \\
\hline PA221_C1 pl 2 & 6,52 & 0,00 & 0,00 & 25,40 & 57,81 & 7,95 & 0,60 & 0,01 & 0,05 & 0,00 & 0,00 & 0,07 & 0,00 & 0,20 & 0,00 & 1,39 & 100,0 \\
\hline PA221_C1 pl 3 & 5,64 & 0,01 & 0,00 & 27,67 & 55,06 & 9,97 & 0,33 & 0,01 & 0,03 & 0,00 & 0,00 & 0,02 & 0,01 & 0,19 & 0,04 & 1,04 & 100,0 \\
\hline PA221_C1 pl 4 & 6,96 & 0,00 & 0,00 & 25,51 & 57,57 & 7,96 & 0,42 & 0,01 & 0,00 & 0,00 & 0,00 & 0,06 & 0,00 & 0,17 & 0,02 & 1,33 & 100,0 \\
\hline PA220_C7pl 1 & 6,21 & 0,02 & 0,00 & 25,98 & 58,73 & 7,63 & 0,80 & 0,00 & 0,03 & 0,19 & 0,00 & 0,07 & 0,00 & 0,08 & 0,00 & 0,26 & 100,0 \\
\hline PA220_C7pl 2 & 6,19 & 0,05 & 0,00 & 25,76 & 58,67 & 8,11 & 0,80 & 0,01 & 0,00 & 0,04 & 0,08 & 0,05 & 0,00 & 0,18 & 0,03 & 0,04 & 100,0 \\
\hline PA201_C7P1 1 & 6,95 & 0,01 & 0,00 & 25,18 & 59,33 & 7,21 & 0,46 & 0,01 & 0,03 & 0,00 & 0,00 & 0,06 & 0,00 & 0,19 & 0,00 & 0,58 & 100,0 \\
\hline PA201_C7P1 2 & 6,70 & 0,00 & 0,00 & 25,90 & 58,33 & 8,23 & 0,48 & 0,02 & 0,00 & 0,00 & 0,01 & 0,11 & 0,00 & 0,26 & 0,00 & 0,00 & 100,0 \\
\hline PA201_C7P1 3 & 6,71 & 0,00 & 0,00 & 25,39 & 59,08 & 7,65 & 0,57 & 0,00 & 0,01 & 0,00 & 0,08 & 0,06 & 0,00 & 0,28 & 0,04 & 0,15 & 100,0 \\
\hline PA201_C7Pl 4 & 5,94 & 0,04 & 0,00 & 26,98 & 57,84 & 8,88 & 0,36 & 0,00 & 0,00 & 0,11 & 0,00 & 0,08 & 0,07 & 0,23 & 0,01 & 0,00 & 100,5 \\
\hline PA201_C7P1 5 & 6,40 & 0,00 & 0,00 & 26,06 & 58,00 & 8,20 & 0,40 & 0,00 & 0,01 & 0,00 & 0,01 & 0,00 & 0,05 & 0,30 & 0,02 & 0,55 & 100,0 \\
\hline PA201_C7P1 6 & 6,97 & 0,06 & 0,00 & 25,64 & 59,30 & 7,43 & 0,46 & 0,00 & 0,00 & 0,03 & 0,00 & 0,03 & 0,02 & 0,13 & 0,03 & 0,00 & 100,1 \\
\hline PA201_C7P1 7 & 2,96 & 0,01 & 0,00 & 19,64 & 63,95 & 1,14 & 11,57 & 0,00 & 0,00 & 0,30 & 0,06 & 0,00 & 0,02 & 0,09 & 0,03 & 0,23 & 100,0 \\
\hline
\end{tabular}


"O Sistema Magmático do Depósito de Cu-Mo Tipo Pórfiro Pancho Árias, Cordilheira Oriental, Argentina" Rafael Bellozupko Stremel

\begin{tabular}{|c|c|c|c|c|c|c|c|c|c|c|c|c|c|}
\hline Amostra & $\mathrm{Si}$ & $\mathrm{Ti}$ & $\mathrm{Al}$ & $\mathrm{Fe}^{3+}$ & $\mathrm{Fe}^{2+}$ & $\mathrm{Ca}$ & $\mathrm{Na}$ & $\mathrm{K}$ & tot. cat. & tot. oxy. & An $\%$ & $\mathrm{Ab} \%$ & Or\% \\
\hline PA-237_C1_Pl 1 & 2,68 & 0,00 & 1,32 & 0,00 & 0,00 & 0,32 & 0,64 & 0,02 & 4,98 & 8,00 & 32,57 & 65,70 & 1,73 \\
\hline PA-237_C1_Pl 2 & 2,65 & 0,00 & 1,35 & 0,00 & 0,00 & 0,34 & 0,60 & 0,02 & 4,98 & 8,00 & 35,25 & 62,52 & 2,23 \\
\hline PA-237_C1_Pl 3 & 2,68 & 0,00 & 1,32 & 0,00 & 0,00 & 0,32 & 0,63 & 0,02 & 4,98 & 8,00 & 33,01 & 65,13 & 1,85 \\
\hline PA-237_C1_Pl 4 & 2,35 & 0,00 & 2,15 & 0,02 & 0,01 & 0,00 & 0,01 & 0,01 & 4,57 & 8,00 & 18,31 & 46,75 & 34,94 \\
\hline PA-237_C1_Pl 5 & 2,71 & 0,00 & 1,29 & 0,00 & 0,00 & 0,29 & 0,67 & 0,02 & 4,99 & 8,00 & 29,85 & 67,98 & 2,17 \\
\hline PA-102_C4_pl b1 & 2,51 & 0,00 & 1,48 & 0,00 & 0,00 & 0,50 & 0,47 & 0,03 & 5,00 & 8,00 & 49,84 & 47,06 & 3,10 \\
\hline PA-102_C4_pl b2 & 2,27 & 0,01 & 1,70 & 0,01 & 0,01 & 0,72 & 0,28 & 0,01 & 5,01 & 8,00 & 71,71 & 27,56 & 0,73 \\
\hline PA-101A_C9 pl 1 & 2,66 & 0,00 & 1,34 & 0,00 & 0,00 & 0,34 & 0,61 & 0,02 & 4,98 & 8,00 & 35,43 & 62,66 & 1,91 \\
\hline PA-221_C2 pl 1 & 2,60 & 0,01 & 1,38 & 0,01 & 0,00 & 0,39 & 0,62 & 0,02 & 5,02 & 8,00 & 37,57 & 60,36 & 2,07 \\
\hline PA-221_C2 pl 2 & 2,55 & 0,00 & 1,44 & 0,00 & 0,00 & 0,44 & 0,56 & 0,02 & 5,02 & 8,00 & 42,82 & 54,79 & 2,38 \\
\hline PA-221_C1 pl 1 & 2,61 & 0,00 & 1,38 & 0,00 & 0,00 & 0,38 & 0,61 & 0,02 & 5,00 & 8,00 & 37,55 & 60,62 & 1,83 \\
\hline PA-221_C1 pl 2 & 2,63 & 0,00 & 1,36 & 0,00 & 0,00 & 0,39 & 0,57 & 0,03 & 4,99 & 8,00 & 38,84 & 57,65 & 3,51 \\
\hline PA-221_C1 pl 3 & 2,51 & 0,00 & 1,48 & 0,00 & 0,00 & 0,49 & 0,50 & 0,02 & 5,00 & 8,00 & 48,49 & 49,62 & 1,89 \\
\hline PA-221_C1 pl 4 & 2,62 & 0,00 & 1,37 & 0,00 & 0,00 & 0,39 & 0,61 & 0,02 & 5,02 & 8,00 & 37,80 & 59,84 & 2,36 \\
\hline PA-220_C7_pl 1 & 2,63 & 0,01 & 1,37 & 0,00 & 0,00 & 0,37 & 0,54 & 0,05 & 4,97 & 8,00 & 38,49 & 56,68 & 4,83 \\
\hline PA-220_C7_pl 2 & 2,63 & 0,00 & 1,36 & 0,00 & 0,00 & 0,39 & 0,54 & 0,05 & 4,98 & 8,00 & 40,00 & 55,28 & 4,72 \\
\hline PA-201_C7_Pl 1 & 2,66 & 0,00 & 1,33 & 0,00 & 0,00 & 0,35 & 0,60 & 0,03 & 4,98 & 8,00 & 35,46 & 61,86 & 2,69 \\
\hline PA-201_C7_Pl 2 & 1,00 & 0,00 & 1,37 & 0,01 & 0,00 & 0,40 & 0,58 & 0,03 & 5,00 & 8,00 & 39,31 & 57,95 & 2,74 \\
\hline PA-201_C7_Pl 3 & 2,65 & 0,00 & 1,34 & 0,01 & 0,00 & 0,37 & 0,58 & 0,03 & 4,99 & 8,00 & 37,37 & 59,34 & 3,29 \\
\hline PA-201_C7_Pl 4 & 2,58 & 0,00 & 1,42 & 0,01 & 0,00 & 0,42 & 0,51 & 0,02 & 4,97 & 8,00 & 44,28 & 53,57 & 2,16 \\
\hline PA-201_C7_Pl 5 & 2,61 & 0,00 & 1,38 & 0,01 & 0,00 & 0,40 & 0,56 & 0,02 & 4,98 & 8,00 & 40,48 & 57,17 & 2,34 \\
\hline PA-201_C7_Pl 6 & 2,65 & 0,00 & 1,35 & 0,00 & 0,00 & 0,36 & 0,60 & 0,03 & 4,99 & 8,00 & 36,08 & 61,25 & 2,67 \\
\hline PA-201_C7_P1 7 & 2,93 & 0,01 & 1,06 & 0,00 & 0,00 & 0,06 & 0,26 & 0,68 & 5,00 & 8,00 & 5,63 & 26,41 & 67,96 \\
\hline
\end{tabular}

Anexo 3 - TABELA DE ANÁLISE DE QUÍMICA MINERAL DOS CARBONATOS

\begin{tabular}{|c|c|c|c|c|c|c|c|c|c|c|c|c|c|c|c|c|c|}
\hline Amostra & $\mathrm{Na}_{2} \mathrm{O}$ & $\mathrm{MgO}$ & $\mathrm{F}$ & $\mathrm{Al}_{2} \mathrm{O}_{3}$ & $\mathrm{SiO}_{2}$ & $\mathrm{CaO}$ & $\mathrm{K}_{2} \mathrm{O}$ & $\mathrm{Cl}$ & $\mathrm{P}_{2} \mathrm{O}_{5}$ & $\mathrm{TiO} 2$ & $\mathrm{Cr}_{2} \mathrm{O}_{3}$ & $\mathrm{MnO}$ & $\mathrm{NiO}$ & $\mathrm{FeO}$ & $\mathrm{V}_{2} \mathrm{O}_{3}$ & $(\mathrm{OH})$ & Total \\
\hline PA220C8carb 1 & 0,00 & 0,04 & 0,0 & 0,00 & 0,05 & 62,35 & 0,01 & 0,00 & 0,07 & 0,00 & 0,00 & 0,68 & 0,03 & 0,32 & 0,06 & 36,40 & 100,0 \\
\hline PA220C3Carb1 & 0,01 & 0,10 & 0,0 & 0,02 & 0,00 & 63,86 & 0,00 & 0,00 & 0,11 & 0,10 & 0,08 & 0,72 & 0,00 & 0,59 & 0,02 & 34,39 & 100,0 \\
\hline PA220C2Carb1 & 0,04 & 0,02 & 0,0 & 0,02 & 0,01 & 62,44 & 0,01 & 0,02 & 0,01 & 0,00 & 0,00 & 0,50 & 0,01 & 0,35 & 0,00 & 36,58 & 100,0 \\
\hline PA220 C1Carb1 & 0,00 & 0,10 & 0,0 & 0,00 & 0,02 & 63,14 & 0,00 & 0,00 & 0,00 & 0,00 & 0,04 & 0,77 & 0,00 & 0,33 & 0,02 & 35,59 & 100,0 \\
\hline
\end{tabular}

Anexo 4 - TABELA DE ANÁLISE DE QUÍMICA MINERAL DAS MICAS BRANCAS

\begin{tabular}{|c|c|c|c|c|c|c|c|c|c|c|c|c|c|c|c|c|c|}
\hline Amostra & $\mathrm{Na}_{2} \mathrm{O}$ & $\mathrm{MgO}$ & $\mathrm{F}$ & $\mathrm{Al}_{2} \mathrm{O}_{3}$ & $\mathrm{SiO}_{2}$ & $\mathrm{CaO}$ & $\mathrm{K}_{2} \mathrm{O}$ & $\mathrm{Cl}$ & $\mathrm{P}_{2} \mathrm{O}_{5}$ & $\mathrm{TiO}_{2}$ & $\mathrm{Cr}_{2} \mathrm{O}_{3}$ & $\mathrm{MnO}$ & $\mathrm{NiO}$ & $\mathrm{FeO}$ & $\mathrm{V}_{2} \mathrm{O}_{3}$ & $(\mathrm{OH})$ & Total \\
\hline PA213_C2mb1 & 0,15 & 2,54 & 0 & 29,75 & 47,27 & 0,00 & 10,88 & 0,01 & 0,00 & 0,42 & 0,01 & 0,01 & 0,01 & 4,56 & 0,07 & 4,30 & 100,0 \\
\hline PA213_C3mb1 & 0,47 & 0,55 & 0 & 33,84 & 45,91 & 0,02 & 10,69 & 0,02 & 0,05 & 0,73 & 0,03 & 0,00 & 0,02 & 3,29 & 0,03 & 4,34 & 100,0 \\
\hline PA213_C3mb2 & 0,42 & 0,63 & 0 & 33,93 & 45,80 & 0,00 & 10,63 & 0,0 & 0,00 & 0,64 & 0,00 & 0,05 & 0,00 & 3,22 & 0,01 & 4,67 & 100,0 \\
\hline PA220_C7mb1 & 6,18 & 0,05 & 0 & 26,44 & 57,93 & 7,97 & 0,96 & 0,0 & 0,01 & 0,00 & 0,07 & 0,00 & 0,00 & 0,26 & 0,00 & 0,13 & 100,0 \\
\hline
\end{tabular}

Anexo 5 - TABELA DE ANÁLISE DE QUÍMICA MINERAL DAS MOLIBDENITAS

\begin{tabular}{|c|rrrrrrrrrrrrrr}
\hline Amostra & $\mathrm{Ag}$ & $\mathrm{Pb}$ & $\mathrm{Bi}$ & $\mathrm{Fe}$ & $\mathrm{Mo}$ & $\mathrm{Cu}$ & $\mathrm{Zn}$ & $\mathrm{Cd}$ & $\mathrm{Au}$ & $\mathrm{Co}$ & $\mathrm{Ni}$ & $\mathrm{S}$ & $\mathrm{Total}$ \\
\hline PA218A_C1mob 1 & 0,00 & 0,00 & 0,28 & 0,02 & 58,49 & 0,00 & 0,02 & 0,00 & 0,56 & 0,02 & 0,00 & 39,83 & 99,25 \\
PA218A_C1mob 2 & 0,00 & 0,00 & 0,02 & 0,05 & 59,12 & 0,00 & 0,04 & 0,00 & 0,52 & 0,00 & 0,00 & 39,88 & 99,63 \\
\hline
\end{tabular}


"O Sistema Magmático do Depósito de Cu-Mo Tipo Pórfiro Pancho Árias, Cordilheira Oriental, Argentina"

Rafael Bellozupko Stremel

\section{Anexo 6 - TABELA DE ANÁLISE DE QUÍMICA MINERAL DOS ANFIBÓLIOS}

\begin{tabular}{|c|c|c|c|c|c|c|c|c|c|c|c|c|c|c|c|c|c|}
\hline Amostra & $\mathrm{Na}_{2} \mathrm{O}$ & $\mathrm{MgO}$ & $\mathrm{F}$ & $\mathrm{Al}_{2} \mathrm{O}_{3}$ & $\mathrm{SiO}_{2}$ & $\mathrm{CaO}$ & $\mathrm{K}_{2} \mathrm{O}$ & $\mathrm{Cl}$ & $\mathrm{P}_{2} \mathrm{O}_{5}$ & $\mathrm{TiO}_{2}$ & $\mathrm{Cr}_{2} \mathrm{O}_{3}$ & $\mathrm{MnO}$ & $\mathrm{NiO}$ & $\mathrm{FeO}$ & $\mathrm{V}_{2} \mathrm{O}_{3}$ & $(\mathrm{OH})$ & Total \\
\hline PA201C1Anf 1 & 0,87 & 15,15 & 0,0 & 4,77 & 49,98 & 11,71 & 0,45 & 0,08 & 0,01 & 0,98 & 0,00 & 0,70 & 0,00 & 13,14 & 0,05 & 2,12 & 100,0 \\
\hline PA201C4Anf 1 & 0,86 & 15,64 & 0,19 & 4,80 & 50,89 & 11,59 & 0,41 & 0,09 & 0,00 & 0,90 & 0,06 & 0,71 & 0,00 & 12,97 & 0,04 & 0,95 & 100,0 \\
\hline PA201C4Anf 2 & 0,98 & 14,54 & 0,17 & 5,89 & 48,85 & 11,25 & 0,61 & 0,09 & 0,03 & 1,09 & 0,00 & 0,93 & 0,05 & 13,94 & 0,00 & 1,68 & 100,0 \\
\hline PA201C8Anf 1 & 0,99 & 14,83 & 0,0 & 5,64 & 49,54 & 11,62 & 0,56 & 0,09 & 0,00 & 0,97 & 0,02 & 0,79 & 0,00 & 13,48 & 0,06 & 1,43 & 100,0 \\
\hline PA201C8Anf 2 & 0,86 & 15,40 & 0,06 & 5,39 & 50,04 & 11,50 & 0,51 & 0,05 & 0,03 & 0,76 & 0,11 & 0,87 & 0,03 & 12,99 & 0,06 & 1,40 & 100,0 \\
\hline PA201C10Anf & 0,69 & 15,34 & 0,12 & 4,68 & 50,61 & 11,89 & 0,44 & 0,07 & 0,00 & 0,70 & 0,09 & 0,69 & 0,00 & 13,07 & 0,06 & 1,63 & 100,0 \\
\hline PA201C1Chl 2 & 1,00 & 13,69 & 0,15 & 7,23 & 47,03 & 11,35 & 0,74 & 0,09 & 0,00 & 1,37 & 0,05 & 0,70 & 0,05 & 14,51 & 0,09 & 2,05 & 100,0 \\
\hline PA201C4Chl 1 & 0,98 & 14,51 & 0,06 & 5,68 & 48,97 & 11,48 & 0,51 & 0,08 & 0,04 & 0,91 & 0,00 & 0,84 & 0,03 & 13,49 & 0,02 & 2,44 & 100,0 \\
\hline PA221C3 hbl 1 & 0,55 & 15,55 & 0,03 & 3,86 & 50,34 & 12,08 & 0,28 & 0,13 & 0,00 & 0,55 & 0,12 & 0,62 & 0,00 & 12,52 & 0,00 & 3,41 & 100,0 \\
\hline
\end{tabular}

\begin{tabular}{|c|c|c|c|c|c|c|c|c|c|c|c|c|c|c|}
\hline Amostra & $\mathrm{Si}$ & $\mathrm{Al}^{\text {iv }}$ & $\mathrm{Al}^{\mathrm{vi}}$ & $\mathrm{Ti}$ & $\mathrm{Cr}$ & $\mathrm{Fe}^{3+}$ & $\mathrm{Fe}^{2+}$ & $\mathrm{Mn}$ & $\mathrm{Mg}$ & $\mathrm{Ni}$ & $\mathrm{Ca}$ & $\mathrm{Na}$ & $\mathrm{K}$ & $\left(\mathrm{Mg} / \mathrm{Mg}+\mathrm{Fe}^{2+}\right)$ \\
\hline PA-221_C3 hbl 1 & 7,306 & 0,661 & 0,000 & 0,059 & 0,014 & 0,631 & 0,888 & 0,076 & 3,365 & 0,000 & 1,878 & 0,156 & 0,052 & 0,791 \\
\hline PA-201_C1_Anf 1 & 7,179 & 0,807 & 0,000 & 0,106 & 0,000 & 0,692 & 0,886 & 0,085 & 3,244 & 0,000 & 1,803 & 0,243 & 0,082 & 0,785 \\
\hline PA-201_C4_Anf 1 & 7,188 & 0,800 & 0,000 & 0,095 & 0,007 & 0,810 & 0,722 & 0,085 & 3,293 & 0,000 & 1,754 & 0,235 & 0,074 & 0,820 \\
\hline PA-201_C4_Anf 2 & 6,996 & 0,994 & 0,000 & 0,118 & 0,000 & 0,942 & 0,727 & 0,112 & 3,105 & 0,006 & 1,726 & 0,273 & 0,112 & 0,810 \\
\hline PA-201_C8_Anf 1 & 7,078 & 0,922 & 0,027 & 0,104 & 0,002 & 0,749 & 0,862 & 0,096 & 3,159 & 0,000 & 1,779 & 0,274 & 0,102 & 0,786 \\
\hline PA-201_C8_Anf 2 & 7,099 & 0,901 & 0,001 & 0,081 & 0,012 & 0,902 & 0,640 & 0,104 & 3,256 & 0,003 & 1,748 & 0,237 & 0,092 & 0,836 \\
\hline PA-201_C10_Anf 1 & 7,222 & 0,778 & 0,008 & 0,075 & 0,010 & 0,705 & 0,855 & 0,083 & 3,264 & 0,000 & 1,817 & 0,191 & 0,080 & 0,792 \\
\hline
\end{tabular}

\section{Anexo 7 - TABELA DE ANÁLISE DE QUÍMICA MINERAL DAS CLORITAS}

\begin{tabular}{|c|c|c|c|c|c|c|c|c|c|c|c|c|c|c|c|c|c|}
\hline Amostra & $\mathrm{Na}_{2} \mathrm{O}$ & $\mathrm{MgO}$ & $\mathrm{F}$ & $\mathrm{Al}_{2} \mathrm{O}_{3}$ & $\mathrm{SiO}_{2}$ & $\mathrm{CaO}$ & $\mathrm{K}_{2} \mathrm{O}$ & $\mathrm{Cl}$ & $\mathrm{P}_{2} \mathrm{O}_{5}$ & $\mathrm{TiO}_{2}$ & $\mathrm{Cr}_{2} \mathrm{O}_{3}$ & $\mathrm{MnO}$ & $\mathrm{NiO}$ & $\mathrm{FeO}$ & $\mathrm{V}_{2} \mathrm{O}_{3}$ & $(\mathrm{OH})$ & Total \\
\hline PA221 C3 chl1 & 0,00 & 18,52 & 0,02 & 19,83 & 26,65 & 0,04 & 0,01 & 0,00 & 0,00 & 0,05 & 0,00 & 0,85 & 0,00 & 23,04 & 0,06 & 10,93 & 100 \\
\hline PA220 C8 chl1 & 0,00 & 13,94 & 0,06 & 19,78 & 26,02 & 0,02 & 0,05 & 0,01 & 0,00 & 0,00 & 0,00 & 0,45 & 0,02 & 29,87 & 0,04 & 9,78 & 100 \\
\hline PA220 C8 chl2 & 0,00 & 0,00 & 1,45 & 3,35 & 30,87 & 28,44 & 0,02 & 0,00 & 0,00 & 34,33 & 0,05 & 0,00 & 0,02 & 1,09 & 0,44 & 0,55 & 100 \\
\hline PA220 C8 chl3 & 0,04 & 15,16 & 0,30 & 18,76 & 26,78 & 0,03 & 0,03 & 0,02 & 0,02 & 0,00 & 0,00 & 0,49 & 0,05 & 29,08 & 0,03 & 9,37 & 100 \\
\hline PA220 C5 ch12 & 0,03 & 14,21 & 0,19 & 19,49 & 26,86 & 0,07 & 0,03 & 0,03 & 0,00 & 0,08 & 0,01 & 0,45 & 0,01 & 29,57 & 0,02 & 9,04 & 100 \\
\hline PA220 C6 chl1 & 0,00 & 14,37 & 0,16 & 19,28 & 26,62 & 0,04 & 0,12 & 0,01 & 0,03 & 0,22 & 0,11 & 0,34 & 0,03 & 29,18 & 0,08 & 9,49 & 100 \\
\hline PA220 C4 chl1 & 0,06 & 14,52 & 0,06 & 18,90 & 26,36 & 0,00 & 0,01 & 0,02 & 0,00 & 0,29 & 0,08 & 0,44 & 0,04 & 29,76 & 0,11 & 9,36 & 100 \\
\hline PA220 C4 chl2 & 0,00 & 14,09 & 0,14 & 20,00 & 26,33 & 0,03 & 0,03 & 0,00 & 0,02 & 0,13 & 0,00 & 0,46 & 0,00 & 29,57 & 0,06 & 9,19 & 100 \\
\hline PA220 C 3 chl1 & 0,03 & 14,77 & 0,23 & 18,32 & 26,58 & 0,12 & 0,01 & 0,03 & 0,00 & 0,09 & 0,09 & 0,47 & 0,00 & 29,62 & 0,04 & 9,72 & 100 \\
\hline PA220 C 3 chl2 & 0,00 & 0,02 & 2,94 & 6,49 & 31,39 & 28,91 & 0,01 & 0,00 & 0,00 & 27,74 & 0,06 & 0,00 & 0,00 & 1,50 & 0,38 & 1,79 & 100 \\
\hline PA220 C 2 chl1 & 0,00 & 14,52 & 0,24 & 18,58 & 26,62 & 0,12 & 0,22 & 0,00 & 0,00 & 0,00 & 0,00 & 0,50 & 0,03 & 29,19 & 0,06 & 10,03 & 100 \\
\hline PA220 C 2 chl2 & 0,01 & 14,12 & 0,19 & 18,63 & 26,89 & 0,03 & 0,04 & 0,01 & 0,01 & 0,16 & 0,00 & 0,47 & 0,02 & 30,11 & 0,03 & 9,40 & 100 \\
\hline PA220 C1 chl1 & 0,03 & 14,08 & 0,17 & 18,64 & 26,62 & 0,52 & 0,13 & 0,02 & 0,06 & 0,00 & 0,02 & 0,40 & 0,00 & 28,70 & 0,05 & 10,64 & 100 \\
\hline PA220 C 1 chl2 & 0,06 & 0,03 & 0,59 & 2,09 & 29,92 & 27,72 & 0,00 & 0,00 & 0,00 & 36,16 & 0,00 & 0,07 & 0,03 & 0,80 & 0,51 & 2,28 & 100 \\
\hline PA201 C1 chl1 & 0,02 & 18,44 & 0,05 & 18,58 & 27,79 & 0,08 & 0,05 & 0,00 & 0,00 & 0,00 & 0,00 & 1,05 & 0,00 & 23,49 & 0,02 & 10,47 & 100 \\
\hline PA201 C1 chl2 & 1,00 & 13,69 & 0,15 & 7,23 & 47,03 & 11,35 & 0,74 & 0,09 & 0,00 & 1,37 & 0,05 & 0,70 & 0,05 & 14,51 & 0,09 & 2,05 & 100 \\
\hline PA201 C4 chl1 & 0,98 & 14,51 & 0,06 & 5,68 & 48,97 & 11,48 & 0,51 & 0,08 & 0,04 & 0,91 & 0,00 & 0,84 & 0,03 & 13,49 & 0,02 & 2,44 & 100 \\
\hline PA201 C6 chl1 & 0,04 & 14,57 & 0,22 & 15,18 & 29,94 & 3,27 & 0,21 & 0,01 & 0,04 & 3,96 & 0,01 & 0,77 & 0,00 & 21,67 & 0,11 & 10,10 & 100 \\
\hline PA201 C8 chl1 & 0,04 & 17,95 & 0,04 & 17,45 & 28,01 & 0,32 & 0,01 & 0,00 & 0,00 & 0,58 & 0,04 & 0,65 & 0,00 & 23,49 & 0,04 & 11,42 & 100 \\
\hline PA201C10chl1 & 0,01 & 18,19 & 0,13 & 19,44 & 27,51 & 0,06 & 0,01 & 0,00 & 0,00 & 0,03 & 0,00 & 1,00 & 0,00 & 23,54 & 0,00 & 10,13 & 100 \\
\hline
\end{tabular}


"O Sistema Magmático do Depósito de Cu-Mo Tipo Pórfiro Pancho Árias, Cordilheira Oriental, Argentina" Rafael Bellozupko Stremel

\begin{tabular}{|c|c|c|c|c|c|c|c|c|c|c|c|c|c|c|c|c|}
\hline Amostra & $\mathrm{Si}$ & $\mathrm{Al}^{\text {iv }}$ & $\mathrm{Al}^{\mathrm{vi}}$ & $\mathrm{Ti}$ & $\mathrm{Fe}^{2+}$ & $\mathrm{Mn}$ & $\mathrm{Mg}$ & $\mathrm{Ni}$ & $\mathrm{Ca}$ & $\mathrm{Na}$ & $\mathrm{K}$ & $\mathrm{F}$ & $\mathrm{Cl}$ & $\mathrm{OH}^{*}$ & Total & $\mathrm{Fe} / \mathrm{Fe}+\mathrm{Mg}$ \\
\hline PA-221_C3 chl 1 & 5,46 & 2,54 & 2,27 & 0,01 & 4,05 & 0,15 & 5,66 & 0,00 & 0,01 & 0,00 & 0,00 & 0,02 & 0,00 & 15,98 & 36,14 & 0,42 \\
\hline PA-220_C8_chl 1 & 5,45 & 2,55 & 2,34 & 0,00 & 5,30 & 0,08 & 4,35 & 0,00 & 0,00 & 0,00 & 0,03 & 0,07 & 0,01 & 15,92 & 36,10 & 0,55 \\
\hline PA-220_C5_chl 2 & 5,55 & 2,45 & 2,32 & 0,01 & 5,09 & 0,08 & 4,38 & 0,00 & 0,02 & 0,02 & 0,02 & 0,24 & 0,02 & 15,74 & 35,95 & 0,54 \\
\hline PA-220_C6_chl 1 & 5,54 & 2,46 & 2,27 & 0,03 & 5,08 & 0,06 & 4,46 & 0,01 & 0,01 & 0,00 & 0,06 & 0,21 & 0,00 & 15,78 & 35,99 & 0,53 \\
\hline PA-220_C4_chl 1 & 5,49 & 2,51 & 2,15 & 0,05 & 5,28 & 0,08 & 4,51 & 0,01 & 0,00 & 0,05 & 0,01 & 0,07 & 0,01 & 15,91 & 36,14 & 0,54 \\
\hline PA-220_C4_chl 2 & 5,46 & 2,54 & 2,37 & 0,02 & 5,14 & 0,08 & 4,36 & 0,00 & 0,01 & 0,00 & 0,02 & 0,19 & 0,00 & 15,81 & 35,99 & 0,54 \\
\hline PA-220_C3_Chl 1 & 5,54 & 2,46 & 2,07 & 0,01 & 5,23 & 0,08 & 4,59 & 0,00 & 0,03 & 0,03 & 0,01 & 0,31 & 0,02 & 15,67 & 36,06 & 0,53 \\
\hline PA-220_C2_Chl 1 & 5,56 & 2,44 & 2,16 & 0,00 & 5,16 & 0,09 & 4,52 & 0,01 & 0,03 & 0,00 & 0,12 & 0,31 & 0,00 & 15,69 & 36,08 & 0,53 \\
\hline PA-220_C2_Chl 2 & 5,61 & 2,39 & 2,20 & 0,02 & 5,25 & 0,08 & 4,39 & 0,00 & 0,01 & 0,01 & 0,02 & 0,26 & 0,00 & 15,74 & 35,98 & 0,54 \\
\hline PA-220_C1_Chl 1 & 5,60 & 2,40 & 2,25 & 0,00 & 5,07 & 0,07 & 4,42 & 0,00 & 0,12 & 0,03 & 0,07 & 0,23 & 0,01 & 15,75 & 36,02 & 0,53 \\
\hline PA-220_C8_chl 3 & 5,54 & 2,46 & 2,13 & 0,00 & 5,07 & 0,09 & 4,67 & 0,01 & 0,01 & 0,03 & 0,01 & 0,40 & 0,01 & 15,59 & 36,02 & 0,52 \\
\hline PA-220_C8_chl 2 & 5,55 & 0,72 & 0,00 & 4,64 & 0,00 & 0,00 & 0,00 & 0,00 & 5,48 & 0,00 & 0,01 & 1,65 & 0,00 & 14,35 & 32,57 & 1,00 \\
\hline PA-220_C3_Chl 2 & 5,55 & 1,40 & 0,00 & 3,69 & 0,00 & 0,00 & 0,01 & 0,00 & 5,48 & 0,00 & 0,01 & 3,29 & 0,00 & 12,71 & 32,37 & 0,98 \\
\hline PA-220_C1_Chl 2 & 5,56 & 0,46 & 0,00 & 5,05 & 0,00 & 0,01 & 0,01 & 0,00 & 5,52 & 0,04 & 0,00 & 0,69 & 0,00 & 15,31 & 32,78 & 0,95 \\
\hline PA-201_C4_Chl 1 & 8,48 & 0,00 & 1,20 & 0,12 & 0,72 & 0,12 & 3,75 & 0,00 & 2,13 & 0,66 & 0,23 & 0,07 & 0,04 & 15,89 & 34,63 & 0,34 \\
\hline PA-201_C1_Chl 2 & 8,17 & 0,00 & 1,53 & 0,18 & 0,96 & 0,10 & 3,55 & 0,01 & 2,11 & 0,68 & 0,33 & 0,16 & 0,05 & 15,79 & 34,77 & 0,37 \\
\hline PA-201_C6_Chl 1 & 6,02 & 1,98 & 1,67 & 0,60 & 3,07 & 0,13 & 4,37 & 0,00 & 0,70 & 0,03 & 0,11 & 0,28 & 0,00 & 15,71 & 35,27 & 0,45 \\
\hline PA-201_C8_Chl 1 & 5,80 & 2,20 & 2,05 & 0,09 & 4,04 & 0,11 & 5,54 & 0,00 & 0,07 & 0,03 & 0,00 & 0,05 & 0,00 & 15,95 & 35,97 & 0,42 \\
\hline PA-201_C10_Chl 1 & 5,59 & 2,41 & 2,26 & 0,00 & 4,02 & 0,17 & 5,51 & 0,00 & 0,01 & 0,01 & 0,01 & 0,17 & 0,00 & 15,83 & 36,00 & 0,42 \\
\hline PA-201_C1_Chl 1 & 5,68 & 2,32 & 2,17 & 0,00 & 4,07 & 0,18 & 5,62 & 0,00 & 0,02 & 0,02 & 0,02 & 0,06 & 0,00 & 15,94 & 36,09 & 0,42 \\
\hline
\end{tabular}


"O Sistema Magmático do Depósito de Cu-Mo Tipo Pórfiro Pancho Árias, Cordilheira Oriental, Argentina" Rafael Bellozupko Stremel

Anexo 8 - TABELA DE ANÁLISE DE QUÍMICA MINERAL DAS CALCOPIRITAS

\begin{tabular}{|c|c|c|c|c|c|c|c|c|c|c|c|c|}
\hline Amostra & $\mathrm{Ag}$ & $\mathrm{Pb}$ & $\mathrm{Fe}$ & Mo & $\mathrm{Cu}$ & $\mathrm{Zn}$ & $\mathrm{Cd}$ & $\mathrm{Au}$ & $\mathrm{Co}$ & $\mathrm{Ni}$ & $S$ & Total \\
\hline PA101A C1 срy & 0,00 & 0,15 & 29,68 & 0,05 & 35,43 & 0,08 & 0,02 & 0,00 & 0,07 & 0,00 & 32,70 & 98,25 \\
\hline PA101A C1 cv & 0,04 & 0,10 & 0,14 & 0,00 & 79,28 & 0,08 & 0,00 & 0,00 & 0,01 & 0,00 & 19,99 & 99,75 \\
\hline PA101A C1 сру2 & 0,01 & 0,12 & 31,72 & 0,06 & 32,35 & 0,00 & 0,02 & 0,00 & 0,02 & 0,00 & 34,60 & 98,88 \\
\hline PA101A C5 сру1 & 0,02 & 0,13 & 29,55 & 0,05 & 34,90 & 0,03 & 0,00 & 0,00 & 0,08 & 0,00 & 31,55 & 96,30 \\
\hline PA101A C5 cv1 & 0,01 & 0,09 & 0,04 & 0,02 & 77,34 & 0,09 & 0,00 & 0,00 & 0,01 & 0,00 & 20,76 & 98,38 \\
\hline PA105B C6 сру1 & 0,02 & 0,14 & 37,73 & 0,05 & 24,26 & 0,14 & 0,04 & 0,00 & 0,01 & 0,00 & 34,25 & 96,72 \\
\hline PA218A C2 cv1 & 0,02 & 0,25 & 46,94 & 0,16 & 0,02 & 0,00 & 0,01 & 0,00 & 0,07 & 0,02 & 53,66 & 101,14 \\
\hline PA218A C2 cv2 & 0,00 & 0,08 & 24,80 & 0,08 & 0,04 & 0,06 & 0,00 & 0,00 & 0,02 & 0,00 & 24,89 & 49,96 \\
\hline PA218A C2 cpy1 & 0,02 & 0,21 & 46,78 & 0,11 & 0,00 & 0,00 & 0,00 & 0,00 & 0,05 & 0,03 & 53,98 & 101,18 \\
\hline PA217A C1 cpy1 & 0,01 & 0,19 & 30,74 & 0,03 & 34,07 & 0,00 & 0,00 & 0,01 & 0,04 & 0,00 & 34,64 & 99,75 \\
\hline PA217A C1 сру2 & 0,00 & 0,13 & 30,25 & 0,11 & 33,93 & 0,08 & 0,01 & 0,00 & 0,02 & 0,00 & 34,91 & 99,44 \\
\hline PA217A C2 сру1 & 0,02 & 0,14 & 29,80 & 0,08 & 33,32 & 0,09 & 0,00 & 0,00 & 0,00 & 0,03 & 33,15 & 96,62 \\
\hline PA217D C4 cpy1 & 0,04 & 0,01 & 30,98 & 0,06 & 33,89 & 0,01 & 0,02 & 0,00 & 0,03 & 0,00 & 34,87 & 99,98 \\
\hline PA217D C5 сру2 & 0,02 & 0,14 & 30,43 & 0,11 & 33,76 & 0,08 & 0,00 & 0,00 & 0,03 & 0,01 & 34,42 & 99,01 \\
\hline PA217D C5 сру1 & 0,00 & 0,08 & 30,61 & 0,03 & 34,66 & 0,09 & 0,00 & 0,00 & 0,02 & 0,00 & 34,18 & 99,69 \\
\hline PA217D C5 сру3 & 0,02 & 0,18 & 30,71 & 0,04 & 33,50 & 0,02 & 0,00 & 0,00 & 0,05 & 0,01 & 34,44 & 99,00 \\
\hline PA217D C1 срy1 & 0,04 & 0,18 & 29,93 & 0,00 & 31,42 & 0,50 & 0,05 & 0,00 & 0,00 & 0,01 & 32,72 & 94,91 \\
\hline PA217D C1 сру2 & 0,01 & 0,14 & 41,10 & 0,09 & 23,51 & 0,00 & 0,00 & 0,00 & 0,04 & 0,03 & 35,05 & 99,98 \\
\hline PA217D C3 сру1 & 0,01 & 0,20 & 30,91 & 0,06 & 33,56 & 0,13 & 0,00 & 0,00 & 0,01 & 0,00 & 34,67 & 99,55 \\
\hline PA 217D C3 сру2 & 0,00 & 0,16 & 47,66 & 0,11 & 0,04 & 0,00 & 0,00 & 0,00 & 0,04 & 0,07 & 52,94 & 101,03 \\
\hline PA235 C1 сру1 & 0,02 & 0,10 & 43,37 & 0,06 & 17,18 & 0,00 & 0,00 & 0,00 & 0,02 & 0,02 & 32,94 & 93,74 \\
\hline PA235 C1 сру2 & 0,01 & 0,06 & 30,69 & 0,11 & 33,35 & 0,00 & 0,00 & 0,00 & 0,01 & 0,00 & 34,65 & 98,99 \\
\hline PA235 C2 cpy1 & 0,01 & 0,08 & 30,24 & 0,15 & 34,54 & 0,07 & 0,00 & 0,00 & 0,04 & 0,00 & 35,67 & 100,84 \\
\hline PA235 C4 cv2 & 0,00 & 0,14 & 0,07 & 0,03 & 68,82 & 0,00 & 0,02 & 0,00 & 0,03 & 0,00 & 30,67 & 99,85 \\
\hline PA235 C4 сру1 & 0,04 & 0,09 & 0,11 & 0,00 & 76,94 & 0,00 & 0,00 & 0,00 & 0,00 & 0,00 & 23,81 & 100,99 \\
\hline PA235 C4 cv3 & 0,02 & 0,13 & 0,04 & 0,05 & 77,43 & 0,02 & 0,00 & 0,00 & 0,00 & 0,00 & 22,46 & 100,16 \\
\hline
\end{tabular}

\section{Anexo 9 - TABELA DE ANÁLISE DE QUÍMICA MINERAL DAS ILMENITAS}

\begin{tabular}{|c|cccccccccccccc|}
\hline Amostra & $\mathrm{Na}_{2} \mathrm{O}$ & $\mathrm{Al}_{2} \mathrm{O}$ & $\mathrm{SiO}_{2}$ & $\mathrm{CaO}$ & $\mathrm{K}_{2} \mathrm{O}$ & $\mathrm{P}_{2} \mathrm{O}_{5}$ & $\mathrm{TiO}_{2}$ & $\mathrm{Cr}_{2} \mathrm{O}$ & $\mathrm{MnO}$ & $\mathrm{NiO}$ & $\mathrm{FeO}$ & $\mathrm{V}_{2} \mathrm{O}_{3}$ & $\mathrm{OH}$ & $\mathrm{Total}$ \\
\hline PA235 C1 Il1 & 0,00 & 0,12 & 0,10 & 0,04 & 0,02 & 0,03 & 90,59 & 0,08 & 0,06 & 0,00 & 2,73 & 1,18 & 5,02 & 100,0 \\
PA235 C1 I12 & 0,00 & 0,09 & 0,08 & 0,02 & 0,02 & 0,02 & 93,87 & 0,15 & 0,10 & 0,08 & 2,27 & 1,16 & 2,14 & 100,0 \\
PA235 C1 Il3 & 0,05 & 0,08 & 0,05 & 0,03 & 0,00 & 0,03 & 99,78 & 0,06 & 0,00 & 0,00 & 1,17 & 0,91 & 0,00 & 102,2 \\
\hline PA217A C2 Il1 & 0,02 & 0,04 & 0,17 & 0,00 & 0,07 & 0,06 & 50,52 & 0,05 & 2,89 & 0,00 & 42,00 & 0,39 & 3,79 & 100,0 \\
PA217A C2 Il2 & 0,03 & 0,04 & 0,05 & 0,01 & 0,01 & 0,00 & 100,9 & 0,00 & 0,08 & 0,00 & 1,08 & 0,79 & 0,00 & 103,1 \\
\hline PA101A C1 ox1 & 0,03 & 0,72 & 1,30 & 0,06 & 0,07 & 0,02 & 74,77 & 0,02 & 0,36 & 0,03 & 15,49 & 1,12 & 5,95 & 100,0 \\
PA101A C2 Il & 0,00 & 0,01 & 0,02 & 0,01 & 0,06 & 0,02 & 93,67 & 0,03 & 0,00 & 0,00 & 2,03 & 0,97 & 3,18 & 100,0 \\
\hline PA218 C1 mg & 0,00 & 0,02 & 0,12 & 0,00 & 0,07 & 0,05 & 98,48 & 0,06 & 0,00 & 0,00 & 0,79 & 0,81 & 0,00 & 100,4 \\
\hline
\end{tabular}


"O Sistema Magmático do Depósito de Cu-Mo Tipo Pórfiro Pancho Árias, Cordilheira Oriental, Argentina"

Rafael Bellozupko Stremel

Anexo 10 - TABELA DE ANÁLISE DE QUÍMICA MINERAL DAS PIRITAS

\begin{tabular}{|c|c|c|c|c|c|c|c|c|c|c|c|c|c|}
\hline Amostra & $\mathrm{Ag}$ & $\mathrm{Pb}$ & $\mathrm{Bi}$ & $\mathrm{Fe}$ & Mo & $\mathrm{Cu}$ & $\mathrm{Zn}$ & $\mathrm{Cd}$ & $\mathrm{Au}$ & $\mathrm{Co}$ & $\mathrm{Ni}$ & $\mathrm{S}$ & Total \\
\hline PA-218_C1_Py & 0,03 & 0,07 & 0,00 & 46,41 & 0,14 & 0,01 & 0,00 & 0,05 & 0,00 & 0,05 & 0,00 & 52,54 & 99,31 \\
\hline PA-105 B_C6 py 1 & 0,00 & 0,23 & 0,00 & 46,46 & 0,10 & 0,00 & 0,00 & 0,00 & 0,00 & 0,10 & 0,04 & 53,37 & 100,38 \\
\hline PA-213_C2_py 1 & 0,03 & 0,11 & 0,00 & 46,82 & 0,13 & 0,07 & 0,04 & 0,00 & 0,00 & 0,06 & 0,01 & 54,11 & 101,37 \\
\hline PA-213_C3_py 1 & 0,00 & 0,22 & 0,00 & 46,63 & 0,12 & 0,03 & 0,02 & 0,03 & 0,00 & 0,07 & 0,01 & 53,55 & 100,67 \\
\hline PA 235_C1_py 1 & 0,00 & 0,19 & 0,00 & 45,85 & 0,06 & 0,03 & 0,00 & 0,04 & 0,00 & 0,02 & 0,03 & 54,00 & 100,21 \\
\hline PA 235_C1_py 2 & 0,01 & 0,11 & 0,00 & 46,49 & 0,08 & 0,06 & 0,00 & 0,02 & 0,00 & 0,03 & 0,01 & 53,97 & 100,82 \\
\hline PA 235_C1_py 3 & 0,02 & 0,18 & 0,00 & 46,58 & 0,07 & 0,02 & 0,01 & 0,00 & 0,00 & 0,01 & 0,09 & 53,94 & 100,97 \\
\hline PA 235_C2_py 1 & 0,01 & 0,16 & 0,00 & 46,83 & 0,09 & 0,09 & 0,00 & 0,05 & 0,00 & 0,05 & 0,00 & 53,95 & 101,23 \\
\hline PA 235_C2_py 2 & 0,00 & 0,12 & 0,00 & 47,07 & 0,09 & 0,00 & 0,02 & 0,05 & 0,00 & 0,05 & 0,02 & 54,03 & 101,48 \\
\hline PA 235_C3_py 1 & 0,02 & 0,11 & 0,03 & 46,42 & 0,12 & 0,02 & 0,00 & 0,02 & 0,00 & 0,15 & 0,02 & 54,15 & 101,06 \\
\hline PA 235_C3_py 2 & 0,00 & 0,18 & 0,00 & 46,04 & 0,09 & 0,07 & 0,09 & 0,03 & 0,00 & 0,30 & 0,00 & 54,21 & 101,00 \\
\hline PA 235_C3_py 3 & 0,00 & 0,11 & 0,00 & 46,04 & 0,12 & 0,04 & 0,00 & 0,00 & 0,00 & 0,06 & 0,00 & 53,47 & 99,86 \\
\hline PA-217A_C1_py 1 & 0,01 & 0,13 & 0,00 & 58,74 & 0,12 & 0,03 & 0,11 & 0,00 & 0,00 & 0,08 & 0,16 & 38,81 & 98,17 \\
\hline PA-217A_C1_py 2 & 0,00 & 0,15 & 0,00 & 46,33 & 0,11 & 0,00 & 0,03 & 0,02 & 0,01 & 0,06 & 0,01 & 53,44 & 100,16 \\
\hline PA-217A_C1_py 3 & 0,00 & 0,13 & 0,00 & 46,48 & 0,10 & 0,06 & 0,03 & 0,00 & 0,00 & 0,10 & 0,01 & 53,67 & 100,62 \\
\hline PA-217A_C1_py 4 & 0,00 & 0,20 & 0,00 & 57,63 & 0,05 & 0,01 & 0,00 & 0,06 & 0,00 & 0,08 & 0,17 & 38,31 & 96,54 \\
\hline PA-217A_C1_py 5 & 0,01 & 0,13 & 0,00 & 58,50 & 0,12 & 0,00 & 0,01 & 0,00 & 0,00 & 0,04 & 0,11 & 38,68 & 97,66 \\
\hline PA-217A_C2_py 1 & 0,03 & 0,23 & 0,00 & 46,54 & 0,18 & 0,00 & 0,00 & 0,00 & 0,00 & 0,00 & 0,00 & 53,74 & 100,74 \\
\hline PA 217D_C4_Py 1 & 0,00 & 0,19 & 0,00 & 45,83 & 0,12 & 0,00 & 0,03 & 0,00 & 0,00 & 0,43 & 0,01 & 52,41 & 99,04 \\
\hline PA 217D_C5_Py 1 & 0,01 & 0,11 & 0,00 & 46,51 & 0,15 & 0,00 & 0,05 & 0,05 & 0,01 & 0,02 & 0,04 & 53,13 & 100,11 \\
\hline PA 217D_C5_Py 2 & 0,00 & 0,20 & 0,00 & 46,28 & 0,18 & 0,00 & 0,00 & 0,02 & 0,00 & 0,01 & 0,04 & 53,01 & 99,73 \\
\hline PA 217D_C1_Py 1 & 0,00 & 0,06 & 0,00 & 46,76 & 0,17 & 0,02 & 0,07 & 0,04 & 0,00 & 0,08 & 0,02 & 53,33 & 100,55 \\
\hline PA 217D_C1_Py 2 & 0,02 & 0,16 & 0,00 & 46,70 & 0,10 & 0,00 & 0,04 & 0,01 & 0,00 & 0,04 & 0,00 & 52,85 & 99,92 \\
\hline PA 217D_C3_Py 1 & 0,00 & 0,15 & 0,02 & 47,70 & 0,14 & 0,02 & 0,02 & 0,02 & 0,00 & 0,05 & 0,03 & 53,81 & 101,95 \\
\hline PA 217D_C3_Py 2 & 0,01 & 0,28 & 0,00 & 46,85 & 0,13 & 0,03 & 0,00 & 0,00 & 0,00 & 0,03 & 0,00 & 54,00 & 101,37 \\
\hline PA 217D_C1_Pyr 1 & 0,02 & 0,14 & 0,00 & 59,90 & 0,10 & 0,00 & 0,00 & 0,02 & 0,03 & 0,05 & 0,13 & 39,62 & 100,05 \\
\hline PA 217D_C3_Pyr 2 & 0,01 & 0,12 & 0,00 & 48,00 & 0,10 & 0,03 & 0,00 & 0,00 & 0,03 & 0,02 & 0,03 & 53,81 & 102,19 \\
\hline PA 217D_C3_Pyr 1 & 0,01 & 0,13 & 0,00 & 59,50 & 0,08 & 0,00 & 0,00 & 0,00 & 0,09 & 0,05 & 0,62 & 38,42 & 98,90 \\
\hline
\end{tabular}

\section{Anexo 11 - TABELA DE ANÁLISE DE QUÍMICA MINERAL DAS MAGNETITAS}

\begin{tabular}{|c|c|c|c|c|c|c|c|c|c|c|c|c|c|c|c|c|c|}
\hline Amostra & $\mathrm{Na}_{2} \mathrm{O}$ & $\mathrm{MgO}$ & $\mathrm{F}$ & $\mathrm{Al}_{2} \mathrm{O}_{3}$ & $\mathrm{SiO}_{2}$ & $\mathrm{CaO}$ & $\mathrm{K}_{2} \mathrm{O}$ & $\mathrm{Cl}$ & $\mathrm{P}_{2} \mathrm{O}_{5}$ & $\mathrm{TiO}_{2}$ & $\mathrm{Cr}_{2} \mathrm{O}_{3}$ & $\mathrm{MnO}$ & $\mathrm{NiO}$ & $\mathrm{FeO}$ & $\mathrm{V}_{2} \mathrm{O}_{3}$ & $(\mathrm{OH})$ & Total \\
\hline PA220 C6 mag1 & 0,02 & 0,14 & 0,29 & 0,40 & 0,55 & 0,03 & 0,06 & 0,0 & 0,03 & 4,72 & 0,10 & 0,00 & 0,00 & 90,73 & 0,34 & 2,71 & 100,0 \\
\hline PA217A C1 mg1 & 0,09 & 0,06 & 0,24 & 2,45 & 2,74 & 0,04 & 0,20 & 0,0 & 0,01 & 0,02 & 0,00 & 0,12 & 0,04 & 87,31 & 0,06 & 6,74 & 100,0 \\
\hline PA217A C1 mg2 & 0,03 & 0,02 & 0,29 & 0,13 & 0,04 & 0,01 & 0,02 & 0,02 & 0,00 & 0,30 & 0,00 & 0,10 & 0,00 & 94,89 & 0,19 & 4,09 & 100,0 \\
\hline PA217A C1 mg3 & 0,12 & 0,03 & 0,22 & 3,14 & 4,90 & 0,25 & 0,21 & 0,03 & 0,01 & 0,52 & 0,00 & 0,17 & 0,06 & 83,83 & 0,14 & 6,48 & 100,0 \\
\hline PA217D C5 Il1 & 0,00 & 0,01 & 0,27 & 0,41 & 0,65 & 0,01 & 0,05 & 0,01 & 0,01 & 0,26 & 0,00 & 0,09 & 0,00 & 93,91 & 0,16 & 4,29 & 100,0 \\
\hline PA217D C1 Il2 & 0,00 & 0,00 & 0,35 & 0,14 & 0,03 & 0,04 & 0,02 & 0,02 & 0,06 & 0,15 & 0,00 & 0,22 & 0,04 & 95,27 & 0,09 & 3,73 & 100,0 \\
\hline PA217D C1 Il1 & 0,01 & 0,00 & 0,28 & 0,18 & 0,22 & 0,02 & 0,02 & 0,01 & 0,00 & 0,12 & 0,02 & 0,14 & 0,00 & 94,54 & 0,08 & 4,47 & 100,0 \\
\hline PA101A C1 ox 2 & 0,00 & 0,02 & 0,18 & 0,23 & 0,43 & 0,04 & 0,07 & 0,0 & 0,07 & 4,13 & 0,02 & 0,00 & 0,04 & 89,35 & 0,11 & 5,41 & 100,0 \\
\hline
\end{tabular}


"O Sistema Magmático do Depósito de Cu-Mo Tipo Pórfiro Pancho Árias, Cordilheira Oriental, Argentina"

Rafael Bellozupko Stremel

Anexo 12 - TABELA DE ANÁLISE DE QUÍMICA MINERAL DAS BIOTITAS

\begin{tabular}{|c|c|c|c|c|c|c|c|c|c|c|c|c|c|c|c|c|c|}
\hline Amostra & $\mathrm{Na}_{2} \mathrm{O}$ & $\mathrm{MgO}$ & $\mathrm{F}$ & $\mathrm{Al}_{2} \mathrm{O}_{3}$ & $\mathrm{SiO}_{2}$ & $\mathrm{CaO}$ & $\mathrm{K}_{2} \mathrm{O}$ & $\mathrm{Cl}$ & $\mathrm{P}_{2} \mathrm{O}_{5}$ & $\mathrm{TiO}_{2}$ & $\mathrm{Cr}_{2} \mathrm{O}_{3}$ & $\mathrm{MnO}$ & $\mathrm{NiO}$ & $\mathrm{FeO}$ & $\mathrm{V}_{2} \mathrm{O}_{3}$ & $(\mathrm{OH})$ & Total \\
\hline PA101 C3_Bt1 & 0,13 & 15,37 & 0,64 & 14,71 & 38,95 & 0,00 & 9,60 & 0,08 & 0,03 & 3,59 & 0,00 & 0,18 & 0,00 & 13,57 & 0,17 & 3,26 & 100,0 \\
\hline PA101_C2_Bt2 & 0,10 & 14,71 & 0,58 & 14,61 & 38,55 & 0,04 & 9,57 & 0,07 & 0,05 & 3,32 & 0,00 & 0,15 & 0,00 & 14,96 & 0,14 & 3,40 & 100,0 \\
\hline PA101A C2 bt 1 & 0,28 & 14,10 & 0,62 & 16,95 & 36,05 & 0,00 & 9,91 & 0,18 & 0,02 & 2,93 & 0,03 & 0,15 & 0,01 & 15,45 & 0,16 & 3,47 & 100,0 \\
\hline PA101A C4 bt1 & 0,23 & 15,57 & 0,88 & 16,11 & 37,60 & 0,00 & 9,73 & 0,15 & 0,00 & 3,34 & 0,01 & 0,17 & 0,00 & 12,30 & 0,21 & 4,12 & 100,0 \\
\hline PA237_C2_Bt1 & 0,10 & 14,47 & 0,42 & 16,65 & 37,00 & 0,03 & 9,98 & 0,09 & 0,04 & 2,30 & 0,00 & 0,19 & 0,00 & 13,76 & 0,12 & 5,06 & 100,0 \\
\hline PA237_C2_Bt1 & 0,11 & 13,82 & 0,38 & 16,47 & 37,36 & 0,09 & 9,64 & 0,12 & 0,00 & 4,24 & 0,00 & 0,20 & 0,03 & 14,21 & 0,11 & 3,43 & 100,0 \\
\hline PA237_C2Bt 2 & 0,20 & 13,56 & 0,41 & 16,36 & 37,21 & 0,07 & 9,84 & 0,14 & 0,02 & 3,01 & 0,00 & 0,09 & 0,01 & 14,39 & 0,14 & 4,77 & 100,0 \\
\hline PA237_C2_Bt2 & 0,08 & 14,40 & 0,55 & 16,42 & 38,34 & 0,04 & 9,71 & 0,10 & 0,01 & 2,81 & 0,05 & 0,09 & 0,00 & 12,97 & 0,14 & 4,56 & 100,0 \\
\hline PA237_C1_Bt3 & 0,17 & 11,97 & 0,54 & 13,87 & 33,23 & 0,00 & 8,06 & 0,13 & 0,00 & 3,33 & 0,00 & 0,04 & 0,02 & 13,46 & 0,01 & 15,42 & 100,0 \\
\hline PA237_C1_Bt3 & 0,16 & 12,96 & 0,44 & 16,43 & 37,75 & 0,00 & 10,1 & 0,12 & 0,07 & 2,41 & 0,00 & 0,15 & 0,03 & 16,33 & 0,08 & 3,23 & 100,0 \\
\hline PA102_C5_bt1 & 0,36 & 14,17 & 0,85 & 14,43 & 35,97 & 0,04 & 9,52 & 0,22 & 0,00 & 4,57 & 0,00 & 0,09 & 0,01 & 16,69 & 0,04 & 3,47 & 100,0 \\
\hline PA102_C5_bt2 & 0,35 & 13,34 & 1,00 & 13,59 & 35,51 & 0,05 & 9,38 & 0,24 & 0,00 & 4,94 & 0,05 & 0,11 & 0,04 & 17,79 & 0,10 & 4,01 & 100,0 \\
\hline PA102_C5_bt3 & 0,24 & 14,18 & 1,47 & 14,17 & 36,58 & 0,00 & 9,74 & 0,25 & 0,00 & 5,44 & 0,01 & 0,15 & 0,02 & 15,90 & 0,10 & 2,43 & 100,0 \\
\hline PA102_C2_bt1 & 0,45 & 15,55 & 1,18 & 13,93 & 36,58 & 0,03 & 9,48 & 0,23 & 0,10 & 4,45 & 0,00 & 0,11 & 0,00 & 14,88 & 0,11 & 3,48 & 100,0 \\
\hline PA102_C2_bt2 & 0,57 & 15,80 & 1,28 & 13,84 & 36,53 & 0,01 & 9,43 & 0,20 & 0,00 & 3,86 & 0,13 & 0,12 & 0,00 & 14,98 & 0,03 & 3,81 & 100,0 \\
\hline PA102_C1_bt1 & 0,39 & 14,03 & 1,09 & 14,19 & 36,17 & 0,02 & 9,47 & 0,22 & 0,01 & 5,10 & 0,11 & 0,10 & 0,03 & 16,27 & 0,05 & 3,26 & 100,0 \\
\hline PA102_C1_bt2 & 0,39 & 15,16 & 1,78 & 14,20 & 36,85 & 0,00 & 9,75 & 0,23 & 0,03 & 5,10 & 0,03 & 0,10 & 0,00 & 15,06 & 0,13 & 1,99 & 100,0 \\
\hline PA102_C1_bt3 & 0,10 & 13,38 & 1,37 & 13,99 & 36,08 & 0,07 & 9,76 & 0,20 & 0,00 & 4,85 & 0,00 & 0,05 & 0,05 & 16,73 & 0,15 & 3,84 & 100,0 \\
\hline PA102_C1_bt4 & 0,25 & 13,53 & 1,54 & 13,27 & 35,76 & 0,05 & 9,15 & 0,23 & 0,00 & 4,37 & 0,00 & 0,18 & 0,00 & 19,17 & 0,05 & 3,15 & 100,0 \\
\hline PA105 BC6bt 1 & 0,19 & 10,61 & 0,36 & 16,46 & 35,82 & 0,04 & 9,52 & 0,22 & 0,01 & 3,77 & 0,09 & 0,15 & 0,00 & 20,65 & 0,16 & 2,15 & 100,0 \\
\hline PA105B C6bt 2 & 0,22 & 11,03 & 0,45 & 15,52 & 37,01 & 0,05 & 9,36 & 0,23 & 0,00 & 2,31 & 0,06 & 0,15 & 0,01 & 19,81 & 0,08 & 3,97 & 100,0 \\
\hline PA105B C3bt 1 & 0,21 & 10,59 & 0,31 & 16,39 & 34,97 & 0,06 & 9,71 & 0,27 & 0,02 & 3,49 & 0,00 & 0,30 & 0,00 & 20,11 & 0,07 & 3,70 & 100,0 \\
\hline PA105B C3bt 2 & 0,18 & 10,48 & 0,29 & 16,19 & 35,94 & 0,08 & 9,77 & 0,25 & 0,03 & 2,48 & 0,00 & 0,12 & 0,00 & 20,77 & 0,17 & 3,45 & 100,0 \\
\hline PA105B C1bt 1 & 0,26 & 11,90 & 0,48 & 16,35 & 35,88 & 0,02 & 9,86 & 0,20 & 0,00 & 3,49 & 0,06 & 0,22 & 0,00 & 18,04 & 0,09 & 3,42 & 100,0 \\
\hline PA101B C1bt 2 & 0,25 & 12,24 & 0,52 & 16,17 & 36,54 & 0,00 & 9,85 & 0,21 & 0,00 & 3,11 & 0,01 & 0,18 & 0,00 & 17,30 & 0,04 & 3,84 & 100,0 \\
\hline PA201_C6Bt 1 & 0,13 & 12,73 & 0,28 & 13,67 & 36,18 & 0,04 & 9,21 & 0,21 & 0,00 & 4,03 & 0,00 & 0,42 & 0,00 & 18,40 & 0,11 & 4,77 & 100,0 \\
\hline PA201_C6Bt 2 & 0,00 & 12,16 & 0,34 & 14,00 & 30,98 & 3,91 & 1,51 & 0,04 & 0,00 & 5,20 & 0,03 & 0,52 & 0,04 & 19,88 & 0,12 & 11,41 & 100,0 \\
\hline PA201_C8Bt 1 & 0,00 & 15,93 & 0,0 & 16,09 & 30,39 & 0,24 & 0,09 & 0,02 & 0,05 & 0,02 & 0,00 & 0,60 & 0,00 & 23,79 & 0,02 & 12,78 & 100,0 \\
\hline PA201_C8Bt 2 & 0,00 & 17,85 & 0,03 & 16,31 & 28,84 & 0,64 & 0,00 & 0,00 & 0,00 & 0,65 & 0,01 & 0,82 & 0,04 & 23,70 & 0,02 & 11,11 & 100,0 \\
\hline PA201 C11Bt 1 & 0,05 & 15,18 & 0,09 & 16,06 & 31,68 & 0,10 & 2,99 & 0,06 & 0,01 & 2,11 & 0,00 & 0,62 & 0,03 & 23,07 & 0,04 & 7,96 & 100,0 \\
\hline PA201 C11Bt 2 & 0,09 & 12,83 & 0,25 & 13,92 & 36,37 & 0,00 & 9,55 & 0,11 & 0,02 & 4,17 & 0,00 & 0,60 & 0,00 & 18,45 & 0,09 & 3,69 & 100,0 \\
\hline PA201 C11Bt 3 & 0,16 & 13,14 & 0,21 & 13,68 & 32,66 & 0,49 & 4,32 & 0,10 & 0,03 & 3,33 & 0,03 & 0,44 & 0,04 & 19,02 & 0,12 & 12,35 & 100,0 \\
\hline
\end{tabular}


"O Sistema Magmático do Depósito de Cu-Mo Tipo Pórfiro Pancho Árias, Cordilheira Oriental, Argentina" Rafael Bellozupko Stremel

\begin{tabular}{|c|c|c|c|c|c|c|c|c|c|c|c|c|c|c|c|c|c|c|}
\hline Amostra & $\mathrm{SiO}_{2}$ & $\mathrm{TiO}_{2}$ & $\mathrm{Al}_{2} \mathrm{O}_{3}$ & $\mathrm{FeO}$ & $\mathrm{MnO}$ & $\mathrm{MgO}$ & $\mathrm{CaO}$ & $\mathrm{Na}_{2} \mathrm{O}$ & $\mathrm{K} 2 \mathrm{O}$ & $\mathrm{F}$ & $\mathrm{Cl}$ & $\mathrm{Cr}_{2} \mathrm{O}_{3}$ & $\mathrm{NiO}$ & Li2O* & $\mathrm{H} 2 \mathrm{O}^{*}$ & Subtotal & $\mathrm{O}=\mathrm{F}, \mathrm{Cl}$ & Total \\
\hline PA-237_C2_Bt 1 B1 & 37,0 & 2,30 & 16,65 & 13,76 & 0,19 & 14,47 & 0,03 & 0,10 & 9,98 & 0,42 & 0,09 & 0,00 & 0,00 & 1,07 & 3,83 & 99,88 & 0,20 & 99,68 \\
\hline PA-237_C2_Bt 1 B2 & 37,4 & 4,24 & 16,47 & 14,21 & 0,20 & 13,82 & 0,09 & 0,11 & 9,64 & 0,38 & 0,12 & 0,00 & 0,03 & 1,17 & 3,92 & 101,74 & 0,19 & 101,55 \\
\hline PA-237_C2_Bt 2 B1 & 37,2 & 3,01 & 16,36 & 14,39 & 0,09 & 13,56 & 0,07 & 0,20 & 9,84 & 0,41 & 0,14 & 0,00 & 0,01 & 1,13 & 3,83 & 100,23 & 0,20 & 100,02 \\
\hline PA-237_C2_Bt 2 B2 & 38,3 & 2,81 & 16,42 & 12,97 & 0,09 & 14,40 & 0,04 & 0,08 & 9,71 & 0,55 & 0,10 & 0,05 & 0,00 & 1,45 & 3,85 & 100,85 & 0,25 & 100,60 \\
\hline PA-237_C1_Bt 3 B1 & 33,2 & 3,33 & 13,87 & 13,46 & 0,04 & 11,97 & 0,00 & 0,17 & 8,06 & 0,54 & 0,13 & 0,00 & 0,02 & 0,00 & 3,27 & 88,10 & 0,25 & 87,85 \\
\hline PA-237_C1_Bt 3 B2 & 37,6 & 2,41 & 16,43 & 16,33 & 0,15 & 12,96 & 0,00 & 0,16 & 10,05 & 0,44 & 0,12 & 0,00 & 0,03 & 1,28 & 3,86 & 101,98 & 0,21 & 101,76 \\
\hline PA-102_C5_bt b1 & 36 & 4,57 & 14,43 & 16,69 & 0,09 & 14,17 & 0,04 & 0,36 & 9,52 & 0,85 & 0,22 & 0,00 & 0,01 & 0,77 & 3,56 & 101,23 & 0,41 & 100,83 \\
\hline PA-102_C5_bt b2 & 35,5 & 4,94 & 13,59 & 17,79 & 0,11 & 13,34 & 0,05 & 0,35 & 9,38 & 1,00 & 0,24 & 0,05 & 0,04 & 0,64 & 3,42 & 100,43 & 0,47 & 99,95 \\
\hline PA-102_C5_bt b3 & 36,6 & 5,44 & 14,17 & 15,90 & 0,15 & 14,18 & 0,00 & 0,24 & 9,74 & 1,47 & 0,25 & 0,01 & 0,02 & 0,95 & 3,31 & 102,40 & 0,67 & 101,73 \\
\hline PA-102_C2_bt b1 & 36,6 & 4,45 & 13,93 & 14,88 & 0,11 & 15,55 & 0,03 & 0,45 & 9,48 & 1,18 & 0,23 & 0,00 & 0,00 & 0,95 & 3,43 & 101,23 & 0,55 & 100,68 \\
\hline PA-102_C2_bt b2 & 36,5 & 3,86 & 13,84 & 14,98 & 0,12 & 15,80 & 0,01 & 0,57 & 9,43 & 1,28 & 0,20 & 0,13 & 0,00 & 0,93 & 3,38 & 101,06 & 0,58 & 100,47 \\
\hline PA-102_C1_bt b1 & 36,2 & 5,10 & 14,19 & 16,27 & 0,10 & 14,03 & 0,02 & 0,39 & 9,47 & 1,09 & 0,22 & 0,11 & 0,03 & 0,83 & 3,46 & 101,48 & 0,51 & 100,97 \\
\hline PA-102_C1_bt b2 & 36,9 & 5,10 & 14,20 & 15,06 & 0,10 & 15,16 & 0,00 & 0,39 & 9,75 & 1,78 & 0,23 & 0,03 & 0,00 & 1,02 & 3,20 & 102,88 & 0,80 & 102,08 \\
\hline PA-102_C1_bt b3 & 36,1 & 4,85 & 13,99 & 16,73 & 0,05 & 13,38 & 0,07 & 0,10 & 9,76 & 1,37 & 0,20 & 0,00 & 0,05 & 0,80 & 3,29 & 100,72 & 0,62 & 100,10 \\
\hline PA-102_C1_bt b4 & 35,8 & 4,37 & 13,27 & 19,17 & 0,18 & 13,53 & 0,05 & 0,25 & 9,15 & 1,54 & 0,23 & 0,00 & 0,00 & 0,71 & 3,18 & 101,38 & 0,70 & 100,69 \\
\hline PA-105 B_C1 bt 1 & 35,9 & 3,49 & 16,35 & 18,04 & 0,22 & 11,90 & 0,02 & 0,26 & 9,86 & 0,48 & 0,20 & 0,06 & 0,00 & 0,75 & 3,73 & 101,22 & 0,25 & 100,97 \\
\hline PA-105 B_C1 bt 2 & 36,5 & 3,11 & 16,17 & 17,30 & 0,18 & 12,24 & 0,00 & 0,25 & 9,85 & 0,52 & 0,21 & 0,01 & 0,00 & 0,94 & 3,73 & 101,05 & 0,27 & 100,78 \\
\hline PA-201_C6_Bt 1 & 36,9 & 4,03 & 13,67 & 18,40 & 0,42 & 12,73 & 0,04 & 0,13 & 9,21 & 0,28 & 0,21 & 0,00 & 0,00 & 0,83 & 3,77 & 99,88 & 0,16 & 99,72 \\
\hline PA-201_C6_Bt 2 & 31 & 5,20 & 14,00 & 19,88 & 0,52 & 12,16 & 3,91 & 0,00 & 1,51 & 0,34 & 0,04 & 0,03 & 0,04 & 0,00 & 3,51 & 92,13 & 0,15 & 91,98 \\
\hline PA-201_C8_Bt 1 & 30,4 & 0,02 & 16,09 & 23,79 & 0,60 & 15,93 & 0,24 & 0,00 & 0,09 & 0,00 & 0,02 & 0,00 & 0,00 & 0,00 & 3,64 & & 0,00 & 90,79 \\
\hline PA-201_C8_Bt 2 & 28,8 & 0,65 & 16,31 & 23,70 & 0,82 & 17,85 & 0,64 & 0,00 & 0,00 & 0,03 & 0,00 & 0,01 & 0,04 & 0,00 & 3,67 & 92,56 & 0,01 & 92,55 \\
\hline PA-201_C11_Bt 1 & 31,7 & 2,11 & 16,06 & 23,07 & 0,62 & 15,18 & 0,10 & 0,05 & 2,99 & 0,09 & 0,06 & 0,00 & 0,03 & 0,00 & 3,74 & 95,78 & 0,05 & 95,73 \\
\hline PA-201_C11_Bt 2 & 36,4 & 4,17 & 13,92 & 18,45 & 0,60 & 12,83 & 0,00 & 0,09 & 9,55 & 0,25 & 0,11 & 0,00 & 0,00 & 0,89 & 3,85 & 101,07 & 0,13 & 100,94 \\
\hline PA-201_C11_Bt 3 & 32,7 & 3,33 & 13,68 & 19,02 & 0,44 & 13,14 & 0,49 & 0,16 & 4,32 & 0,21 & 0,10 & 0,03 & 0,04 & 0,00 & 3,52 & & 0,11 & 91,03 \\
\hline PA-101_C3_Bt 1 & 38,9 & 3,59 & 14,71 & 13,57 & 0,18 & 15,37 & 0,00 & 0,13 & 9,60 & 0,64 & 0,08 & 0,00 & 0,00 & 1,63 & 3,85 & 102,30 & 0,29 & 102,01 \\
\hline PA-101_C2_Bt 2 & 38,6 & 3,32 & 14,61 & 14,96 & 0,15 & 14,71 & 0,04 & 0,10 & 9,57 & 0,58 & 0,07 & 0,00 & 0,00 & 1,51 & 3,85 & 102,02 & 0,26 & 101,76 \\
\hline PA-101A_C2 bt 1 & 36,1 & 2,93 & 16,95 & 15,45 & 0,15 & 14,10 & 0,00 & 0,28 & 9,91 & 0,62 & 0,18 & 0,03 & 0,01 & 0,79 & 3,72 & 101,16 & 0,30 & 100,86 \\
\hline PA-101A_C4 bt 1 & 37,6 & 3,34 & 16,11 & 12,30 & 0,17 & 15,57 & 0,00 & 0,23 & 9,73 & 0,88 & 0,15 & 0,01 & 0,00 & 1,24 & 3,67 & 100,98 & 0,40 & 100,58 \\
\hline PA-105 B_C6 bt 1 & 35,8 & 3,77 & 16,46 & 20,65 & 0,15 & 10,61 & 0,04 & 0,19 & 9,52 & 0,36 & 0,22 & 0,09 & 0,00 & 0,73 & 3,80 & 102,41 & 0,20 & 102,21 \\
\hline PA-105 B_C6 bt 2 & 37,0 & 2,31 & 15,52 & 19,81 & 0,15 & 11,03 & 0,05 & 0,22 & 9,36 & 0,45 & 0,23 & 0,06 & 0,01 & 1,07 & 3,72 & 100,99 & 0,24 & 100,75 \\
\hline PA-105 B_C3 bt 1 & 35 & 3,49 & 16,39 & 20,11 & 0,30 & 10,59 & 0,06 & 0,21 & 9,71 & 0,31 & 0,27 & 0,00 & 0,00 & 0,48 & 3,72 & 100,60 & 0,19 & 100,41 \\
\hline PA-105 B_C3 bt 2 & 35,9 & 2,48 & 16,19 & 20,77 & 0,12 & 10,48 & 0,08 & 0,18 & 9,77 & 0,29 & 0,25 & 0,00 & 0,00 & 0,76 & 3,76 & 101,06 & 0,18 & 100,88 \\
\hline
\end{tabular}

